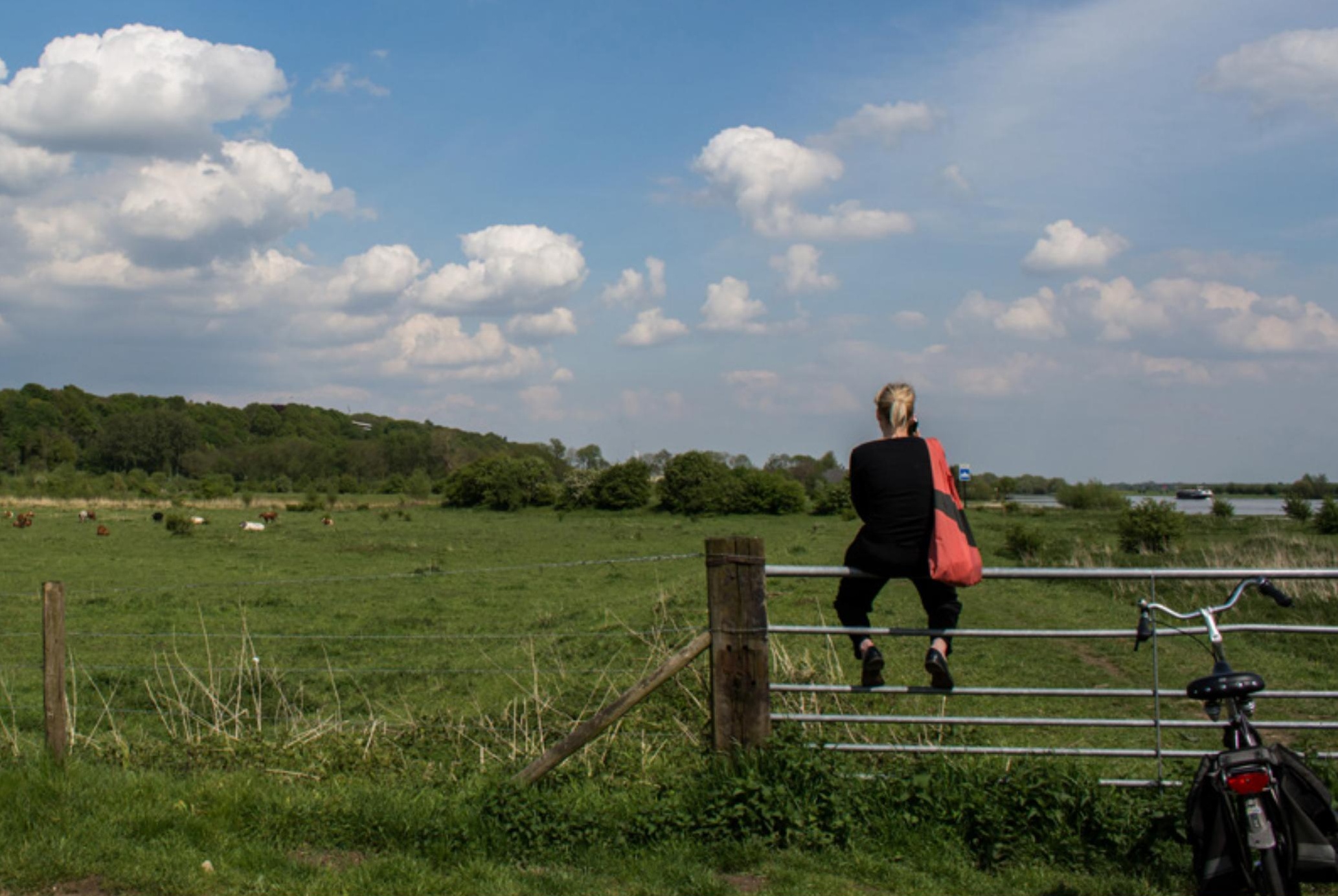

\title{
Maatschappelijk draagvlak voor natuurbeleid en betrokkenheid bij natuur in 2017
}



Maatschappelijk draagvlak voor natuurbeleid en betrokkenheid bij natuur in 2017 
Dit Technical report is gemaakt conform het Kwaliteitsmanagementsysteem (KMS) van de unit Wettelijke Onderzoekstaken Natuur \& Milieu, onderdeel van Wageningen University \& Research.

De WOT Natuur \& Milieu voert wettelijke onderzoekstaken uit op het beleidsterrein natuur en milieu. Deze taken worden uitgevoerd om een wettelijke verantwoordelijkheid van de minister van Landbouw, Natuur en Voedselkwaliteit te ondersteunen. De WOT Natuur \& Milieu werkt aan producten van het Planbureau voor de Leefomgeving, zoals de Balans van de Leefomgeving en de Natuurverkenning. Verder brengen we voor het ministerie van Landbouw, Natuur en Voedselkwaliteit adviezen uit over (toelating van) meststoffen en bestrijdingsmiddelen, en zorgen we voor informatie voor Europese rapportageverplichtingen over biodiversiteit.

De reeks 'WOt-technical reports bevat onderzoeksresultaten van projecten die kennisorganisaties voor de unit Wettelijke Onderzoekstaken Natuur \& Milieu hebben uitgevoerd.

Dit onderzoek is uitgevoerd in opdracht van het Planbureau voor de Leefomgeving (PBL). Het PBL is een inhoudelijk onafhankelijk onderzoeksinstituut op het gebied van milieu, natuur en ruimte, zoals gewaarborgd in de Aanwijzingen voor de Planbureaus, Staatscourant 3200, 21 februari 2012.

Dit onderzoeksrapport draagt bij aan de kennis die verwerkt wordt in meer beleidsgerichte publicaties zoals Natuurverkenning, Balans van de Leefomgeving en andere thematische verkenningen.

Het onderzoek is gefinancierd door het Ministerie van Landbouw, Natuur en Voedselkwaliteit (LNV). 


\section{Maatschappelijk draagvlak voor natuurbeleid en betrokkenheid bij natuur in 2017}

T.A. de Boer \& F.L. Langers 


\section{Referaat}

Boer, T.A. de en F.L. Langers (2017). Maatschappelijk draagvlak voor natuurbeleid en betrokkenheid bij natuur in 2017. Wageningen, Wettelijke Onderzoekstaken Natuur \& Milieu, WUR. WOt-technical report 102. 124 blz. 50 fig.; 19 tab.; 16 ref.; 5 bijl.

In dit rapport staan de resultaten van de longitudinale studie naar maatschappelijk draagvlak voor natuur. In 2017 is voor de vijfde keer in twintig jaar een enquête gehouden over dit onderwerp onder een representatieve groep Nederlanders. Uit deze longitudinale studie blijkt dat de Nederlandse bevolking natuurbehoud belangrijk vindt, maar is ambivalent over het economische belang van natuur. De aandacht voor natuur vinden zij terecht. Het publiek vindt de natuur al jaren geen prioritair beleidsthema, maar men ziet de overheid wel als hoofdverantwoordelijke voor natuur. Zij vinden zichzelf, natuurorganisaties en (landbouw) bedrijven wel in belangrijke mate medeverantwoordelijk. Het draagvlak voor maatregelen om natuur te beschermen is groot. De bevolking is vooral betrokken bij natuur door laagdrempelige activiteiten als het bezoeken van natuur en groen, nestkastjes ophangen, afval opruimen, groen stemmen en een handtekening zetten voor natuur. Het publiek is minder actief als het gaat om onderhoud van natuur- en landschap, natuureducatie, buurtoverleg bijwonen of meedoen aan groene burgerinitiatieven.

Trefwoorden: maatschappelijk draagvlak, enquête, monitoring, natuur, natuurbeleid, burgerinitiatieven, natuurbeelden, longitudinaal, betrokkenheid

\section{Abstract}

Boer, T.A. de en F.L. Langers (2017). Public support for nature policy and involvement with nature in 2017. Statutory Research Tasks Unit for Nature \& the Environment (WOT Natuur \& Milieu), WOt-technical report 102. 124 p.; 50 figs; 19 tabs; 16 refs; 5 annexes.

This report presents the results of the longitudinal study of public support for nature. In 2017 a questionnaire survey on this topic was held among a representative sample of the Dutch population for the fifth time in twenty years. This longitudinal study indicates that the Dutch population think nature is important, but are ambivalent about the economic importance of nature. They believe the attention given to nature is justified. For many years the public have thought that nature should not be a priority for government policy, but people do think the main responsibility for nature lies with government. They also think that they themselves, nature conservation organisations, agricultural firms and industry share much of the responsibility. There is a great deal of support for measures to conserve nature. People's involvement with nature is limited mainly to low-threshold activities such as visiting nature reserves and the countryside, hanging up nesting boxes, clearing away rubbish, voting for green political parties and signing petitions. The public is less active in habitat maintenance and landscape restoration work, nature education, attending neighbourhood meetings or taking part in green citizens' initiatives.

Keywords: public support, survey, monitoring, nature, nature policy, citizens' initiatives, conceptions of nature, longitudinal, involvement

\section{(C) 2017 Wageningen Environmental Research}

Postbus 47, 6700 AA Wageningen

Tel: (0317) 480700 ; e-mail: info.alterra@wur.nl

De reeks WOt-technical reports is een uitgave van de unit Wettelijke Onderzoekstaken Natuur \& Milieu, onderdeel van Wageningen UR. Dit report is verkrijgbaar bij het secretariaat. De publicatie is ook te downloaden via www.wur.nl/wotnatuurenmilieu

Wettelijke Onderzoekstaken Natuur \& Milieu, Postbus 47, 6700 AA Wageningen

Tel: (0317) 4854 71; e-mail: info.wnm@wur.nl; Internet: www.wur.nl/wotnatuurenmilieu.

Alle rechten voorbehouden. Niets uit deze uitgave mag worden verveelvoudigd en/of openbaar gemaakt door middel van druk, fotokopie, microfilm of op welke andere wijze ook zonder voorafgaande schriftelijke toestemming van de uitgever. De uitgever aanvaardt geen aansprakelijkheid voor eventuele schade voortvloeiend uit het gebruik van de resultaten van dit onderzoek of de toepassing van de adviezen. 


\section{Woord vooraf}

Volgens de Rijksnatuurvisie 2014 'Natuurlijk verder' streeft de rijksoverheid naar natuur midden in de samenleving. Daarbij blijkt de samenleving zelf steeds meer in staat om natuurdoelen dichterbij te brengen, en het de overheid past om zich terughoudend op te stellen en om vooral een voorwaardenscheppende en stimulerende rol op zich te nemen. De veronderstelling achter het beleid is dat betrokkenheid van de samenleving de natuur ten goede zal komen. De overheid wil dan ook graag weten wat het maatschappelijk draagvlak voor beleid is en in hoeverre burgers betrokken zijn bij natuur.

In 2017 hebben onderzoekers van Wageningen Environmental Research voor de vijfde keer het maatschappelijk draagvlak voor natuur, natuurbeleid en betrokkenheid gepeild. Sinds 1996 wordt ongeveer eens in de vijf jaar een meting gehouden onder een representatieve groep Nederlanders. Naast de landelijke cijfers zijn voor het eerst ook provinciale resultaten vermeld. Uit de resultaten blijkt dat er sprake is van een herstel in het maatschappelijk draagvlak; na een dip in 2006-2013 is men in 2017 weer positiever.

Voor beleidsmakers en politici is deze monitoring belangrijk. Deze studie biedt inzicht in de waardering van natuurbeleid en de betrokkenheid bij natuur en landschap, en zet deze voor zover mogelijk in een trend. Deze inzichten helpen om het beleid verder vorm te geven.

Deze studie is uitgevoerd in opdracht van de WOT Natuur \& Milieu en is begeleid door het Planbureau voor de Leefomgeving. Het onderzoek is gefinancierd door het ministerie van Landbouw, Natuur en Voedselkwaliteit (tot medio 2017 ministerie van Economische Zaken). Bij het realiseren van deze studie is de inzet en openheid van respondenten van groot belang, waarvoor veel dank.

Wij hebben zeer prettig samengewerkt met Tineke de Boer en Fransje Langers, ons eerste aanspreekpunten voor dit rapport. Eveneens dank aan Martin Goossen die dit onderzoek mede heeft begeleid vanuit Wageningen Environmental Research.

Hendrien Bredenoord

Planbureau voor de Leefomgeving, Den Haag 



\section{Inhoud}

2 Theoretische verkenning van draagvlak

$\begin{array}{lll}2.1 & \text { Definities en indicatoren van draagvlak in de vorige studies } & 15\end{array}$

2.2 Definitie en indicatoren van draagvlak in deze studie 15

3 Onderzoeksmethode $r$

$\begin{array}{lll}3.1 & \text { Vragenlijst } & 19\end{array}$

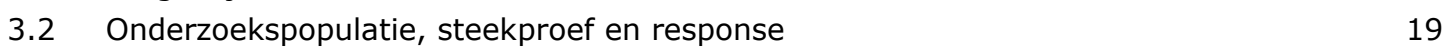

$\begin{array}{lll}3.3 & \text { Analyse } & 20\end{array}$

$4 \quad$ Belang van natuurbehoud $\quad 23$

$\begin{array}{lll}4.1 & \text { Inleiding } & 23\end{array}$

$\begin{array}{lll}4.2 & \text { Belang van natuurbehoud } & 23\end{array}$

4.2.1 Landelijk beeld $\quad 23$

$\begin{array}{ll}4.2 .2 \text { Provincies } & 23\end{array}$

4.2.3 Vergelijking met eerdere jaren $\quad 26$

$\begin{array}{lll}4.3 & \text { Dilemma's natuur en economie } & 27\end{array}$

$\begin{array}{ll}\text { 4.3.1 Landelijk beeld } & 27\end{array}$

$\begin{array}{ll}\text { 4.3.2 Vergelijking met eerdere jaren } & 27\end{array}$

$\begin{array}{lll}4.4 & \text { Waarom vinden mensen natuur belangrijk? } & 28\end{array}$

4.4.1 Landelijk beeld $\quad 28$

$\begin{array}{ll}\text { 4.4.2 Provincies } & 29\end{array}$

$\begin{array}{lll}4.5 & \text { Gewenste omgang met de natuur } & 31\end{array}$

4.5.1 Landelijk beeld 31

$\begin{array}{ll}4.5 .2 \text { Vergelijking met eerdere jaren } & 31\end{array}$

$\begin{array}{lll}4.6 & \text { Waardering van de hoeveelheid natuur } & 33\end{array}$

4.6.1 Landelijk beeld $\quad 33$

$\begin{array}{lll}4.6 .2 & \text { Provincies } & 33\end{array}$

$\begin{array}{ll}4.6 .3 \text { Vergelijking met eerdere jaren } & 34\end{array}$

$5 \quad$ Steun voor natuurbeleid $\quad 37$

$\begin{array}{lll}5.1 & \text { Inleiding } & 37\end{array}$

$\begin{array}{lll}5.2 & \text { Belang van natuurbeleid t.o.v. andere beleidsvelden } & 37\end{array}$

$\begin{array}{ll}\text { 5.2.1 Landelijk beeld } & 37\end{array}$

5.2.2 Vergelijking met eerdere jaren $\quad 38$

5.3 Welke actoren zijn verantwoordelijk voor natuur in natuurgebieden, op het platteland en

$\begin{array}{ll}\text { in de stad? } & 38\end{array}$

5.3.1 Landelijk beeld $\quad 38$

5.3.2 Vergelijking met eerdere jaren $\quad 40$

$\begin{array}{lll}5.4 & \text { Belang van maatregelen om natuur te beschermen } & 43\end{array}$

$\begin{array}{ll}\text { 5.4.1 Landelijk beeld } & 43\end{array}$

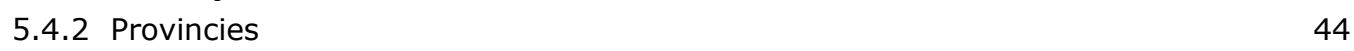

5.4.3 Vergelijking met eerdere jaren 46 
$\begin{array}{llr}6.1 & \text { Inleiding } & 49\end{array}$

$\begin{array}{lll}6.2 & \text { Potentiële betrokkenheid bij de natuur } & 49\end{array}$

6.2.1 Landelijk beeld $\quad 49$

$\begin{array}{ll}6.2 .2 \text { Provincies } & 50\end{array}$

$\begin{array}{lll}6.3 & \text { Burger als gebruiker } & 54\end{array}$

6.3.1 Landelijk beeld: bezoek aan stadsgroen, platteland en natuurgebieden $\quad 54$

6.3.2 Provincies: bezoek aan stadsgroen, platteland en natuurgebieden $\quad 54$

6.3.3 Vergelijking met eerdere jaren $\quad 56$

6.3.4 Landelijk beeld: gebruik van informatiebronnen over natuur $\quad 56$

6.3.5 Provincies: gebruik van informatiebronnen over natuur $\quad 57$

6.3.6 Vergelijking met eerdere jaren $\quad 58$

$\begin{array}{lll}6.4 & \text { Burger als beschermer } & 58\end{array}$

6.4.1 Landelijk beeld: ondernomen activiteiten voor natuur en landschap $\quad 58$

6.4.2 Provincies: ondernomen activiteiten voor natuur en landschap 59

$\begin{array}{ll}6.4 .3 \text { Vergelijking met eerdere jaren } & 60\end{array}$

6.4.4 Landelijk beeld: lidmaatschap natuurorganisaties $\quad 60$

6.4.5 Provincies: lidmaatschap natuurorganisaties $\quad 60$

6.4.6 Vergelijking met eerdere jaren $\quad 61$

6.4.7 Landelijk beeld: financiële bijdrage aan natuur $\quad 62$

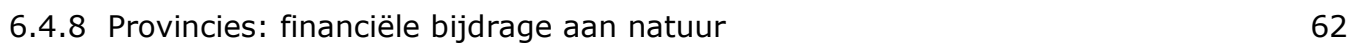

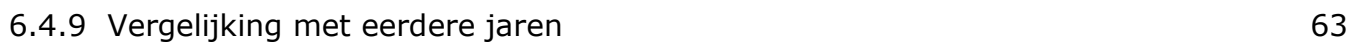

$\begin{array}{lll}6.5 & \text { Burger als medebeslisser } & 64\end{array}$

6.5.1 Landelijk beeld: ondernomen activiteiten om besluitvorming over natuur te beïnvloeden

6.5.2 Provincies: ondernomen activiteiten om besluitvorming over natuur te beïnvloeden

6.5.3 Vergelijking met eerdere jaren

6.5.4 Landelijk beeld: kennis van burgerinitiatieven op het gebied van natuur en landschap

6.5.5 Provincies: kennis van burgerinitiatieven op het gebied van natuur en landschap 66

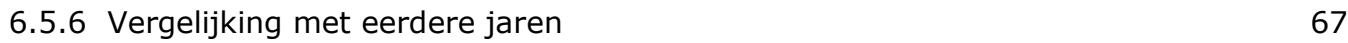

6.5.7 Landelijk beeld: soort initiatieven die men kent $\quad 68$

$\begin{array}{ll}\text { 6.5.8 Provincies: soort initiatieven die men kent } & 68\end{array}$

6.5.9 Landelijk beeld: betrokkenheid bij burgerinitiatieven 68

6.5.10Provincies: betrokkenheid bij burgerinitiatieven $\quad 69$

$\begin{array}{ll}\text { 6.5.11Vergelijking met eerdere jaren } & 69\end{array}$

$\begin{array}{lll}6.6 & \text { Een indeling van burgers naar betrokkenheid bij natuur } & 71\end{array}$

$\begin{array}{ll}\text { 6.6.1 Landelijk beeld } & 71 \\ \end{array}$

$\begin{array}{ll}\text { 6.6.2 Vergelijking met eerdere jaren } & 73\end{array}$

$\begin{array}{llr}7 & \text { Conclusies } & 75\end{array}$

$\begin{array}{lll}7.1 & \text { Kernboodschappen } & 75\end{array}$

$\begin{array}{lll}7.2 & \text { Het draagvlak voor natuur in } 2017 & 76\end{array}$

$\begin{array}{lll}7.3 & \text { Trends in het maatschappelijk draagvlak voor natuur } & 78\end{array}$

$\begin{array}{lr}\text { Literatuur } & \mathbf{8 1}\end{array}$

$\begin{array}{lr}\text { Verantwoording } & 83\end{array}$

Bijlage 1 Veranderingen in de vragenlijst $2017-2013$

Bijlage 2 Vragenlijst Draagvlak voor natuur en natuurbeleid 201791

Bijlage 3 Tabellen met significante verschillen op basis van sociaal-demografische kenmerken 97

Bijlage 4 Tabellen met significante verschillen op basis van verschuivingen in de tijd 115

$\begin{array}{llr}\text { Bijlage } 5 & \text { Segmentatie burgerbetrokkenheid bij natuur } & 119\end{array}$ 


\section{Samenvatting}

In 2017 is voor de vijfde keer het maatschappelijk draagvlak voor natuur, natuurbeleid en betrokkenheid gemeten. Sinds 1996 wordt ongeveer eens in de vijf jaar een peiling gehouden in de vorm van een enquête onder een representatieve groep Nederlanders. De overheid wil hiermee meten wat de mening is van de bevolking over de natuur en het natuurbeleid en in hoeverre mensen betrokken zijn bij de natuur. Daarnaast wil men weten of hierin in de loop der jaren veranderingen zijn opgetreden. Een monitoringsonderzoek maakt het mogelijk om deze trends in het draagvlak te beschrijven.

\section{Belangrijkste resultaten}

Het maatschappelijk besef van het belang van natuurbehoud is substantieel en is in 2017, na een daling in 2013, weer toegenomen. Dit betekent dat een groter aandeel van de burgers vindt dat de aandacht voor natuur niet overdreven is, we ons terecht zorgen maken over de toekomst van de natuur en de overheid niet te weinig geld uitgeeft aan natuurbehoud. Over het economische belang van natuur zijn de meningen verdeeld. Enerzijds vind één op de drie Nederlanders dat natuur geen belemmering mag zijn voor economische vooruitgang en anderzijds kiezen burgers in hun woonomgeving vaker voor het natuurbelang dan het economische belang. Men geeft de voorkeur aan meer groen boven meer winkels of woningen en rekeningrijden boven extra wegen. Ook vinden burgers dat geld verdienen met natuur de minst belangrijke functie van natuur is.

De Nederlandse bevolking vindt natuur al jaren geen belangrijk beleidsthema van de overheid. Deze dalende lijn in prioriteit van natuur heeft zich in 2017 verder doorgezet. Gezondheidszorg, onderwijs en werkgelegenheid zijn door de jaren heen als de belangrijkste onderwerpen genoemd. Desondanks zien burgers de overheid als de belangrijkste hoofdverantwoordelijke voor natuur, zowel in de stad, als op het platteland als in natuurgebieden. Andere partijen zoals natuurorganisaties, (landbouw)bedrijven en burgers vinden zij wel in belangrijke mate medeverantwoordelijk voor natuur. Het lijkt erop dat deze medeverantwoordelijkheid sinds 2013 iets afneemt.

Er is veel draagvlak voor verschillende beleidsmaatregelen om natuur te beschermen en te verbeteren. Het meeste draagvlak bestaat voor het beschermen van bestaande natuurgebieden, het beschermen van zeldzame planten en dieren en het beheren en onderhouden van natuurgebieden. Maar ook maatregelen als bescherming van natuur op het platteland, meer natuureducatie op scholen en het betrekken van bedrijven en burgers en bij natuur kan op grote steun van de bevolking rekenen. Vergeleken met 2013 is het draagvlak voor de meeste maatregelen toegenomen.

De betrokkenheid van het publiek als gebruiker van natuur, beschermer van natuur en medebeslisser over natuur uit zich vooral in laagdrempelige activiteiten. Wat betreft het gebruik bezoekt ongeveer de helft van de Nederlandse bevolking regelmatig natuurgebieden, stadsgroen en het platteland. Het gebruik van stadsnatuur neemt sinds 2006 toe. Voor informatie over natuur is televisie nog steeds de belangrijkste bron. Internet, tijdschriften en social media raadpleegt men veel minder, al neemt het gebruik van social media sinds 2013 toe. Net als in 2013 heeft twee derde van de Nederlandse bevolking activiteiten voor natuur en landschapsbeheer verricht. Het gaat dan vooral om het ophangen van nestkastjes en afval van anderen opruimen. Het publiek is veel minder actief bij het onderhoud van natuur en landschap, natuureducatie en natuurinventarisaties. Ongeveer een derde van de bevolking is betrokken bij activiteiten die beslissingen over natuur kunnen beïnvloeden. Ook hier gaat het vooral om laagdrempelige activiteiten zoals bij het stemmen het onderwerp natuur mee laten wegen of een handtekening zetten voor de natuur. De betrokkenheid in de vorm van een buurtoverleg bijwonen, actievoeren voor natuur of meedoen aan een burgerinitiatief, is veel geringer. 
Op grond van alle activiteiten die de Nederlandse bevolking onderneemt als gebruiker, beschermer en beslisser, is een indeling gemaakt in vier groepen. De grootste groep (53\%) is matig betrokken. Dit zijn vooral mensen die natuur bezoeken en zich informeren over natuur. Ze doen nauwelijks activiteiten voor natuurbescherming of besluitvorming. Een vijfde van de Nederlanders is weinig betrokken bij natuur en $16 \%$ is redelijk betrokken als gebruiker en beschermer. Ongeveer 1 op de 10 Nederlanders is zeer betrokken; men is op veel fronten actief voor de natuur. De vier groepen zijn sinds 2013 ongeveer gelijk gebleven. Er is potentie om de maatschappelijke betrokkenheid van burgers verder te laten groeien, want ruim tachtig procent spreekt het aan om betrokken te zijn bij de natuur. Men zou willen meedenken over plannen voor natuur, informatie ontvangen en zelf aan de slag bij het onderhoud.

\section{Aanpak monitoringsonderzoek}

Het maatschappelijk draagvlak is in kaart gebracht op basis van drie hoofdindicatoren: belang van natuurbehoud, steun voor natuurbeleid en betrokkenheid bij natuur. Het belang van natuurbehoud gaat over de mate van besef bij de bevolking dat natuur bescherming nodig heeft, de mening over het algemeen belang van natuur en het natuurbelang in relatie tot economie. De tweede indicator, de steun voor het natuurbeleid, heeft betrekking op de noodzaak van overheidsingrijpen, de verantwoordelijkheid voor natuurbescherming en concrete beleidsmaatregelen van de overheid. De derde indicator, betrokkenheid bij natuur, omvat het gedrag van mensen ten aanzien van natuur. Burgers kunnen hierin verschillende rollen hebben: gebruiker, beschermer en beslisser.

De vragenlijst is zoveel mogelijk hetzelfde gebleven als in 2013. Nieuwe ontwikkelingen en inzichten hebben echter geleid tot aantal veranderingen in de vorm van nieuwe vragen en antwoordcategorieën.

Voor de gegevensverzameling is gebruik gemaakt van een online-panel van onderzoeksbureau GfK. Uit dit panel is een steekproef getrokken, gestratificeerd naar geslacht, leeftijd, opleidingsniveau, regio en etniciteit. De respons bedroeg 55,2\% (2525 deelnemers). Dit jaar is voor het eerst ook een analyse gemaakt van de gegevens per provincie. De gegevens zijn geanalyseerd met SPSS en de resultaten zijn beschreven in dit rapport. 


\section{Summary}

In 2017, for the fifth time, a survey was held to measure public support for nature, nature policy and public involvement with nature. This has been monitored about once every five years since 1996 by means of a questionnaire survey of a representative sample of Dutch citizens. The aim of the survey is to inform the government about what the public thinks about nature and nature policy, how involved people are with nature, and whether or not this has changed over the years. A monitoring study makes it possible to describe these trends in support.

\section{Main results}

Public awareness of the importance of nature conservation is substantial. After a dip in 2013, awareness increased again in 2017 . This means that a larger proportion of the population now thinks that the amount of attention given to nature is not excessive, that we are right to be concerned about the future of nature and that the government does not spend too much on nature conservation.

Opinions are divided about the economic importance of nature. One in three people think that nature should not be allowed to stand in the way of economic progress, but at the same time people tend to support the interests of nature conservation over economic interests in the area where they live. People prefer a greener environment to more shops or houses and road pricing to more roads. People also think that generating income is the least important function of nature.

For many years the Dutch population have thought that nature should not be a priority for government policy. This declining trend in the priority afforded to nature continued in 2017. Healthcare, education and employment have been the public's top priorities for many years. Despite this, people think the government bears the greatest responsibility for nature, not only in nature reserves but in urban areas and the countryside as well. They think other parties, such as nature conservation organisations, agricultural firms and industry, also have an important responsibility for nature, but the degree to which they are considered to be responsible has declined somewhat since 2013.

There is considerable support for a range of policy measures to conserve and enhance nature. The greatest support is for protecting existing natural areas, protecting rare plants and animals, and managing and maintaining wildlife habitats. But measures such as protecting nature in the countryside, more nature education in schools, and involving businesses and people in nature can also count on considerable support from the public. Compared with 2013, support for most measures has risen.

The public express their involvement with nature as users, protectors and co-decision-makers mainly in the form of low-threshold activities. Concerning the use of nature, about half the Dutch population regularly visits nature reserves, the countryside or urban green spaces. Use of or engagement with urban nature has been on the increase since 2006. Television is still the main source of information about nature; people consult the internet, magazines and social media much less, although the use of social media has increased since 2013. As in 2013, two-thirds of the Dutch population carried out some form of nature and landscape management activity, mostly fitting nesting boxes and clearing up other people's litter. The public is much less active in habitat maintenance and landscape restoration work, nature education and nature surveys. About a third of the population is involved in activities that can influence decisions on nature. These are also mostly low-threshold activities, such as making nature a consideration when deciding on who to vote for or signing petitions on nature conservation issues. They are much less likely to participate in neighbourhood meetings, campaign for nature or take part in citizens' initiative.

The Dutch population is divided into four groups based on the activities undertaken as users, protectors or decision-makers. The biggest group (53\%) are moderately involved. These are mainly people who visit nature and find out more about nature; they hardly take part in nature conservation work or decision-making activities. A fifth of the Dutch population has little interest in nature, $16 \%$ are 
reasonably involved as users and protectors, and about 1 in 10 are highly involved with nature and active on many fronts. These four groups have remained more or less stable since 2013 . There is potential to raise the level of public involvement with nature, because being involved with nature appeals to more than $80 \%$ of the population. These people are willing to contribute ideas for nature conservation plans, receive information and actively participate in habitat maintenance and landscape upkeep.

\section{Monitoring methods}

The level of public support is determined from three main indicators: the importance of nature conservation, support for nature policy, and involvement with nature. The importance of nature conservation reflects the level of awareness among the population that nature needs protecting, people's opinions about the general importance of nature, and the interests of nature in relation to the economy. The second indicator, support for nature policy, reflects people's opinions about the need for government intervention, the responsibility for nature conservation, and concrete policy measures by government. The third indicator, involvement with nature, reflects people's behaviour regarding nature. People can take on different roles: user, protector and decision-maker.

The questionnaire was kept the same as in 2013 as far as possible. However, new developments and insights led to a number of changes in the form of new questions and answer categories.

The survey sample population was selected from an online panel maintained by research consultancy GfK. The sample was stratified by gender, age, educational level, region and ethnicity. The response rate was $55.2 \%$ (2525 participants). This year, for the first time, an analysis was made of the data by province. The data were analysed using SPSS and the results are described in this report. 


\title{
$1 \quad$ Inleiding
}

\begin{abstract}
Aanleiding
De overheid vindt het belangrijk om te weten in hoeverre mensen betrokken zijn bij de natuur en wat het draagvlak is voor het natuurbeleid. Het Planbureau voor de Leefomgeving (PBL) laat daarom al sinds 1996 een onderzoek naar het maatschappelijk draagvlak voor natuur en natuurbeleid uitvoeren. De peiling wordt gedaan in de vorm van een enquête onder een representatieve groep Nederlanders. Belangrijke onderwerpen hierin zijn de mening van de bevolking over het belang van natuur en natuurbeleid, waardering van, gebruik van en betrokkenheid bij de natuur. De overheid krijgt met de resultaten zicht op het draagvlak voor natuur bij burgers en de ontwikkelingen daarin.
\end{abstract}

Uit de eerdere studies ${ }^{1}$ komt naar voren dat de Nederlandse burger over het algemeen positief denkt over natuur en een redelijke mate van betrokkenheid met de natuur vertoont. De meeste burgers bezoeken regelmatig natuurgebieden, platteland of parken in de stad. Vrij algemeen worden ook de waarde en kwetsbaarheid van de natuur en het belang van natuur erkend. Het grootste draagvlak is te vinden voor het beschermen van bestaande natuurgebieden en het beschermen van zeldzame dieren en planten. Ook natuureducatie op scholen wordt belangrijk geacht. Desondanks geven burgers het beleidsveld natuur weinig prioriteit. Een deel van de Nederlandse bevolking zet zich ook in voor de natuur. In de vorm van vrijwilligerswerk of burgerinitiatief werkt men mee aan beheer en onderhoud van natuur.

De laatste peiling van maatschappelijk draagvlak was in 2013. Een nieuwe draagvlakmeting is van belang om na te gaan hoe draagvlak zich heeft ontwikkeld in de laatste vijf jaar en daarvoor. Sinds 2013 is er bij de rijksoverheid sprake van een omslag in het denken over natuur. In het nieuwe natuurbeleid hoort natuur midden in de samenleving thuis en niet alleen in beschermde natuurgebieden. De rijksoverheid verwacht ook een grotere inbreng van burgers, bedrijven, gemeenten en maatschappelijke organisaties om natuur te beschermen en duurzaam te gebruiken. Ook wat betreft sturing is er een omslag geweest met onder meer de overdracht van grote delen van het natuurbeleid naar de provincies. Dit kreeg vorm in het Natuurpact waarin Rijk en provincies afspraken hebben gemaakt over hun inzet voor onder meer het vergroten van de maatschappelijke en economische betekenis van natuur.

Een herhaling van het onderzoek naar maatschappelijk draagvlak is van belang om na te gaan hoe het draagvlak zich heeft ontwikkeld in de laatste vijf jaar en daarvoor. Hoe denken de burgers over het samengaan van economie en natuur en is er sprake van een toenemende betrokkenheid bij natuur? De resultaten zijn van nut voor de Balans van de Leefomgeving in 2018, waarin maatschappelijke betrokkenheid bij de natuur een belangrijk thema is. Daarnaast vindt in 2019 de tweede evaluatie van het Natuurpact plaats. Bij deze evaluatie zal het versterken van maatschappelijke betrokkenheid bij natuur ook een belangrijk onderwerp zijn. Vooruitlopend hierop wil het PBL daarom ook graag inzicht in de resultaten per provincie.

\section{Doelstelling}

Het doel van deze draagvlakmeting is om antwoord te krijgen op de volgende vragen:

- Hoe ziet het huidige maatschappelijk draagvlak voor natuur, natuurbeleid en betrokkenheid eruit?

- Welke trends zijn in het draagvlak te onderscheiden?

\section{Aanpak}

Dit vijfde draagvlakonderzoek sluit aan bij de vorige edities. Om een duidelijk beeld te krijgen van ontwikkelingen in de tijd, zijn de vragen die in de vorige publieksenquête zijn gesteld zoveel mogelijk ook in de nieuwe enquête opgenomen. Voorafgaand aan de uitvoering van dit onderzoek hebben onderzoekers en opdrachtgever in een aantal bijeenkomsten gediscussieerd over de definitie en

\footnotetext{
${ }^{1} 1996$ (Buijs en Volker, 1997), 2001 (De Boer en Schulting, 2002), 2006 (De Bakker et al., 2007), 2013 (De Boer et al., 2014).
} 
indicatoren voor maatschappelijk draagvlak voor natuur. Het uitgangspunt was om zoveel mogelijk aan te sluiten bij de vorige editie om een vergelijking met voorgaande jaren mogelijk te maken. Om echter huidige ontwikkelingen mee te kunnen nemen, waren er enige veranderingen in de vragenlijst ten opzichte van het onderzoek uit 2013 noodzakelijk, zie paragraaf 2.2 .

De vragenlijst is voorgelegd aan een representatieve groep Nederlanders met behulp van een internetpanel. De data zijn geanalyseerd met SPSS en de resultaten zijn beschreven in dit rapport. De uitkomsten geven een beeld van het huidige draagvlak voor natuur en natuurbeleid en de mate waarin burgers betrokken (willen) zijn. Waar mogelijk wordt een vergelijking gemaakt met de resultaten van voorgaande peilingen. Naast de landelijke cijfers worden voor een groot aantal vragen ook de provinciale resultaten vermeld. In overleg met de opdrachtgever zijn dit vooral de vragen die betrekking hebben op beleid en betrokkenheid.

\section{Leeswijzer}

Na de inleiding met aanleiding en doelstelling voor dit onderzoek, gaan we in hoofdstuk twee in op de definiëring en operationalisering van het concept maatschappelijk draagvlak. In hoofdstuk drie wordt de onderzoeksmethode beschreven. In hoofdstuk vier tot en met zes worden de resultaten van de publieksenquête gepresenteerd. Hoofdstuk vier beschrijft het belang van natuurbehoud. De steun voor natuurbeleid komt in hoofdstuk vijf aan de orde en in hoofdstuk zes gaat het over de betrokkenheid van mensen bij de natuur. Deze resultaten worden waar mogelijk vergeleken met voorgaande edities van deze enquête. Ook wordt de invloed van sociaal-demografische kenmerken beschreven. Tot slot worden in hoofdstuk zeven de onderzoeksvragen beantwoord in de vorm van kernboodschappen en conclusies. 


\section{Theoretische verkenning van draagvlak}

\subsection{Definities en indicatoren van draagvlak in de vorige studies}

In de voorgaande peilingen naar draagvlak voor natuur ${ }^{2}$ wordt op verschillende wijze naar het begrip draagvlak en indicatoren van draagvlak gekeken. Hieronder beschrijven we kort hoe.

In 1997 werden door Buijs en Volker zes dimensies van draagvlak onderscheiden: grondhoudingen, probleembesef, verantwoordelijkheid, houding tegenover natuur, houding tegenover beleid en gedrag. Kennis van de grondhoudingen jegens de natuur is volgens Buijs en Volker cruciaal, omdat deze de basis vormen waarop de andere elementen van draagvlak zijn gefundeerd. De probleemdefinitie, de toewijzing van verantwoordelijkheden en de steun voor meer concrete beleidsdoelen - al deze elementen zijn bepaald door de grondhoudingen die mensen hebben.

In 2002 werden door De Boer en Schulting de zes dimensies uit 1997 opnieuw gemeten met uitzondering van de dimensie verantwoordelijkheid. Deze vijf dimensies werden ondergebracht in drie indicatoren te weten waarden, houding en gedrag. De Boer en Schulting maken daarbij onderscheid in potentieel draagvlak (de waarden) en concreet draagvlak (houdingen en gedragingen). Het eerste wordt als belangrijke graadmeter gezien voor het draagvlak voor natuur(beleid) op de lange termijn. Het concrete draagvlak is een graadmeter voor het draagvlak op de korte termijn.

In het onderzoek van 2007 is door Bakker et al. het draagvlak in kaart gebracht vanuit drie invalshoeken: beelden en waarderingen van natuur, waarderingen van natuurbeleid en natuurbetrokken activiteiten. Deze benadering borduurt voort op de eerder onderscheiden zes dimensies van draagvlak. Een verschil met de voorgaande studies is dat men de grondhouding voor natuur (visies en waarden) niet langer beschouwt als het bepalende fundament voor opvattingen en gedrag ten aanzien van de natuur. Volgens De Bakker et al. (2007) is er theoretisch gezien een verschuiving gaande van waarden naar praktijken. Praktijken kan vertaald worden als praktisch handelen op grond van waarden die routine zijn geworden. De Bakker et al. zijn van mening dat het draagvlak voor natuur(beleid) mede bepaald wordt door gedragspraktijken variërend van vrijwilligerswerk en participatie in besluitvorming tot het kijken van natuurprogramma's op tv en natuurgebruik in productie- en consumptieketens.

De publieksenquête van 2013 (De Boer et al.) hanteert dezelfde indicatoren als uit het onderzoek van De Bakker (2007). De invulling van de indicatoren is echter enigszins gewijzigd. Zo is de indicator natuurbetrokken activiteiten verbeterd en uitgebreid met vragen over burgerinitiatieven. Op grond hiervan is betrokkenheid bij natuur onderscheiden in drie domeinen: burger als gebruiker van natuur, burger als beschermer van natuur en burgers als (mede)beslisser over natuur. Daarnaast is de mate van betrokkenheid onderscheiden in passief en actief. Op grond hiervan is een segmentatie gemaakt van de mate van natuurbetrokkenheid van burgers.

\subsection{Definitie en indicatoren van draagvlak in deze studie}

Voorafgaand aan de uitvoering van dit onderzoek hebben onderzoekers en opdrachtgever in twee bijeenkomsten gediscussieerd over de definitie en indicatoren voor maatschappelijk draagvlak voor natuur, de behoefte om in te spelen op actuele zaken in het natuurbeleid en het behouden van continuïteit in de meting. Dit heeft geleid tot een aantal veranderingen ten opzichte van het onderzoek uit 2013.

\footnotetext{
21996 (Buijs en Volker, 1997), 2001 (De Boer en Schulting, 2002), 2006 (De Bakker et al., 2007), 2013 (De Boer et al., 2014).
} 


\section{Definitie}

Er was behoefte aan een beknopte definitie van het begrip draagvlak. Daarom verstaan we in dit onderzoek onder maatschappelijk draagvlak voor natuur en natuurbeleid het volgende: de steun van de Nederlandse bevolking voor en betrokkenheid bij de natuur en het natuurbeleid.

\section{Indicatoren voor draagvlak}

Het maatschappelijk draagvlak voor natuur wordt in dit onderzoek geduid door drie hoofdindicatoren: (1) Het belang dat mensen hechten aan natuurbehoud, (2) de steun die mensen geven aan het natuurbeleid en (3) de betrokkenheid van mensen bij de natuur. Ten opzichte van 2013 zijn een paar wijzigingen aangebracht in de titels van de hoofdindicatoren en zijn de onderliggende sub-indicatoren ook enigszins gewijzigd. Zie bijlage 1 voor het overzicht van de veranderingen in de vragenlijst.

De drie hoofdindicatoren hangen nauw samen. Ze kunnen worden geanalyseerd op hun onderlinge verbanden, maar ook op hun (verklarende) relatie met sociaal-demografische kenmerken zoals leeftijd, geslacht, opleiding, woonregio. Een positief oordeel over het natuurbeleid kan bijvoorbeeld gerelateerd zijn aan leeftijd of opleiding.

Het draagvlak voor natuur gaat van algemeen naar specifiek. Algemeen draagvlak heeft betrekking op de algemene problematiek van 'de natuur'. Specifiek draagvlak heeft te maken met een bepaald aspect bijvoorbeeld een specifieke beleidsmaatregel of een specifieke actie, zie figuur 2.1.

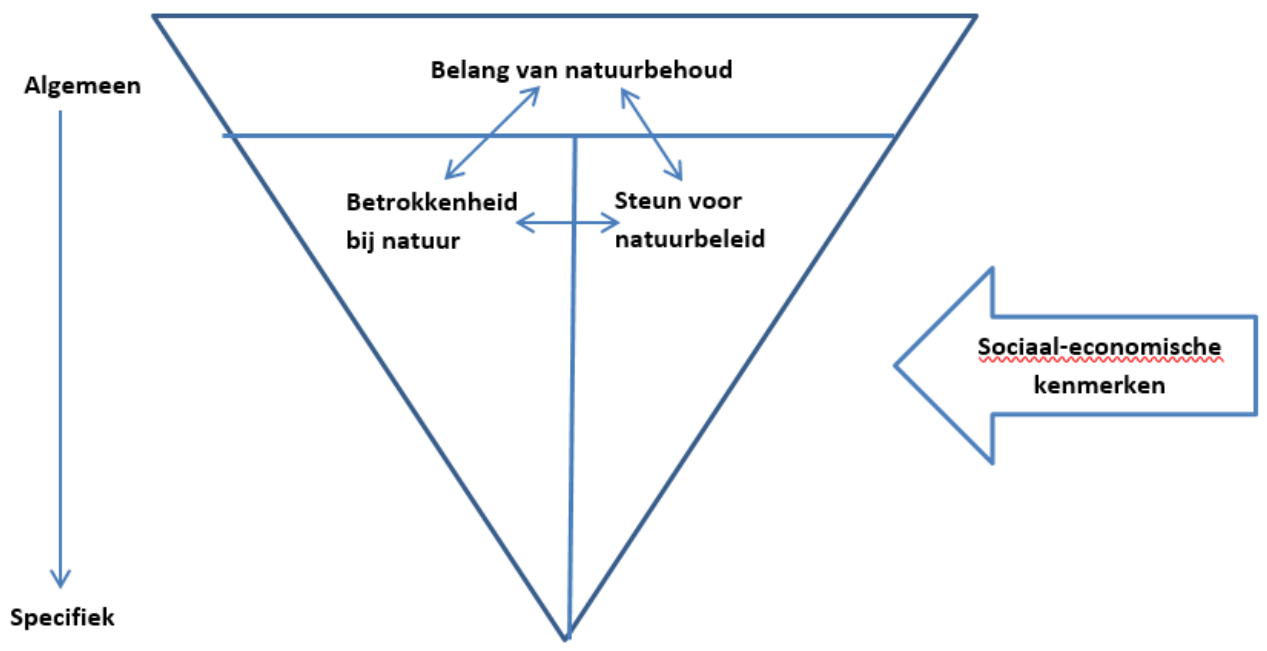

Figuur 2.1 Conceptueel model

In het vervolg van dit hoofdstuk gaan we nader in op de belangrijkste kenmerken van deze indicatoren en de operationalisering daarvan in de meting. Daarbij komt ook aan de orde hoe de operationalisering is geactualiseerd ten opzichte van de vorige meting.

\section{Belang van natuurbehoud}

Het natuurbeleid is onder meer gericht op het beschermen van natuur, maar hoe groot is het besef bij de bevolking dat natuur bescherming nodig heeft? Onder de indicator het belang van natuurbehoud verstaan we hoe belangrijk Nederlanders (het behoud van) natuur vinden. Ziet men natuur als iets dat aandacht en bescherming nodig heeft of als een belemmering voor de economie? Daarnaast horen ook de opvattingen van wat natuur is en hoe we met natuur om moeten gaan (normatieve natuurbeelden) tot deze indicator. Deze indicator vervangt de indicator 'natuurbeelden en waardering van natuur' uit 2013. De belangrijkste reden hiervoor was dat het inmiddels voldoende duidelijk is bij beleidsmakers dat de Nederlandse bevolking natuur breed opvat en het vragen naar het cognitieve natuurbeeld van mensen niet langer noodzakelijk is. 
De vijf sub-indicatoren om de indicator 'het belang van natuurbehoud' te duiden zijn:

1. Besef van belang van natuurbehoud (vraag 12)

2. Belang van natuur ten opzichte van andere belangen zoals woningbouw en infrastructuur (vraag 11)

3. Normatieve natuurbeelden (vraag 13)

4. Belang van natuur in het algemeen (vraag 4)

5. Waardering van natuur in Nederland en in de woonomgeving (vraag 2 en 3 )

\section{Steun voor natuurbeleid}

De steun voor het natuurbeleid heeft betrekking op de noodzaak van overheidsingrijpen, de verantwoordelijkheid voor natuurbescherming en concrete beleidsmaatregelen van de overheid. Hoe belangrijk vindt men natuurbeleid in relatie tot andere beleidsvelden, welke actoren vindt men verantwoordelijk voor de natuur en hoe waardeert men beleidsmaatregelen om natuur te beschermen en te verbeteren.

De drie sub-indicatoren om de indicator 'steun voor natuurbeleid' te duiden zijn:

1. Beleidsprioriteiten van de overheid (vraag 1 )

2. Verantwoordelijkheid voor natuur van verschillende partijen (vraag 14)

3. Waardering van beleidsmaatregelen (vraag 9)

\section{Betrokkenheid bij natuur}

Bij de twee voorgaande indicatoren is draagvlak vooral beschouwd vanuit de opvattingen die mensen hebben voor de natuur en het natuurbeleid. Draagvlak omvat echter ook het gedrag voor natuur, zoals vrijwilligerswerk, bezoek aan natuur en financiële steun. Hieruit blijkt de mate van betrokkenheid bij de natuur en/of het natuurbeleid blijkt. We onderscheiden daarin drie rollen: rol van gebruiker, de rol van beschermer en de rol van beslisser. Elke rol is geoperationaliseerd in een aantal kenmerken. De rol van gebruiker heeft betrekking op bezoek aan natuurgebieden en het verkrijgen van informatie over de natuur. De rol van beschermer uit zich in het doen van activiteiten voor natuur- en landschapsbeheer, het lidmaatschap van natuurbeschermingsorganisaties en in een financiële bijdrage voor natuur. De rol van beslisser is van toepassing op mensen die bezig zijn om besluitvorming over natuur te beïnvloeden of initiatiefnemer zijn van burgerinitiatieven op het gebied van natuur- en landschap. In elke rol onderscheiden we een passieve en een actieve vorm van betrokkenheid.

Naast de daadwerkelijke betrokkenheid wordt ook aandacht besteed aan de potentiële betrokkenheid van burgers bij natuur: wat zouden mensen willen doen en wat zijn hun motieven daarvoor.

1. Burger als gebruiker

- bezoek aan natuur (vraag 5)

- informatie over natuur gebruiken (vraag 6)

2. Burger als beschermer

- activiteiten voor natuur- en landschapsbeheer (vraag 16)

- lidmaatschap natuurorganisatie (vraag 7)

- financiële bijdrage aan natuur (vraag 8)

3. Burger als (mede) beslisser

- activiteiten voor beïnvloeding besluitvorming (vraag 17)

- betrokkenheid bij burgerinitiatieven (vraag $18 \mathrm{~b}$ )

\section{Kwantificeren van draagvlak}

Op basis van bovenstaande indicatoren en sub-indicatoren wordt het draagvlak voor natuur en natuurbeleid en betrokkenheid van de Nederlandse bevolking geanalyseerd en beschreven. De hoeveelheid draagvlak is echter niet eenduidig te kwantificeren, omdat uit het voorgaande is gebleken dat draagvlak een meervoudig begrip is. 



\section{Onderzoeksmethode}

\subsection{Vragenlijst}

Op basis van de set indicatoren uit paragraaf 2.2 is een vragenlijst opgesteld (zie bijlage 2). Hierbij is zo goed mogelijk aangesloten bij de vragen en antwoordcategorieën van de vragenlijst uit 2013 om een vergelijking mogelijk te maken. Desondanks is er wel een aantal wijzigingen ten opzichte van de laatste publieksenquête, omdat de indicatoren waarmee het draagvlak gemeten wordt ook enigszins aangepast zijn. In bijlage 1 staan de indicatoren, vragen en veranderingen in de vragenlijst ten opzichte van 2013. Voor een vergelijking van de vragenlijsten van 1996, 2002 en 2006 verwijzen we naar het rapport van De Bakker et al. (2007) en voor een vergelijking van de vragenlijsten 2006 2013 naar De Boer et al (2013).

\subsection{Onderzoekspopulatie, steekproef en response}

De dataverzameling is uitgevoerd door onderzoeksbureau GfK in de periode van 6 tot en met 18 april 2017. GfK beschikt over een online panel bestaande uit circa 112.500 Nederlanders. Uit dit panel is een steekproef getrokken, gestratificeerd naar geslacht, leeftijd, opleidingsniveau, regio en etniciteit. Bij de steekproeftrekking is rekening gehouden met de populatieverhoudingen zoals bekend uit de Gouden Standaard van het Centraal Bureau voor de Statistiek.

Anders dan bij het onderzoek in 2013 is vooraf tot doel gesteld om ook op provincieniveau representatieve uitspraken te kunnen doen. Om dit te kunnen bereiken zijn er in iedere provincie exact evenveel respondenten uitgenodigd (367 per provincie). Gedurende het veldwerk bleek dat de respons van de groep jongere vrouwen enigszins achterbleef. Daarom zijn er nog 165 extra vrouwen tussen de 16 en 34 jaar uitgenodigd. In totaal zijn 4569 mensen uitgenodigd om aan het onderzoek mee te doen. In de uitnodiging om deel te nemen aan het onderzoek was het onderwerp van de vragenlijst vermeld.

De uiteindelijk behaalde respons bedroeg 55,2\% ( $\mathrm{N}=2525)$. Het aantal deelnemers per provincie was 210. In werkelijkheid is de Nederlandse bevolking natuurlijk niet zo recht evenredig verdeeld over het land. Er wonen veel meer mensen in bijvoorbeeld Zuid-Holland dan in Limburg. Om op nationaal niveau toch representatieve uitspraken te kunnen doen, is een weging toegepast. In dit onderzoek is ervoor gekozen om te wegen op drie variabelen: provincie, geslacht en leeftijdsklasse. Hiermee is gezorgd voor een juiste landelijke afspiegeling van het percentage inwoners (in de leeftijdsrange van 16-74) per provincie, leeftijdsklasse per provincie en geslacht per provincie. Door de weging zullen de resultaten van inwoners uit Zuid-Holland zwaarder meewegen in de 'totaalcijfers' dan die uit Limburg. In tabel 3.1 staan de kenmerken van de respons en populatie.

Tabel 3.1 Kenmerken van de respons (\%) en populatie (\%)

\begin{tabular}{|c|c|c|c|}
\hline & $\begin{array}{l}\text { Ongewogen } \\
\text { respons }(\mathrm{N}=\mathbf{2 5 2 5})\end{array}$ & Gewogen respons & $\begin{array}{l}\text { Populatie volgens } \\
\text { CBS Gouden } \\
\text { Standaard }\end{array}$ \\
\hline \multicolumn{4}{|l|}{ Geslacht } \\
\hline Man & $51,2 \%$ & $50,0 \%$ & $50,0 \%$ \\
\hline Vrouw & $48,8 \%$ & $50,0 \%$ & $50,0 \%$ \\
\hline 16-34 jaar & $25,3 \%$ & $31,2 \%$ & $31,2 \%$ \\
\hline 35-54 jaar & $39,1 \%$ & $37,6 \%$ & $37,6 \%$ \\
\hline 55-74 jaar & $35,6 \%$ & $31,2 \%$ & $31,2 \%$ \\
\hline
\end{tabular}




\begin{tabular}{|c|c|c|c|}
\hline \multicolumn{4}{|l|}{ Hoogst gevolgde opleiding } \\
\hline Laag (geen, basis, Ibo, mavo, weet niet) & $20,7 \%$ & $20,9 \%$ & $32,5^{*}$ \\
\hline Midden (mbo, havo/vwo) & $42,3 \%$ & $42,8 \%$ & $39,2 *$ \\
\hline Hoog (hbo, wo) & $37,0 \%$ & $36,2 \%$ & $28,3^{*}$ \\
\hline \multicolumn{4}{|l|}{ Stedelijkheid } \\
\hline Vier grote steden & $6,7 \%$ & $13,2 \%$ & 13,8 \\
\hline Anders & $93,3 \%$ & $86,8 \%$ & 86,2 \\
\hline \multicolumn{4}{|l|}{ Regio } \\
\hline Groningen & $8,3 \%$ & $3,5 \%$ & $3,5 \%$ \\
\hline Friesland & $8,3 \%$ & $3,8 \%$ & $3,8 \%$ \\
\hline Drenthe & $8,3 \%$ & $2,8 \%$ & $2,8 \%$ \\
\hline Overijssel & $8,3 \%$ & $6,6 \%$ & $6,6 \%$ \\
\hline Flevoland & $8,3 \%$ & $2,4 \%$ & $2,4 \%$ \\
\hline Gelderland & $8,3 \%$ & $11,9 \%$ & $11,9 \%$ \\
\hline Utrecht & $8,3 \%$ & $7,4 \%$ & $7,4 \%$ \\
\hline Noord-Holland & $8,3 \%$ & $16,5 \%$ & $16,5 \%$ \\
\hline Zuid-Holland & $8,4 \%$ & $21,3 \%$ & $21,3 \%$ \\
\hline Zeeland & $8,4 \%$ & $2,2 \%$ & $2,2 \%$ \\
\hline Noord-Brabant & $8,3 \%$ & $14,8 \%$ & $14,8 \%$ \\
\hline Limburg & $8,3 \%$ & $6,7 \%$ & $6,7 \%$ \\
\hline \multicolumn{4}{|l|}{ Etniciteit } \\
\hline Autochtoon + Westerse allochtonen & $91,7 \%$ & $87,9 \%$ & $90,2 \%$ \\
\hline Niet-westerse allochtonen & $8,9 \%$ & $12,1 \%$ & $9,8 \%$ \\
\hline
\end{tabular}

*CBS gegevens 2016 (vanaf 15 jaar)

\subsection{Analyse}

De onderzoeksgegevens zijn opgenomen in een databestand. In totaal zitten 2525 respondenten in het bestand. Bij alle analyses is $\mathrm{N}$ dus 2525, tenzij anders vermeld.

\section{Rechte tellingen}

Per vraag zijn eerst rechte tellingen uitgevoerd voor de gehele dataset om in beeld te krijgen hoeveel mensen welk antwoord hebben gegeven. Op basis hiervan kan bijvoorbeeld worden aangegeven hoeveel procent van de Nederlanders het eens is met een stelling, of hoeveel procent van de Nederlanders gebruik maakt van welke mogelijkheden om iets over natuur te weten te komen. Voor de provincies is alleen de analyse met rechte tellingen gedaan. Meer verdiepende analyses voor de provincies vallen buiten het kader van dit onderzoek.

Bij vragen waarop de respondenten in gradaties konden antwoorden, is ervoor gekozen om de respondenten in te delen in twee groepen. De ene groep bestaat uit respondenten die hebben aangegeven bijvoorbeeld de hoeveelheid natuur (ruim) voldoende te vinden, bepaalde maatregelen (zeer) belangrijk te vinden of het met bepaalde stellingen (helemaal) eens zijn. De andere groep bestaat uit respondenten die gekozen hebben voor één van de andere antwoordcategorieën. Een op deze wijze geaggregeerde variabele heet ook wel een dichotome variabele.

\section{Analyse naar invloed van sociaal-demografische kenmerken}

Vervolgens zijn de draagvlakindicatoren vergeleken met meer algemene sociaal-demografische kenmerken. Nagegaan is in hoeverre de percentages (of gemiddelden) tussen vooraf gedefinieerde groepen met andere achtergrondkenmerken verschillen. In deze studie zijn groepen gedefinieerd op basis van vijf achtergrondkenmerken: geslacht, leeftijd, opleiding, etniciteit en stedelijkheid. Voor de analyse is de respons voor ieder achtergrondkenmerk in twee of drie groepen gesplitst. De indeling in groepen staat samengevat in tabel 3.2. 
Tabel 3.2 Indeling steekproef in sociaal-demografische variabelen $(N=2525)$

\begin{tabular}{|c|c|c|c|}
\hline Kenmerk & Groep 1 & Groep 2 & Groep 3 \\
\hline Geslacht & $\begin{array}{c}\operatorname{Man}(1) \\
50 \%\end{array}$ & $\begin{array}{c}\text { Vrouw (2) } \\
50 \%\end{array}$ & \\
\hline Leeftijd & $\begin{array}{c}16 \text { tot } 35 \text { jaar (1) } \\
31 \%\end{array}$ & $\begin{array}{c}35 \text { tot } 55 \text { jaar }(2) \\
38 \%\end{array}$ & $\begin{array}{c}55 \text { tot } 75 \text { jaar }(3) \\
31 \%\end{array}$ \\
\hline Opleiding & $\begin{array}{l}\text { Laag (1) } \\
21 \%\end{array}$ & $\begin{array}{c}\text { Midden }(2) \\
43 \%\end{array}$ & $\begin{array}{l}\operatorname{Hoog}(3) \\
36 \%\end{array}$ \\
\hline Etniciteit & $\begin{array}{c}\text { Autochtoon en Westerse } \\
\text { allochtoon (1) } \\
88 \%\end{array}$ & $\begin{array}{l}\text { Niet-Westerse allochtoon (2) } \\
12 \%\end{array}$ & \\
\hline Stedelijkheid & $\begin{array}{c}\text { Vier grote steden (1) } \\
13 \%\end{array}$ & $\begin{array}{l}\text { Overig Nederland (2) } \\
\qquad 87 \%\end{array}$ & \\
\hline
\end{tabular}

Er zijn twee statistische toetsen gebruikt om na te gaan of de gemiddelden tussen de groepen gelijk zijn. Daarbij zijn analyses gedaan op de bevraagde antwoordcategorieën (en dus niet op de hiervan afgeleide dichotome variabelen). De keuze van toets hangt samen met het aantal groepen dat voor een achtergrondkenmerk is onderscheiden: voor de kenmerken die zijn verdeeld naar twee groepen (geslacht, etniciteit, stedelijkheid) is de T-toets gebruikt, voor leeftijd en opleidingsniveau is de Anova-toets gebruikt. Voor een aantal vragen bestaat de mogelijkheid om de antwoordcategorie 'weet niet' aan te vinken. Voor de statistische toetsing zijn deze antwoorden buiten beschouwing gelaten, aangezien ze anders de berekening van gemiddelden zouden vertroebelen.

In dit rapport worden alleen significante verschillen beschreven. Voor het bepalen of de gemiddelden van groepen onderling afwijken, zijn drie significantieniveaus onderscheiden, die gelijk staan aan een betrouwbaarheid van respectievelijk $95 \%, 99 \%$ of $99,9 \%$. Alle significante verschillen met ook vermelding van de betrouwbaarheid zijn weergegeven in bijlage 3, geordend per enquêtevraag in de volgorde waarin de vragen in het rapport worden besproken. In de hoofdtekst worden de hoofdlijnen in bevindingen besproken; de verschillen zijn te omvattend om in detail op in te gaan. Daarbij is de keuze gemaakt om voor de vragen waarbij mensen meerdere antwoorden konden geven, enkel de verschillen uit te lichten voor de drie meest gegeven antwoorden.

\section{Analyses in de tijd}

Een vergelijking is gemaakt van de opvattingen van het publiek in 2017 met de opvattingen in voorgaande publieksenquêtes. Hiervoor is de data van eerdere jaargangen (1996, 2001, 2006 en 2013) aan de database van 2017 toegevoegd, voor de 2017-vragen die ook in eerdere jaren zijn gesteld. Vervolgens is per variabele geanalyseerd of zich significante verschillen tussen de opvattingen in de verschillende jaren voordoen. De data voor 2017 zijn gewogen, vanwege de gestratificeerde steekproeftrekking naar provincies in dit jaar. Voor eerdere jaren hoefden de data niet gewogen te worden.

Significantietoetsen zijn enkel gedaan voor de jaargangen 2006, 2013 en 2017 en waar relevant op de dichotome variabelen. Welke toets gebruikt is, is afhankelijk van het meetniveau en het aantal te vergelijken jaargangen: getoetst is met behulp van de Chikwadraat toets voor de nominale variabele van vraag 18, voor het ordinale niveau (vraag 14) Mann Whitney (bij vergelijking van twee jaren) en Kruskall Wallis-toets (bij vergelijking van meer dan twee jaren), en voor interval niveau en dichotome variabelen de T-toets (vergelijking van twee jaren) en Anova (vergelijking van meer dan twee jaren). Indien zich bij vergelijking van drie of meer jaren verschillen voordoen, is vervolgens aan de hand van een Post-Hoctoets, te weten Bonferroni, nagegaan tussen welke jaren hier sprake van is. Post Hoc is dus uitgevoerd na de algemene statistische test Anova, om na te gaan tussen exact welke jaren de verschillen zich voordoen. Voor de Kruskall-Wallistoets vormde Mann Whitney de Post-Hoctoets.

Alle significante verschillen met ook vermelding van de betrouwbaarheid zijn weergegeven in bijlage 4 , geordend per enquêtevraag in de volgorde waarin de vragen in het rapport worden besproken. In de hoofdtekst worden de hoofdlijnen in bevindingen besproken. 



\section{$4 \quad$ Belang van natuurbehoud}

\section{$4.1 \quad$ Inleiding}

In dit hoofdstuk gaan we in op de indicator het belang van natuurbehoud: in welke mate zijn burgers doordrongen van het besef om natuur te beschermen, hoe gaat men om met dilemma's tussen natuur en economie en waarom vinden burgers natuur belangrijk. Ook presenteren we bij de voorkeuren van burgers wat betreft de omgang met en de inrichting van natuur. Tot slot wordt ook de waardering van de hoeveelheid natuur in Nederland en in de woonomgeving besproken.

\subsection{Belang van natuurbehoud}

\subsubsection{Landelijk beeld}

Uit tabel 4.1 blijkt dat het besef van het belang van natuur hoog is: $71 \%$ van de Nederlandse bevolking vindt de aandacht voor natuur niet overdreven en $60 \%$ vindt dat we ons terecht zorgen maken over de toekomst van de natuur. Ook vindt $43 \%$ dat de overheid te weinig geld uitgeeft aan natuurbehoud; 37\% denkt hier neutraal over. De burgers hebben geen uitgesproken mening over de stelling dat natuur geen belemmering mag zijn voor economische vooruitgang: $36 \%$ denkt hier neutraal over, $33 \%$ is het er niet mee eens en $29 \%$ is het er wel mee eens.

Tabel 4.1 Mening over het belang van natuurbehoud in Nederland (\%)

\begin{tabular}{|c|c|c|c|c|}
\hline Stellingen & $\begin{array}{l}\text { (helemaal) } \\
\text { eens }\end{array}$ & $\begin{array}{l}\text { niet eens, } \\
\text { niet oneens }\end{array}$ & $\begin{array}{c}\text { (helemaal) } \\
\text { niet mee } \\
\text { eens }\end{array}$ & $\begin{array}{l}\text { weet ik } \\
\text { niet }\end{array}$ \\
\hline Al die aandacht voor natuur is overdreven & 8 & 20 & 71 & 1 \\
\hline \multicolumn{5}{|l|}{ We maken ons te veel zorgen over de toekomst van de } \\
\hline natuur in Nederland & 18 & 21 & 60 & 1 \\
\hline De overheid geeft te weinig geld uit aan natuurbehoud & 43 & 37 & 12 & 8 \\
\hline $\begin{array}{l}\text { De natuur mag geen belemmering zijn voor economisch } \\
\text { vooruitgang }\end{array}$ & 29 & 36 & 33 & 3 \\
\hline
\end{tabular}

Vrouwen zijn het minder vaak eens met de uitspraken 'Al die aandacht ...' en 'We maken ons...' dan mannen. Ook leeftijd doet er voor deze uitspraken toe: ouderen (55-75 jaar) zijn het minder eens met de uitspraak 'Al die aandacht...' dan jongere leeftijdsgroepen en voor de uitspraak 'We maken ons...' is het andersom: jongeren (15 tot 35 jaar) zijn het hier minder mee eens. Opleidingsniveau doet er toe voor drie uitspraken: 'Al die aandacht...', 'We maken ons...' en 'De natuur mag...'. Hoogopgeleiden zijn het minder eens met deze drie uitspraken. Bewoners van de vier grote steden zijn het tot slot meer eens met de uitspraak 'De overheid geeft...', terwijl zij het minder positief zijn over de uitspraak 'De natuur mag...'. Het patroon voor de genoemde uitspraken is hiermee dat vrouwen, hoogopgeleiden en stedelingen meer belang hechten aan natuurbehoud.

\subsubsection{Provincies}

In de provincies varieert het percentage burgers dat de aandacht voor natuur overdreven vindt van $61 \%$ in Zeeland tot $76 \%$ in Friesland.

Inwoners van Friesland (76\%), Utrecht (75\%) en Noord-Brabant (74\%) zijn het vaker niet eens met de stelling dat we ons teveel zorgen over de toekomst van de natuur dan de inwoners uit de andere provincies. 
Op de stelling 'De overheid geeft te weinig geld uit aan natuurbehoud' lopen de scores op (helemaal) mee eens van $41 \%$ (Gelderland) tot 55\% (Friesland).

In Zeeland is de meeste aanhang te vinden voor de stelling 'De natuur mag geen belemmering zijn voor economische vooruitgang' (40\%) en in Friesland het minst (25\%), zie de figuren 4.1 t/m 4.4.

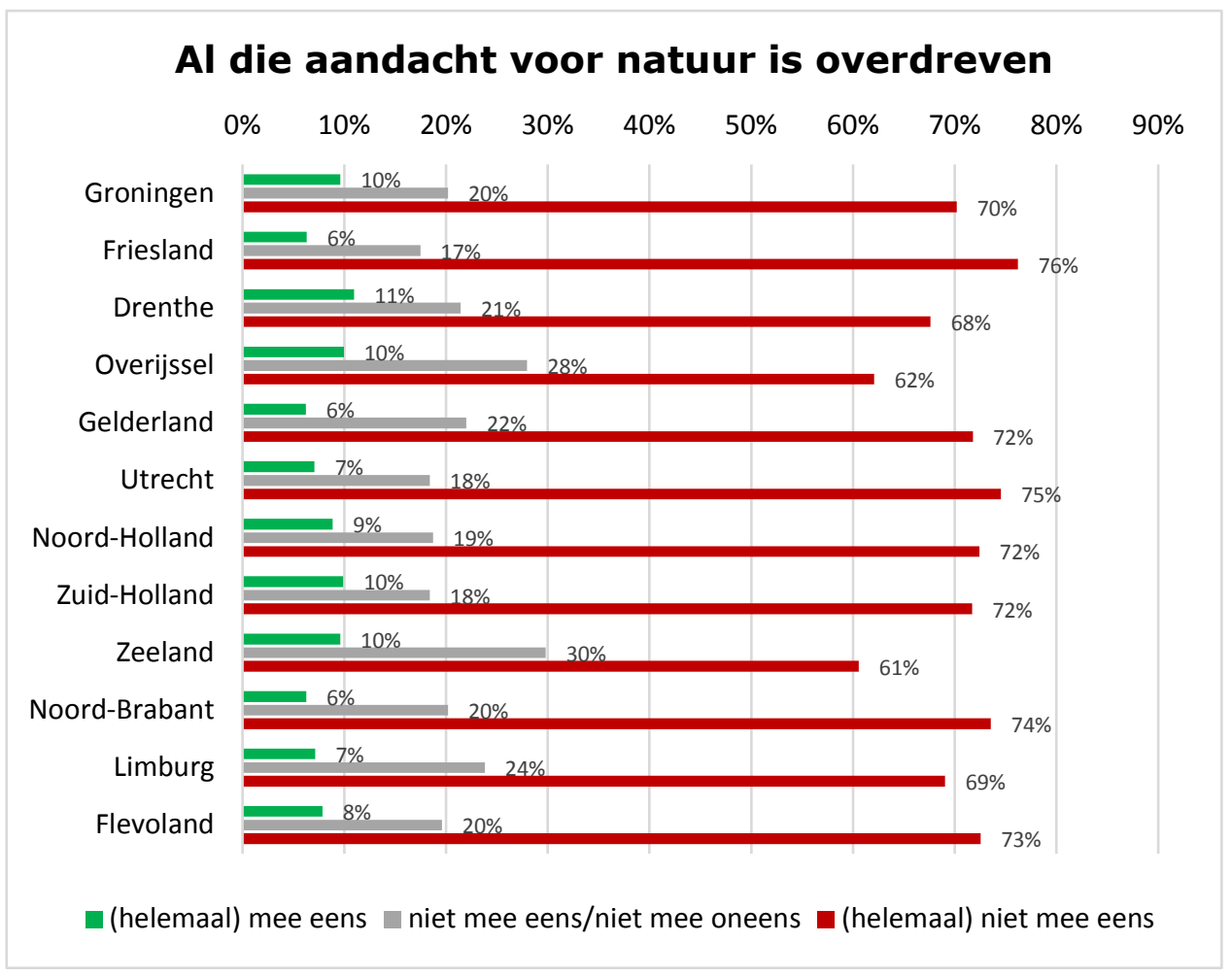

Figuur 4.1 Mening over de uitspraak 'Al die aandacht voor natuur is overdreven.'

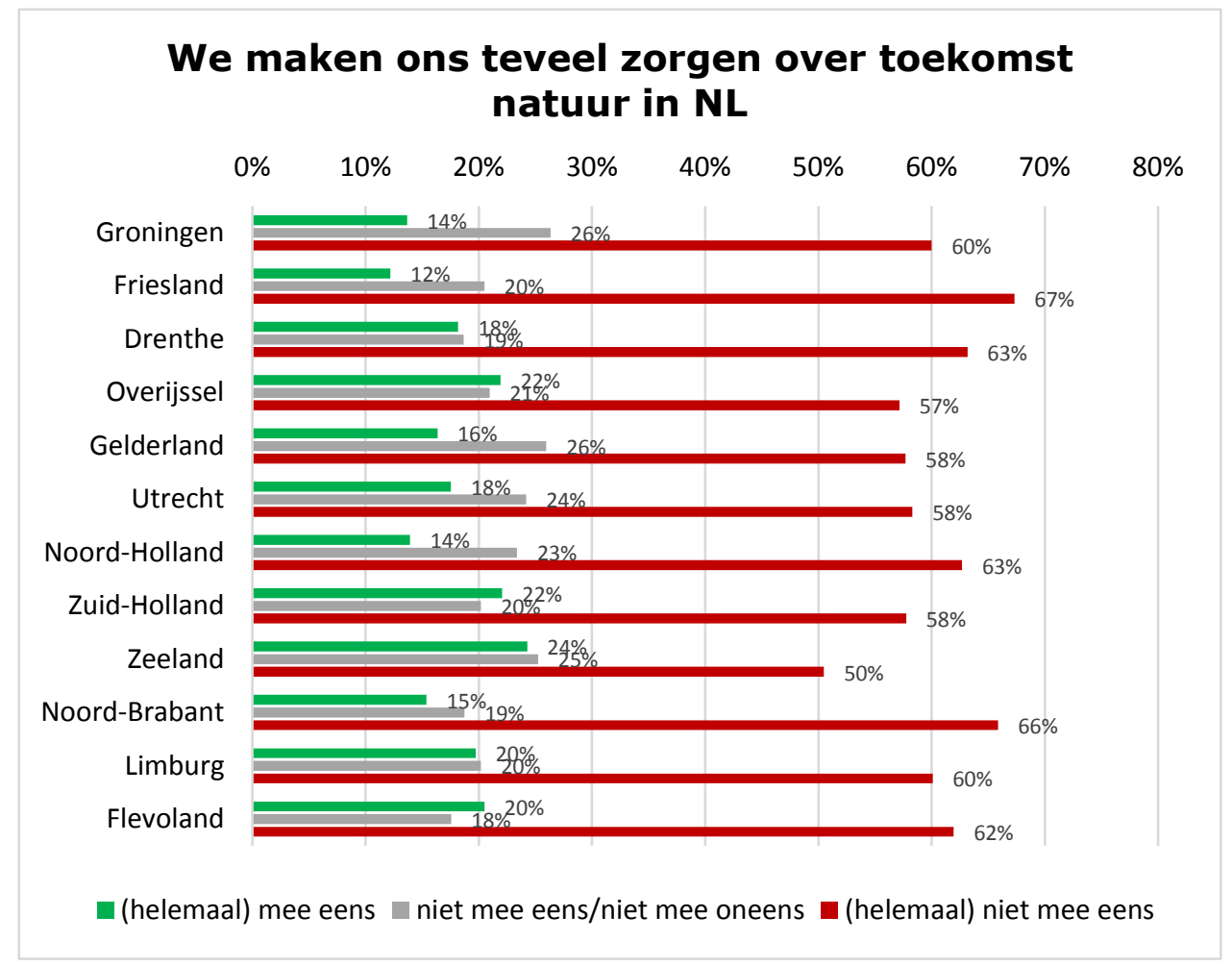

Figuur 4.2 Mening over de uitspraak 'We maken ons teveel zorgen over de toekomst van de natuur in Nederland.' 


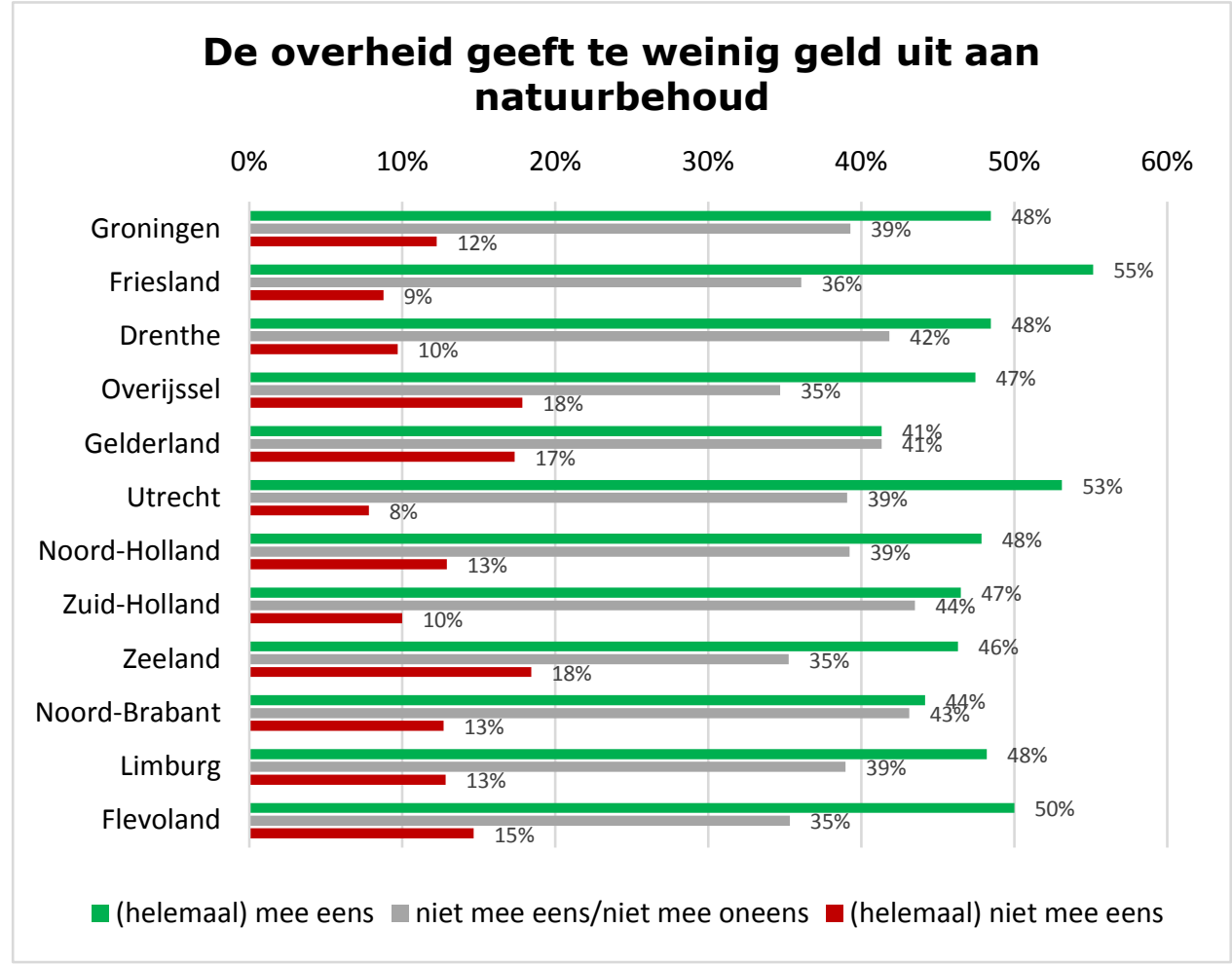

Figuur 4.3 Mening over de uitspraak 'De overheid geeft te weinig geld uit aan natuurbehoud.'

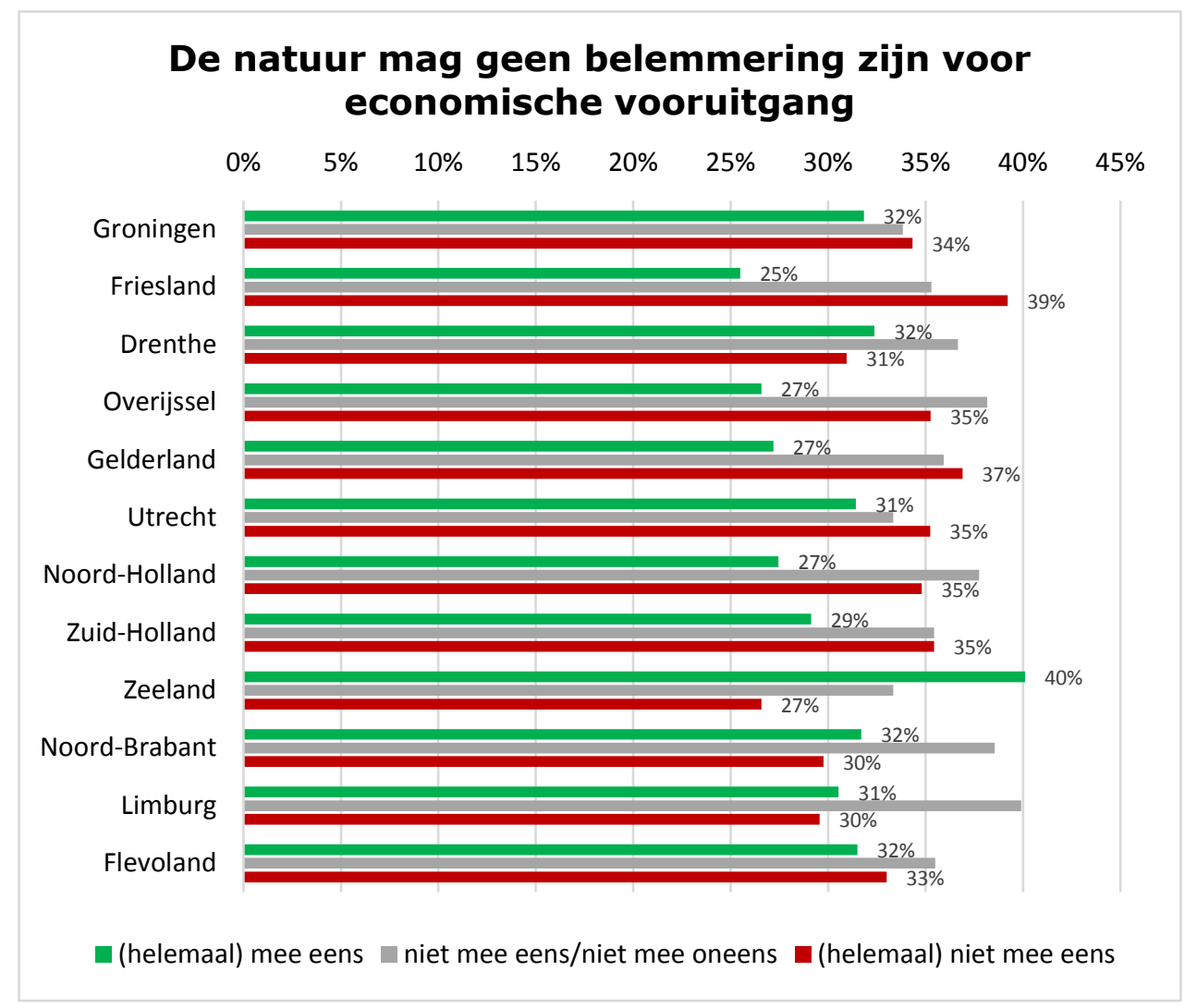

Figuur 4.4 Mening over de uitspraak 'De natuur mag geen belemmering zijn voor economische vooruitgang.' 


\subsubsection{Vergelijking met eerdere jaren}

In drie eerdere jaargangen van de draagvlakenquête zijn de vier stellingen over het belang van natuurbehoud ook voorgelegd. De vraagformulering is bijna identiek gebleven in de loop van de jaren. In 2006 en 2013 werd in de derde stelling de term rijksoverheid gebruikt in plaats van overheid. In 2001 waren de vijf antwoordcategorieën licht afwijkend: 'helemaal mee eens', 'grotendeels mee eens', 'neutraal', 'grotendeels mee oneens' en 'helemaal mee oneens'.

De vier stellingen maken inzichtelijk in welke mate burgers zijn doordrongen van het besef om natuur te beschermen. Drie van de vier stellingen zijn in de vragenlijst negatief geformuleerd in relatie tot probleembesef; voor een betere interpreteerbaarheid zijn deze in figuur 4.5 omgezet naar een positieve formulering voor natuur: Al die aandacht voor natuur is niet overdreven, We maken ons niet te veel zorgen..., De natuur mag een belemmering.... In figuur 4.5 is vervolgens het probleembesef weergegeven via het percentage Nederlanders dat het (helemaal) eens is met de stellingen; een hoger percentage duidt daarmee op een hoger maatschappelijk probleembesef omtrent het belang van natuur.

Figuur 4.5 laat zien dat het maatschappelijk besef van het belang van natuurbehoud door de jaren heen substantieel is. Daarbij valt op dat de dalende lijn in probleembesef die na 2001 is ingezet, in 2017 grotendeels is gestopt en weer ombuigt naar het hoge niveau van 2001: een groter aandeel van de Nederlanders vindt het belangrijk dat er veel aandacht is voor natuur (van $66 \%$ in 2013 naar $71 \%$ in 2017) en dat de overheid geld uitgeeft aan natuurbehoud, van 39\% in 2013 naar $47 \%$ in 2017. Opvallend is verder de stijging van het percentage Nederlanders dat niet vindt dat we ons te veel zorgen maken over de toekomst van natuur in Nederland. In 2001 ging het om 56\%, in 2006 daalde dit naar $48 \%$ en dat bleef vrij stabiel in 2013 (48\%) om in 2017 te groeien naar 60\% van de Nederlanders.

Het aandeel Nederlanders dat in 2017 vindt dat de natuur een belemmering mag zijn voor economische vooruitgang is met 33\% vergelijkbaar met 2006 en 2013. Dit is daarmee de enige stelling waarvoor zich geen verschuivingen in de tijd hebben voorgedaan. Veranderingen in opvattingen voor de drie andere stellingen doen zich met name voor tussen 2013 en 2017: het publiek hecht er in 2017 meer aan dat de overheid geld uitgeeft aan natuurbehoud en spreekt zich explicieter uit voor aandacht voor natuur. Ook scharen in 2017 meer mensen zich achter de uitspraak dat we ons niet te veel zorgen maken over de toekomst van natuur in Nederland (zie ook bijlage 4).

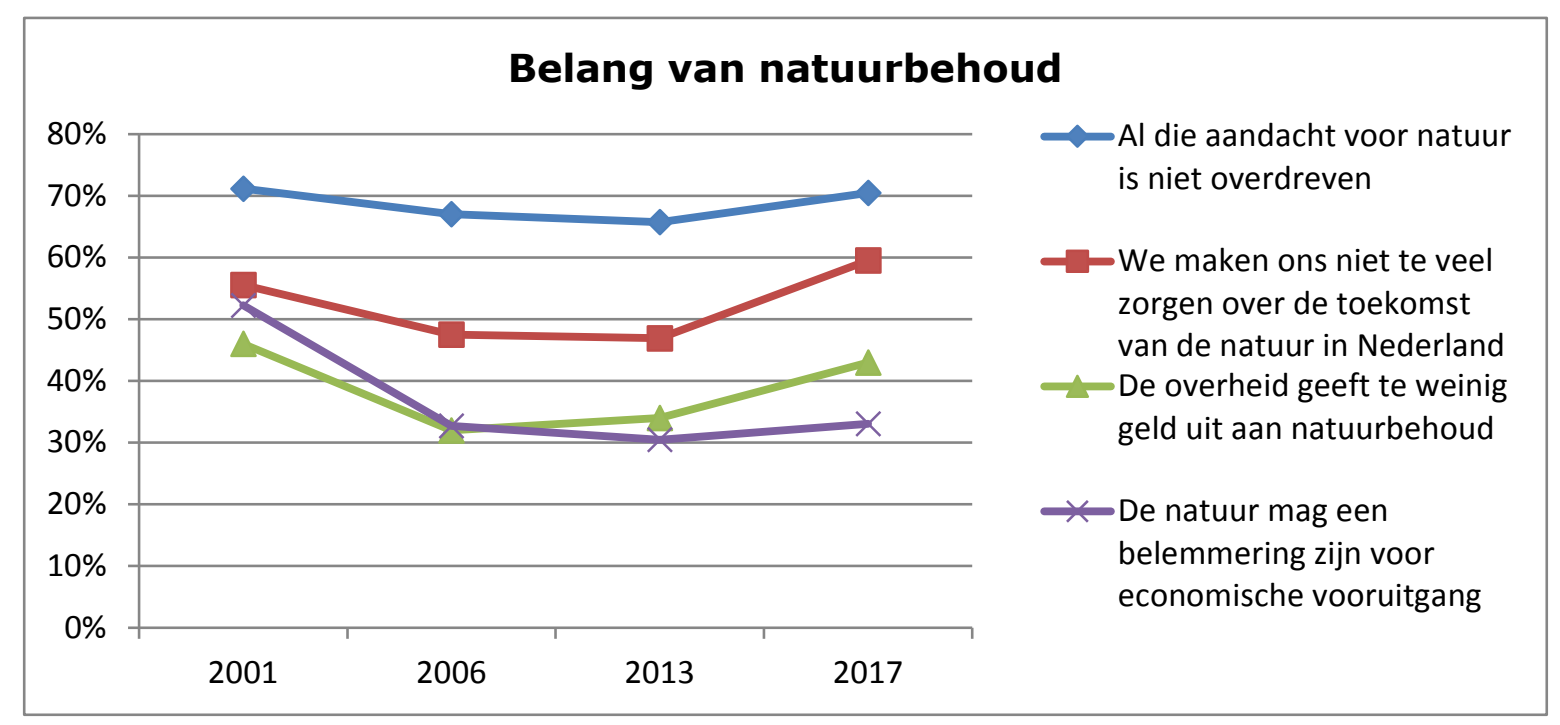

Figuur 4.5 Percentage Nederlanders dat het (helemaal) eens is met de stellingen over het belang van natuurbehoud in 2001, 2006, 2013 en 2017. 


\subsection{Dilemma's natuur en economie}

\subsubsection{Landelijk beeld}

Beslissingen over kwaliteit en kwantiteit van natuur zijn vaak onderdeel van complexe afwegingen veelal tussen sociaaleconomische- en natuurbelangen. De Nederlandse bevolking is gevraagd hoe zij tegenover dit soort belangenafwegingen staan door middel van het voorleggen van een aantal dilemma's. Daarbij konden zij een keuze maken in de richting van natuur of economie door het geven van een score 1 tot en met 4 .

De dilemma's tussen economie en groen worden allemaal in het voordeel van de natuur beslist. Een meerderheid kiest voor meer groen in plaats van meer winkels $(82 \%)$, meer nieuwe natuur in plaats van meer woningen $(70 \%)$, meer speelveldjes/bomen in plaats van meer parkeerplaatsen, files bestrijden door rekening rijden in plaats van extra wegen (54\%) en kleinschalige landbouw met duurdere producten in plaats van grootschalige landbouw met goedkopere producten (57\%). Wat opvalt is dat de keuze voor natuur minder dominant is op het moment dat deze keuze direct gekoppeld is aan de eigen portemonnee, zie tabel 4.2 .

Tabel 4.2 Keuze voor economie of natuur (\%).

\begin{tabular}{|c|c|c|c|c|c|c|}
\hline Keuze voor economie & 1 & 2 & 3 & 4 & Keuze voor natuur & g.s. 2017 \\
\hline Meer winkels in mijn gemeente & 3 & 15 & 44 & 38 & Meer groen in mijn gemeente & 3.2 \\
\hline Meer woningen in mijn gemeente & 6 & 24 & 48 & 22 & Aanleg nieuwe natuur in mijn gemeente & 2.9 \\
\hline Meer parkeerplaatsen in mijn & & & & & Meer speelveldjes en bomen in mijn & 3.0 \\
\hline woonwijk & 6 & 17 & 45 & 31 & woonwijk & \\
\hline Files bestrijden door extra wegen & 17 & 29 & 31 & 23 & Files bestrijden door rekening rijden & 2.6 \\
\hline Grootschalige landbouw met & & & & & Kleinschalige landbouw met duurdere & 2.7 \\
\hline goedkopere producten & 10 & 33 & 39 & 18 & producten & \\
\hline \multicolumn{7}{|c|}{$1=$ helemaal economie, $2=$ meer economie, $3=$ meer natuur, $4=$ helemaal natuur } \\
\hline s. $=$ gemiddelde score op schaal $1-4$ & & & & & & \\
\hline
\end{tabular}

Leeftijd doet er voor drie dilemma's toe: ouderen verkiezen vaker dan jongeren groen boven winkels en kleinschalige landbouw boven grootschalige landbouw, 35-55 jarigen kiezen meer dan de andere twee leeftijdsgroepen voor nieuwe natuur in plaats van woningen. Ook het opleidingsniveau is van invloed. Hoger opgeleiden kiezen meer voor speelveldjes (in plaats van parkeerplekken), rekeningrijden (in plaats van extra wegen) en kleinschalige landbouw. Autochtonen kiezen ook meer dan allochtonen voor speelveldjes en kleinschalige landbouw, ook kiezen zij vaker voor aanleg van nieuwe natuur en niet meer woningen. Stedelingen kiezen vaker voor groen (in plaats van winkels) en kleinschalige natuur. Ouderen, hoger opgeleiden en stedelingen gaan dus in relatie tot het dilemma groen versus economie meer voor groen dan jongeren, lager opgeleiden en niet-stedelingen.

\subsubsection{Vergelijking met eerdere jaren}

In 2006 en 2013 is exact dezelfde vraag gesteld als in 2017. In 2001 en 1996 zijn geen vergelijkbare vragen gesteld.

In figuur 4.6 is de gemiddelde score van de vijf dilemma's op de antwoordschaal 1-4 weergegeven. De figuur maakt duidelijk dat in vrijwel alle jaren de dilemma's tussen economie en natuur in het voordeel van natuur uitpakken, met uitzondering van 2013 voor het dilemma over de manier waarop files bestreden moeten worden. Toen scoorde dit gemiddeld 2,4; net onder het neutrale niveau van 2,5. Significantie-analyses tonen aan dat de opvattingen over alle dilemma's natuur - economie in de loop der jaren zijn veranderd en dat de opvattingen in 2017 weer richting die van 2006 gaan (zie ook bijlage 4). Dat geldt voor de dilemma's groen-winkels (in 2017 meer ten faveure van groen t.o.v. 2013, in 2017 weer op het niveau van 2006), rekeningrijden-wegen (hetzelfde patroon: in 2017 meer ten faveure van rekeningrijden t.o.v. 2013, in 2017 weer op het niveau van 2006). Het dilemma woningen-natuur verschuift daarentegen ten opzichte van 2013 in 2017 meer richting woningen, maar -zoals eerder aangegeven- is in absolute zin de opvatting nog steeds pro-groen. 


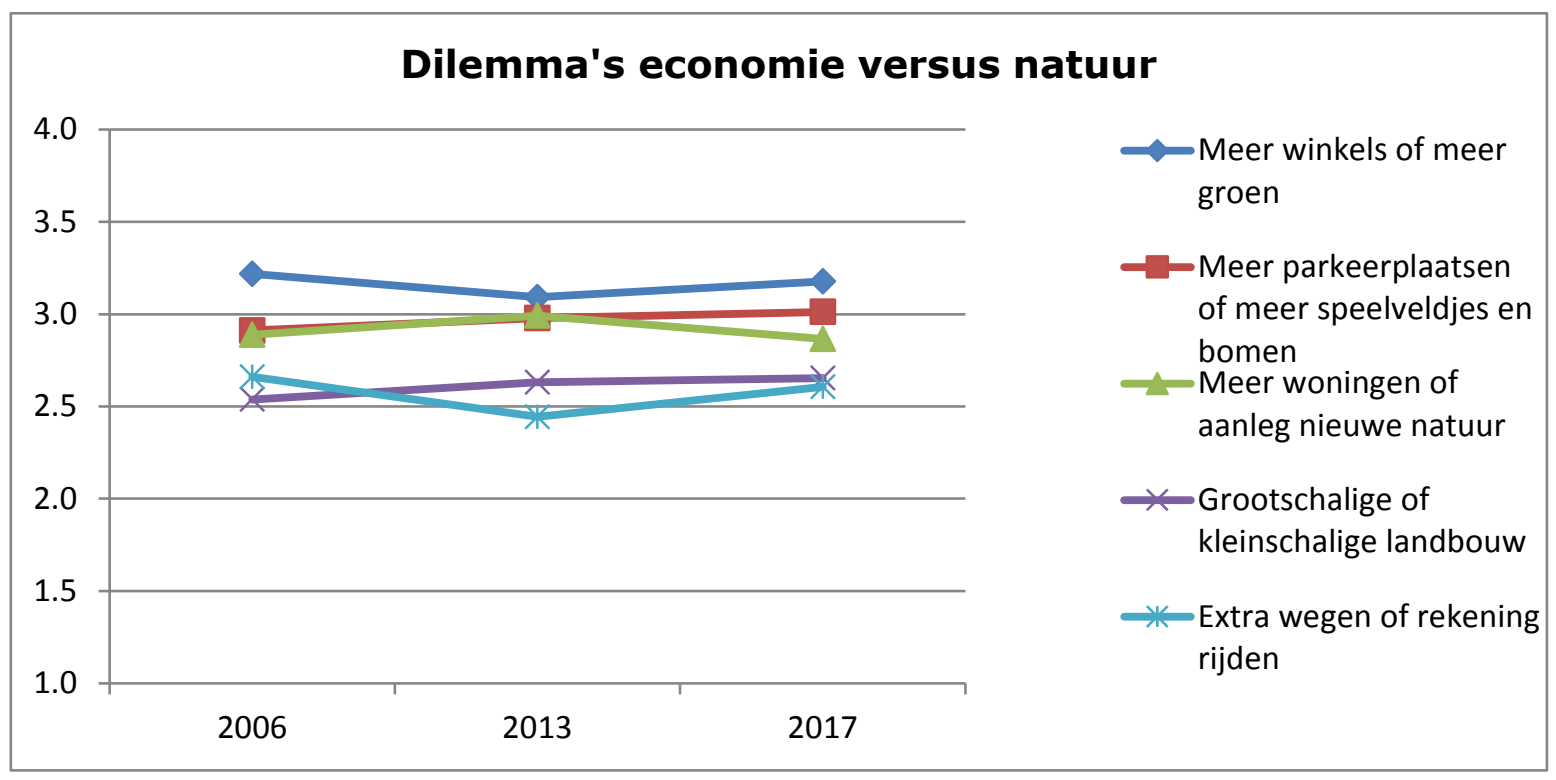

Figuur 4.6 Gemiddelde score op schaal 1-4 (1=pro economie, 4=pro natuur) van Nederlanders op vijf dilemma's over het belang van economie versus natuur in 2006, 2013 en 2017.

\subsection{Waarom vinden mensen natuur belangrijk?}

\subsubsection{Landelijk beeld}

Natuur kan verschillende functies hebben zoals recreatieve, economische of ethische functies. Aan de Nederlandse bevolking is gevraagd waarom ze natuur belangrijk vinden. Allereerst hebben burgers van alle redenen apart aangegeven hoe belangrijk men die vindt en vervolgens is gevraagd wat men de drie belangrijkste functies van natuur vindt.

In tabel 4.3 staat hoe belangrijk de Nederlandse bevolking de verschillende functies van natuur vindt. Uit deze cijfers blijkt dat men de meeste functies zeer belangrijk vindt. Alleen over de functie geld verdienen met natuur zijn de meningen verdeeld: $37 \%$ vindt dit (zeer) belangrijk en $28 \%$ juist niet.

Tabel 4.3 Mening over het belang van natur in Nederland (\%)

\begin{tabular}{|c|c|c|c|c|}
\hline Stellingen & $\begin{array}{c}\text { (zeer) } \\
\text { belangrijk }\end{array}$ & $\begin{array}{l}\text { niet belang- } \\
\text { rijk, niet } \\
\text { onbelangrijk }\end{array}$ & $\begin{array}{c}\text { (helemaal) } \\
\text { niet } \\
\text { belangrijk }\end{array}$ & $\begin{array}{c}\text { weet ik } \\
\text { niet }\end{array}$ \\
\hline Voor de gezondheid (bijv. schone lucht) & 97 & 2 & 0 & 1 \\
\hline Aan onze kinderen verplicht om natuur te beschermen & 94 & 4 & 1 & 1 \\
\hline Voor de landbouw (bijv. bestuiven van gewassen) & 93 & 5 & 1 & 1 \\
\hline Voor recreatie (bijv. om in te wandelen en te fietsen) & 92 & 6 & 1 & 1 \\
\hline Voor de wetenschap (bijv. als bron voor medicijnen) & 82 & 14 & 2 & 2 \\
\hline
\end{tabular}

De verschillen in opvattingen tussen groepen met andere sociaal-demografische kenmerken worden voor de vijf meest genoemde redenen van natuurbehoud besproken. Vrouwen hechten meer dan mannen aan natuur voor de gezondheid, voor de generatie na ons, en aan natuur om van te genieten. Ouderen (55-75) kiezen vaker dan andere leeftijden voor natuur om van te genieten, natuur voor gezondheid en voor de generatie na ons. Ouderen (35-plus) vinden natuur voor de landbouw meer belangrijk dan jongeren (15-35 jaar). Lager opgeleiden vinden natuur om van te genieten belangrijker dan hoogopgeleiden, hoogopgeleiden hechten meer belang aan natuur voor de gezondheid. 
Autochtonen hechten meer dan allochtonen aan natuur voor de volgende generatie. Stedelingen vinden natuur om van te genieten belangrijker dan niet-stedelingen, net als natuur voor de landbouw.

Bij het aangeven van de drie belangrijkste functies van natuur, scoort gezondheid veruit het hoogst; $78 \%$ vindt dit de belangrijkste reden, gevolgd door de reden dat we verplicht zijn om natuur te beschermen voor onze kinderen (47\%). Als de minst belangrijke reden wordt de functie geld verdienen genoemd, zie figuur 4.7 .

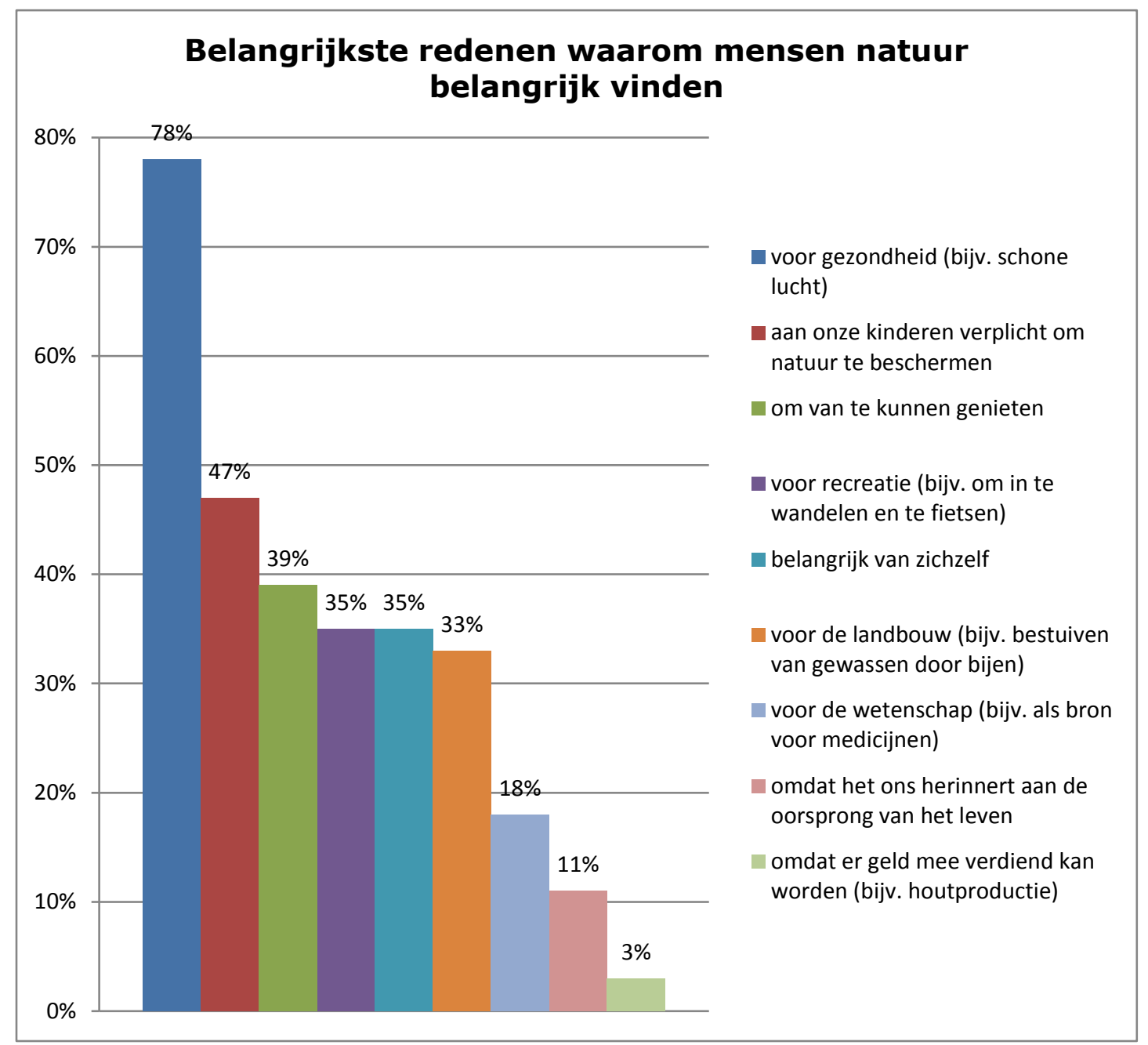

Figuur 4.7 Belangrijkste redenen waarom mensen natuur belangrijk vinden (\%).

\subsubsection{Provincies}

Er is weinig verschil tussen de provincies wat betreft de meest belangrijkste reden waarom mensen natuur belangrijk vinden; de score op gezondheid varieert van $78 \%$ tot $81 \%$, zie figuur 4.8 . 


\section{Belangrijkste redenen waarom natuur belangrijk wordt gevonden}

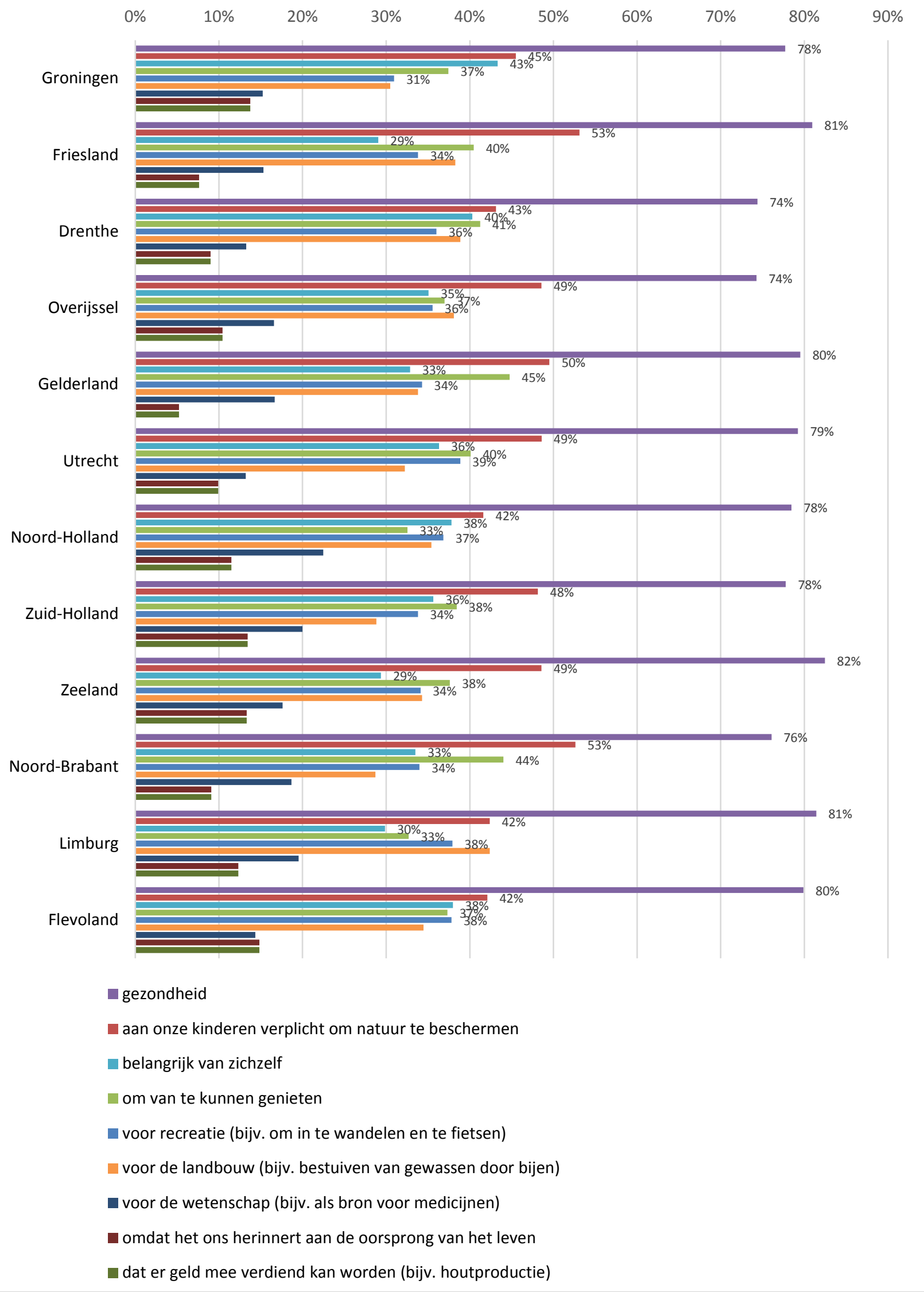

Figuur 4.8 Belangrijkste reden waarom natuur belangrijk wordt gevonden per provincie. 


\subsection{Gewenste omgang met de natuur}

\subsubsection{Landelijk beeld}

De Nederlandse bevolking kreeg elf stellingen gepresenteerd over de wenselijkheid van menselijk ingrijpen in de natuur (figuur 4.9). Een meerderheid van de burgers (78\%) ziet liever geen bebouwing in de natuur. Er is verdeeldheid over de noodzaak van menselijk ingrijpen in de natuur om de natuur te beschermen. Enerzijds vindt men dat hulp is toegestaan in de vorm van het afsluiten van gebieden voor bezoekers (64\%), bomen en struiken kappen ten behoeve van het vergroten van soorten (55\%), jacht op herten, wilde zwijnen of ganzen als deze dieren overlast veroorzaken (51\%) en het bijvoeren van dieren in koude winters (40\%). Maar ook is een meerderheid van mening dat naarmate een natuurgebied langer door mensen met rust is gelaten, de waarde toeneemt $(62 \%)$.

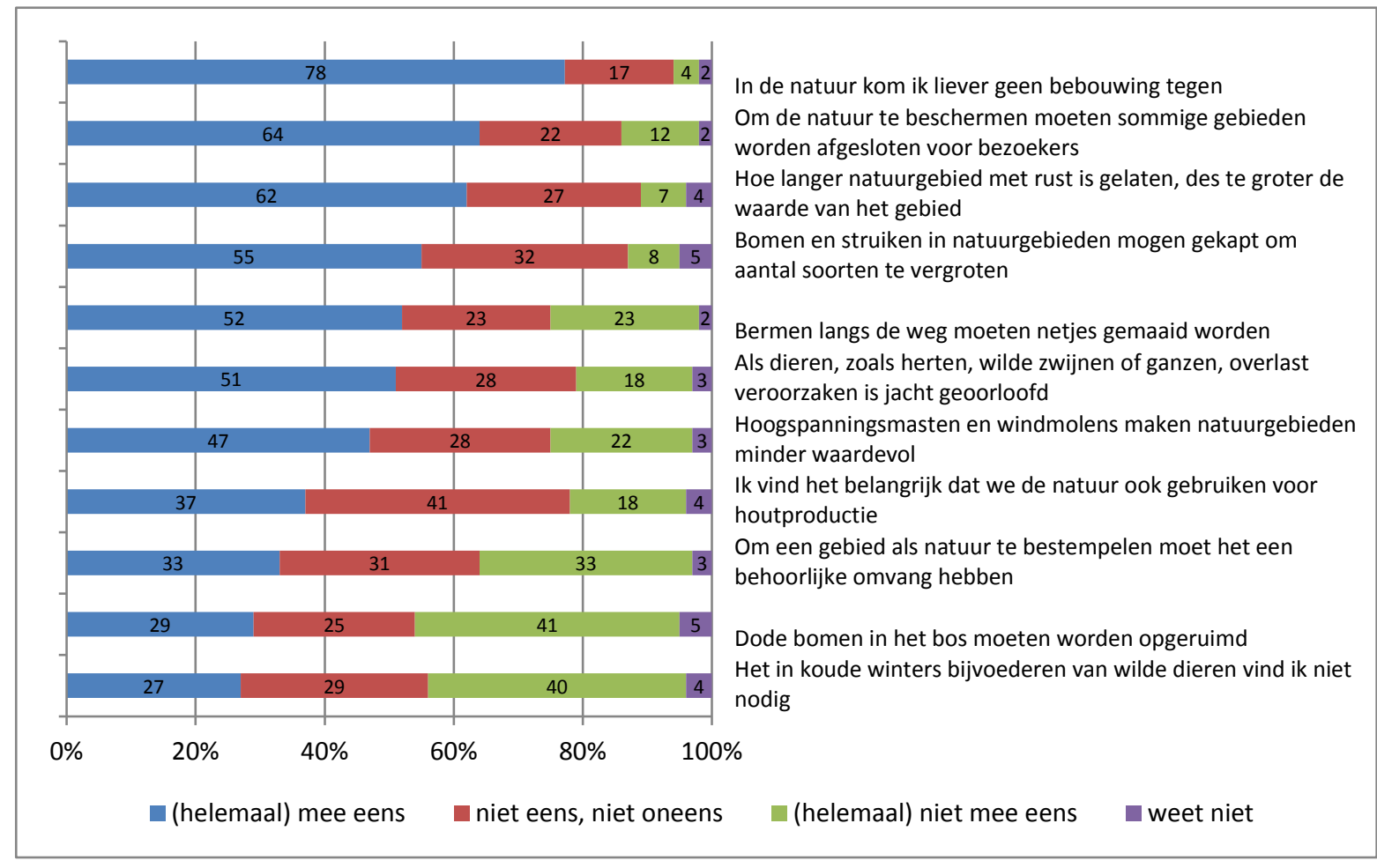

Figuur 4.9 Mening over het ingrijpen van de mens in de natuur (\%).

Mannen zijn het meer dan vrouwen eens met de uitspraken 'Hoe langer...' en 'Bomen en struiken...'. Ouderen zijn het meer dan andere leeftijdsgroepen eens met de uitspraak 'In de natuur...', terwijl de middenleeftijdsgroep (35-55 jaar) het meest positief is over de uitspraken 'Om de natuur...' en 'Bomen en struiken...'. Jongeren hechten meer dan ouderen aan het maaien van bermen. Opleidingsniveau doet ertoe voor alle vijf de belangrijkste uitspraken. Lager opgeleiden zijn het meer dan hogeropgeleiden eens met de uitspraken 'Hoe langer...', 'In de natuur...' en 'Bermen... '. Hoogopgeleiden hechten juist meer aan de uitspraken 'Om de natuur...' en 'Bomen en struiken...'. Tot slot zijn allochtonen het vaker eens met de uitspraak over bermen dan autochtonen. Samengevat zijn mannen, ouderen en autochtonen minder voor menselijk ingrijpen.

\subsubsection{Vergelijking met eerdere jaren}

In 2013 zijn dezelfde elf stellingen voorgelegd, acht daarvan zijn ook in 2006 bevraagd. In 2001 zijn zes deels vergelijkbare stellingen opgenomen. Alle zes formuleringen weken enigszins af van de items in de latere versies. Het gaat om de 2001-items:

- Als ik aan het wandelen ben in de natuur kom ik liever geen bebouwing tegen;

- Naarmate een natuurgebied langer door de mens met rust is gelaten, neemt de waarde van dat gebied toe;

- Van mij hoeven ze het gras in de wegbermen en langs sloten nooit te maaien;

- Hoogspanningsmasten of moderne windmolens maken natuurgebieden minder waardevol;

- Om een gebied als natuur te bestempelen moet het een behoorlijke omvang hebben (bijv. minimaal $1 \times 1 \mathrm{~km}$ );

- Dode bomen en struiken in bossen en natuurgebieden moeten opgeruimd en weggehaald worden. 
Figuur 4.10 geeft het percentage Nederlanders weer dat het (helemaal) eens is met de stellingen. De figuur laat allereerst zien dat het aandeel mensen dat zich kan vinden in een stelling onderling sterk varieert. Dat zegt niet veel, want hangt grotendeels samen met de formulering van de boodschap (voor of tegen menselijke ingrijpen). In relatie tot de analyse in de tijd valt op dat er door de jaren heen wat lichte schommelingen zijn in het denken over de omgang met natuur. Kijken we wat beter ook naar de richting van de stellingen: voor of tegen zichtbare menselijke invloeden- dan valt de tendens op dat het publiek een sterkere wens uit naar natuur waar de menselijke invloed gering is. Dit zien we met name terug in het item dat de meeste bijval van het publiek krijgt. In 2001 wilde 76\% van het publiek liever geen bebouwing in de natuur, dit aandeel zakte naar 68\% (2006) en verder naar $61 \%$ (2013), waarna nu weer de grote meerderheid (78\%) blijk geeft van een voorkeur voor geen bebouwing. Ook vindt een groeiend aandeel Nederlanders dat de waarde van een natuurgebied toeneemt, als dat door mensen met rust wordt gelaten; van 57\% in 2006 naar 62\% in 2017, waarbij het percentage Nederlanders van 2001 (78\%) overigens nog ver weg lijkt. Ook in relatie tot bomen kappen (58\% in 2013, 54\% in 2017) en bijvoederen van dieren (19\% in 2006, 26\% in 2017) is een lichte verschuiving zichtbaar richting de beheervisie van 'handen af van de natuur'. Geen verandering in de tijd geven vier van de 11 stellingen, stabiel is het denken over het afsluiten van gebieden, het maaien van bermen langs de weg, de impact van hoogspanningsmasten en de jacht.

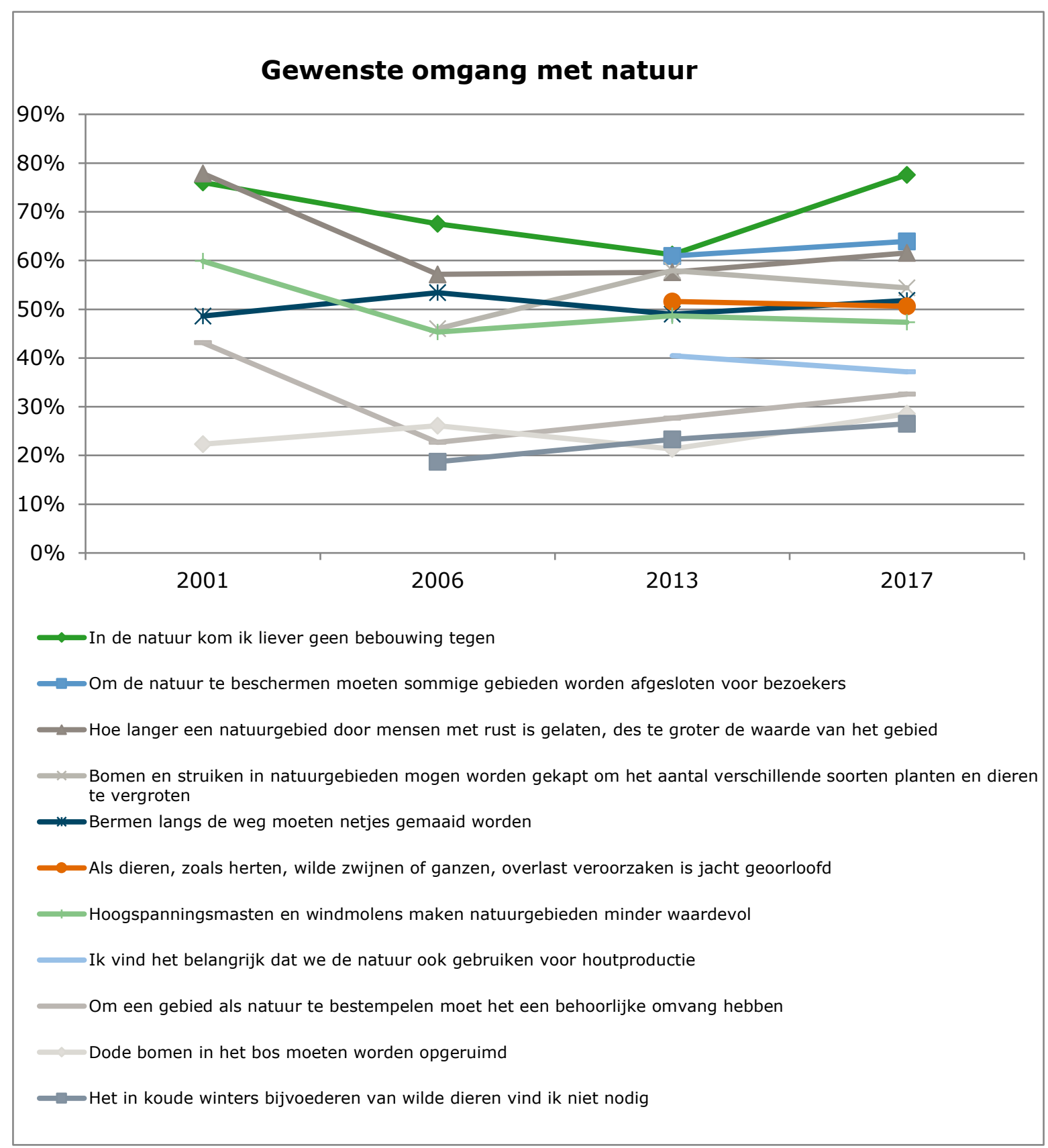

Figuur 4.10 Percentage Nederlanders dat het (helemaal) eens is met de stellingen over natuurbeheer in 2001, 2006, 2013 en 2017 
De stelling over bermen langs de weg was in 2001 gespiegeld geformuleerd. In de figuur is hiervoor gecorrigeerd door in 2001 het percentage (helemaal) mee oneens weer te geven.

\subsection{Waardering van de hoeveelheid natur}

\subsubsection{Landelijk beeld}

Een meerderheid van de Nederlandse bevolking is tevreden over de hoeveelheid groen in de woonomgeving en in Nederland. Respectievelijk 78 en $63 \%$ van de Nederlandse bevolking vindt dit (ruim) voldoende. Een derde vindt de hoeveelheid groen in Nederland (te) weinig. Het groen in de woonomgeving vindt een vijfde te weinig (zie tabel 4.4).

Tabel 4.4 Mening over de hoeveelheid natuur in de woonomgeving en in Nederland.

\begin{tabular}{lrr} 
& In woonomgeving & In Nederland \\
Te weinig & 8 & 12 \\
\hline Weinig & 14 & 22 \\
\hline Voldoende & 53 & 54 \\
\hline Ruim voldoende & 25 & 9 \\
\hline Te veel & 0 & 0 \\
Weet niet & 1 & 3
\end{tabular}

De mate van tevredenheid over de hoeveelheid groen verschilt tussen de vier grote steden (Amsterdam, Rotterdam, Den Haag en Utrecht) en overig Nederland. Van de inwoners van de vier grote steden vindt $58 \%$ de hoeveelheid natuur in de woonomgeving (ruim) voldoende en $41 \%$ vindt het (te) weinig; voor overig Nederland is dit respectievelijk $81 \%$ en $18 \%$. Wat betreft de waardering van de hoeveelheid groen in Nederland is het verschil tussen de vier grote steden en overig Nederland kleiner, respectievelijk $51 \%$ en $65 \%$ vindt dit (ruim) voldoende (figuur 4.11 ).

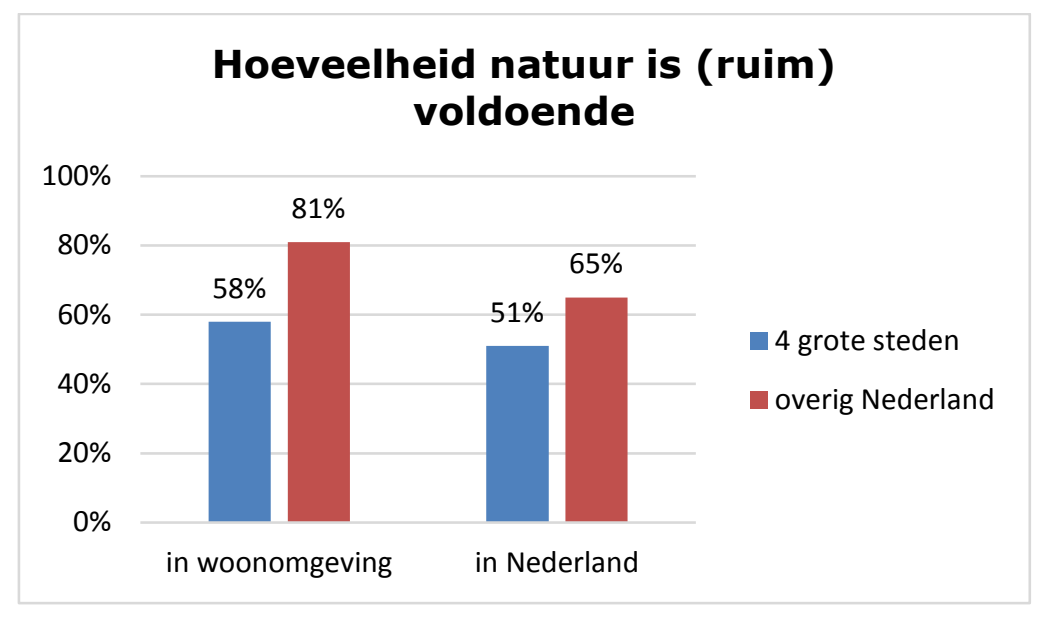

Figuur 4.11 Waardering hoeveelheid natuur in de woonomgeving en in Nederland naar stedelijkheid.

Ouderen (55-75 jaar) beoordelen de hoeveelheid natuur in de woonomgeving als meer dan andere leeftijdsgroepen. Allochtonen ervaren de hoeveelheid natuur in Nederland als meer dan autochtonen en niet-stedelingen ervaren zowel de hoeveelheid natuur in Nederland als in de woonomgeving als meer. Dit laatste ligt voor de hand, want hangt samen met de minder stedelijke omgeving waarin zij wonen.

\subsubsection{Provincies}

Inwoners van Zuid-Holland zijn het minst tevreden of de hoeveelheid groen in de woonomgeving $(65 \%)$. Het meest tevreden zijn inwoners uit Overijssel (88\%). Wat betreft de hoeveelheid groen in Nederland lopen de scores op (ruim) voldoende van $42 \%$ (Drenthe) tot $60 \%$ (Groningen), zie figuur 4.12 . 


\subsubsection{Vergelijking met eerdere jaren}

In 2017 zijn exact dezelfde twee vragen gesteld over de hoeveelheid natuur in Nederland en in de woonomgeving als in 2006 en 2013. Dit maakt een vergelijking tussen de drie jaren goed mogelijk. In 2001 zijn deze vragen ook gesteld, maar de antwoordcategorieën weken af: (heel) veel, neutraal en (heel) weinig. Deze andere formulering maakt dat de bevindingen uit 2001 niet goed vergelijkbaar zijn met latere jaren, immers weinig natuur kan nog steeds voldoende zijn in de ogen van het publiek. Vanwege de lastige interpretatie zijn de bevindingen uit 2001 niet in figuur 4.13 opgenomen. Er is geen soortgelijke vraag gesteld in 1996.

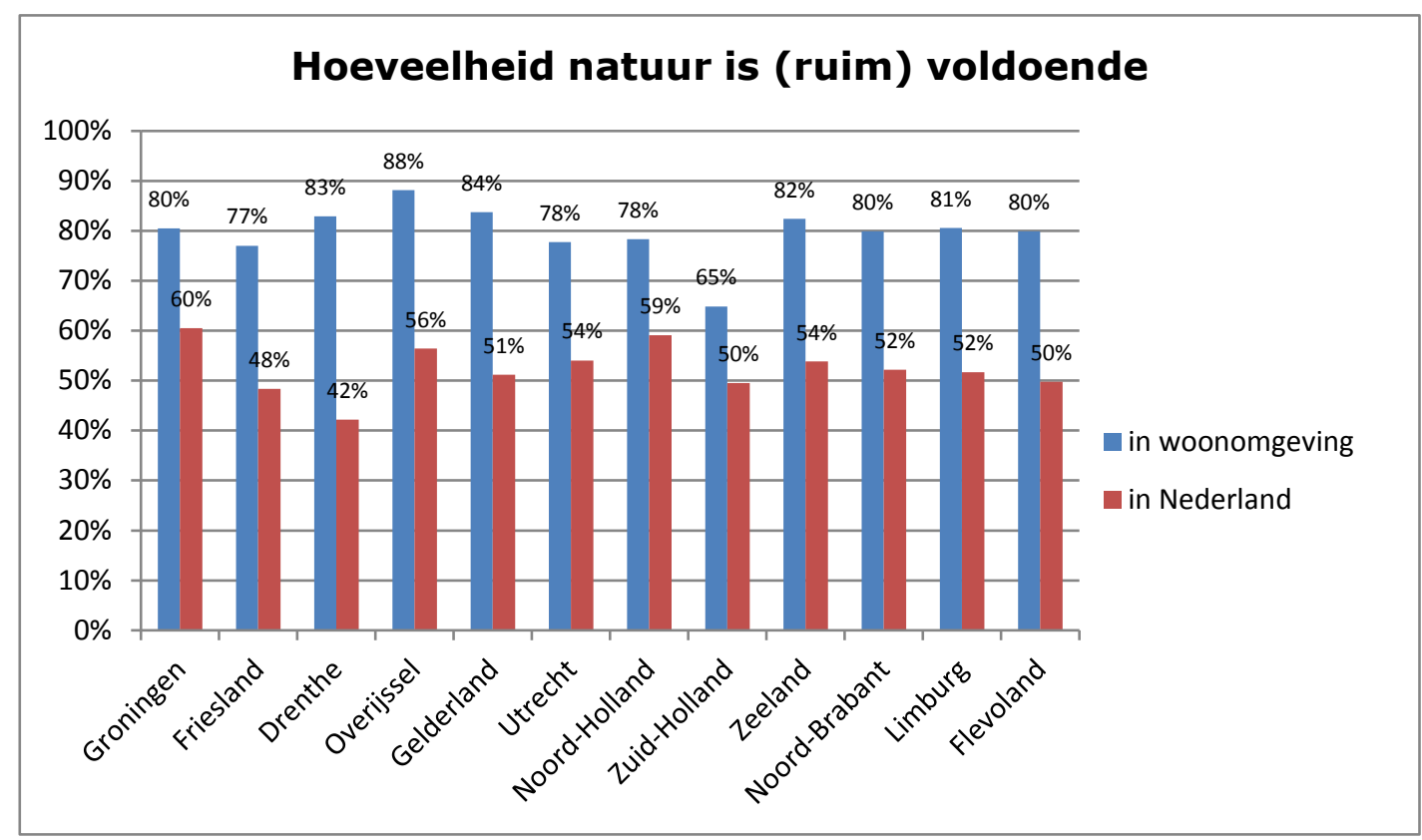

Figuur 4.12 Percentage tevredenen met groen in woonomgeving en groen per provincie.

In figuur 4.13 zijn de percentages Nederlanders weergegeven die de hoeveelheid natuur als voldoende of ruim voldoende ervaren. Uit de figuur blijkt dat het publiek in 2017 iets minder tevreden is over de hoeveelheid natuur in Nederland dan in 2013, maar nog altijd positiever dan in 2006. In 2017 vond $63 \%$ dit (ruim) voldoende en in 2013 was dit 67\%. In 2006 was niet meer dan 47\% tevreden over de hoeveelheid natuur in Nederland. Voor wat betreft de waardering van de hoeveelheid natuur in de woonomgeving is er geen (significant, zie bijlage 4) verschil tussen 2013 en 2017; de grote lijn is daarmee dat tussen 2006 en 2013 de tevredenheid over de hoeveelheid groen in de woonomgeving is toegenomen van 67\% naar net onder de $80 \%$ en dat dit tussen 2013 en 2017 stabiel is gebleven.

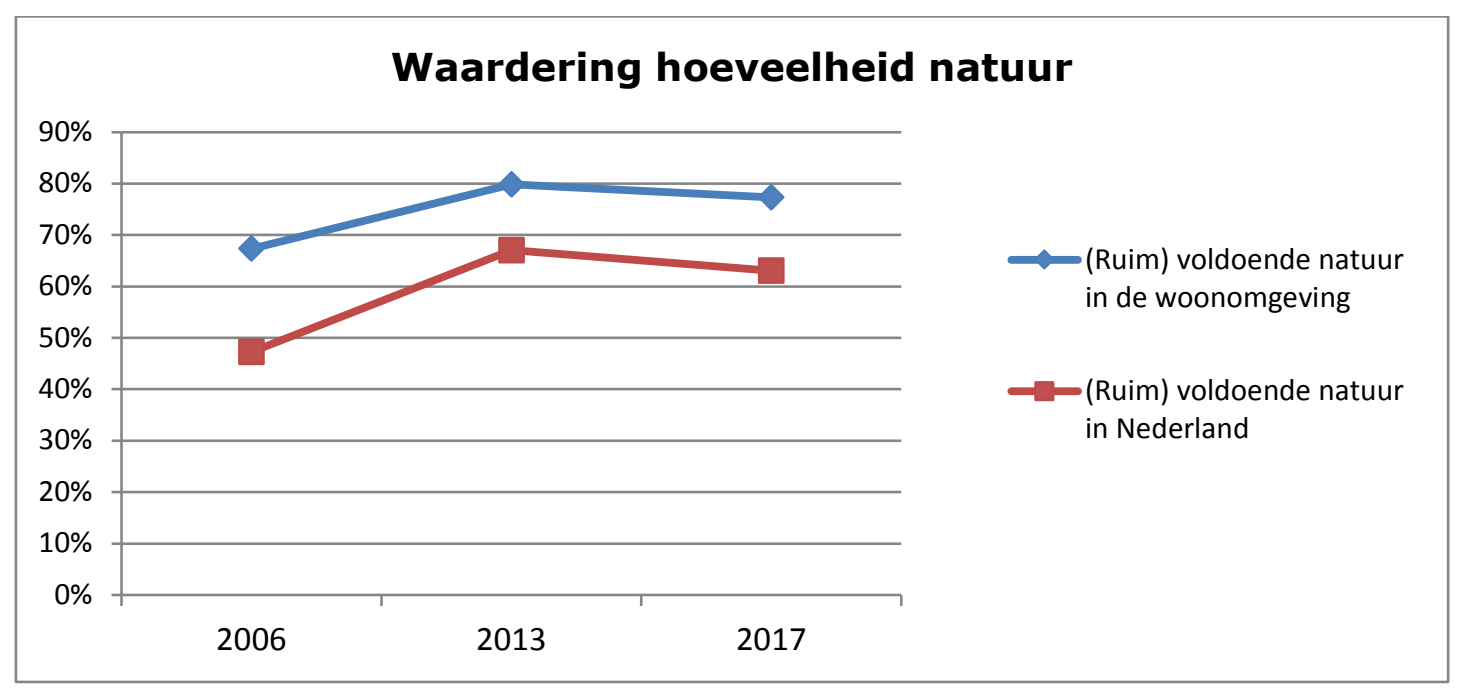

Figuur 4.13 Percentage Nederlanders dat de hoeveelheid natuur in Nederland en in de eigen woningomgeving als (ruim) voldoende ervaart in 2006, 2013 en 2017 
Een vergelijking van de ontwikkelingen in de tevredenheid over de natuur (figuur 4.13) met de eerdere bevindingen uit dit hoofdstuk laat een opvallende samenhang zien. De grote lijn is dat het belang dat de bevolking hecht aan natuurbehoud (probleembesef, maatregelen in natuurbeheer en tot op zekere hoogte ook de dilemma's economie-natuur) tot 2013 daalde en tussen 2013 en 2017 weer een opgaande lijn vertoont. De tevredenheid over de hoeveelheid natuur is in 2013 juist op zijn hoogst. Het lijkt er dus op dat mensen positiever (tevredener) zijn over de hoeveelheid natuur op het moment dat ze minder belang hechten aan natuurbehoud. En omgekeerd zijn ze dus kritischer over de hoeveelheid natuur als ze veel waarde hechten aan natuurbehoud. 



\section{$5 \quad$ Steun voor natuurbeleid}

\section{$5.1 \quad$ Inleiding}

De steun voor het natuurbeleid is op verschillende wijzen in kaart gebracht. We gaan eerst in op het belang van natuur ten opzichte van andere beleidsthema's. Daarna komt de mening van de bevolking over de verantwoordelijke actoren voor natuur aan de orde. Tot slot gaan we in op het belang van verschillende beleidsmaatregelen voor natuur.

\subsection{Belang van natuurbeleid t.o.v. andere beleidsvelden}

\subsubsection{Landelijk beeld}

Om een beeld te krijgen van het maatschappelijk draagvlak voor natuurbeleid is het nuttig om te weten welke positie dit beleid inneemt ten opzichte van andere beleidsthema's. Aan de Nederlandse bevolking zijn tien beleidsterreinen voorgelegd en is gevraagd welke vier voor de overheid het meest belangrijk zouden moeten zijn. In tabel 5.1 staan de resultaten.

Tabel 5.1 Belangrijkste beleidsthema's van de overheid (\%)

\begin{tabular}{lr} 
Beleidsterreinen & $\%$ \\
Gezondheidszorg & 75 \\
Onderwijs & 51 \\
Werkgelegenheid & 44 \\
Misdaad en terrorisme & 44 \\
Sociale zekerheid & 41 \\
Milieu en klimaat & 37 \\
Ouderen & 32 \\
Normen en waarden & 25 \\
Immigratie en integratie & 24 \\
Natuur & 14 \\
Geen van deze & 1 \\
\hline
\end{tabular}

De gezondheidszorg vindt $75 \%$ van de burgers het belangrijkste beleidsthema van de rijksoverheid. Op afstand gevolgd door de thema's onderwijs (51\%), werkgelegenheid (44\%), misdaad en terrorisme (44\%) en sociale zekerheid (41\%). Het beleidsthema natuur staat onderaan. $14 \%$ van de burgers vindt dit het belangrijkste thema.

Vrouwen hechten meer dan mannen aan aandacht van de overheid voor gezondheidszorg, mannen vinden sociale zekerheid belangrijker dan vrouwen. De middenleeftijdsgroep (35-55 jarigen) hechten meer dan andere leeftijden aan gezondheidszorg en sociale zekerheid. Jongeren vinden onderwijs belangrijker dan ouderen en ook werkgelegenheid is voor jongeren (tot 35 jaar) een meer prioritair onderwerp. Laagopgeleiden vinden misdaad en terrorismebestrijding belangrijker dan hoger opgeleiden, hoger opgeleiden hechten juist meer dan gemiddeld aan onderwijs als overheidsthema. Voor de prioritering van het onderwerp natuur doen zich geen significante verschillen voor tussen groepen met andere achtergrondkenmerken. 


\subsubsection{Vergelijking met eerdere jaren}

In eerdere jaren is de vraag over prioritaire overheidsonderwerpen ook gesteld, wel zijn de vraagformulering en bevraagde thema's in 2017 enigszins aangepast ten opzichte van de 2013-versie: Rijksoverheid is veranderd in overheid (vraagformulering), het onderwerp immigratie en integratie heette voorheen allochtonen en het onderwerp milieu en klimaat heette voorheen milieu- en luchtvervuiling. In 2013 is exact dezelfde vraag gesteld als in 2006. In 2001 is deze vraag voor het eerst gesteld; de bevraagde maatschappelijke onderwerpen zijn tussen 2001 en 2006 grotendeels veranderd. De vijf onderwerpen uit 2001 die ook in 2017 zijn gesteld zijn in de analyse meegenomen.

Figuur 5.1 geeft de verschuivingen in de tijd van prioritaire onderwerpen van het overheidsbeleid weer volgens de Nederlandse bevolking. Een aantal zaken valt op. Zo blijkt gezondheidszorg in alle jaren onverminderd het meest genoemd te zijn en ook onderwijs is door de jaren heen almaar door de meerderheid van het publiek aangekruist. Verder is werkgelegenheid in 2017 als beleidsonderwerp sterk afgenomen en weer rond het niveau van 2006 (circa 45\%). De piek van 2013 (72\%) lijkt samen te hangen met de omvang van de economische crisis destijds. Opvallend is voorts dat het belang van immigratie en integratie sterk is toegenomen tussen 2013-2017. Mogelijk ligt een deel van de verklaring in de andere naamgeving.

Een andere opvallende stijging doet zich voor bij het onderwerp milieu en klimaat. Ook dit onderwerp heette voorheen anders en dat zou een deel van de verklaring kunnen vormen. Tot slot valt op dat het onderwerp natuur is gekelderd in belang: waar in 2006 en 2013 nog circa 1 op de 5 mensen dit een prioritair onderwerp vond, is dat in 2017 gezakt naar 14\%. In vergelijking tot 2001 (56\%) oogt de afname desastreus. Daarbij moet worden opgemerkt dat het lijstje van onderwerpen in dat jaar grotendeels afweek van latere jaren, wat invloed kan hebben en daarmee de interpretatie van de 2001-bevindingen lastig maakt. Normen en waarden is het enige onderwerp dat geen significante verandering in de tijd laat zien (zie ook bijlage 4).

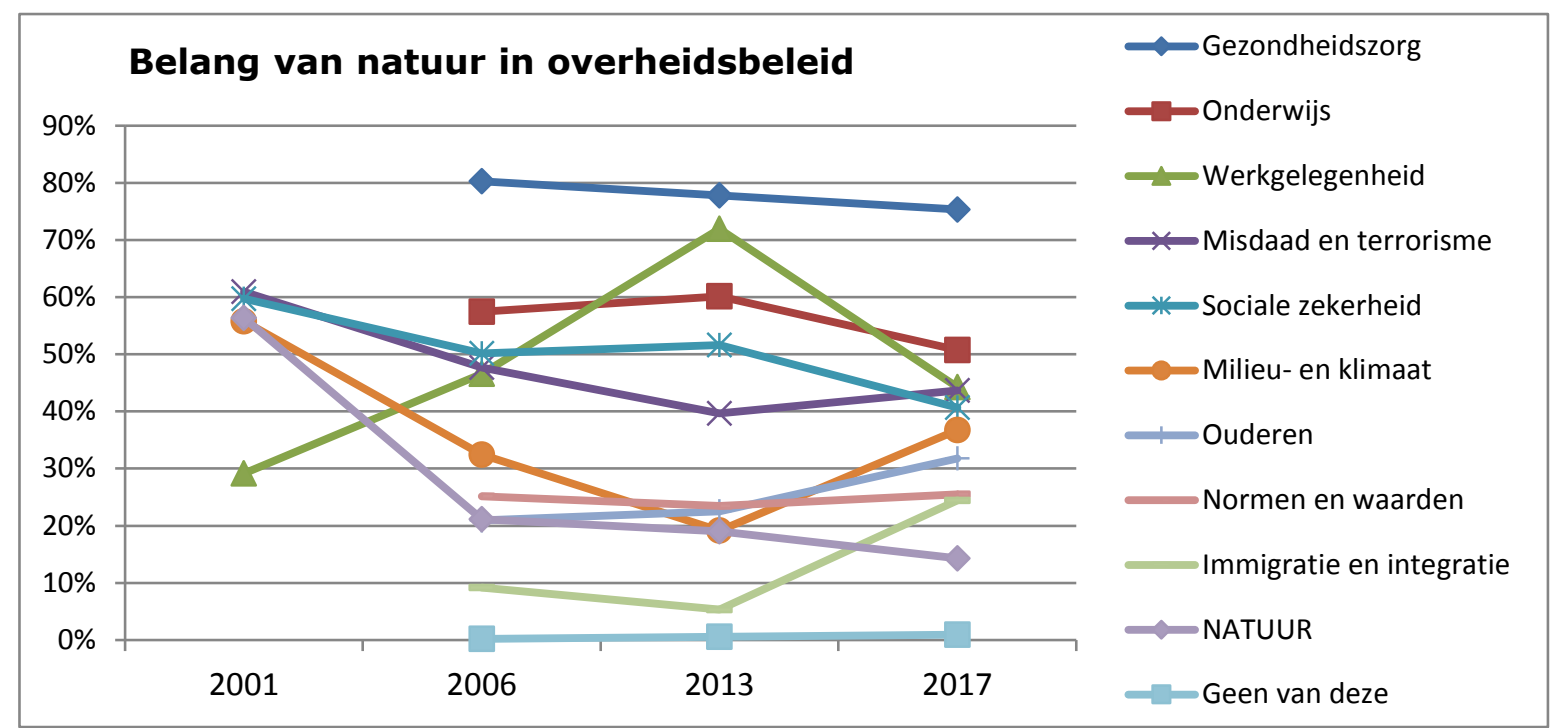

Figuur 5.1 Percentage Nederlanders dat het onderwerp noemt als één van de vier onderwerpen die de grootste prioriteit van de overheid moeten zijn, in 2001, 2006, 2013 en 2017

\subsection{Welke actoren zijn verantwoordelijk voor natuur in natuurgebieden, op het platteland en in de stad?}

\subsubsection{Landelijk beeld}

Aan de Nederlandse bevolking is gevraagd in hoeverre partijen als de overheid, landbouwbedrijven, natuurorganisaties, overig bedrijfsleven en burgers verantwoordelijkheid voor natuur moeten dragen. Dit is per categorie (natuurgebied, platteland en stad) en per actor gevraagd. 
De overheid is volgens twee derde van de burgers hoofdverantwoordelijk voor natuur in natuurgebieden. Een vijfde van de bevolking vindt natuurorganisaties hoofdverantwoordelijk. De landbouwbedrijven en de burgers wordt door respectievelijk $81 \%$ en $79 \%$ als medeverantwoordelijke gezien, gevolgd door overig bedrijfsleven en natuurorganisaties, zie figuur 5.2.

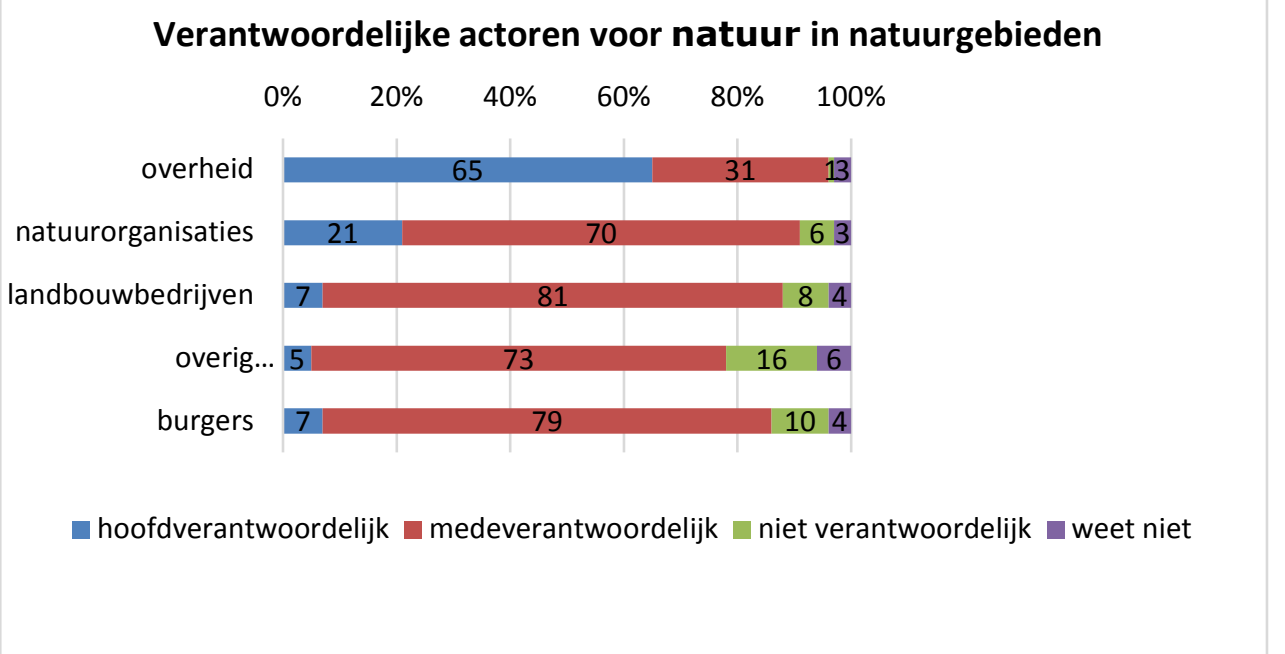

Figuur 5.2 Mate van verantwoordelijkheid van actoren voor natuur in natuurgebieden (\%)

Mannen zien de overheid als meer verantwoordelijk voor natuur in natuurgebieden dan vrouwen, vrouwen zien een grotere verantwoordelijkheid bij natuurorganisaties, overig bedrijfsleven en burgers dan mannen. Waar jongeren meer dan andere leeftijden de overheid als verantwoordelijk zien, vinden ouderen meer dan jongeren dat de verantwoordelijkheid bij natuurorganisaties en burgers ligt. Ook hoogopgeleiden vinden meer dan lager opgeleiden dat de verantwoordelijkheid bij de overheid ligt, lager opgeleiden zien meer dan hoger opgeleiden de verantwoordelijkheid bij landbouw, overig bedrijfsleven en burgers.

Ook voor de natuur op het platteland is de overheid hoofdverantwoordelijk volgens een meerderheid van de bevolking (54\%) en ruim een derde vindt de landbouwbedrijven hoofdverantwoordelijk. Alle andere actoren worden door minimaal twee derde van de burgers als medeverantwoordelijk gezien, zie figuur 5.3 .

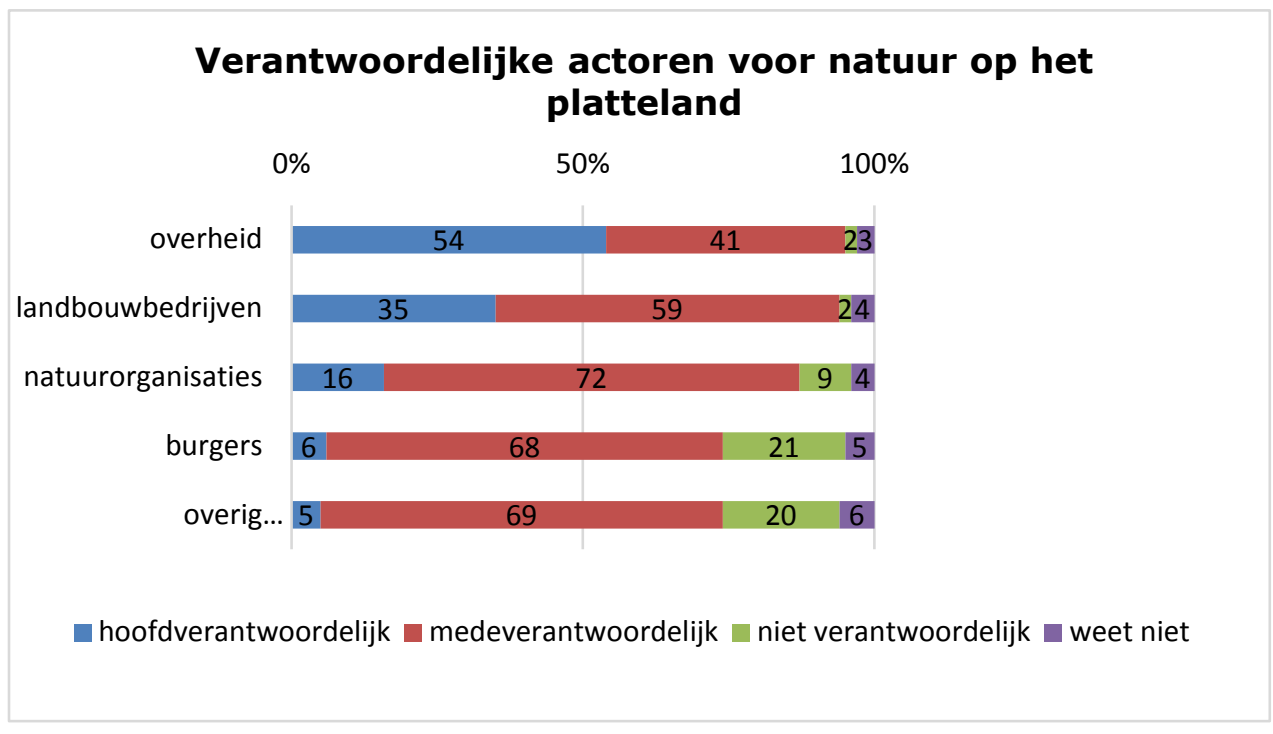

Figuur 5.3 Mate van verantwoordelijkheid van actoren voor natuur op het platteland (\%)

Voor natuur op het platteland vinden opnieuw mannen de overheid meer verantwoordelijk dan vrouwen, vrouwen leggen de verantwoordelijkheid meer dan mannen neer bij natuurorganisaties, overig bedrijfsleven en burgers. Jongere leeftijdsgroepen (tot 35 jaar) zien meer verantwoordelijkheid 
bij de overheid in vergelijking tot ouderen, ouderen dichten juist natuurorganisaties en burgers meer verantwoordelijkheid toe dan jongeren. Hoogopgeleiden beschouwen de overheid meer dan lager opgeleiden als verantwoordelijk, lager opgeleiden zien die rol meer dan hoger opgeleiden weggelegd bij natuurorganisaties, overig bedrijfsleven en burgers. Autochtonen zien meer dan allochtonen verantwoordelijkheid liggen bij de overheid en bij burgers. Stedelingen hechten meer aan de overheid dan niet-stedelingen, terwijl niet-stedelingen meer dan stedelingen natuurorganisaties als verantwoordelijk zien.

Wat betreft natuur in de stad ziet ook een ruime meerderheid (69\%) de overheid als hoofdverantwoordelijke. Natuurorganisaties, burgers en overig bedrijfsleven zijn volgens de burgers in hoge mate medeverantwoordelijk (figuur 5.4).

\section{Verantwoordelijke actoren voor natuur in de stad}

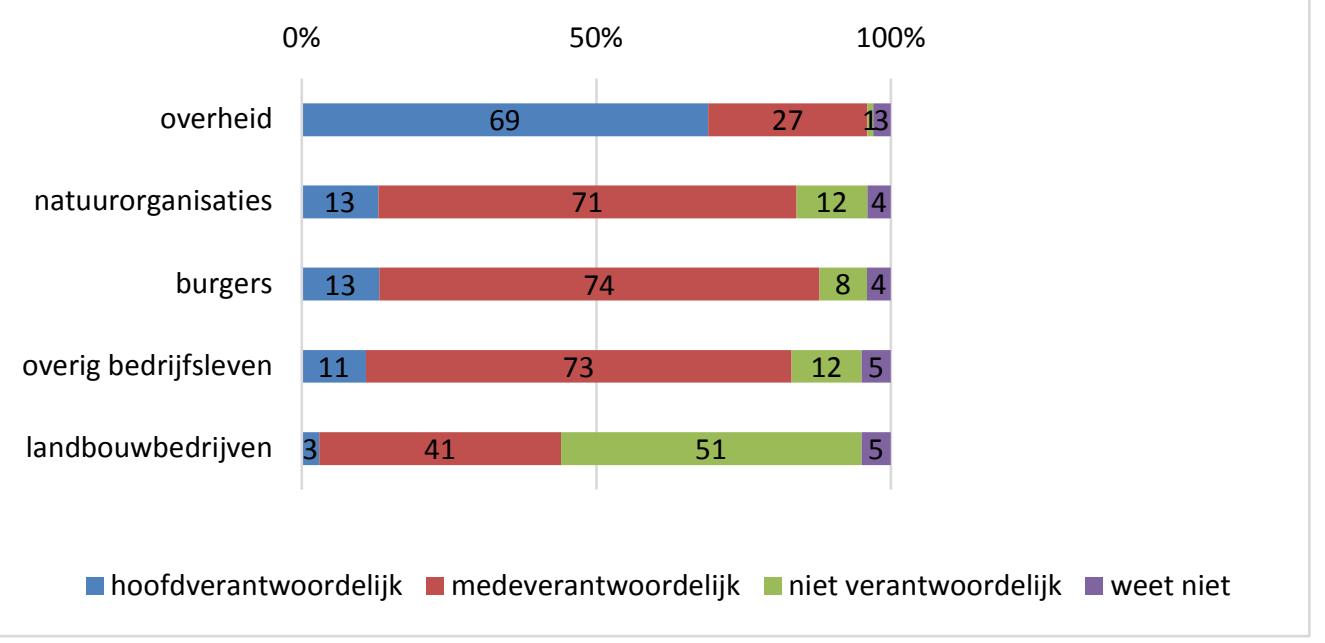

Figuur 5.4 Mate van verantwoordelijkheid van actoren voor natuur in de stad (\%)

Ook als het gaat om natuur in de stad verschillen opvattingen onder invloed van achtergrondkenmerken. Mannen zien die meer dan vrouwen bij de overheid liggen, vrouwen zien meer dan mannen een rol voor landbouwbedrijven, natuurorganisaties en overig bedrijfsleven. Jongeren vinden meer dan ouderen landbouwbedrijven en overig bedrijfsleven verantwoordelijk en voor burgers geldt het omgekeerde: ouderen hechten meer aan hun verantwoordelijkheid dan jongeren. Opnieuw vinden hoger opgeleiden meer dan lager opgeleiden dat de overheid verantwoordelijk is, terwijl lager opgeleiden meer dan hoger opgeleiden een rol zien voor landbouwbedrijven en natuurorganisaties. Allochtonen hechten meer dan autochtonen aan landbouwbedrijven en overig bedrijfsleven. Tot slot zien stedelingen meer dan niet-stedelingen een rol voor de overheid.

Samenvattend kunnen we stellen dat de overheid als belangrijkste hoofdverantwoordelijke voor natuur wordt gezien, zowel in natuurgebieden, stad als platteland. De andere actoren vindt men echter in hoge mate medeverantwoordelijk.

\subsubsection{Vergelijking met eerdere jaren}

De vraag over verantwoordelijke actoren is ook in 2013 gesteld; toen werd echter geen onderscheid gemaakt naar typen natuurgebieden, maar in zijn algemeenheid gevraagd welke partijen verantwoordelijkheid voor natuur moeten dragen. Daarnaast kon men in 2013 maar één actor als hoofdverantwoordelijk aankruisen, in 2017 kunnen meer actoren hoofdverantwoordelijk zijn. Ook de naamgeving van partijen is aangepast. Landbouwbedrijven heette in 2013 landbouw, natuurorganisaties heette in 2013 natuurbeschermingsorganisaties en overig bedrijfsleven kwam als categorie niet voor. In plaats daarvan waren twee andere categorieën opgenomen: toeristische ondernemers en projectontwikkelaars. In 2006 werden de respondenten gevraagd hun mening te geven over een aantal uitspraken over wie meer verantwoordelijkheid voor de natuur kon nemen en in 1996 is gevraagd of men de actoren overheid, landbouw, bedrijfsleven en individuele burgers 
verantwoordelijk acht voor het beschermen van natuur (met als antwoordmogelijkheden 'ja', 'ja enigszins', 'nee' en 'weet niet'). Door de andere vraagstelling in 2006 en 1996 zijn deze antwoorden niet vergelijkbaar met die van 2017. In 2001 is geen vraag opgenomen over dit onderwerp.

Om de opvattingen van het publiek tussen 2013 en 2017 te kunnen vergelijken, zijn de resultaten van 2017 geaggregeerd en wel door de landelijke bevindingen voor de drie in 2017 bevraagde typen natuur (in natuurgebieden, in het platteland en in de stad) te middelen. Deze berekening benadert de 2013-vraagstelling het beste, omdat het aannemelijk is dat ook de respondent uit 2013 deze drie typen natuur voor ogen had. Immers in de vragenlijst van 2013 werd benadrukt dat natuur breed moet worden opgevat en al bij een eerdere vraag in de 2013-enquête over bezoekgedrag zijn ook deze drie typen natuurgebieden onderscheiden. De score van bedrijfsleven is voor 2013 gebaseerd op de antwoorden voor (1) toeristische ondernemers en (2) projectontwikkelaars. Indien de respondent minimaal één van beide partijen als hoofdverantwoordelijke noemt, dan wordt dit opgevat als bedrijfsleven is hoofdverantwoordelijk. Indien de respondent minimaal één van beide partijen als medeverantwoordelijke noemt én de ander NIET als hoofdverantwoordelijke, dan wordt dit opgevat als bedrijfsleven is medeverantwoordelijk. Hoofdverantwoordelijk is dus dominant over medeverantwoordelijk.

Voor de vergelijking tussen beide jaren is het belangrijk om de bevindingen over actoren die als hoofd-, mede- en niet-verantwoordelijk worden genoemd, in samenhang te beschouwen. In figuur 5.5 zijn de drie figuren weergegeven.

Uit figuur 5.5A blijkt dat de meerderheid van de Nederlanders de overheid als hoofd-verantwoordelijke beschouwt voor natuur in Nederland en dat dit aandeel tussen 2013 en 2017 licht is toegenomen ${ }^{3}$ : van 60 naar $63 \%$. De grootste groei is zichtbaar bij de natuurorganisaties en het bedrijfsleven. Verder zien we dat in 2017, ten opzichte van 2013, ook alle andere partijen in hoofdverantwoordelijkheid zijn gegroeid. Dit zou echter te maken kunnen hebben met het feit dat in 2017 respondenten meerdere partijen als hoofdverantwoordelijk konden aankruisen en dat ook hebben gedaan, waar dit in 2013 niet mogelijk was.

Een andere kanttekening bij de figuur is dat de nuancerende vraagstelling van 2017 de veranderingen deels zou kunnen verklaren. Door in 2017 te vragen naar natuur op het platteland en in natuurgebieden, ligt de link naar respectievelijk landbouwbedrijven en natuurorganisaties vrij voor de hand. In de vorige paragraaf werd duidelijk dat deze twee actoren voor deze gebieden er inderdaad uitspringen als hoofdverantwoordelijke: $35 \%$ van de Nederlanders ziet de landbouw als hoofdverantwoordelijke voor natuur op het platteland en $21 \%$ van de Nederlanders natuurorganisaties als hoofdverantwoordelijke voor natuurgebieden. In 2013 was de vraagstelling veel minder sturend naar een bepaalde actor. Dat zou (deels) een verklaring kunnen zijn voor de toename voor deze twee actoren.

In figuur 5.5B is weergegeven hoe het publiek denkt over medeverantwoordelijkheid. Medeverantwoordelijkheid is een belangrijk thema binnen het natuurbeleid van de overheid en het is daarom aardig om stil te staan bij hoe burgers hierover denken. De figuur laat zien dat een ruime meerderheid van de Nederlandse bevolking andere partijen -burgers, het bedrijfsleven, natuurorganisaties en agrariërs- als medeverantwoordelijk ziet voor natuurbescherming in Nederland. De dalende lijn voor alle actoren tussen 2013 en 2017 houdt verband met het vaker noemen van de actoren als hoofdverantwoordelijke, maar kan de grote terugnames (landbouwbedrijven van $90 \%$ naar $60 \%$, bedrijfsleven van $87 \%$ naar $72 \%$, burgers van $86 \%$ naar $74 \%$ ) niet in zijn geheel verklaren.

De laatste figuur gaat over niet-verantwoordelijke actoren. Figuur 5.5C maakt duidelijk dat het publiek in 2017 vaker aangeeft dat de bevraagde actoren niet verantwoordelijk zijn. Dat geldt het sterkst voor landbouwbedrijven ( $4 \%$ in $2013,20 \%$ in 2017), en ook voor het bedrijfsleven ( $8 \%$ in $2013,16 \%$ in 2017) en burgers: $6 \%$ in 2013, 13\% in 2017. Alles overziend, lijkt het publiek ten opzichte van 2013 minder verantwoordelijkheid voor natuur bij maatschappelijke actoren te leggen.

\footnotetext{
${ }^{3}$ Waarschijnlijk gaat het om significante verschillen, gezien de procentuele verschillen én de omvang van de datasets. Dit kon echter voor deze vraag niet statistisch getoetst worden, vanwege de afwijkende vraagstelling tussen 2013 en 2017.
} 

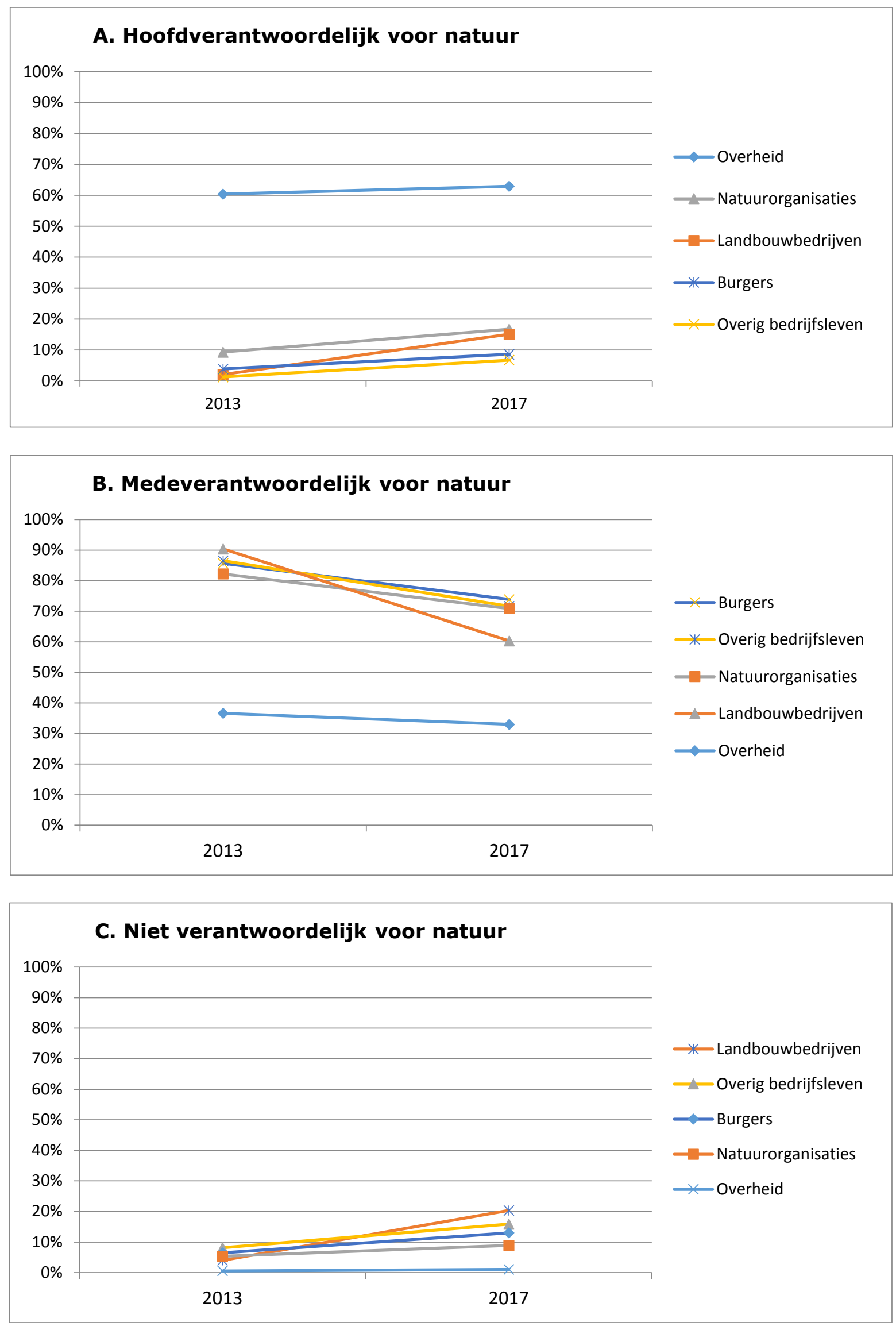

Figuur 5.5 Percentage Nederlanders dat de actor ziet als hoofdverantwoordelijk (A), medeverantwoordelijk (B) en niet verantwoordelijk (C) voor natuur in 2013 en 2017 


\subsection{Belang van maatregelen om natuur te beschermen}

\subsubsection{Landelijk beeld}

Het natuurbeleid is zeer divers en bestaat uit verschillende onderdelen. Aan de Nederlandse bevolking is daarom een aantal beleidsmaatregelen voorgelegd. Allereerst hebben de burgers van alle maatregelen apart aangegeven hoe belangrijk men die vindt en vervolgens is gevraagd wat men de drie belangrijkste maatregelen vindt.

De burgers vinden het beschermen van bestaande natuurgebieden (zeer) belangrijk (94\%), gevolgd door het beheren en onderhouden van natuurgebieden (93\%), beschermen van zeldzame planten en dieren en bijzondere gebieden (91\%) en het beschermen van natuur op het platteland (89\%). Meer voorzieningen (paden, bankjes) vindt men het minst belangrijk (53\%), zie tabel 5.2 .

Tabel 5.2 Mening over maatregelen om natuur te beheren en te verbeteren (\%)

\begin{tabular}{|c|c|c|c|c|}
\hline Stellingen & $\begin{array}{l}\text { (zeer) } \\
\text { belangrijk }\end{array}$ & $\begin{array}{l}\text { niet belang- } \\
\text { rijk, niet } \\
\text { onbelangrijk }\end{array}$ & $\begin{array}{l}\text { (helemaal) } \\
\text { niet } \\
\text { belangrijk }\end{array}$ & weet ik niet \\
\hline Beschermen van bestaande natuurgebieden & 94 & 5 & 0 & 1 \\
\hline Het beheren en onderhouden van natuurgebieden & 93 & 5 & 1 & 1 \\
\hline \multicolumn{5}{|l|}{ Beschermen van zeldzame planten, dieren en } \\
\hline bijzondere gebieden & 91 & 7 & 1 & 1 \\
\hline Beschermen van natuur op het platteland & 89 & 8 & 1 & 1 \\
\hline \multicolumn{5}{|l|}{ Bedrijven betrekken bij het beschermen en } \\
\hline verbeteren van de natuur & 85 & 11 & 3 & 1 \\
\hline Meer natuureducatie op scholen & 83 & 14 & 1 & 2 \\
\hline \multicolumn{5}{|l|}{ Burgers betrekken bij het beschermen en verbeteren } \\
\hline van de natuur & 81 & 16 & 2 & 1 \\
\hline Aanleg en/of vergroten van natuurgebieden & 79 & 17 & 3 & 1 \\
\hline Meer natuur in de stad (bijv. parken en plantsoenen) & 78 & 17 & 2 & 1 \\
\hline Natuurgebieden met elkaar verbinden & 68 & 26 & 4 & 2 \\
\hline \multicolumn{5}{|l|}{ Meer natuur op het platteland (bijv. agrarische } \\
\hline natuur) & 63 & 30 & 4 & 2 \\
\hline Meer paden, bankjes, informatiepanelen e.d. & 53 & 36 & 11 & 1 \\
\hline
\end{tabular}

Vrouwen vinden alle vijf de maatregelen in de top 5 (zie tabel 5.2) belangrijker dan mannen. Ouderen hechten meer dan jongeren aan drie van de vijf maatregelen: 'Beschermen bestaande...', 'Beheren...' en 'Beschermen ... platteland'. Hoogopgeleiden hechten meer aan 'Beschermen bestaande...', terwijl jongeren meer dan ouderen 'Beschermen platteland....' belangrijk vinden. De midden opgeleiden zien meer dan de andere opleidingsniveaus in 'Beschermen zeldzame...'. Allochtonen vinden meer dan autochtonen de maatregelen 'Beheren...' en 'Bedrijven betrekken...' belangrijk. Stedelingen vinden vier van de vijf maatregelen in de top 5 belangrijker dan niet-stedelingen; enkel voor beschermen van natuur op het platteland is er geen verschil.

Bij het aangeven van de drie belangrijkste maatregelen voor natuur vindt $74 \%$ het beschermen van bestaande natuurgebieden het belangrijkst, gevolgd door het beschermen van zeldzame planten en dieren $(47 \%)$ en het beheren en onderhouden van natuurgebieden (39\%). Maatregelen als meer paden en bankjes en meer natuur op het platteland vindt men het minst van belang, zie figuur 5.6. 


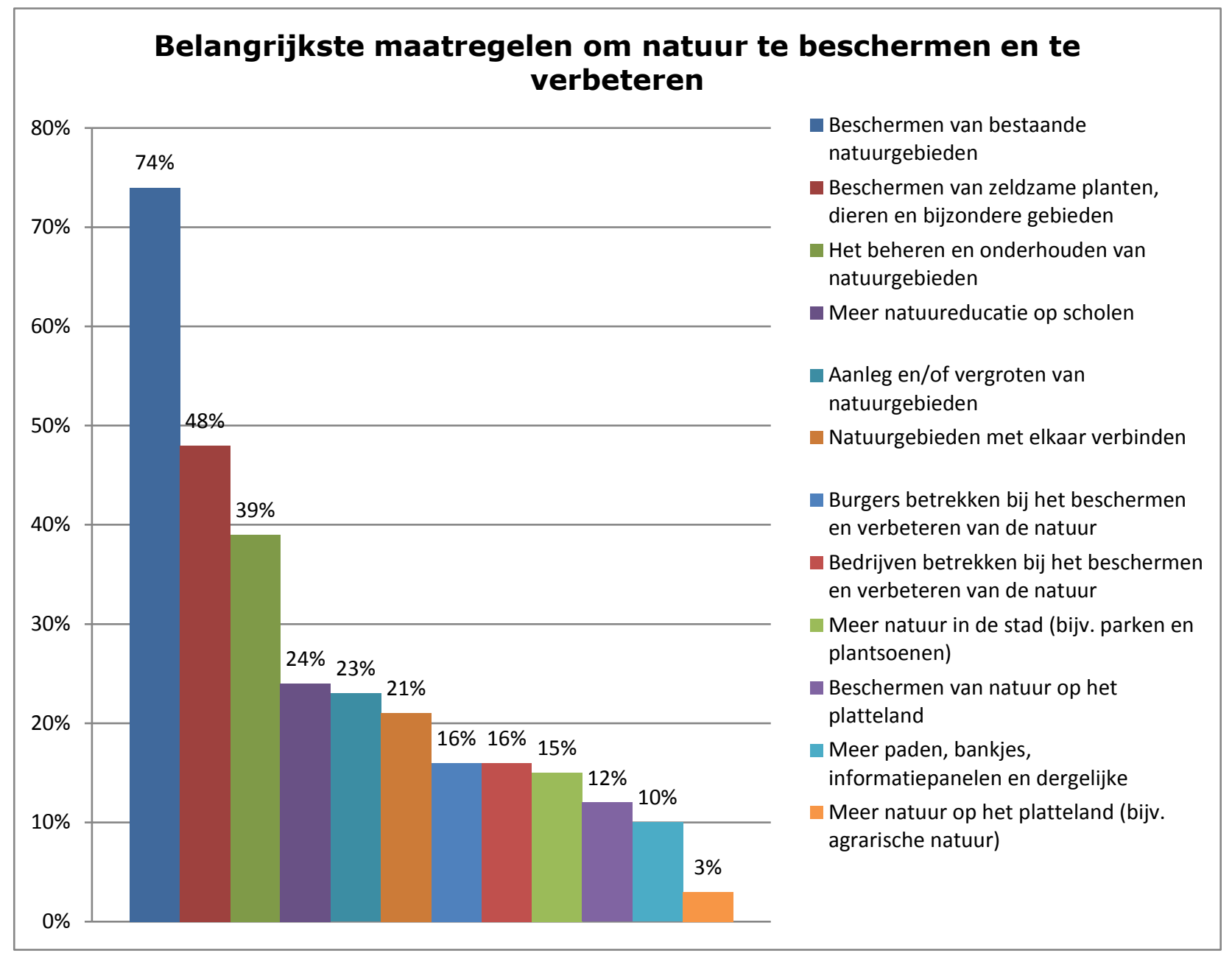

Figuur 5.6 De belangrijkste maatregelen om natuur te beheren en te verbeteren (\%).

\section{Mening over onteigening als maatregel om natuur te realiseren}

Aan de bevolking is gevraagd hoe men denkt over onteigening als maatregel om natuur te realiseren. De mening van de burgers hierover is verdeeld: $37 \%$ is het er niet mee eens, noch mee oneens, $32 \%$ is het er (helemaal) niet mee eens, $23 \%$ is het (helemaal) mee eens met de onteigeningsmaatregel en $8 \%$ weet het niet, zie figuur 5.7 .

\subsubsection{Provincies}

In de provincie Limburg en Noord-Holland vindt 78\% van de bevolking het beschermen van bestaande natuurgebieden de belangrijkste maatregel; in Zeeland is dit $69 \%$. Het beschermen van zeldzame planten en dieren vindt men het belangrijkst in Limburg en Drenthe (53\%), zie figuur 5.8. 


\section{Belangrijkste maatregelen om natuur te beschermen en te verbeteren}

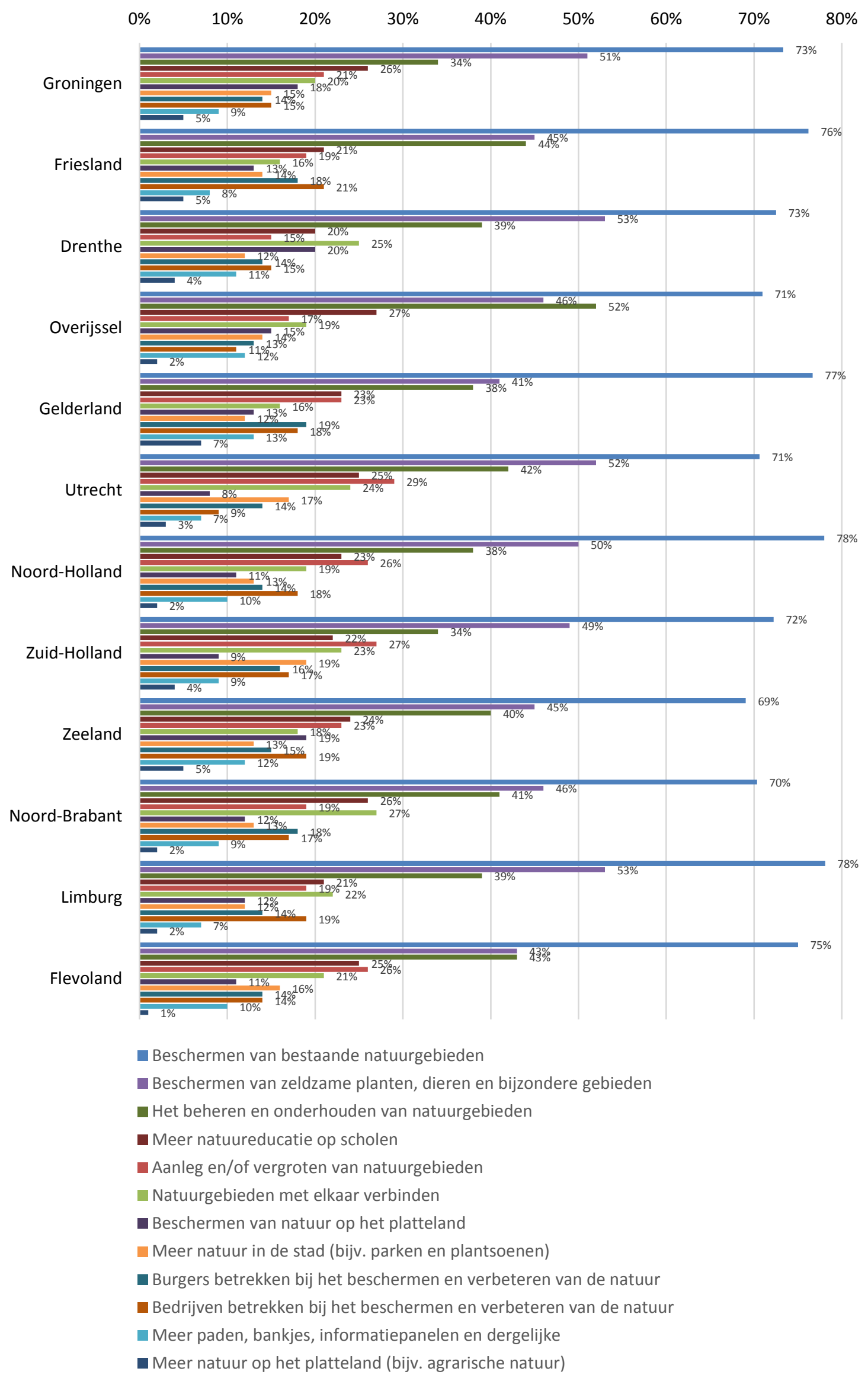

Figuur 5.7 Belangrijkste maatregelen om natuur te beschermen en te verbeteren per provincie. 


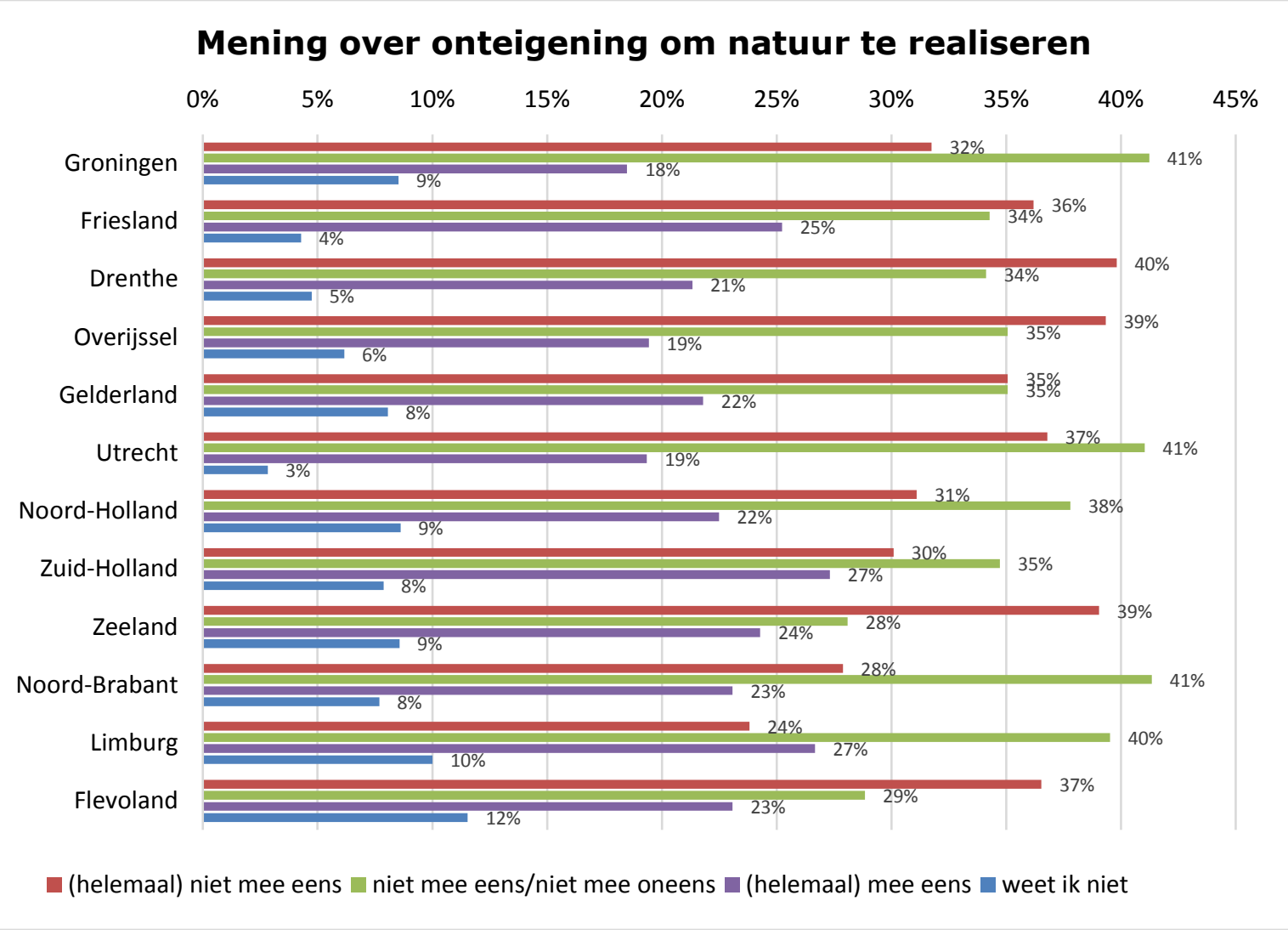

Figuur 5.8 Mening over onteigening om natuur te realiseren per provincie.

\subsubsection{Vergelijking met eerdere jaren}

De vraag over natuurbeschermingsmaatregelen is in alle draagvlakenquêtes opgenomen geweest, maar steeds in iets andere vorm. Ten opzichte van 2013 is in 2017 één maatregel-formulering aangepast en zijn vier nieuwe maatregelen opgenomen. De aanpassing betreft de maatregel aanleg en/of vergroten van natuurgebieden, deze heette voorheen aanleg nieuwe natuurgebieden. De maatregelen: (1) het beheren en onderhouden van natuurgebieden, (2) beschermen van natuur op het platteland, (3) burgers betrekken bij het beschermen en verbeteren van natuur en (4) Bedrijven betrekken bij het beschermen en verbeteren van de natuur zijn nieuw in 2017. In 2013 is de vraagformulering iets aangepast ten opzichte van 2006, maar de kern (Kunt u per maatregel aangeven in hoeverre u dit belangrijk vindt) is gelijk gebleven. In 2001 en 1996 is alleen gevraagd in hoeverre men het beschermen van bestaande natuur en de aanleg van nieuwe natuurgebieden belangrijk vindt. De acht maatregelen die ook in eerdere jaren zijn bevraagd zijn vergeleken.

In figuur 5.9 is het percentage Nederlanders weergegeven dat de maatregel als belangrijk of zeer belangrijk heeft beoordeeld. Het beschermen van bestaande natuurgebieden vinden burgers door de jaren heen onverminderd de belangrijkste maatregel. Ook het draagvlak voor de bescherming van biodiversiteit is fors: ten opzichte van 2013 is dit gestegen van $86 \%$ naar $92 \%$ in 2017 . Opvallend is verder de stijging in het belang van de aanleg en het vergroten van natuurgebieden tussen 2013 en 2017: van 66\% naar $80 \%$ in 2017 ; daarmee is het draagvlak weer op het niveau van de periode 1996-2006. Ook het gegroeide draagvlak om natuurgebieden met elkaar te verbinden is opvallend: van $56 \%$ in 2006 naar $64 \%$ in 2013 en $70 \%$ in 2017.

Voor zeven van de acht maatregelen doen zich verschuivingen voor tussen 2006 en 2017 . Enkel het aandeel van de bevolking dat de maatregel over het beschermen van bestaande natuurgebieden (zeer) belangrijk vindt, is constant gebleven. Vergelijken we 2017 met enkel 2013, dan is enkel het belang van de maatregel van Meer paden niet veranderd (zie bijlage 4). 


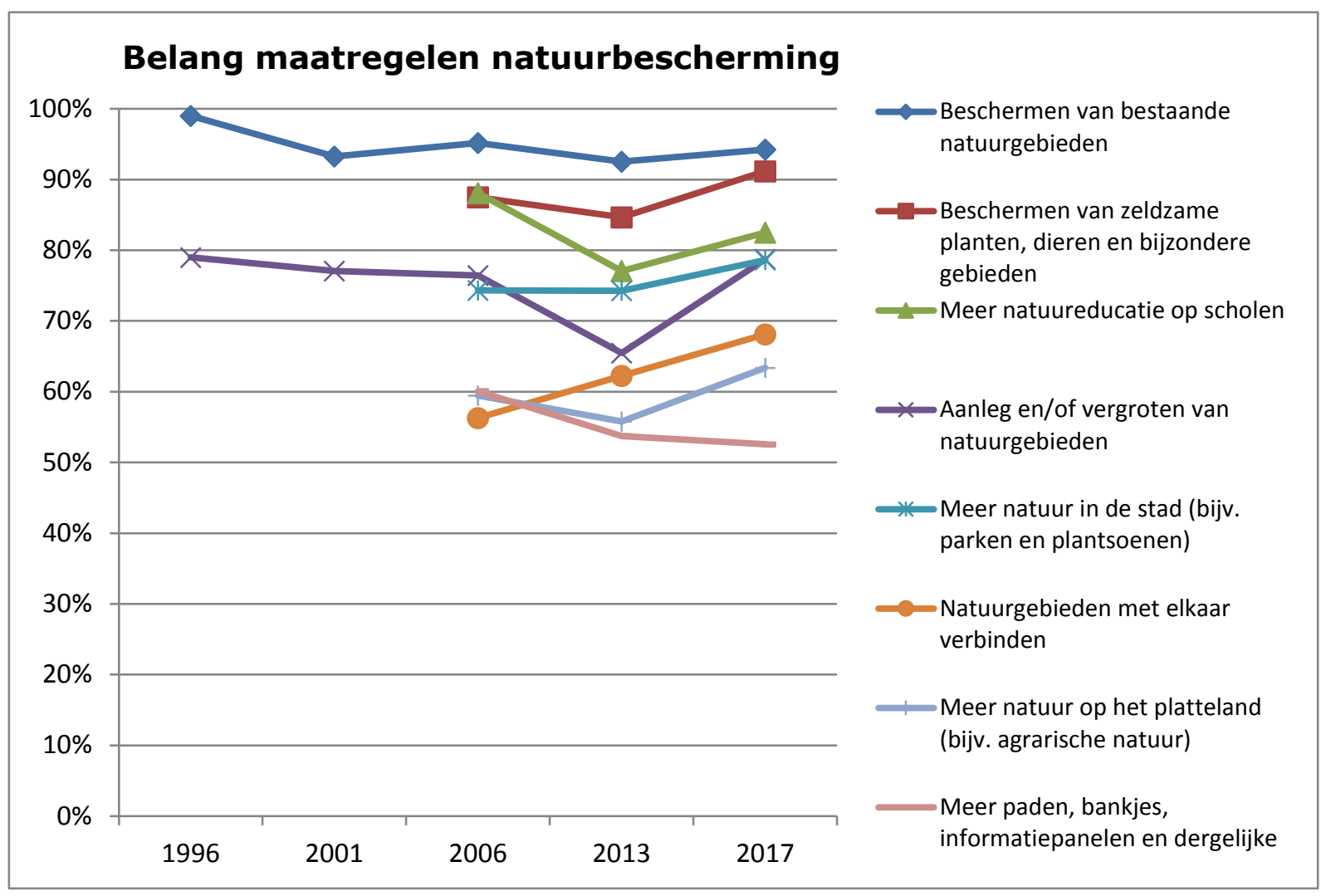

Figuur 5.9 Percentage Nederlanders dat maatregelen voor natuurbescherming (zeer) belangrijk vindt in 1996, 2001, 2006, 2013 en 2017. 



\section{$6 \quad$ Betrokkenheid bij natuur}

\section{$6.1 \quad$ Inleiding}

Tot nu hebben we draagvlak beschouwd vanuit de opvattingen (meningen, houdingen, visies) die mensen hebben voor de natuur en het natuurbeleid. Draagvlak omvat echter ook het gedrag van mensen in en rondom de natuur. In paragraaf 6.2 kijken we eerst naar het potentiële gedrag: welke mogelijkheden spreken burgers aan om betrokken te zijn bij de natuur en wat zijn hun motieven om al dan niet betrokken te willen zijn.

In de paragrafen daarna bespreken we de daadwerkelijke betrokkenheid van mensen. Burgers kunnen op verschillende manieren betrokken zijn bij de natuur: als gebruiker, als beschermer en als medebeslisser. In paragraaf 6.3 bespreken we de rol van burgers als gebruiker aan de hand van natuurbezoek en gebruik van informatiebronnen. In paragraaf 6.4 komt de rol van burgers als beschermer aan de orde, waarbij we kijken naar activiteiten die men verricht voor natuur en landschap, lidmaatschap natuurorganisaties en financiële bijdragen aan natuur. In paragraaf 6.5 gaat het over de rol van burgers als medebeslisser. Indicatoren voor deze rol zijn activiteiten die mensen ondernemen om besluitvorming over natuur te beïnvloeden en betrokkenheid bij burgerinitiatieven. Tot slot maken we in paragraaf 6.6 een segmentatie van burgerbetrokkenheid bij natuur.

\subsection{Potentiële betrokkenheid bij de natuur}

\subsubsection{Landelijk beeld}

Een ruime meerderheid van de bevolking ( $82 \%$ ) spreekt het aan om betrokken te zijn bij de natuur. Het meedenken met overheden of natuurorganisaties (47\%) en informatie ontvangen over wat men kan doen (46\%) spreekt het meest aan, maar ook zelf met medebewoners buurtgroen of natuur onderhouden ziet $36 \%$ wel zitten. Vrijwilligerswerk is voor $26 \%$ een optie (tabel 6.1 ).

Tabel 6.1 Mogelijkheden die burgers aanspreken om betrokken te zijn bij de natuur (\%).

\begin{tabular}{ll} 
Mogelijkheden* & $\%$ \\
\hline $\begin{array}{l}\text { Meedenken met de gemeente, provincie of natuurorganisatie(s) over hun } \\
\text { plannen voor natuur }\end{array}$ & 47 \\
\hline Geïnformeerd worden over wat ik kan doen voor de natuur & 46 \\
\hline Zelf met medebewoners buurtgroen of natuur verbeteren of onderhouden & 36 \\
\hline Vrijwilligerswerk doen voor een lokale, provinciale of landelijke & 26 \\
\hline natuurorganisatie & \\
\hline Ik wil niet betrokken zijn & 18 \\
\hline Meerdere antwoorden mogelijk &
\end{tabular}

Meer mannen dan vrouwen willen meedenken, vrouwen willen daarentegen meer dan mannen geïnformeerd worden en ook zelf meedoen met het beheer van buurtgroen. Ouderen willen meer dan jongeren meedenken, jongeren willen meer dan ouderen geïnformeerd worden. Hoogopgeleiden staan meer dan laagopgeleiden open voor meedenken, geïnformeerd worden en zelf buurtgroen onderhouden. Autochtonen willen vaker dan allochtonen meedenken en stedelingen willen meer dan niet-stedelingen geïnformeerd worden.

De belangrijkste motieven om betrokken te willen zijn bij de natuur zijn betrokkenheid bij de woonomgeving (48\%), actief en gezond blijven (44\%) en iets voor de maatschappij doen (37\%), zie tabel 6.2. 
Tabel 6.2 Motieven om betrokken te willen zijn bij de natuur (\%, N=2082.

\begin{tabular}{ll} 
Motieven* & $\%$ \\
Betrokkenheid bij mijn woonomgeving & 48 \\
\hline Actief en gezond blijven & 44 \\
\hline Iets voor de maatschappij doen & 37 \\
\hline Zinvolle tijdsbesteding & 24 \\
\hline Nieuwe kennis en vaardigheden opdoen & 18 \\
\hline Leuk, interessant werk & 17 \\
\hline Andere mensen ontmoeten, vrienden maken & 10 \\
\hline Verbreden van levenservaring & 9 \\
\hline Morele, religieuze en/of politieke principes & 8 \\
\hline Nuttige contacten opdoen & 5 \\
\hline Het geeft sociale erkenning & 4 \\
\hline Anders & 3 \\
\hline
\end{tabular}

* Meerdere antwoorden mogelijk

Voor vrouwen is betrokkenheid een belangrijker motief dan voor mannen, ouderen hebben vaker dan jongeren betrokkenheid en ook actief blijven als motief, jongeren kiezen vaker dan ouderen voor iets voor de maatschappelijk doen. Hoogopgeleiden noemen vaker dan laagopgeleiden het motief iets voor de maatschappij doen. Autochtonen kiezen vaker dan allochtonen voor de motieven betrokkenheid en iets voor de maatschappij doen.

Uit tabel 6.3 blijkt dat een vijfde van de bevolking niet betrokken wil zijn bij de natuur. Als belangrijkste reden geeft men aan geen tijd hiervoor te hebben (60\%). Ook zijn mensen druk met ander vrijwilligerswerk (19\%) of onbekend met de mogelijkheden om iets te doen voor de natuur $(13 \%)$.

Tabel 6.3 Motieven om niet betrokken te willen zijn bij de natuur (\%, N=443).

\begin{tabular}{ll} 
Motieven* & $\%$ \\
Geen tijd & 60 \\
\hline Ander vrijwilligerswerk & 19 \\
\hline Onbekend met de mogelijkheden om iets te doen & 13 \\
\hline Niet belangrijk genoeg, natuur heeft geen prioriteit & 10 \\
\hline Anders & 12 \\
\hline
\end{tabular}

* Meerdere antwoorden mogelijk

Mannen noemen vaker dan vrouwen als reden geen tijd. Vrouwen noemen vaker dan mannen ander vrijwilligerswerk als reden. Jongeren noemen vaker dan ouderen geen tijd en ouderen vaker dan jongeren ander vrijwilligerswerk als reden. Hoogopgeleiden geven vaker dan lager opgeleiden geen tijd als reden en laagopgeleiden kiezen vaker dan hoogopgeleiden voor onbekend met de mogelijkheden. Allochtonen noemen vaker dan autochtonen geen tijd als reden en autochtonen geven vaker aan dat ze ander vrijwilligerswerk doen. Stedelingen noemen ook vaker geen tijd als reden. Onbekend met de mogelijkheden noemen niet-stedelingen vaker dan stedelingen.

\subsubsection{Provincies}

In Noord-Holland is het percentage mensen dat geïnformeerd zou willen worden het hoogst (53\%). De helft (of meer) van de bewoners in Flevoland, Limburg en Drenthe zou mee willen denken met gemeente, provincie of natuurorganisatie(s). Friesland kent het laagste percentage burgers dat niet betrokken wil zijn $(13 \%)$, zie figuur 6.1 .

Uit figuur 6.2 blijkt dat in de provincies Zeeland, Flevoland, Utrecht en Drenthe de helft van de inwoners betrokkenheid bij de woonomgeving noemt als belangrijkste motief om betrokken te willen zijn bij natuur. Op het motief actief en gezond blijven scoren de provincies Zuid-Holland, Limburg en Friesland het hoogst. 


\section{Mogelijkheden die burgers aanspreken om betrokken te zijn bij natuur}

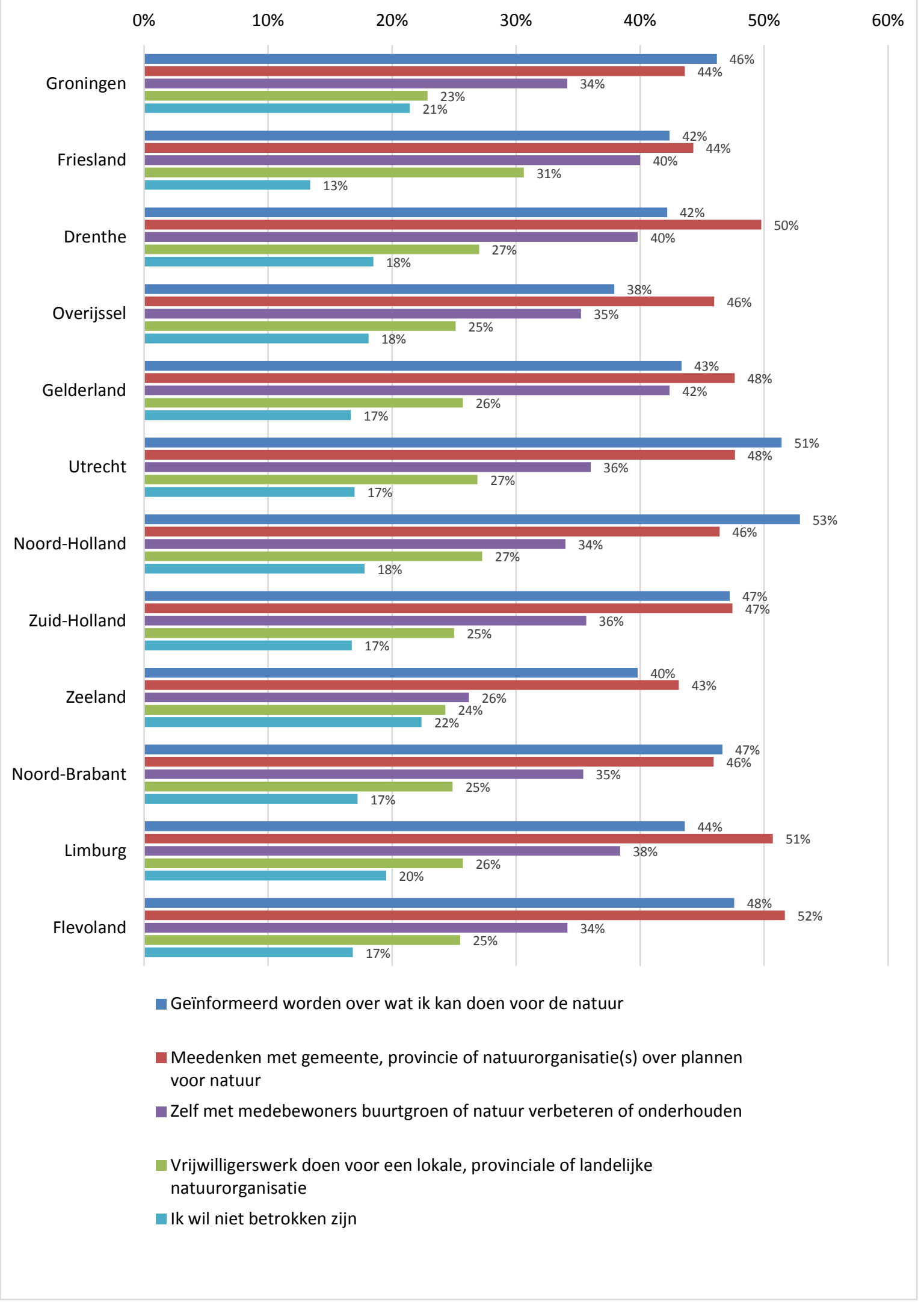

Figuur 6.1 Mogelijkheden die burgers aanspreken om betrokken te zijn bij natuur per provincie. 


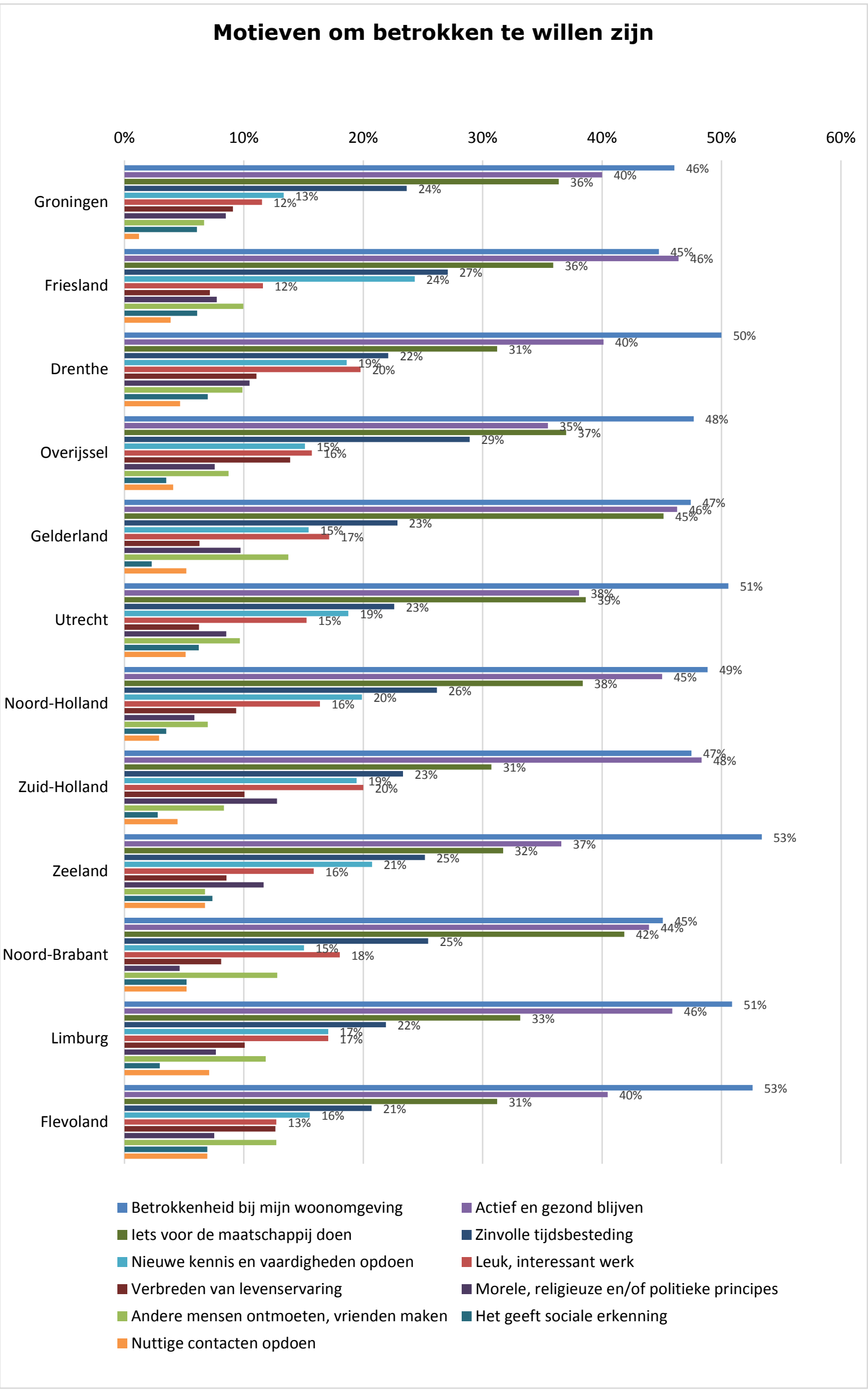

Figuur 6.2 Motieven om betrokken te willen zijn bij natuur per provincie. 
In Friesland noemt $79 \%$ geen tijd als belangrijkste reden om niet betrokken te willen zijn. In Overijssel is dit $45 \%$. In Gelderland (29\%) en Flevoland (28\%) is men het drukst met ander vrijwilligerswerk, zie figuur 6.3.

\section{Motieven om niet betrokken te willen zijn}

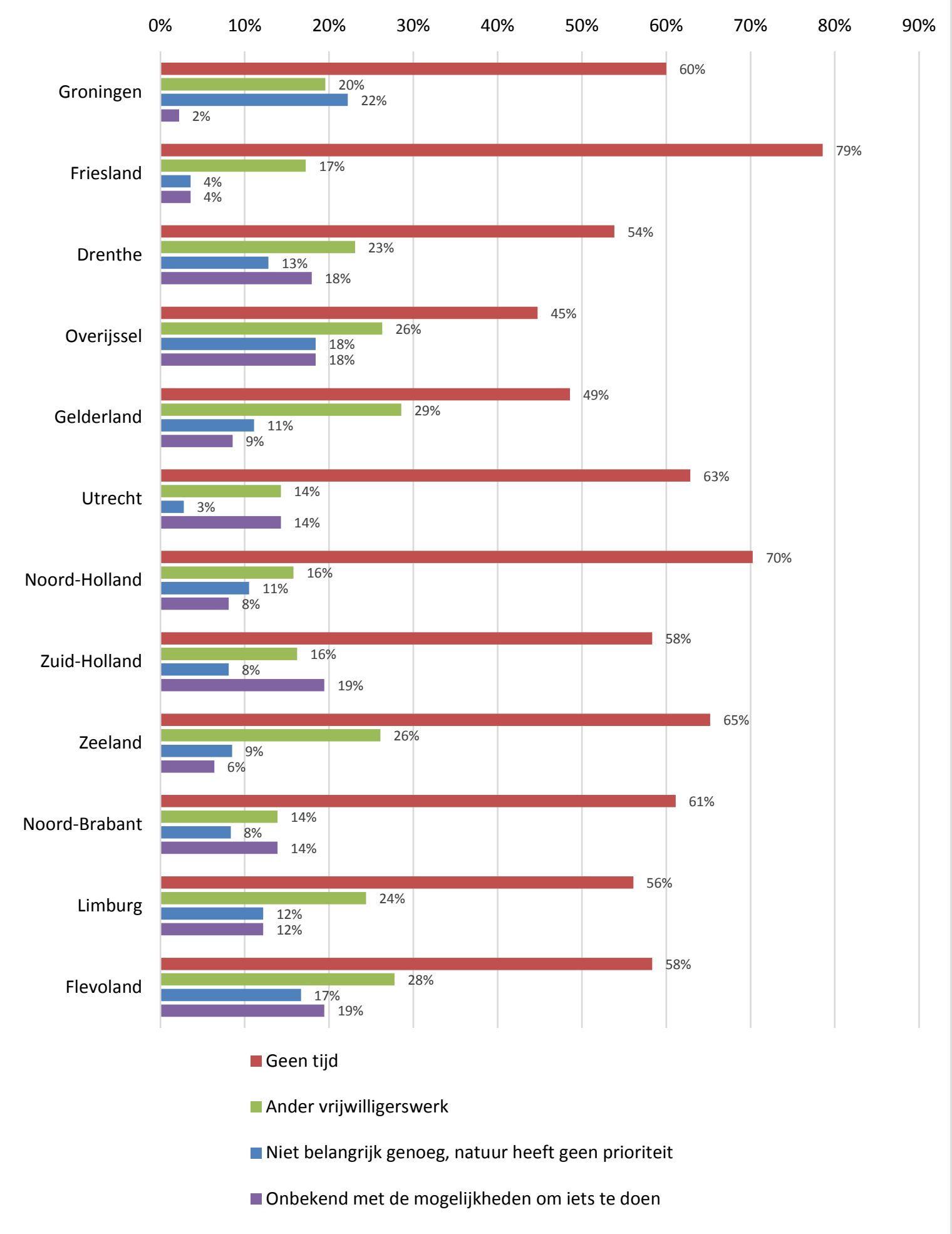

Figuur 6.3 Motieven om niet betrokken te willen zijn bij natuur per provincie. 


\subsection{Burger als gebruiker}

\subsubsection{Landelijk beeld: bezoek aan stadsgroen, platteland en natuurgebieden}

Aan de respondenten is gevraagd hoe vaak ze in het afgelopen jaar hun vrije tijd doorbrachten in parken en groen in de stad, het platteland en in natuurgebieden (bos, heide, duinen, meren, plassen). Natuurgebieden worden het meest bezocht door de bevolking: 55\% komt hier regelmatig tot vaak. Voor stadsgroen is dit percentage 47 en voor het platteland 41 (figuur 6.4).

$\mathrm{Er}$ is weinig verschil tussen inwoners van de vier grote steden en overig Nederland wat betreft het regelmatig bezoeken van parken, platteland en natuurgebieden. Er treedt wel een verschil op tussen beide groepen als het gaat om de categorie (zeer) vaak. Het percentage inwoners van de vier grote steden dat parken (zeer) vaak bezoekt is 36 tegen $21 \%$ in overig Nederland. $8 \%$ van de inwoners van de vier grote steden komt (zeer) vaak op het platteland tegen $32 \%$ uit overig Nederland. Voor het (zeer) vaak bezoeken van natuurgebieden is dit $11 \%$ voor inwoners van de vier grote steden en $24 \%$ voor overig Nederland.

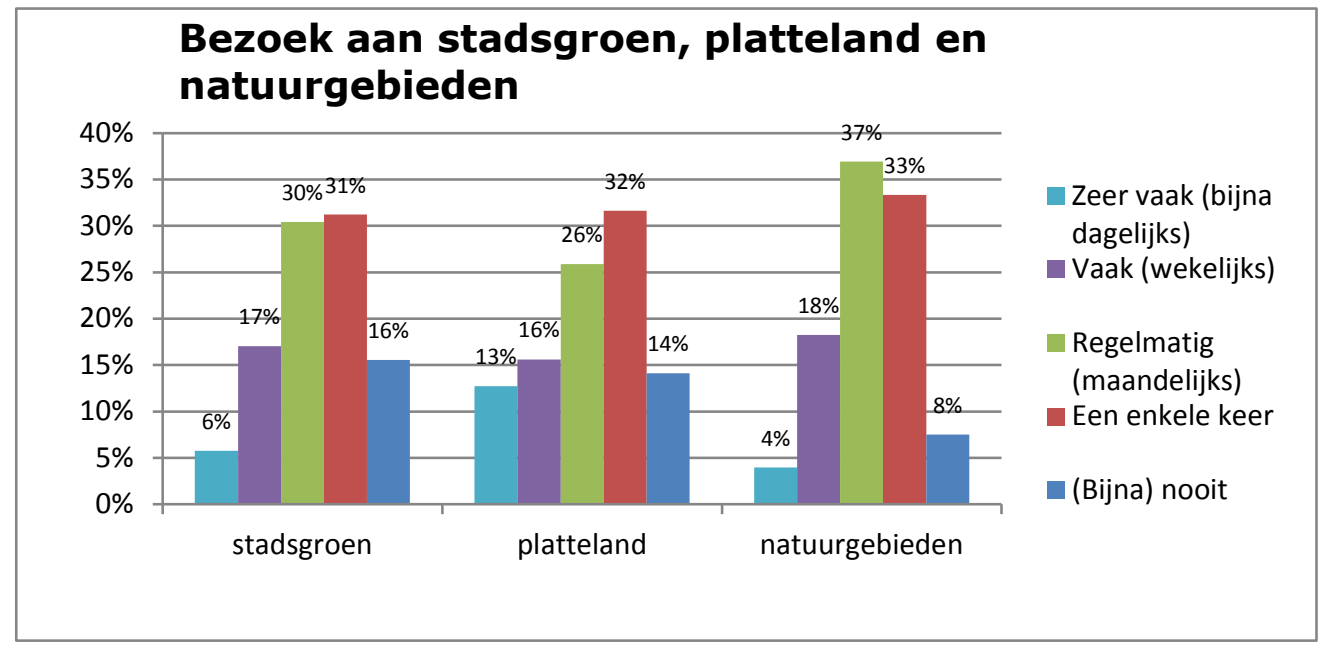

Figuur 6.4 Bezoek aan stadsgroen, platteland en natuurgebieden (\%).

Leeftijd is van invloed op het bezoek: Ouderen bezoeken parken, platteland en ook stadsgroen vaker dan andere leeftijdsgroepen. Hoogopgeleiden bezoeken stadsgroen vaker dan lager opgeleiden. Autochtonen trekken vaker dan allochtonen naar het platteland en natuurgebieden. Stedelingen bezoeken vaker dan niet-stedelingen stadsparken. Niet-stedelingen komen meer dan stedelingen op het platteland en in natuurgebieden.

\subsubsection{Provincies: bezoek aan stadsgroen, platteland en natuurgebieden}

\section{Bezoek aan stadsgroen}

Inwoners van Noord-Holland en Utrecht maken het vaakst gebruik van groen in de stad; resp. $29 \%$ en $28 \%$ komt er (zeer) vaak. Bewoners van Zeeland maken het minst gebruik van groen in de stad; $61 \%$ komt hier nooit, zie figuur 6.5.

\section{Bezoek aan natuur op het platteland}

Uit figuur 6.6 blijkt dat inwoners van Zeeland het vaakst natuur op het platteland bezoeken; $51 \%$ komt er (zeer) vaak). Inwoners van Flevoland (14\%) en Zuid-Holland 15\%) bezoeken het platteland het minst.

\section{Bezoek aan natuurgebieden}

Inwoners van Drenthe bezoeken het vaakst natuurgebieden; 35\% komt er (zeer) vaak). Inwoners van Flevoland (17\%) en Zuid-Holland (12\%) bezoeken natuurgebieden het minst, zie figuur 6.7. 


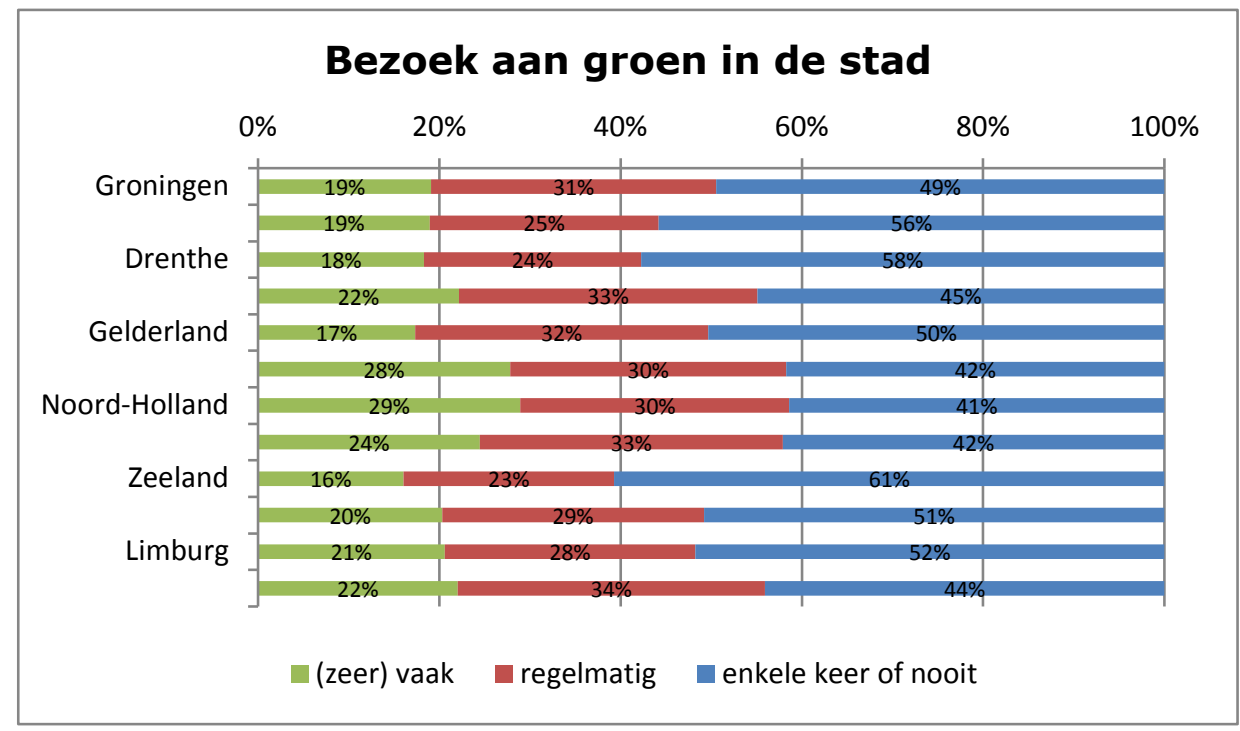

Figuur 6.5 Bezoek aan groen in de stad per provincie.

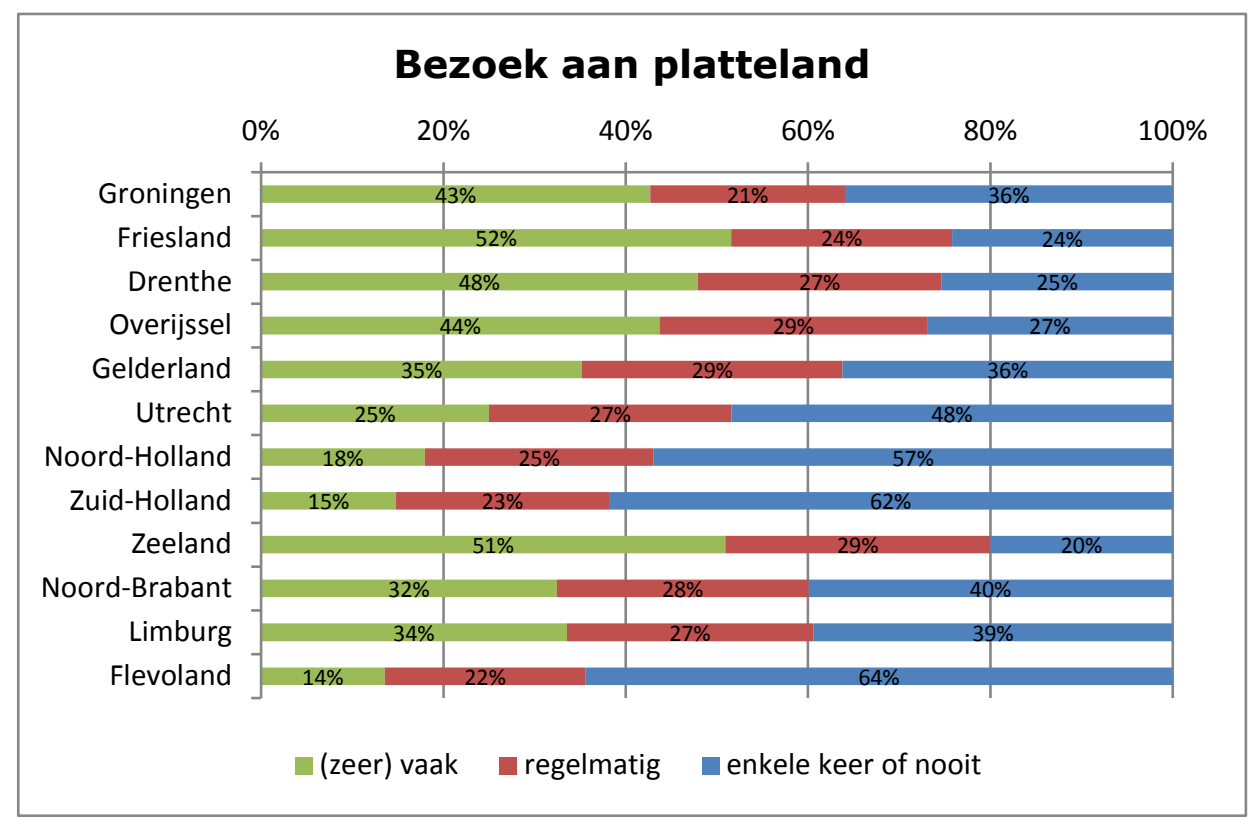

Figuur 6.6 Bezoek aan platteland per provincie.

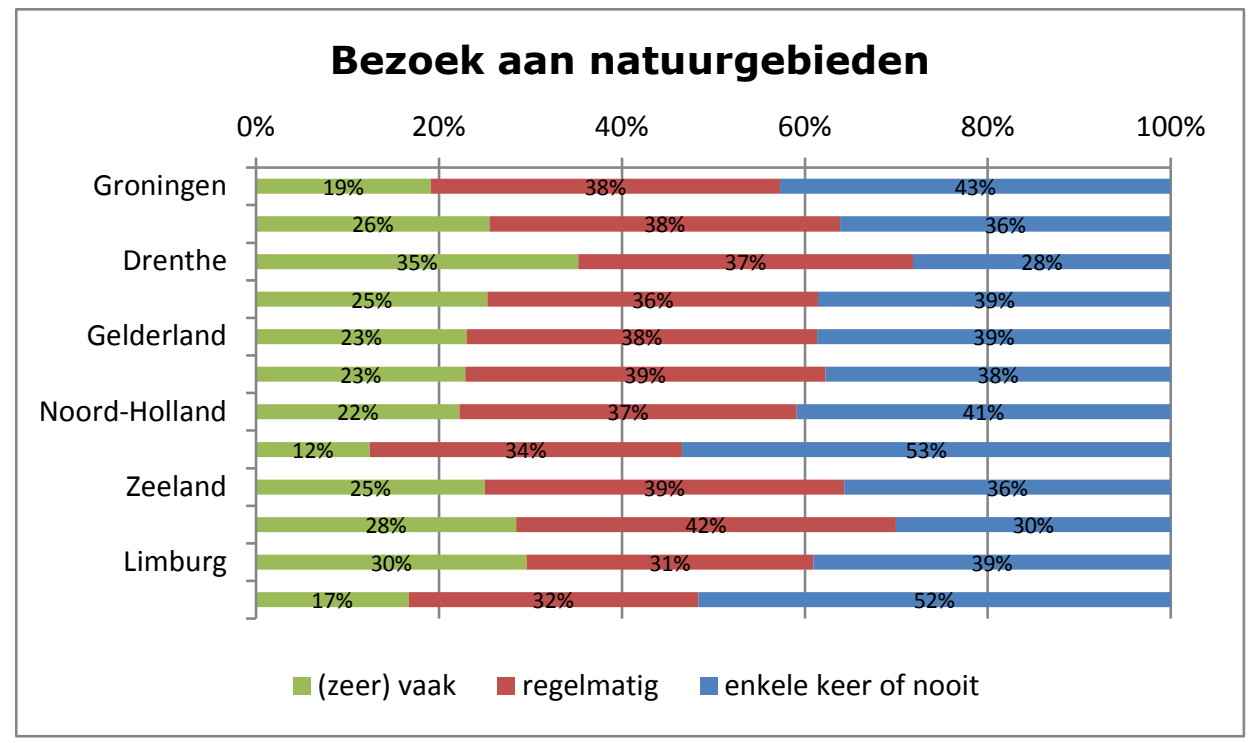

Figuur 6.7 Bezoek aan natuurgebieden per provincie. 


\subsubsection{Vergelijking met eerdere jaren}

Naar het natuurbezoek is ook in eerdere draagvlakenquêtes gevraagd. In 2017 zijn de antwoordcategorieën van de vraag enigszins aangepast ten opzichte van 2013. De volgende categorieën zijn meer gespecificeerd: Regelmatig (de toelichting maandelijks toegevoegd), Vaak (de toelichting wekelijks toegevoegd) en Zeer vaak (bijna dagelijks toegevoegd). In 2013 is ten opzichte van 2006 één antwoordcategorie iets aangepast: parken en groen in de stad in plaats van stadsparken, stadsbossen en plantsoenen. Daarnaast is in 2013 ook gevraagd naar de bezoekfrequentie van het platteland. In 2001 is geen vraag gesteld over natuurbezoek. Een vergelijking met 1996 is niet mogelijk, door een andere vraagstelling en andere antwoordcategorieën in dat jaar.

In figuur 6.8 zijn de vijf antwoordcategorieën ingedikt tot drie categorieën. Tussen 2013 en 2017 doet zich geen verschil voor in de bezoekfrequentie van het platteland. Tussen 2006, 2013 en 2017 is wel het parkbezoek toegenomen, het bezoek aan natuurgebied is toegenomen tussen 2006 en 2013, en weer ietwat gedaald tussen 2013 en 2017 (zie ook bijlage 4).

\section{Bezoek platteland, natuurgebied en parken \& groen in de stad}

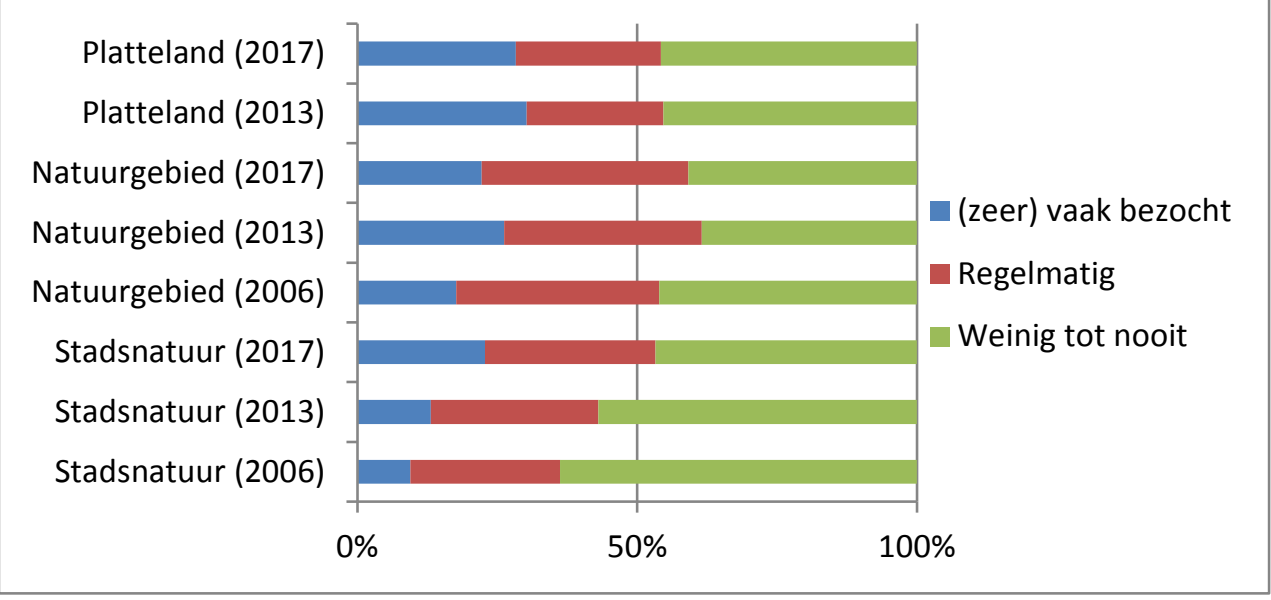

Figuur 6.8 Bezoekfrequentie Nederlanders aan platteland, natuurgebied en stadsnatuur in 2006, 2013 en 2017

\subsubsection{Landelijk beeld: gebruik van informatiebronnen over natur}

Er bestaan verschillende manieren waarop burgers zich informeren over natuur (tabel 6.4). Aan de bevolking is gevraagd van welke media zij gebruik hebben gemaakt in het afgelopen jaar. $76 \%$ van de bevolking gebruikt één of meerdere informatiebronnen ( $28 \%$ gebruikt één bron, $28 \%$ twee en $16 \%$ drie bronnen), waarvan televisiekijken veruit de meest gebruikte is (64\%). Internet wordt door een derde van de burgers geraadpleegd.

Tabel 6.4 Geraadpleegde informatiebronnen over natuur (\%)

\begin{tabular}{lc}
\hline Informatiebron* & $\%$ \\
\hline Televisieprogramma of film over natuur & 64 \\
\hline Internet over natuur geraadpleegd & 33 \\
\hline Tijdschrift/boek/artikel over natuur gelezen & 26 \\
\hline Social media (twitter, facebook) over natuur gevolgd & 13 \\
\hline Webcam(s) over natuur bekeken & 6 \\
\hline Apps over natuur gebruikt & 4 \\
\hline Anders & 4 \\
\hline Geen van deze & 24 \\
\hline
\end{tabular}

* Meerdere antwoorden mogelijk 
Mannen gebruiken vaker dan vrouwen het internet voor informatie over natuur. Ouderen kijken vaker dan jongeren naar televisieprogramma's over natuur, en ook lezen ze meer tijdschriften.

Laagopgeleiden kijken vaker naar televisieprogramma's, hoogopgeleiden halen hun informatie vaker dan lager opgeleiden uit tijdschriften en het internet. Autochtonen raadplegen vaker tijdschriften en het internet als bron dan autochtonen. Niet-stedelingen lezen vaker dan stedelingen een tijdschrift over natuur.

\subsubsection{Provincies: gebruik van informatiebronnen over natuur}

Het percentage burgers dat de tv als informatiebron gebruikt varieert van $72 \%$ in Friesland tot $58 \%$ in Zeeland. De provincie Flevoland heeft het hoogste percentage burgers (29) dat geen gebruik maakt van informatiebronnen over natuur, zie figuur 6.9.

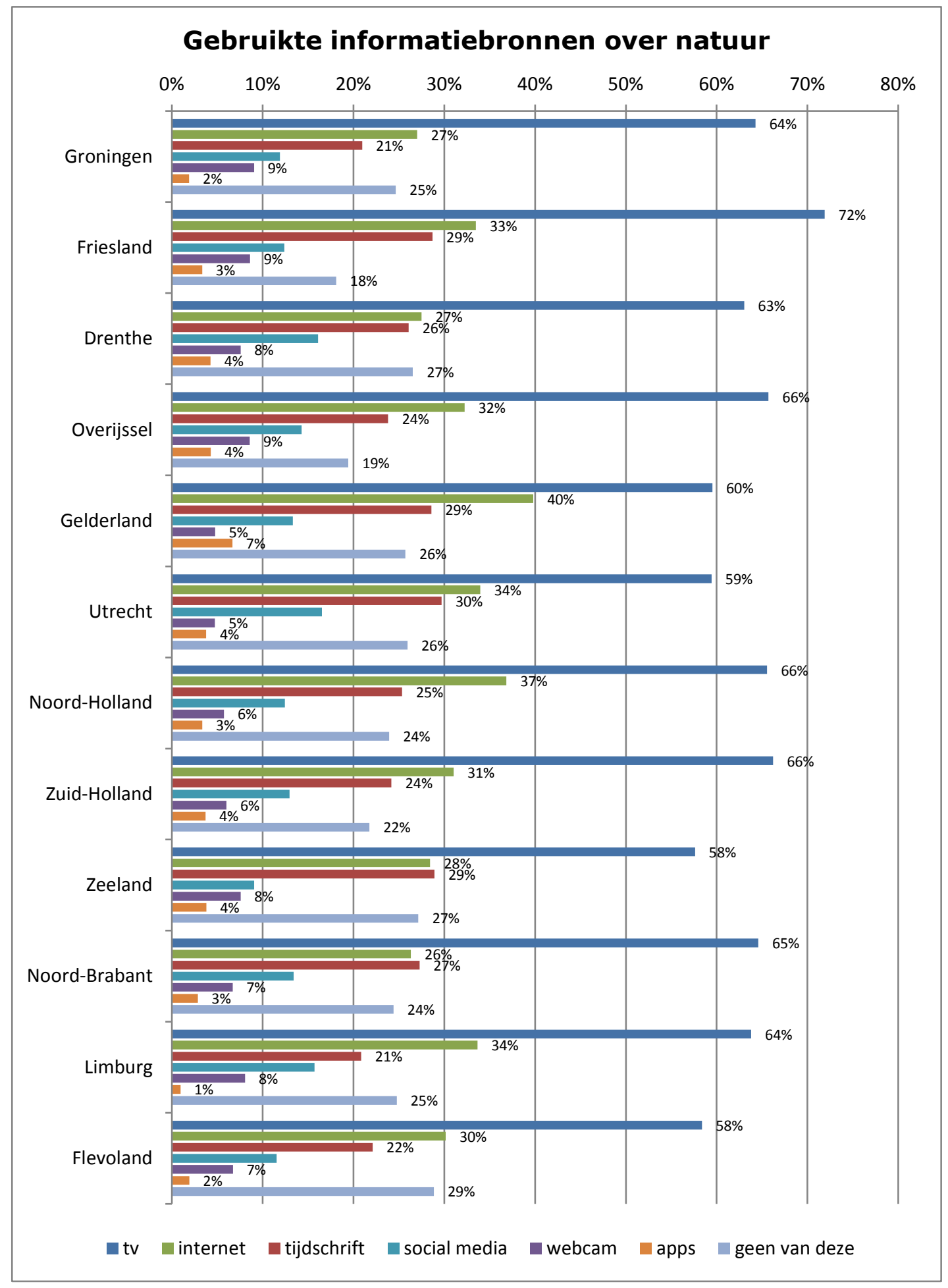

Figuur 6.9 Gebruikte informatiebronnen per provincie. 


\subsubsection{Vergelijking met eerdere jaren}

De vraag over informatiebronnen is in 2006 en 2013 ook gesteld, het aantal en type bevraagde bronnen is met de jaren veranderd. De vraag naar het gebruik van apps is nieuw in 2017 en doet dus niet mee in de tijdanalyse. In 2013 zijn twee categorieën toegevoegd ten opzichte van 2006: webcam(s) over natuur bekeken en social media gevolgd. Daarnaast is ook een aantal categorieën weggelaten. In 2001 en 1996 is deze vraag niet gesteld. De vijf bronnen die eerder zijn voorgelegd doen mee in de analyse.

Figuur 6.10 laat zien dat tussen 2006 en 2017 het internet vaker is geraadpleegd, met een piek in 2013. Tussen 2013 en 2017 zijn minder televisieprogramma 's over natuur bekeken, en ook zijn in de periode 2006-2017 minder tijdschriften gelezen en is het gebruik van webcams afgenomen. Daarentegen is het gebruik van sociale media over natuur toegenomen (zie ook bijlage 4).

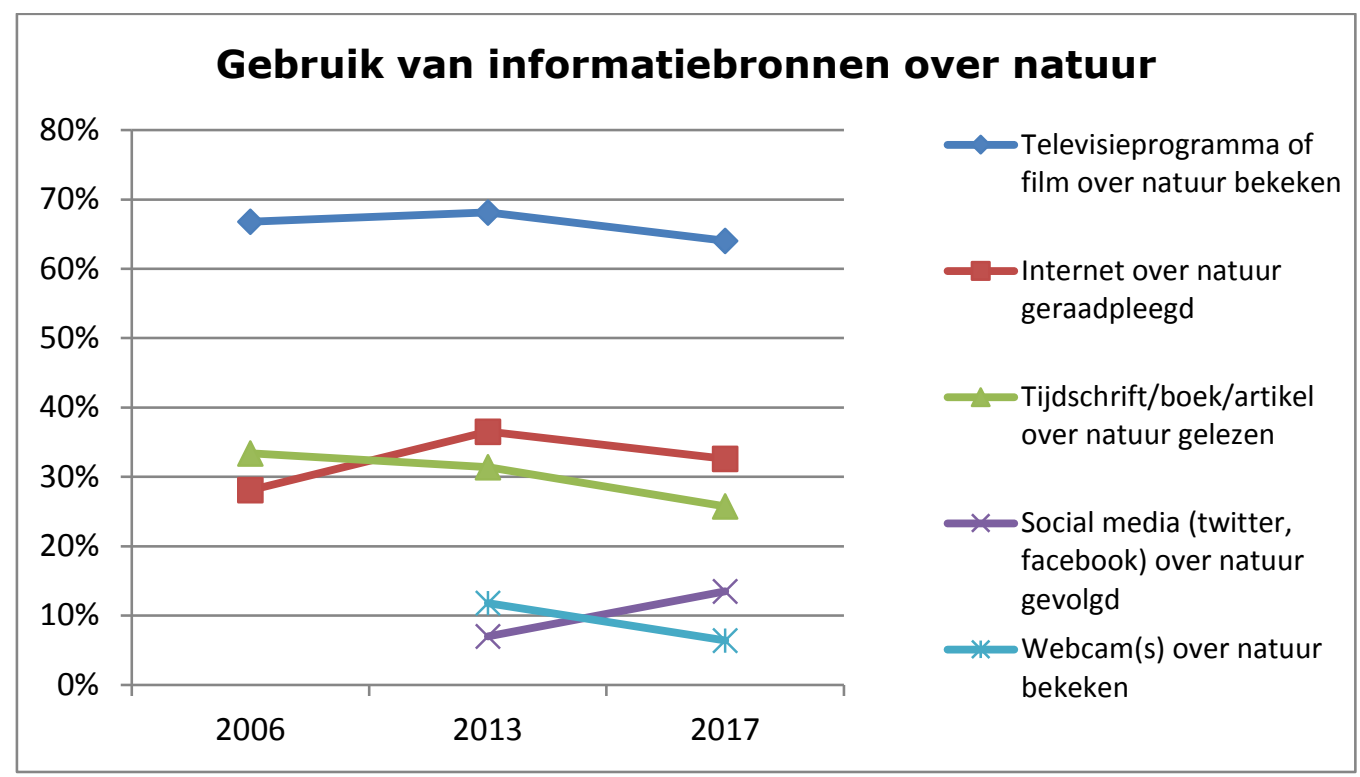

Figuur 6.10 Percentage Nederlanders dat de informatiebron over natuur raadpleegde in 2006, 2013 en 2017.

\subsection{Burger als beschermer}

\subsubsection{Landelijk beeld: ondernomen activiteiten voor natuur en landschap}

Aan de bevolking is gevraagd welke activiteiten ze hebben ondernomen voor natuur- en landschapsbeheer. 57\% van de burgers verricht één of meer activiteiten (31\% verricht één activiteit, 16\% twee). Het plaatsen van nestkastjes/voederplankjes (31\%), afval van anderen in de natuur opruimen (28\%) en streekeigen beplanting aanleggen (11\%) zijn de activiteiten die het meest ondernomen worden (zie tabel 6.5).

Tabel 6.5 Activiteiten voor natuur en landschap die men in de afgelopen 12 maanden heeft ondernomen (\%).

\begin{tabular}{lr} 
Activiteit* & $\%$ \\
Plaatsen van nestkastjes, voederplankjes bij mijn huis & 31 \\
\hline Afval van anderen in de natuur opruimen & 28 \\
\hline Aanleg van streekeigen beplanting bij mijn huis & 11 \\
\hline Onderhoud van natuur of landschap (bomen snoeien/knotten, bermbeheer, poelen schonen) & 7 \\
\hline Sociale activiteiten in de natuur organiseren (scouting, zorg, reizen etc.) & 5 \\
\hline Weidevogelbescherming & 2 \\
\hline Inventarisatie van dier- of plantsoorten, natuurstudie & 7 \\
\hline Anders, namelijk... & 2 \\
\hline Geven van natuureducatie, lezingen en rondleidingen & 2 \\
\hline Geen van deze & 43 \\
\hline
\end{tabular}

* Meerdere antwoorden mogelijk 
Vrouwen kiezen vaker dan mannen voor het plaatsen van nestkastjes en het opruimen van afval. Ouderen hebben vaker dan jongeren nestkastjes geplaatst, afval geruimd en streekeigen beplanting aangelegd. Laagopgeleiden kiezen vaker dan hoger opgeleiden voor het plaatsen van nestkastjes. Etniciteit doet er voor alle activiteiten uit de top-5 toe: autochtonen hebben vaker nestkastjes geplaatst, afval geruimd, streekeigen beplanting aangelegd, onderhoud en weidevogelbescherming gedaan. Niet-stedelingen plaatsen vaker dan stedelingen nestkastjes en leggen vaker streekeigen beplanting aan.

\subsubsection{Provincies: ondernomen activiteiten voor natuur en landschap}

In Friesland, Drenthe en Overijssel heeft twee derde van de inwoners activiteiten ondernomen voor natuur en landschap. In Flevoland is dit $48 \%$. De meeste genoemde activiteit (nestkastjes ophangen) vindt het meest plaats in Drenthe (42\% en het minst in Noord-Holland (26\%), zie figuur 6.11.

\section{Ondernomen activiteiten voor natuur en landschap}

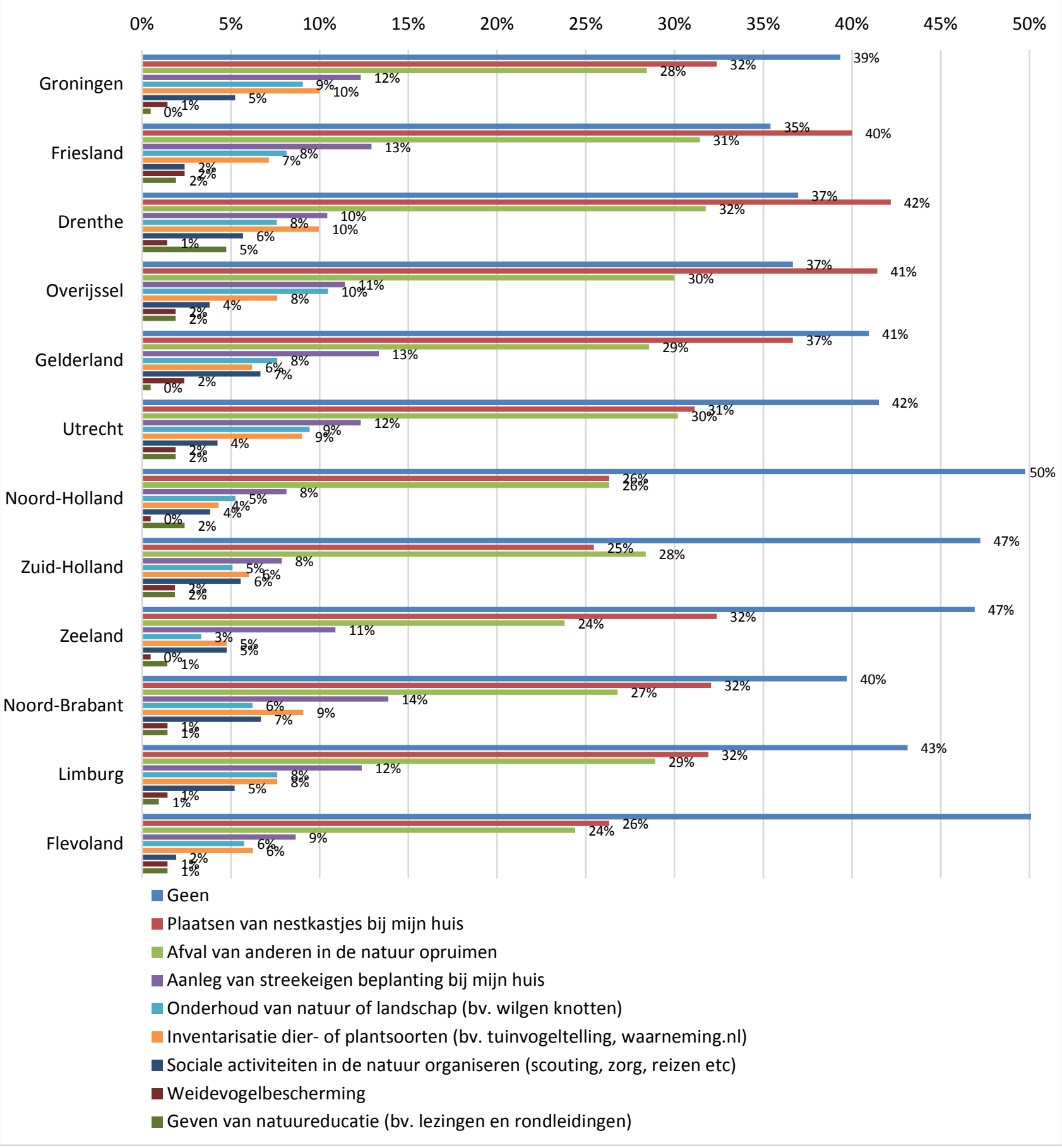

Figuur 6.11 Ondernomen activiteiten voor natuur en landschap per provincie. 


\subsubsection{Vergelijking met eerdere jaren}

De vraag over natuuractiviteiten is in 2017 ietwat aangepast ten opzichte van 2013: de zinsnede voor de natuur is toegevoegd. Daarnaast is de antwoordcategorie Inventarisatie van dier- of plantsoorten aangepast. Hieraan is toegevoegd: (bijv. tuinvogeltelling, waarneming. $\mathrm{ll}$ ). De vraagstelling was in 2006 en 2013 identiek. In 2001 en 1996 is vooral naar georganiseerd vrijwilligerswerk gevraagd. De Bakker et al. (2007) concluderen daarom dat het moeilijk is deze gegevens te vergelijken met de gegevens uit latere jaren.

Uit figuur 6.12 blijkt dat in zowel 2006, 2013 als 2017 iets meer dan de helft van de Nederlanders activiteiten voor natuur heeft verricht. Tussen 2006 en 2013 was sprake van een toename, sinds 2013 is het aantal mensen dat activiteiten heeft verricht stabiel. Kijken we naar de periode van 2006 tot 2017, dan is voor drie activiteiten de deelname verschoven: meer mensen zijn afval van anderen gaan opruimen (van $18 \%$ naar $28 \%$ ) en ook meer mensen zijn actief geworden in de inventarisatie van dier- en plantensoorten (van 1\% naar 7\%), minder mensen hebben zich beziggehouden met de aanleg van streekeigen beplanting (van 17\% naar 11\%). Tussen 2013 en 2017 zien we dat de inventarisatie en afvalruimen is toegenomen, en dat zijn afgenomen de deelname aan onderhoud van natuur en landschap, de aanleg van streekeigen beplanting en het plaatsen van nestkastjes.

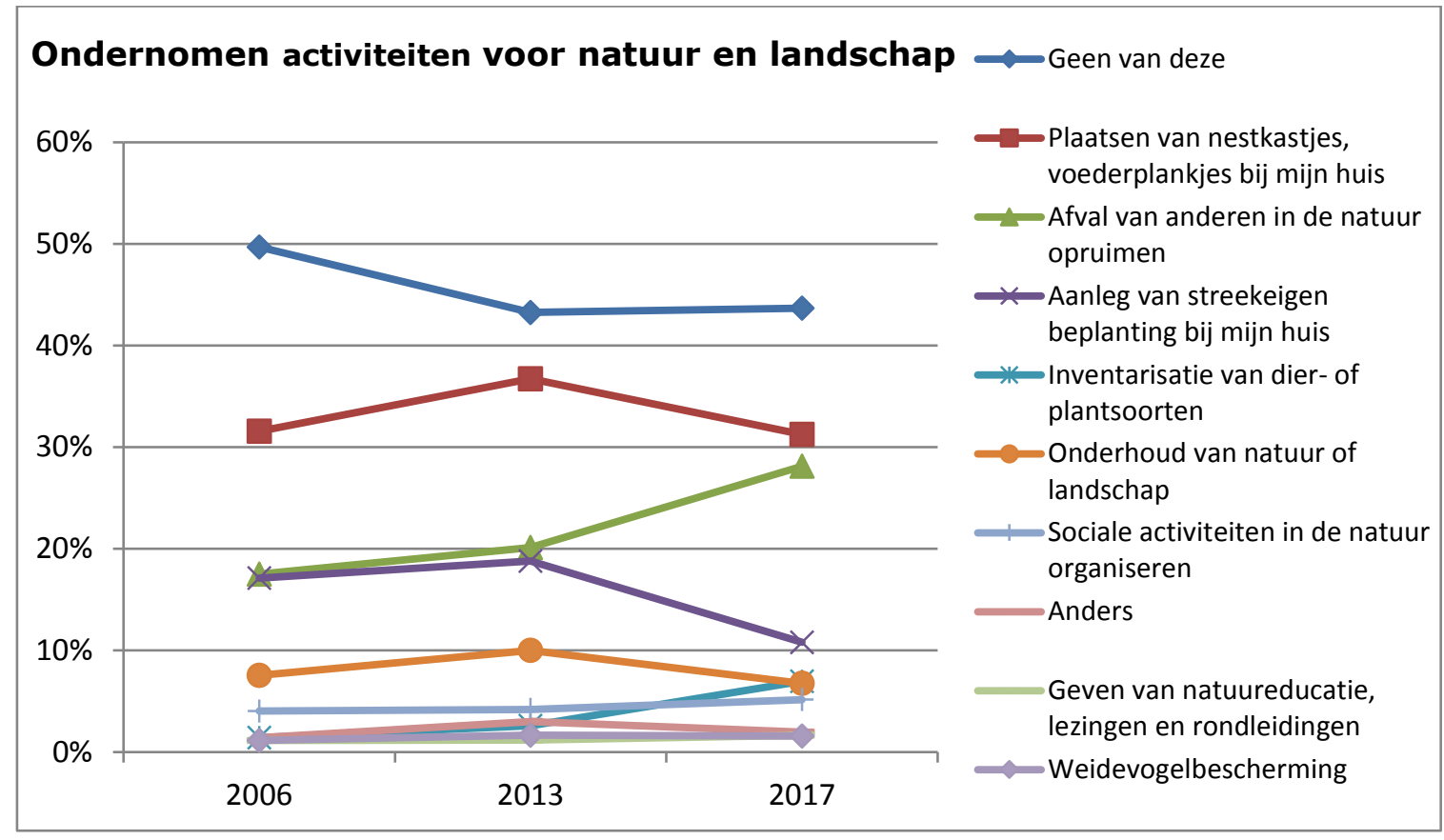

Figuur 6.12 Percentage Nederlanders dat activiteiten voor natuur en landschap ondernam in 2006, 2013 en 2017.

\subsubsection{Landelijk beeld: lidmaatschap natuurorganisaties}

Bijna een kwart van de bevolking heeft aangegeven lid te zijn van een natuurorganisatie. $12 \%$ is lid van Natuurmonumenten, $9 \%$ van het Wereldnatuurfonds, $4 \%$ van Provinciale Landschappen, $4 \%$ van Greenpeace en $4 \%$ van een andere organisatie.

Ouderen zijn vaker dan jongeren lid van een natuurorganisatie, net als hoger opgeleiden in vergelijking tot lager opgeleiden. Ook autochtonen zijn vaker dan allochtonen lid. Kortom, leden van natuurorganisaties zijn vaker ouder, hoger opgeleid en autochtoon.

\subsubsection{Provincies: lidmaatschap natuurorganisaties}

Figuur 6.13 laat zien dat in Friesland en Utrecht een derde van de inwoners lid is van een natuurorganisatie. In Limburg en Zeeland is dit resp. 14 en $17 \%$. 


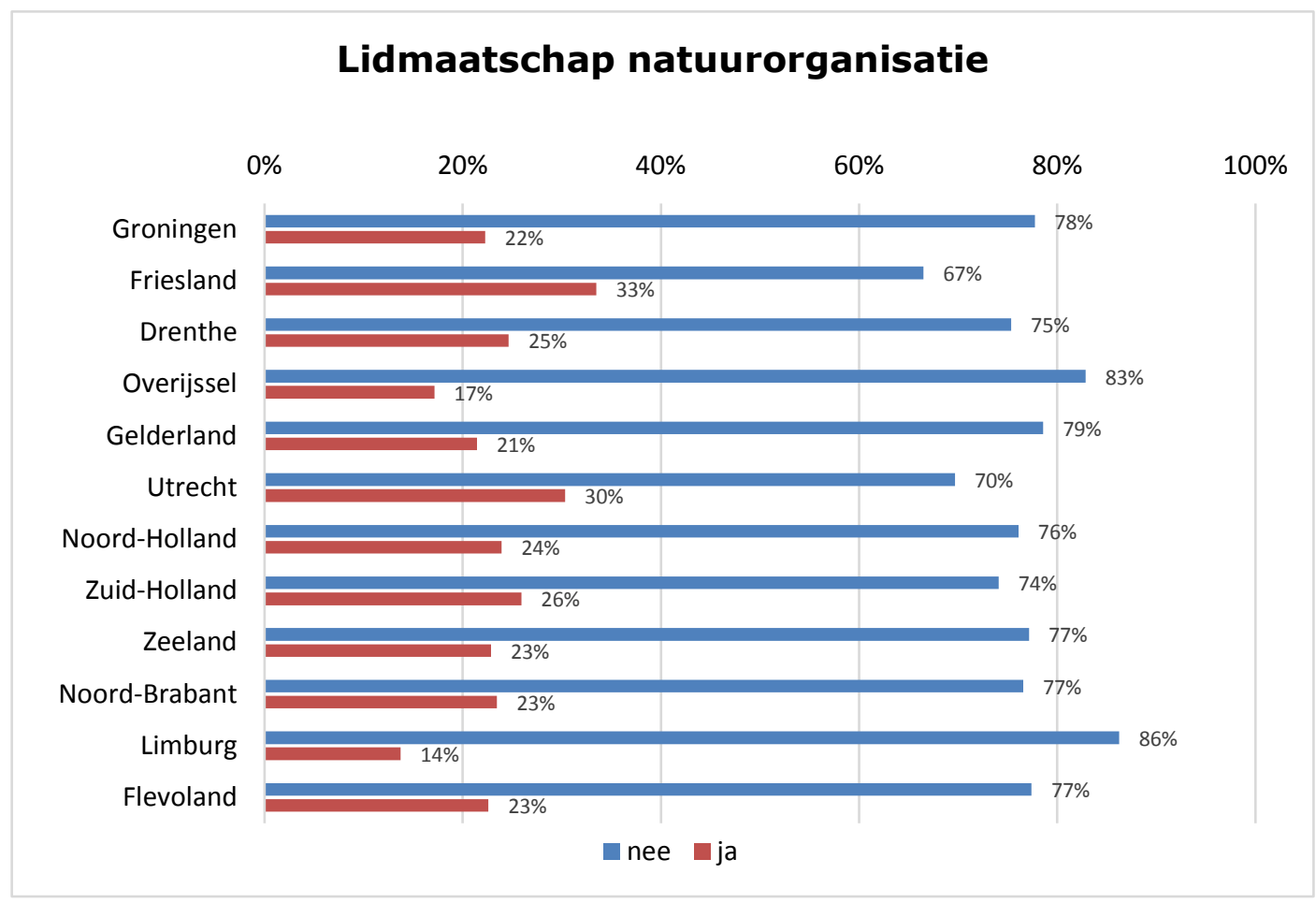

Figuur 6.13 Percentage Nederlanders dat lid is van een natuurorganisatie per provincie.

\subsubsection{Vergelijking met eerdere jaren}

In eerdere jaren is ook gevraagd naar het lidmaatschap van natuurorganisaties. De formulering verschilde per jaar. Waar in 2017 naar het lidmaatschap van vier natuurorganisaties (plus een categorie anders) is gevraagd, was de vraagstelling in 2013: "Bent u lid van een natuurorganisatie (bijv. Natuurmonumenten, Provinciaal Landschap)?" In 2006 werd in vergelijking tot 2017 gevraagd naar deels andere natuurorganisaties: Greenpeace was in 2006 geen antwoordmogelijkheid, terwijl twee andere organisaties na 2006 niet meer in de vragenlijst waren opgenomen: Vogelbescherming en Lokale natuur- of landschapsvereniging. In 2006 kwam de antwoordcategorie 'geen van deze' voor. Deze formulering is enigszins onduidelijk. We hebben deze categorie opgevat als het niet lid zijn van een natuurorganisatie, maar beter was geweest om expliciet te vragen of de respondent geen lid is, zoals in 2017 is gebeurd. In 2001 en 1996 is ook naar het lidmaatschap van milieuorganisaties gevraagd. Daardoor is het niet goed mogelijk deze gegevens met de latere studies te vergelijken.

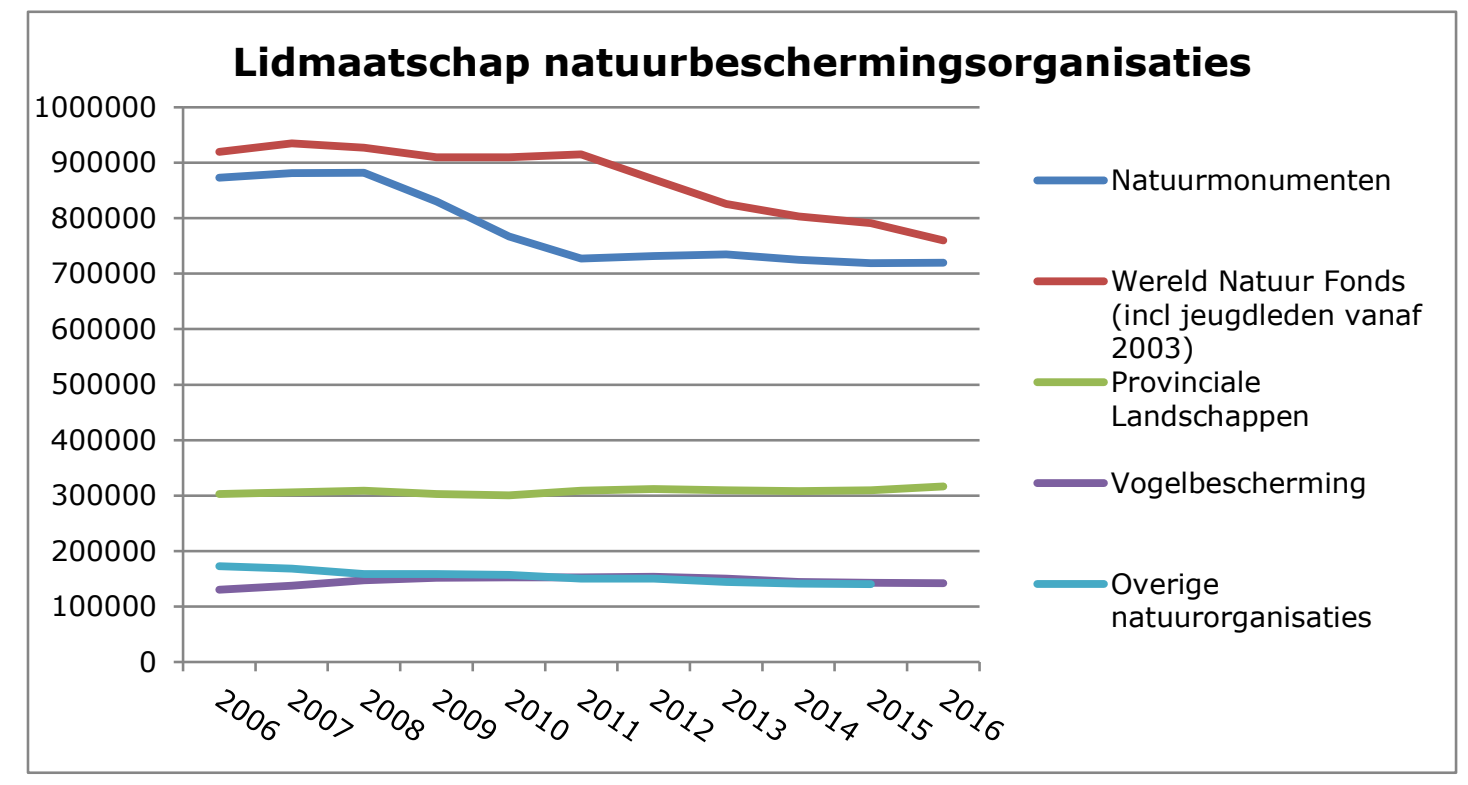

Figuur 6.14 Aantallen leden van natuurorganisaties in de periode 2006-2016 (Bron: CBS et al, 2017) 
Uit de antwoorden blijkt dat in 2006 30\% van de bevolking lid was van een natuurorganisatie, in 2013 nog slechts $19 \%$, waarna de steun voor natuurorganisaties in 2017 weer aantrok tot $24 \%$ lidmaatschap. De cijfers laten dus een forse daling en vervolgens licht herstel zien tussen 2006-20132017. Eerder suggereerden De Boer et al. (2014) dat de daling in 2013 veroorzaakt zou kunnen zijn doordat respondenten in 2013 het voorvoegsel 'bijv.' in de vraag over het hoofd hebben gezien en dus vooral mensen die lid waren van Natuurmonumenten of een Provinciaal Landschap in 2013 'ja' hebben geantwoord. Om hier een beter zicht op te krijgen zijn de bevindingen uit de draagvlakenquête vergeleken met landelijke cijfers over lidmaatschappen uit het Compendium voor de Leefomgeving over de periode 2006-2016 (figuur 6.14). Landelijke cijfers over $2017^{4}$ zijn niet voorhanden.

De vergelijking maakt duidelijk dat de forse daling in ledenaantallen volgens de draagvlakenquête van $36 \%$ tussen 2006-2013 in veel beperktere mate (namelijk een daling van 10\%) terugkomt in de landelijke cijfers van het Compendium van de Leefomgeving (CLO), zie CBS et al. (2017). Tussen 2013 en 2017 is er volgens de draagvlakenquête sprake van een stijging in leden van $22 \%$, waar het CLO in de periode $2013-2016^{5}$ een kleine daling van $4 \%$ laat zien. Kortom, de daling in ledenaantallen zien we in veel beperktere mate terug in de gegevens van het CLO, het herstel niet. Het lijkt er dus inderdaad op dat de andere vraagformulering in 2013 dit heeft veroorzaakt.

\subsubsection{Landelijk beeld: financiële bijdrage aan natuur}

Iets minder dan de helft van de burgers heeft het afgelopen jaar een financiële bijdrage aan de natuur geleverd. Dit deed men vooral door producten te kopen met een keurmerk (30\%). Daarnaast gaf $20 \%$ extra geld voor natuurbescherming (zie tabel 6.6). Andere financiële acties zoals groene beleggingen, meedoen aan adoptieactie, een certificaat kopen, scoren zeer laag.

Tabel 6.6 Financiële bijdrage aan natuur (\%).

\begin{tabular}{lr}
\hline Type bijdrage* & $\%$ \\
\hline Producten gekocht met keurmerk (Eco, FSC, etc.) & 30 \\
\hline Een extra bedrag voor natuurbescherming gegeven & 20 \\
\hline Groen belegd & 4 \\
\hline Aan een adoptieactie meegedaan (kip, kalf, koe, akkerrand, boom, etc.) & 2 \\
\hline Certificaat voor bosaanplant gekocht ter compensatie van vliegreizen (bijv. via Green Seats) & 1 \\
\hline Anders & 4 \\
\hline Nee, geen van deze & 55 \\
\hline Meerdere antwoorden mogelijk
\end{tabular}

Ouderen hebben vaker dan jongeren een extra bedrag voor natuurbescherming gegeven.

Hoogopgeleiden hebben vaker een product met keurmerk gekocht, een bedrag gegeven en vaker belegd dan laagopgeleiden. Autochtonen hebben deze drie activiteiten ook vaker dan allochtonen gedaan. Stedelingen hebben vaker groen belegd dan niet-stedelingen.

\subsubsection{Provincies: financiële bijdrage aan natuur}

Het aantal inwoners dat geen financiële bijdrage aan natuur geeft, loopt uiteen van $60 \%$ in Limburg tot $48 \%$ in Utrecht. Het kopen van ecoproducten en een extra bedrag geven aan natuurbescherming wordt het meest in de provincie Utrecht gedaan, zie figuur 6.15.

\footnotetext{
${ }^{4}$ Voor Overige natuurorganisaties komen de meest recente gegevens uit 2015

${ }^{5}$ Voor Overige natuurorganisaties baseren we ons op de cijfers uit 2015
} 


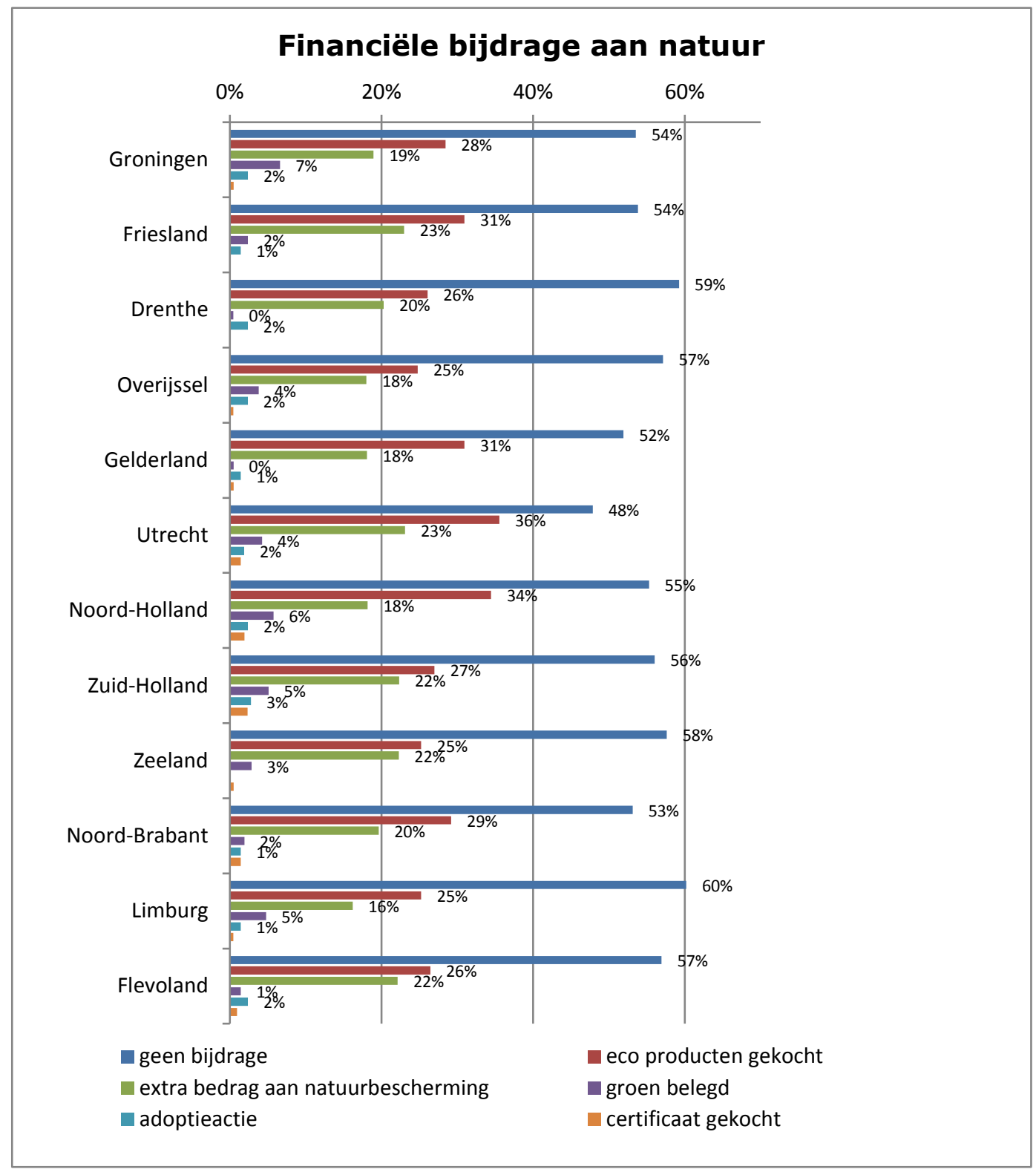

Figuur 6.15 Percentage Nederlanders dat financieel bijdraagt aan natuur per provincie.

\subsubsection{Vergelijking met eerdere jaren}

In 2013 is bijna dezelfde vraag gesteld. Het enige verschil is de opname in 2013 van het woordje extra in de antwoordcategorie: 'Een extra bedrag voor natuurbescherming gegeven'. De vraag van 2013 is gelijk aan die van 2006. In 2001 is deze vraag niet gesteld en in 1996 dusdanig anders (bereidheid) dat een vergelijking niet mogelijk is.

Het percentage burgers dat op de een of andere manier financieel bijdraagt aan natuur is in 2017 (significant) afgenomen ten opzichte van eerdere jaren: in 2006, 2013 en 2017 ging het respectievelijk om $50 \%, 49 \%$ en $45 \%$ van de bevolking, zie figuur 6.16 . In de manier waarop financieel wordt bijgedragen zijn ook verschuivingen zichtbaar. Tussen 2013 en 2017 hebben minder mensen een natuurvriendelijk product gekocht (41\% versus 30\%), terwijl het percentage mensen dat een bedrag heeft gegeven voor natuurbescherming is toegenomen: van 12 naar $20 \%$. Hiermee is in 2017 ten opzichte van 2006 ook sprake van een toename. Tot slot hebben in de periode 2013-2017 minder mensen (van 4\% naar 2\%) meegedaan aan een adoptieactie (zie ook bijlage 4). 


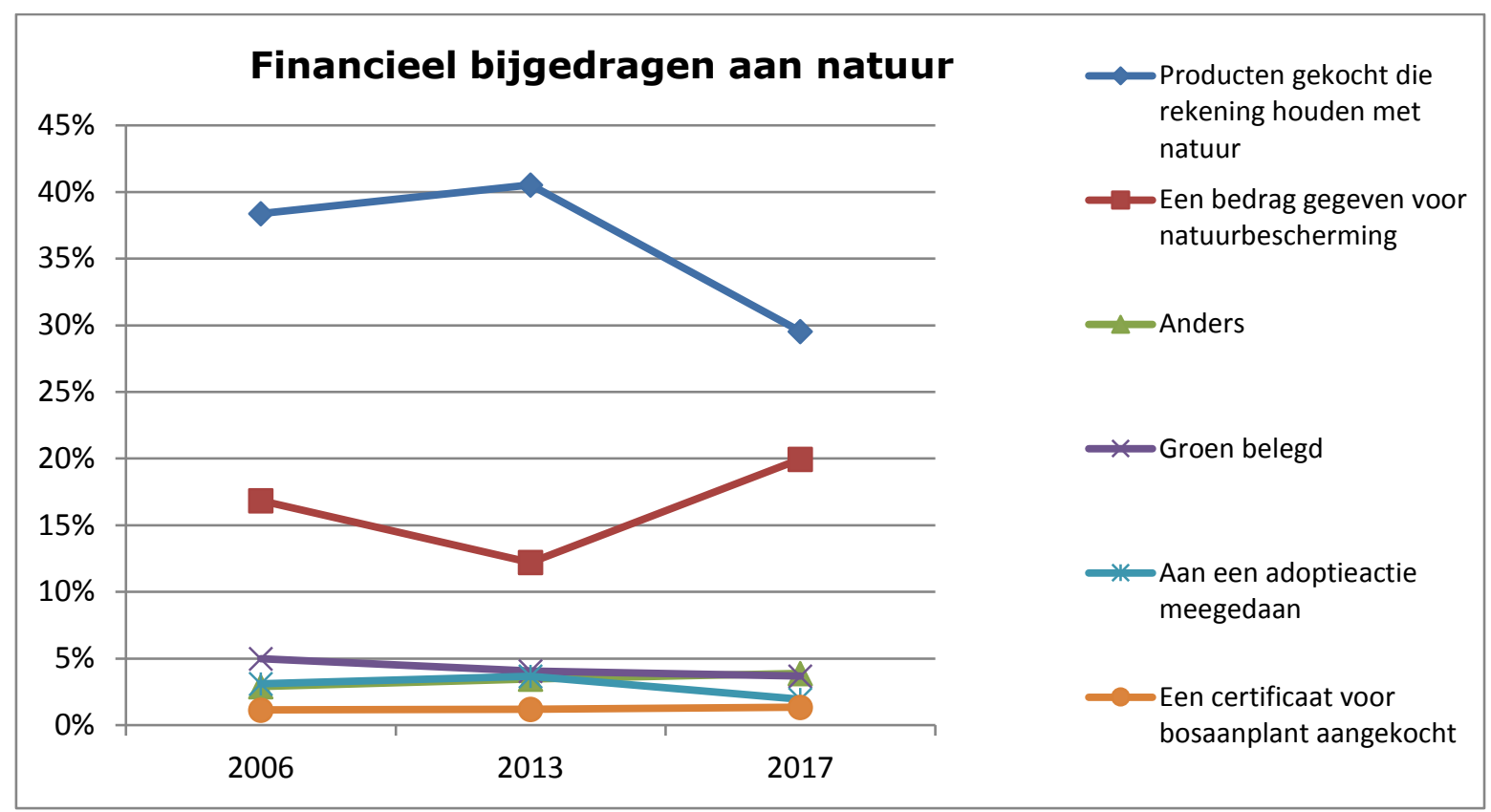

Figuur 6.16 Percentage Nederlanders dat een financiële bijdrage heeft gegeven aan natuur in 2006, 2013 en 2017

\subsection{Burger als medebeslisser}

\subsubsection{Landelijk beeld: ondernomen activiteiten om besluitvorming over natuur te beïnvloeden}

Burgers zijn ook actief bij besluitvorming over natuur en groen in de woonomgeving. Aan de bevolking is gevraagd welke activiteiten ze in dit kader het afgelopen jaar hebben ondernomen. Een derde van de burgers is op enigerlei wijze actief geweest (zie tabel 6.7). Daarvan hebben de meeste mensen één activiteit gedaan. De populairste activiteit was het onderwerp natuur mee laten wegen in de stemkeuze $(18 \%)$ en een handtekening zetten voor de natuur $(13 \%)$. Slechts enkele burgers voeren actie of klimmen in de pen.

Tabel 6.7 Ondernomen activiteiten om besluitvorming over natuur te beïnvloeden (\%).

\begin{tabular}{lc} 
Acties* & $\%$ \\
\hline In mijn stemkeuze het onderwerp natuur mee laten wegen & 18 \\
\hline Handtekening gezet voor de natuur & 13 \\
\hline Naar inspraak- of informatieavond over natuur geweest & 6 \\
\hline Buurtoverleg over groenbeheer bijgewoond & 5 \\
\hline Protestmail gestuurd over de natuur & 3 \\
\hline Actie gevoerd voor meer natuur of behoud van natuur & 3 \\
\hline Brieven of opiniestukken geschreven over natuur & 1 \\
\hline Anders & 1 \\
\hline Geen van deze & 67 \\
\hline
\end{tabular}

* Meerdere antwoorden mogelijk

Meer vrouwen dan mannen hebben een handtekening voor natuur gezet, meer mannen dan vrouwen zijn naar een inspraakavond gegaan. Meer ouderen hebben natuur mee laten wegen in hun stemkeuze, hebben een handtekening voor natuur gezet en zijn vaker dan jongeren naar een inspraakavond geweest. Meer hoger opgeleiden hebben natuur in hun stemkeuze mee laten wegen. Dit geldt ook voor autochtonen in vergelijking tot allochtonen en voor stedelingen in vergelijking tot niet-stedelingen. 


\subsubsection{Provincies: ondernomen activiteiten om besluitvorming over natuur te beïnvloeden}

Het percentage burgers dat geen activiteiten heeft ondernomen om besluitvorming over natuur te beïnvloeden loopt uiteen van $61 \%$ in Groningen tot $74 \%$ in Zeeland. In Drenthe en Utrecht heeft een vijfde van de burgers in zijn stemkeuze het onderwerp natuur mee laten wegen, zie figuur 6.17.

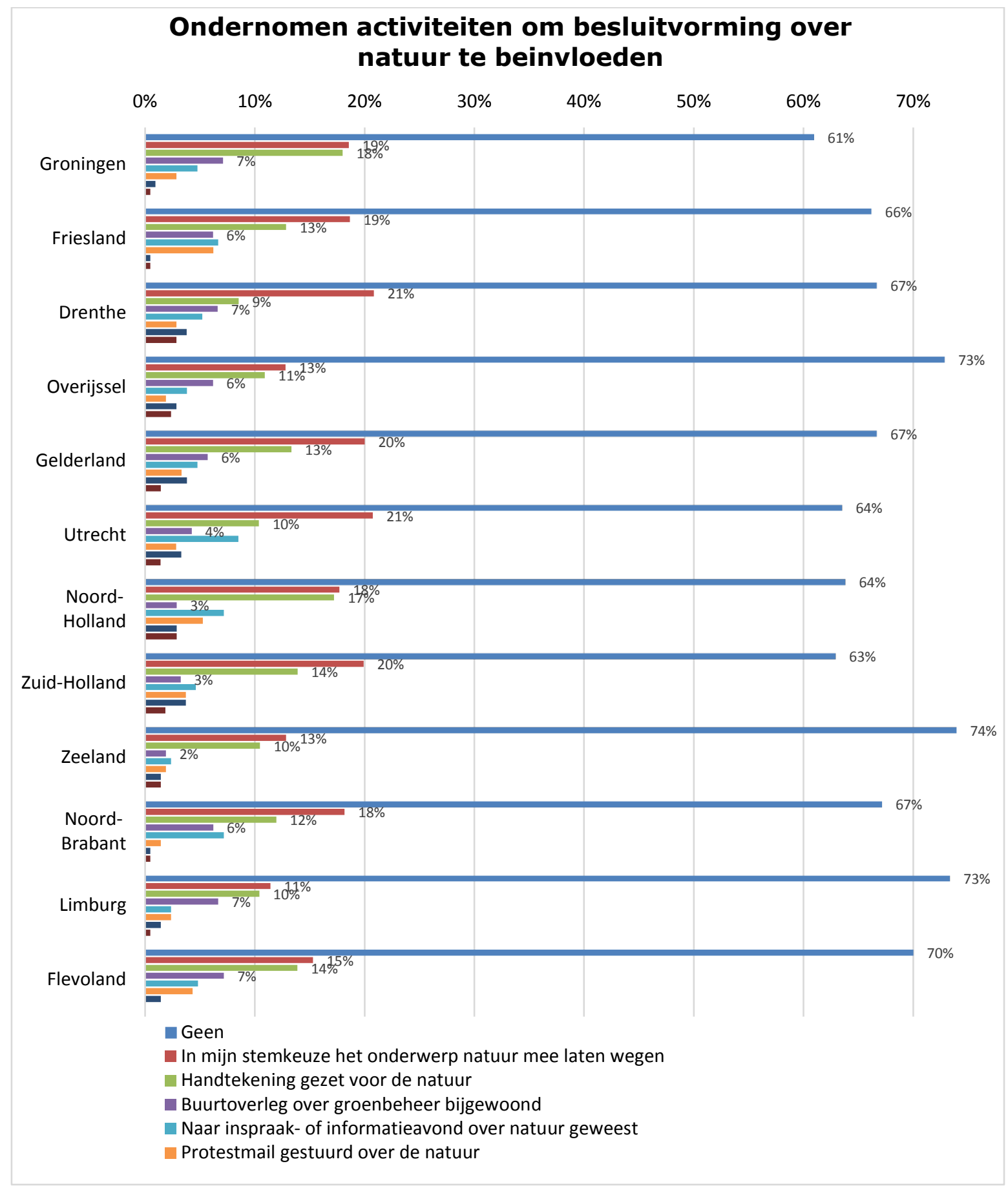

Figuur 6.17 Percentage Nederlanders dat activiteiten heeft ondernomen om besluitvorming over natuur te beïnvloeden per provincie.

\subsubsection{Vergelijking met eerdere jaren}

De vraag over activiteiten die verband houden met besluitvorming over natuur is in 2013 voor het eerst gesteld. In 2017 is de vraag iets aangepast: de zinsnede 'voor plannen voor natuur' is toegevoegd. Ook is in 2017 een antwoordcategorie toegevoegd: In mijn stemkeuze het onderwerp natuur mee laten wegen. 
In figuur 6.18 zijn de zes categorieën activiteiten weergegeven die zowel in 2013 als in 2017 zijn voorgelegd. In grote lijn doen zich geen verschuivingen voor. Significant is de toename van het aandeel van de bevolking dat actie heeft gevoerd, van 1\% in 2013 naar 3\% in 2017. Het aandeel van de bevolking dat aangeeft geen van de bevraagde categorieën te hebben ondernomen is afgenomen: van 79\% in 2013 naar 67\% in 2017 (zie ook bijlage 4). Het is aannemelijk dat deze afname samenhangt met de in 2017 toegevoegde antwoordoptie over stemkeuze. Deze optie is van alle antwoordmogelijkheden het meest aangekruist, mogelijk ook vanwege de Tweede Kamerverkiezing die in het voorjaar van 2017 plaatsvond.

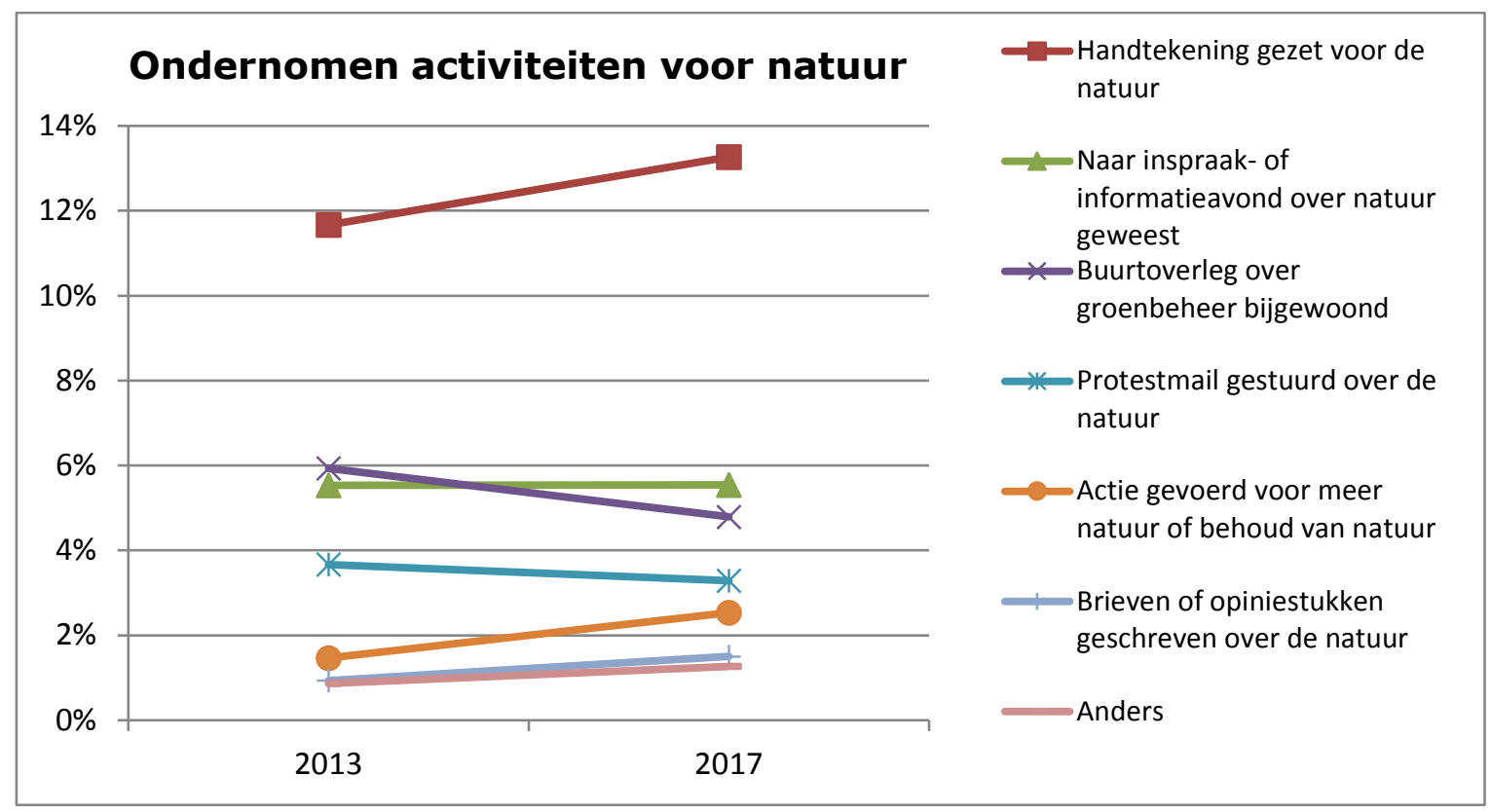

Figuur 6.18 Percentage Nederlanders dat activiteiten voor natuur heeft gedaan om bes/uitvorming over natuur te beïnvloeden in 2013 en 2017.

\subsubsection{Landelijk beeld: kennis van burgerinitiatieven op het gebied van natuur en landschap}

Aan de bevolking is gevraagd of ze projecten op het gebied van natuur en landschap in hun woonplaats kennen, waarbij burgers het initiatief hebben genomen. $61 \%$ kent dergelijke initiatieven niet, $20 \%$ wel en $19 \%$ weet het niet.

Meer mannen dan vrouwen geven aan groene burgerinitiatieven te kennen. Ook meer ouderen en hoger opgeleiden kennen groene burgerinitiatieven. Lager opgeleiden geven vaker het antwoord weet ik niet.

\subsubsection{Provincies: kennis van burgerinitiatieven op het gebied van natuur en landschap}

Figuur 6.19 laat zien dat in Gelderland, Overijssel, Utrecht en Limburg een kwart van de bevolking burgerinitiatieven kent op het gebied van natuur en landschap. In Friesland en Zuid-Holland is men het minst op de hoogte van dergelijke initiatieven. 


\section{Kent u burgerinitiatieven op gebied van natuur en landschap in uw woonplaats?}

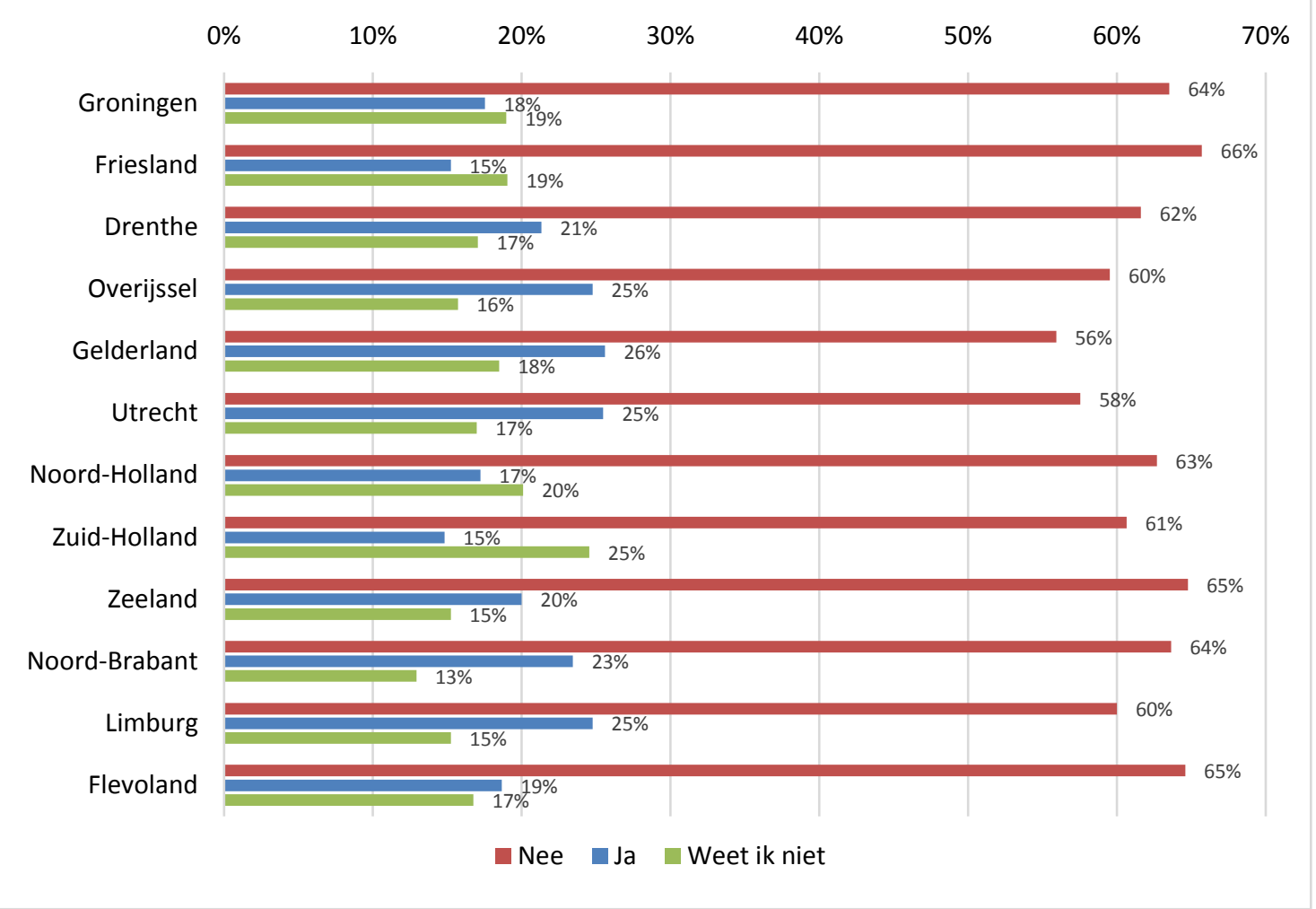

Figuur 6.19 Percentage Nederlanders dat burgerinitiatieven kent op het gebied van natuur en landschap in de woonplaats per provincie.

\subsubsection{Vergelijking met eerdere jaren}

De vraag over kennis van groene burgerinitiatieven is in 2013 voor het eerst gesteld. In 2017 is de vraag enigszins aangepast: de zinsnede 'om het groen/natuur te verbeteren of te beschermen' is toegevoegd.

Figuur 6.20 geeft het beeld voor 2013 en 2017. Het aantal mensen dat geen groene burgerinitiatieven kent in deze periode afgenomen, van 67\% in 2013 naar 61\% in 2017 (zie ook bijlage 4).

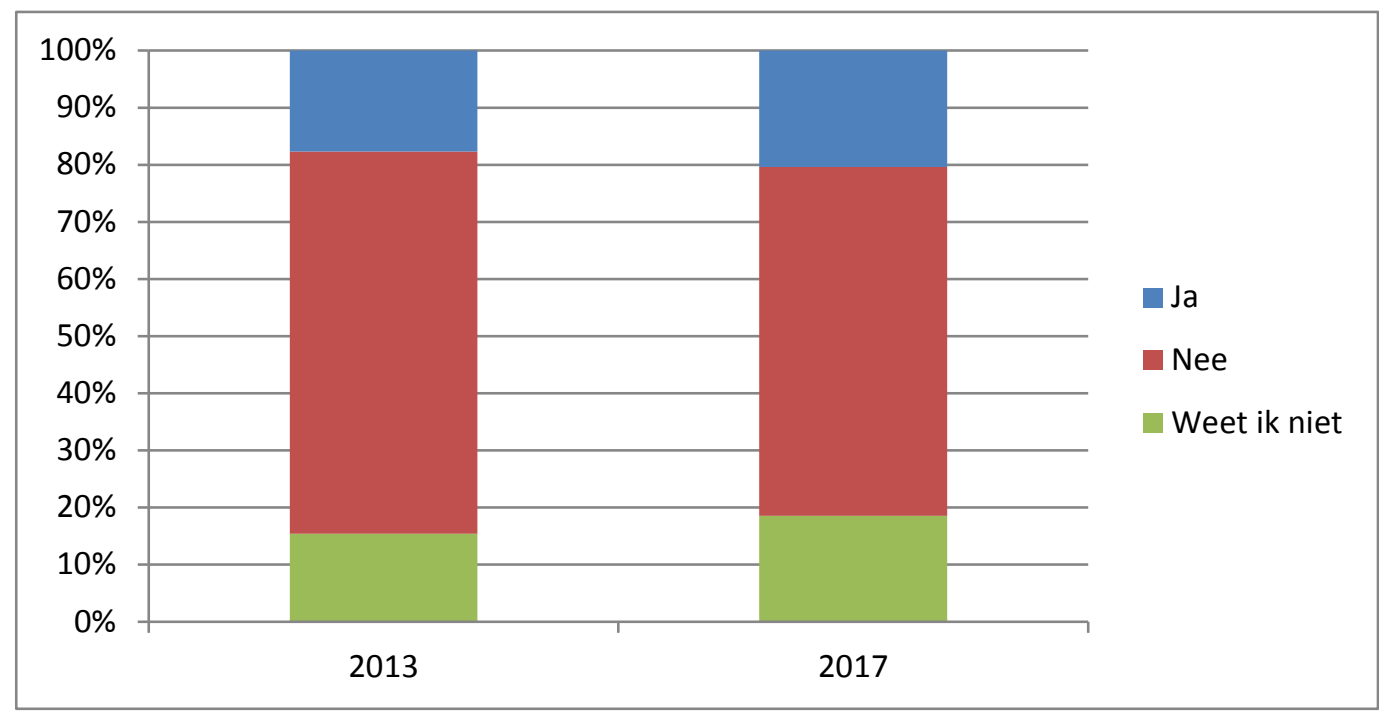

Figuur 6.20 Bekendheid van Nederlanders met groene burgerinitiatieven in 2013 en 2017. 


\subsubsection{Landelijk beeld: soort initiatieven die men kent}

Aan de burgers die een project kennen $(\mathrm{N}=514)$, is ook gevraagd om aan te geven om welk soort initiatieven het gaat. Ruim de helft van de genoemde initiatieven heeft betrekking op beheer en onderhoud. $43 \%$ noemt initiatieven op het gebied van realisatie van groen, $22 \%$ educatieve activiteiten en $20 \%$ initiatieven gericht op actievoeren, zie tabel 6.8 .

Tabel 6.8 Soorten burgerinitiatieven die men aangeeft te kennen (\%, $N=514$ ).

\begin{tabular}{lc} 
Soorten burgerinitiatieven* & $\%$ \\
Het initiatief heeft betrekking op beheer en onderhoud (opruimen van afval, wilgen & 53 \\
knotten, poelen schonen) & 43 \\
\hline Het initiatief heeft betrekking op realisatie van nieuw groen (bijv. planten van bomen, \\
$\begin{array}{l}\text { inrichten van tuinen, bouwen vogelkijkhut) } \\
\text { Het initiatief heeft betrekking op educatieve activiteiten (bijv. excursies, lezingen) }\end{array}$ \\
\hline $\begin{array}{l}\text { Het initiatief heeft betrekking op actievoeren (bijv. protestacties, inzamelen } \\
\text { handtekeningen) }\end{array}$ & 22 \\
\hline Andersoortig initiatief & 8 \\
\hline Meerdere antwoorden mogelijk & 20 \\
\hline
\end{tabular}

Meer mannen dan vrouwen zijn bekend met initiatieven rond de realisatie van nieuw groen. Jongeren zijn vaker bekend met actievoeren, terwijl ouderen meer bekend zijn met initiatieven in het educatieve domein. Hoger opgeleiden zijn meer bekend met initiatieven rond actievoeren en dat geldt ook voor stedelingen in vergelijking tot niet-stedelingen. Meer niet-stedelingen kennen initiatieven met betrekking tot beheer en onderhoud.

\subsubsection{Provincies: soort initiatieven die men kent}

In Drenthe kent 62\% initiatieven op het gebied van beheer en onderhoud. In Zuid-Holland is dit $61 \%$, zie figuur 6.21 .

\subsubsection{Landelijk beeld: betrokkenheid bij burgerinitiatieven}

Aan de burgers die een project kennen $(\mathrm{N}=514)$, is ook gevraagd om aan te geven of en op welke wijze men betrokken is bij het initiatief. 39\% geeft aan niet betrokken te zijn. Burgers die betrokken zijn, zijn dat vooral door informatie te ontvangen (9\%), 3\% werkt mee aan de uitvoering en $1 \%$ behoort tot de initiatiefnemers. Zie tabel 6.9.

Tabel 6.9 Wijze van betrokkenheid bij genoemde initiatieven (\%, $N=514)$.

\begin{tabular}{lrrr} 
Whjze van betrokkenheid* & $\%$ & $\%$ van respons (2525) \\
Ik ben (één van de) initiatiefnemer(s) & $7 \%$ & 34 & $1 \%$ \\
\hline Ik ontvang informatie over het initiatief & $43 \%$ & 224 & $9 \%$ \\
\hline Ik werk mee aan de uitvoering van het initiatief & $17 \%$ & 86 & $3 \%$ \\
\hline Geen van deze & $39 \%$ & 202 & $8 \%$ \\
\hline
\end{tabular}

* Meerdere antwoorden mogelijk

Meer ouderen dan jongeren ontvangen informatie. Allochtonen zijn vaker één van de initiatiefnemers, autochtonen ontvangen vaker informatie en werken ook vaker mee. 


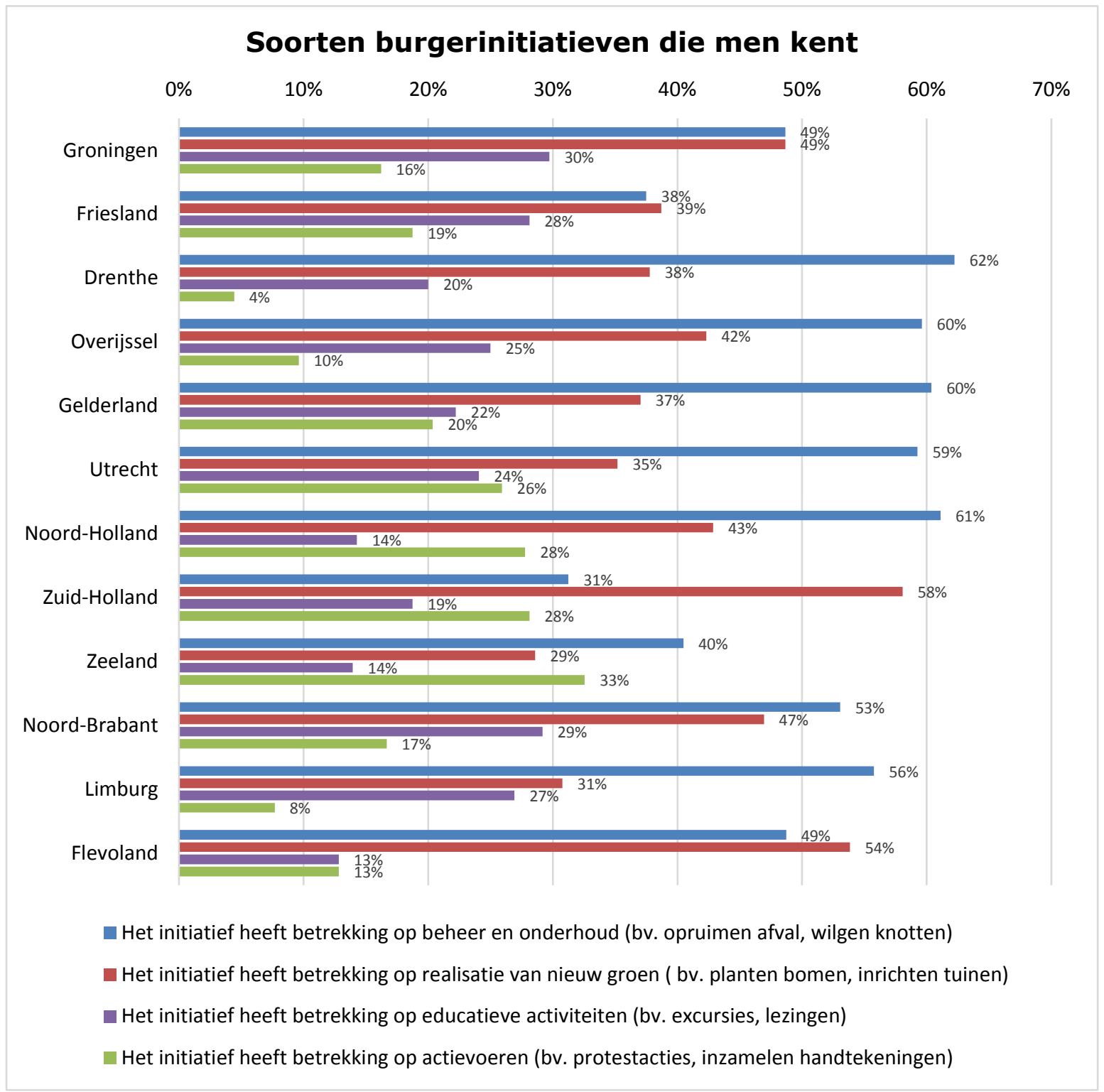

Figuur 6.21 Bekendheid met soorten burgerinitiatieven per provincie ( $N=\leq 57$ per provincie)

\subsubsection{Provincies: betrokkenheid bij burgerinitiatieven}

Het percentage inwoners dat informatie ontvangt over burgerinitiatieven varieert van $31 \%$ in ZuidHolland en Overijssel tot 52\% in Noord-Brabant en Friesland. In Zuid-Holland heeft het hoogste percentage initiatiefnemers ( $9 \%)$, zie figuur 6.22 .

\subsubsection{Vergelijking met eerdere jaren}

In 2013 is de vraag over betrokkenheid bij burgerinitiatieven voor het eerst gesteld. Eén van de antwoordmogelijkheden uit 2013 is in 2017 afgevallen: 'Ik denk mee over het initiatief'. Ook is de antwoordmogelijkheid veranderd: in 2013 kon men slechts één van de (toen) vijf antwoordmogelijkheden aanvinken, in 2017 zijn meerdere antwoorden mogelijk. Een ander belangrijk verschil is dat de vraag in 2013 aan alle respondenten is gesteld, terwijl deze in 2017 enkel is voorgelegd aan de respondenten die op de voorgaande vraag aangaven groene initiatieven te kennen. De data van 2013 is gecorrigeerd, door ook voor deze jaargang enkel de antwoorden mee te nemen van respondenten die een groen initiatief kennen, om vergelijking met 2017 mogelijk te maken. 


\section{Wijze van betrokkenheid bij burgerinitiatieven}

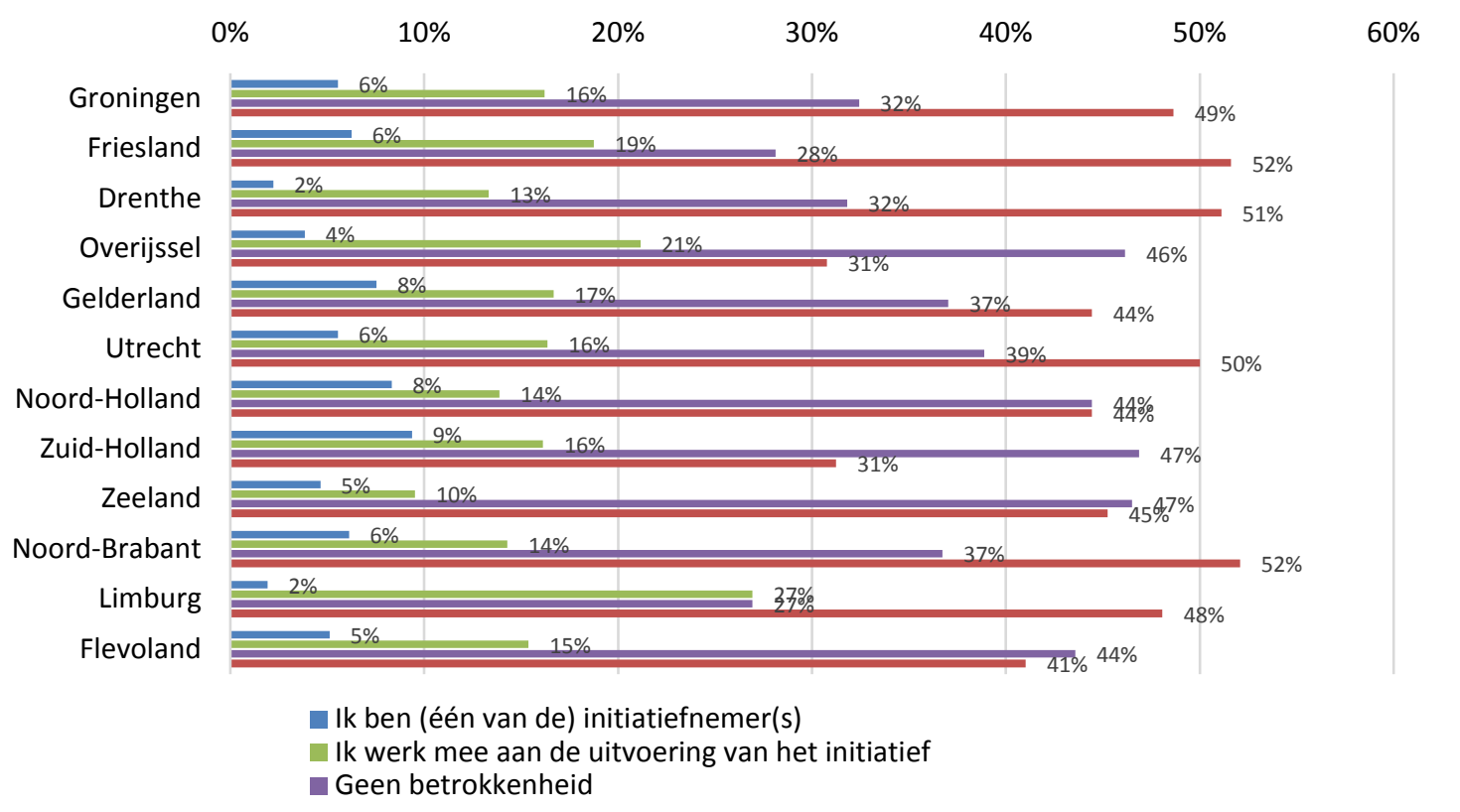

Figuur 6.22 Wijze van betrokkenheid bij burgerinitiatieven per provincie ( $N=\leq 57$ per provincie).

Figuur 6.23 laat zien wat voor een betrokkenheid de mensen hebben, die eerder hebben aangegeven bekend te zijn met groene burgerinitiatieven. De figuur laat zien dat de betrokkenheid lijkt toegenomen: waar in 2013 51\% antwoordde met 'geen van deze' is dat in 2017 gedaald naar 39\%. Mensen hebben vaker 'ik ontvang informatie' aangekruist, en ook meewerken én initiatief nemen doen ze vaker. Of deze toenames samenhangen met de andere vraagstelling is lastig te zeggen. Een analyse naar het aantal mensen dat in 2017 meerdere typen betrokkenheid heeft aangevinkt ${ }^{6}$ is gedaan om hier meer zicht op te krijgen. In beperkte mate lijkt de andere vraagstelling consequenties te hebben gehad: $10 \%(n=31)$ van de 312 mensen die in 2017 op één of andere manier betrokken waren, hebben meer typen betrokkenheid aangevinkt, waar dat in 2013 niet mogelijk was. Door de andere vraagstelling liggen de percentages in 2017 automatisch hoger. Deze 10\% kan echter niet de toename van het aandeel mensen dat informatie ontvangt (van 31\% naar 44\%) en van het aandeel dat meewerkt aan de uitvoering (van $6 \%$ naar $17 \%$ ) verklaren. Het lijkt er dus op dat in de afgelopen jaren de betrokkenheid van mensen die bekend zijn met groene burgerinitiatieven sterk is gegroeid

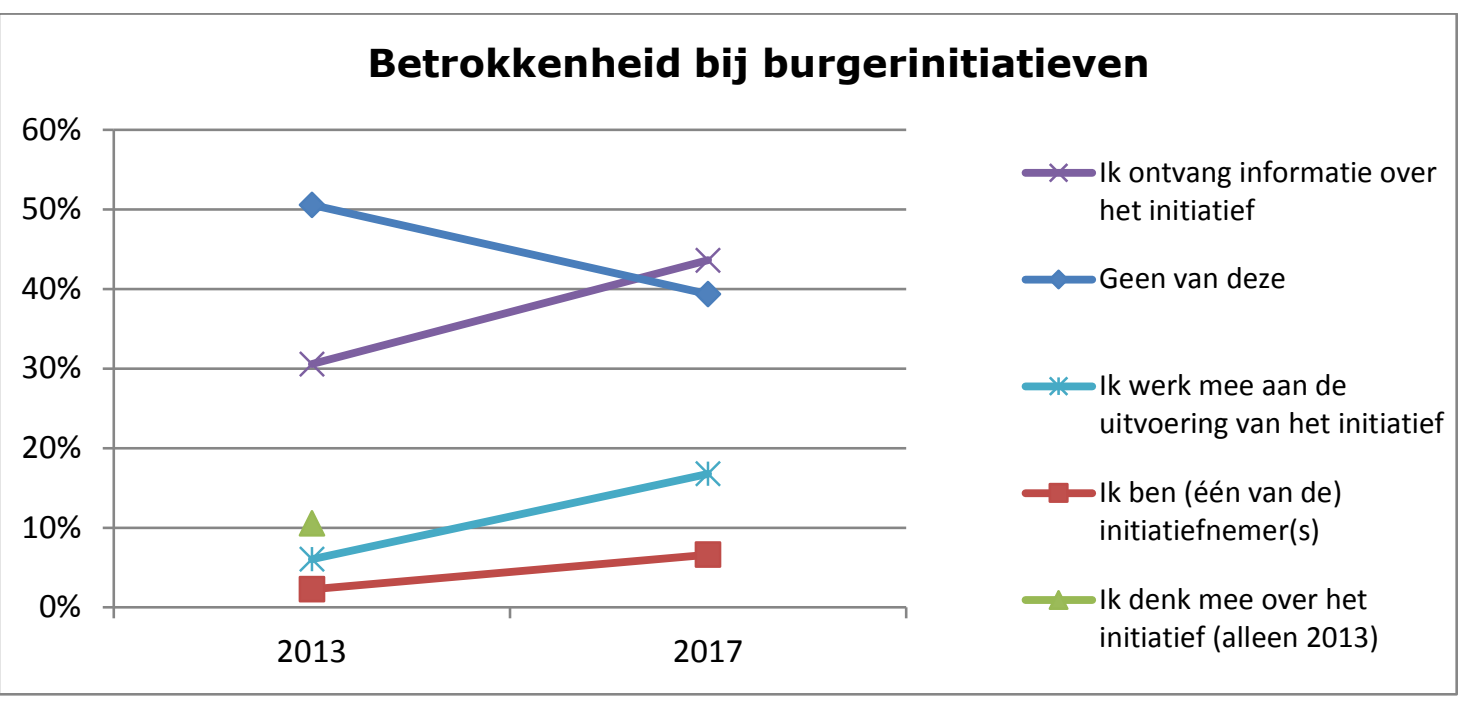

Figuur 6.23 Type betrokkenheid bij groene burgerinitiatieven van burgers die hiermee bekend zijn in 2013 en 2017

\footnotetext{
${ }^{6}$ Geen van deze is buiten beschouwing gelaten in deze analyse
} 


\subsection{Een indeling van burgers naar betrokkenheid bij natuur}

\subsubsection{Landelijk beeld}

In de vorige paragrafen is besproken in welke mate de bevolking betrokken is bij de natuur als gebruiker, beschermer en beslisser. In deze paragraaf maken we in een aantal stappen een indeling van de Nederlandse bevolking naar betrokkenheid bij natuur, waarbij alle activiteiten die burgers ondernemen op het gebied van gebruiken, beschermen en beslissen zijn meegenomen. In bijlage 5 staat de uitgebreide werkwijze.

Stap 1: In de domeinen gebruiker, beschermer en beslisser wordt onderscheid gemaakt in de mate betrokkenheid: passief en actief met behulp van verschillende indicatoren.

De gebruiker actief duiden we aan de hand van zijn bezoek aan natuur. Bij de gebruiker passief gaat het om het gebruik van informatiebronnen over natuur.

De beschermer actief wordt gekenmerkt door activiteiten voor natuur- en landschapsbeheer, en het meewerken aan een burgerinitiatief. De beschermer passief karakteriseren we aan de hand van lidmaatschap van natuurorganisaties en de financiële bijdrage voor natuur.

Bij de beslisser actief gaat het om activiteiten voor natuur- en landschap gericht op beïnvloeding van besluitvorming (zoals naar inspraakavond, actievoeren, brief schrijven) en actief als initiatiefnemer van een burgerinitiatief. Een beslisser passief duiden we aan de hand van een groene stemkeuze en een handtekening zetten voor de natuur (zie tabel 6.10).

Tabel 6.10 Indicatoren voor vormen van burgerbetrokkenheid bij natuur.

\begin{tabular}{|c|c|c|c|}
\hline $\begin{array}{l}\text { Mate van } \\
\text { betrokkenheid }\end{array}$ & Gebruiker & Beschermer & Beslisser \\
\hline Actief & $\begin{array}{l}\text { *Bezoek aan groen in de } \\
\text { stad, platteland, natuur- } \\
\text { gebied }\end{array}$ & $\begin{array}{l}\text { *Activiteiten voor natuur- } \\
\text { en landschapsbeheer } \\
\text { *Actief in burgerinitiatief: ik } \\
\text { werk mee aan uitvoering } \\
\text { burgerinitiatief }\end{array}$ & $\begin{array}{l}\text { *Activiteiten voor natuur- } \\
\text { en landschap gericht op } \\
\text { beïnvloeding van besluit- } \\
\text { vorming (minus stemgedrag } \\
\text { en handtekening) } \\
\text { *Actief in burgerinitiatief: ik } \\
\text { ben een van de } \\
\text { initiatiefnemers }\end{array}$ \\
\hline Passief & $\begin{array}{l}\text { *Gebruik informatiebronnen } \\
\text { over natuur }\end{array}$ & $\begin{array}{l}\text { *Lidmaatschap } \\
\text { natuurorganisaties } \\
\text { *Financiële bijdrage voor } \\
\text { natuur }\end{array}$ & $\begin{array}{l}\text { *Activiteiten voor natuur- } \\
\text { en landschap gericht op } \\
\text { beïnvloeding van besluit- } \\
\text { vorming: groen stemmen } \\
\text { en handtekening zetten } \\
\text { * Ik ontvang informatie } \\
\text { over het initiatief }\end{array}$ \\
\hline
\end{tabular}

\section{Stap 2: De indicatoren voor burgerbetrokkenheid worden teruggebracht tot één indicator per domein (bijv. beschermer actief). Iedere indicator heeft drie of vier categorieën voor de mate van betrokkenheid.}

We onderscheiden gebruiker actief, gebruiker passief, beschermer actief, beschermer passief, beslisser actief en beslisser passief. Bij elk van deze zes vormen (met uitzondering van beslisser passief) onderscheiden we drie tot vier categorieën, waarbij 1 staat voor 'zelden of nooit betrokken' en 4 staat voor 'vaak tot zeer vaak betrokken'.

Figuur 6.24 geeft weer hoe Nederlanders betrokken zijn bij natuur en landschap voor de zes vormen van burgerbetrokkenheid. De Nederlanders zijn het meest betrokken als gebruiker van natuur en landschap: $68 \%$ is redelijk tot zeer betrokken bij natuurbezoek (als gebruiker actief) en als gebruiker passief is $48 \%$ redelijk tot zeer betrokken bij het gebruiken van informatie over natuur. 


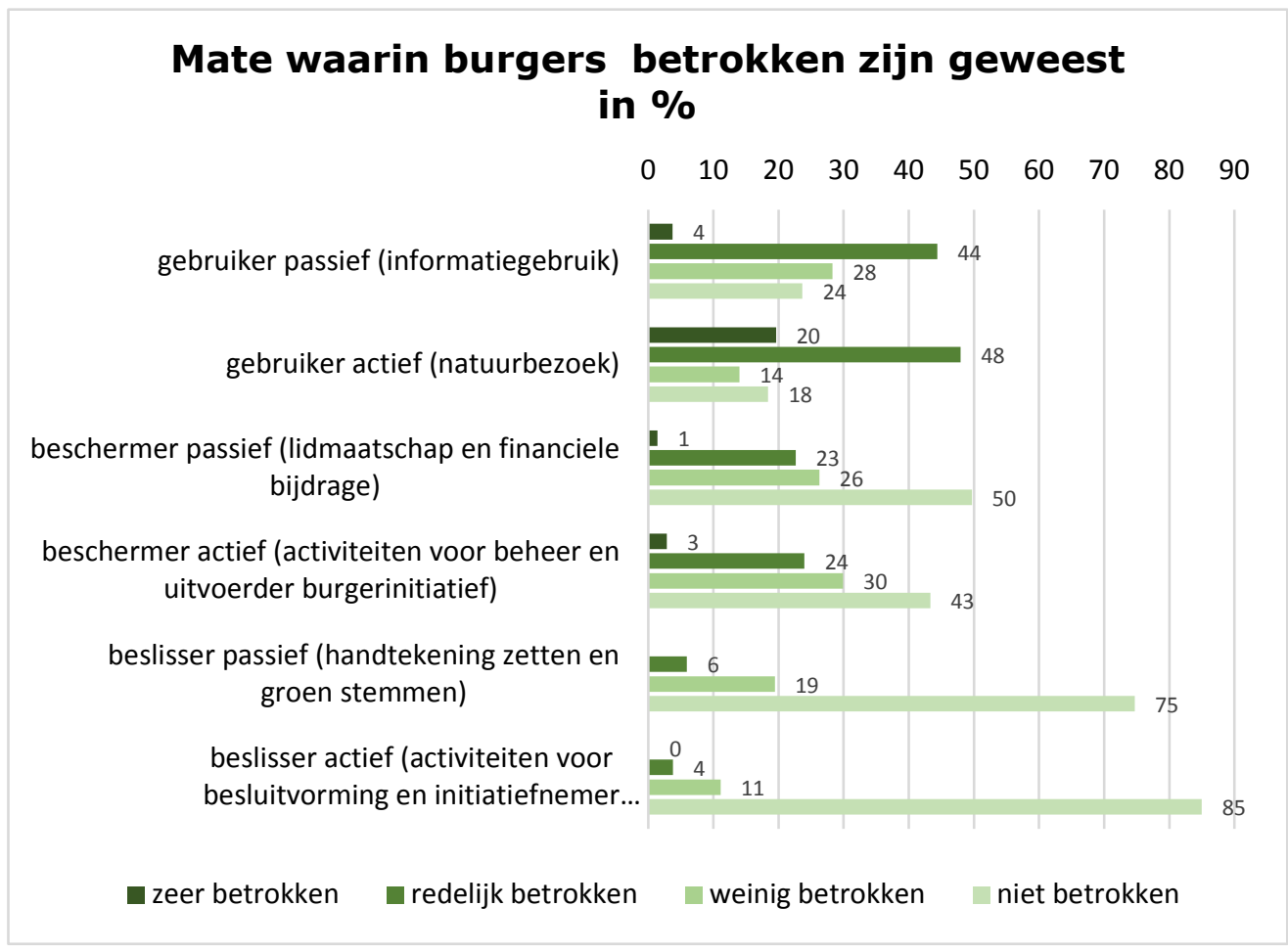

Figuur 6.24 Mate waarin en wijze waarop burgers betrokken zijn geweest bij natuur en landschap

Als beschermer van natuur zijn Nederlanders minder intensief betrokken: $73 \%$ is als beschermer actief weinig of niet betrokken bij activiteiten voor natuur- en landschapsbeheer. Een kwart is hierbij redelijk betrokken. Van de beschermer passief is $76 \%$ weinig of niet betrokken als het gaat om een financiële bijdrage voor natuur of lidmaatschap van een natuurorganisatie. Bijna een kwart is als beschermer actief of passief redelijk betrokken.

Het minst betrokken zijn de Nederlanders als beslisser. Van de beslissers actief is $85 \%$ niet betrokken bij activiteiten om besluitvorming over natuur te beïnvloeden. Slechts $4 \%$ is hierbij redelijk betrokken. Van de beslisser passief is $75 \%$ niet betrokken. Men zet geen handtekening voor natuur of houdt bij zijn stemkeuze rekening met natuur.

\section{Stap 3: De Nederlandse bevolking wordt ingedeeld in vier groepen op basis van de scores op zes indicatoren.}

Om de bevolking in te kunnen delen naar de mate van betrokkenheid, is nagegaan hoe hoog men 'scoort' op de zes indicatoren van betrokkenheid. Respondenten die hoog scoren zijn meer betrokken dan mensen die minder hoog scoren (zie bijlage 5 voor de werkwijze). Dit leidt tot een indeling van de Nederlandse bevolking in vier groepen van betrokkenheid (figuur 6.25).

\section{Nederlandse bevolking naar betrokkenheid bij natuur}

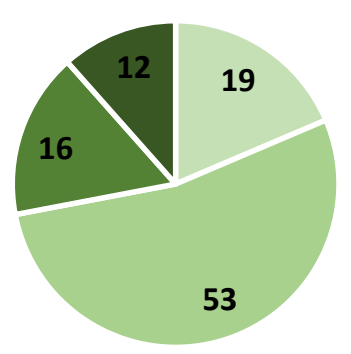

weinig betrokken - matig betrokken - redelijk betrokken $n$ zeer betrokken

Figuur 6.25 Indeling van de Nederlandse bevolking naar mate van betrokkenheid bij natuur (\%). 
De groep 'weinig betrokken' $(\mathrm{N}=470 ; 19 \%)$ onderneemt weinig tot niets in de natuur. Ze informeren zich heel af en toe over de natuur of brengen heel soms een bezoek aan groen in de stad, het platteland of een natuurgebied. In deze groep zijn de laagopgeleiden, mensen tot 34 jaar en niet westerse allochtonen oververtegenwoordigd (zie tabel 6.11).

De meeste burgers vallen in de groep 'matig betrokken' $(\mathrm{N}=1349,53 \%)$. Zij bezoeken regelmatig tot vaak een natuurgebied en gebruiken één à twee informatiebronnen over de natuur. Deze groep is nauwelijks actief als beschermer of beslisser: een zeer beperkt deel draagt financieel bij aan natuur en of is actief voor natuur- en landschapsbeheer. Deze groep is qua geslacht, leeftijd, opleiding en herkomst een afspiegeling van de Nederlandse bevolking.

De groep 'redelijk betrokken' $(\mathrm{N}=415 ; 16 \%)$ kenmerkt zich doordat ze regelmatig activiteiten verrichten in twee domeinen, namelijk het domein van de gebruiker en het domein van de beschermer. Zo bezoeken ze vaak natuurgebieden en gebruiken ze minimaal twee informatiebronnen. Daarnaast ondernemen ze regelmatig verschillende activiteiten voor natuur- en landschapsbeheer en dragen ze financieel bij aan natuurbescherming. Ze zijn nauwelijks actief als beslisser. In deze groep zijn ouderen (55-74 jaar) oververtegenwoordigd en allochtonen ondervertegenwoordigd. Opleiding en geslacht wijken niet af van het gemiddelde.

Ten slotte onderscheiden we de groep 'zeer betrokken' ( $N=292 ; 12 \%)$. Deze groep is op alle fronten actief: zowel als gebruiker, beschermer en als beslisser. Qua gebruik van informatiebronnen en bezoek aan de natuur lijken ze op de groep redelijk betrokken. Maar ze onderscheiden zich van deze groep als beschermer: ze ondernemen veel verschillende activiteiten voor natuur- en landschapsbeheer en ze geven op meerdere manieren financiële steun aan natuur. Als beslisser is deze groep ook actief: ze participeren in besluitvorming rondom natuur en landschap (bv. door een handtekening te zetten voor natuur, een buurtoverleg over groenbeheer bij te wonen of door initiatiefnemer te zijn in een burgerinitiatief op het gebied van natuur en landschap). In deze groep zijn ouderen (55-74 jaar), hoogopgeleiden en mannen oververtegenwoordigd.

Tabel 6.11 Gemiddelde scores van de vier groepen burgers op een schaal van 1 - 4*.

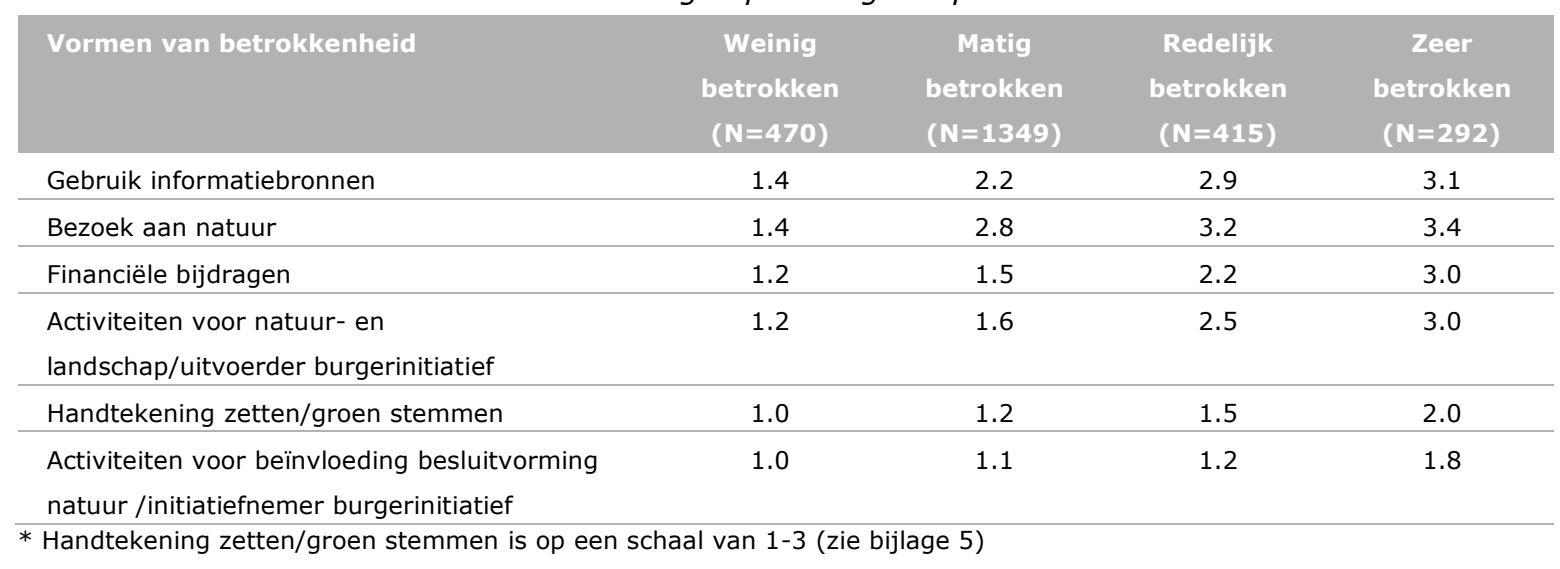

\subsubsection{Vergelijking met eerdere jaren}

In 2013 is voor het eerst segmentatie van betrokkenheid bij natuur van de Nederlandse bevolking gemaakt. Destijds was $21 \%$ weinig actief betrokken, $52 \%$ matig actief betrokken, $16 \%$ actief betrokken en $11 \%$ niet betrokken. Deze percentages komen redelijk overeen met die van de groepen in 2017. In 2017 zijn er echter een paar wijzigingen geweest in de onderliggende vragen en antwoordcategorieën zodat een absolute vergelijking niet mogelijk is, maar de trend lijkt niet veel veranderd. 

Aan de hand van de drie indicatoren voor maatschappelijk draagvlak: belang van natuurbehoud, steun voor natuurbeleid en betrokkenheid bij natuur, worden in dit hoofdstuk de belangrijkste conclusies vermeld. In paragraaf 7.1 staan de kernboodschappen over draagvlak voor natuur. In paragraaf 7.2 gaan we nader in op de belangrijkste bevindingen van het beeld voor 2017. In paragraaf 7.3 worden de trends in de tijd beschreven in het maatschappelijk draagvlak.

\subsection{Kernboodschappen}

\section{Nederlanders vinden natuurbehoud belangrijk, maar zijn ambivalent over het economische belang van natuur}

Het maatschappelijk besef van het belang van natuurbehoud is substantieel en in 2017 toegenomen. Dit blijkt vooral uit het feit dat burgers de aandacht voor natuur belangrijk vinden, dat de overheid geld uitgeeft aan natuurbehoud en dat zij de zorgen over natuur als terecht ervaren. Eén op de drie Nederlanders vindt echter ook dat de natuur geen belemmering mag zijn voor economische vooruitgang. Deze groep is sinds 2006 stabiel. Aan de andere kant kiezen burgers in hun woonomgeving vaker voor het natuurbelang dan het economische belang; zij geven bijvoorbeeld de voorkeur aan meer groen boven meer winkels of woningen en rekeningrijden boven extra wegen. Ook vinden burgers dat geld verdienen met natuur de minst belangrijke functie van natuur is. Natuur voor gezondheid, voor het nageslacht en om van te genieten vindt de Nederlander veel belangrijker.

\section{Nederlanders bezoeken regelmatig natuur en zijn tevreden over de hoeveelheid natuur.} Natuurgebieden worden het meest bezocht, gevolgd door stadsgroen en natuur op het platteland. Sinds 2006 is bezoek aan parken toegenomen, het bezoek aan natuurgebieden schommelt licht tussen de jaren. Burgers ervaren de hoeveelheid natuur in de woonomgeving en in Nederland als ruim voldoende, al zijn inwoners van de vier grote steden, minder tevreden hierover. In vergelijking met 2013 is de mening over de hoeveelheid natuur in de woonomgeving en in Nederland nagenoeg gelijk gebleven.

\section{Nederlanders vinden natuur geen prioritair beleidsthema, maar zien de overheid wel als hoofdverantwoordelijk voor natuur}

Gezondheidszorg, onderwijs en werkgelegenheid zijn door de jaren heen als de belangrijkste beleidsonderwerpen van de overheid genoemd. Het publiek vindt natuur al sinds 2006 één van de minst belangrijke thema's. Deze dalende lijn in prioriteit van natuur heeft zich in 2017 verder doorgezet. Desondanks zien burgers de overheid als de belangrijkste hoofdverantwoordelijke voor natuur, zowel in de stad, als op het platteland en in natuurgebieden. Het publiek vindt zichzelf, natuurorganisaties, (landbouw) bedrijven wel in belangrijke mate medeverantwoordelijk voor natuur.

\section{Het draagvlak voor beleidsmaatregelen om natuur te beschermen is groot en verder toegenomen}

Er is veel draagvlak voor verschillende beleidsmaatregelen om natuur te beschermen en te verbeteren. Het meeste draagvlak bestaat voor het beschermen van bestaande natuurgebieden, het beschermen van zeldzame planten en dieren en het beheren en onderhouden van natuurgebieden. Maar ook maatregelen als bescherming van natuur op het platteland, meer natuureducatie op scholen en het betrekken van bedrijven en burgers en bij natuur kan op grote steun van de bevolking rekenen. Vergeleken met 2013 is het draagvlak voor de meeste maatregelen toegenomen.

\section{Nederlanders vooral betrokken bij natuur door laagdrempelige activiteiten}

De betrokkenheid van het publiek als gebruiker van natuur, beschermer van natuur en medebeslisser over natuur uit zich vooral in laagdrempelige activiteiten. Wat betreft het gebruik bezoekt ongeveer de helft van de Nederlandse bevolking regelmatig natuurgebieden, stadsgroen en het platteland. Het 
gebruik van stadsnatuur neemt sinds 2006 toe. Voor informatie over natuur is televisie nog steeds de belangrijkste bron. Internet, tijdschriften en social media raadpleegt men veel minder, al neemt het gebruik van social media sinds 2013 toe. Net als in 2013 heeft twee derde van de Nederlandse bevolking activiteiten voor natuur en landschapsbeheer verricht. Het gaat dan vooral om het ophangen van nestkastjes en afval van anderen opruimen. Het publiek is veel minder actief bij het onderhoud van natuur en landschap, natuureducatie en natuurinventarisaties. Ongeveer een derde van de bevolking is betrokken bij activiteiten die beslissingen over natuur kunnen beïnvloeden. Ook hier gaat het vooral om laagdrempelige activiteiten zoals bij het stemmen het onderwerp natuur mee laten wegen of een handtekening zetten voor de natuur. De betrokkenheid in de vorm van een buurtoverleg bijwonen, actievoeren voor natuur of meedoen aan een burgerinitiatief, is veel geringer.

\section{De meeste Nederlanders zijn matig betrokken bij natuur}

Op grond van alle activiteiten die de Nederlandse bevolking onderneemt als gebruiker, beschermer en beslisser, zijn vier groepen te onderscheiden. De grootste groep (53\%) is matig betrokken. Dit zijn vooral mensen die natuur bezoeken en zich informeren. Ze doen nauwelijks activiteiten voor natuurbescherming of besluitvorming. Ongeveer 1 op de 10 Nederlanders is zeer betrokken; men is op veel fronten actief voor de natuur. Een vijfde van de Nederlanders is weinig betrokken bij natuur en een iets kleinere groep is vooral betrokken als gebruiker en beschermer. De vier groepen zijn sinds 2013 ongeveer gelijk gebleven. $\mathrm{Er}$ is potentie om de maatschappelijke betrokkenheid van burgers verder te laten groeien, want ruim tachtig procent spreekt het aan om betrokken te zijn bij de natuur. Men zou willen meedenken over plannen voor natuur, informatie ontvangen en zelf aan de slag bij het onderhoud.

\subsection{Het draagvlak voor natuur in 2017}

\section{Belang van natuurbehoud}

Burgers beseffen in belangrijke mate dat het nodig is om natuur te beschermen: een ruime meerderheid vindt de aandacht voor natuur niet overdreven en vindt niet dat we ons te veel zorgen maken over de toekomst van de natuur in Nederland, maar de meningen zijn verdeeld als het gaat over de opvatting dat de natuur geen belemmering mag zijn voor economische vooruitgang.

Tegelijkertijd kiest een meerderheid van de Nederlandse bevolking bij dilemma's tussen natuur en economie, zoals meer winkels of meer groen, meer parkeerplaatsen of meer speelveldjes en bomen voor natuur. Kijken we naar achtergrondkenmerken van mensen, dan blijkt dat vrouwen, hoogopgeleiden, en bewoners van grote steden meer belang hechten aan natuurbehoud. Voor de dilemma's economie versus natuur zien we dat ouderen, hoger opgeleiden en stedelingen meer voor groen gaan dan jongeren, lager opgeleiden en mensen die buiten de grote steden wonen.

Burgers vinden de meeste redenen (gezondheid, het nageslacht, beleving, recreatie, intrinsieke waarde) waarom natuur in Nederland van belang kan zijn, (zeer) belangrijk. Veruit de belangrijkste reden vinden zij gezondheid (bijv. schone lucht) en de minst belangrijke reden vindt men geld verdienen met natuur (bijv. houtproductie). Ouderen kiezen vaker dan andere leeftijdsgroepen voor natuur om van te genieten, natuur voor gezondheid en voor de generatie na ons. Ouderen vinden natuur voor de landbouw meer belangrijk dan jongeren. Lager opgeleiden vinden natuur om van te genieten belangrijker dan hoogopgeleiden, hoogopgeleiden hechten meer belang aan natuur voor de gezondheid. Autochtonen hechten meer dan allochtonen aan natuur voor de volgende generatie.

Onder de Nederlanders leven verschillende ideeën over de wenselijkheid en de mate van menselijk ingrijpen in de natuur. Enerzijds vindt men dat de menselijke invloed gering moet zijn, want een meerderheid komt in de natuur liever geen bebouwing tegen, vindt dat sommige gebieden afgesloten mogen worden om natuur te beschermen en dat de waarde van een natuurgebied toeneemt als het met rust gelaten wordt. Anderzijds is er ook een meerderheid die vindt dat ingrijpen gewenst is als het gaat om het kappen van bomen om het aantal soorten te vergroten, het maaien van bermen en jacht als er overlast is van dieren. Mannen, ouderen en autochtonen zijn minder voor menselijk ingrijpen. 
Een meerderheid van de Nederlanders vindt de hoeveelheid natuur in Nederland en de woonomgeving (ruim) voldoende, waarbij men wel meer tevreden is over de hoeveelheid groen in Nederland. De tevredenheid verschilt per regio. Met name in de grote steden is men veel minder tevreden over de hoeveelheid natuur in Nederland en in de woonomgeving. Ouderen beoordelen de hoeveelheid natuur in de woonomgeving positiever dan andere leeftijdsgroepen. Allochtonen ervaren de hoeveelheid natuur in Nederland ook positiever dan autochtonen. Niet-stedelingen ervaren zowel de hoeveelheid natuur in Nederland als in de woonomgeving als positiever dan inwoners van de grote steden.

\section{Steun voor natuurbeleid}

Natuur is geen prominent beleidsthema voor de Nederlanders. Natuur komt op de laatste plaats als men het belang aan moet geven ten opzichte van andere beleidsthema's. Gezondheidszorg en onderwijs vindt men de belangrijkste onderwerpen. Geslacht, leeftijd en opleidingsniveau zijn van invloed op de voorkeuren voor verschillende onderwerpen; echter voor de prioritering van het onderwerp natuur doen zich geen verschillen voor op basis van achtergrondkenmerken.

De verantwoordelijkheid voor natuurbescherming ligt volgens een meerderheid van de Nederlandse bevolking bij de overheid. Dit geldt voor zowel natuur in natuurgebieden, natuur op het platteland, als natuur in de stad. Natuurorganisaties, (landbouw)bedrijven, en burgers vindt men wel in belangrijke mate medeverantwoordelijk voor natuur. Mannen en jongeren en hoogopgeleiden zien de overheid als meer verantwoordelijk.

Het draagvlak voor verschillende beleidsmaatregelen om natuur te beheren en te verbeteren is groot. De maatregelen waar het meeste draagvlak voor is, zijn het beschermen van bestaande natuurgebieden, het beheer en onderhoud van natuurgebieden, het beschermen van zeldzame flora en fauna en bescherming van natuur op het platteland. Ook ondersteunt een ruime meerderheid het betrekken van bedrijven en burgers bij natuur en meer natuureducatie op scholen. Over onteigening als beleidsmaatregel om natuur te realiseren zijn de meningen verdeeld. Eén op de drie Nederlanders is het hier niet mee eens.

\section{Betrokkenheid bij natuur}

Vier van de vijf Nederlanders spreekt het aan om betrokken te zijn bij de natuur. Die potentiële betrokkenheid uit zich vooral in meedenken met overheden of natuurorganisaties en informatie ontvangen over wat men kan doen. Vrijwilligerswerk is voor een kwart van de Nederlanders een optie. Betrokkenheid bij de eigen woonomgeving en actief en gezond blijven zijn de belangrijkste motieven om betrokken te willen zijn bij de natuur. Ongeveer een vijfde van de Nederlanders wil niet betrokken zijn, omdat zij daar geen tijd voor hebben of omdat zij ander vrijwilligerswerk doen.

\section{Burger als gebruiker}

Een meerderheid van de bevolking bezoekt regelmatig tot vaak natuurgebieden. Het bezoek aan stadsgroen komt op de tweede plaats en daarna het bezoek aan het platteland. Stadsnatuur wordt vaker bezocht door inwoners van de vier grote steden. Leeftijd is van invloed op het bezoek. Ouderen bezoeken parken, platteland en ook stadsgroen vaker dan andere leeftijdsgroepen. Hoogopgeleiden bezoeken stadsgroen vaker dan lager opgeleiden. Autochtonen trekken vaker dan allochtonen naar het platteland en natuurgebieden. Stedelingen bezoeken vaker dan niet-stedelingen stadsparken. Nietstedelingen komen meer dan stedelingen op het platteland en in natuurgebieden.

Driekwart van de Nederlanders gebruikt één of meerdere informatiebronnen om iets over natuur te weten te komen. De tv is hiervoor de belangrijkste bron, gevolgd door het internet.

\section{Burger als beschermer}

Een kleine meerderheid van de bevolking zet zich actief in voor natuurbescherming. Het plaatsen van nestkastjes en afval van anderen in de natuur opruimen zijn de meest genoemde bezigheden.

Onderhoud van natuur en landschap, natuureducatie, natuurinventarisatie of weidevogelbescherming worden weinig gedaan. Tevens geeft iets minder dan de helft van de burgers een financiële bijdrage aan de natuur, vooral door het kopen van producten met een keurmerk (Eco, FSC). Een kwart is lid van een natuurbeschermingsorganisatie. Leden van natuurbeschermingsorganisaties zijn vaker ouder, hoger opgeleid en autochtoon. 


\section{Burger als medebeslisser}

Eén op de drie Nederlanders heeft activiteiten ondernomen om de besluitvorming over natuur te beïnvloeden. Dit gebeurt vooral op een passieve wijze door in de stemkeuze natuur mee te laten wegen of door een handtekening te zetten voor de natuur. Inspraakavonden, buurtoverleg of actie voeren doet men nauwelijks. Meer mannen dan vrouwen willen meedenken, vrouwen willen daarentegen meer dan mannen geïnformeerd worden en ook zelf meedoen met het beheer van buurtgroen. Ouderen willen meer dan jongeren meedenken, jongeren willen meer dan ouderen geïnformeerd worden. Hoogopgeleiden staan meer dan laagopgeleiden open voor meedenken, geïnformeerd worden en zelf buurtgroen onderhouden. Autochtonen willen vaker dan allochtonen meedenken en stedelingen willen meer dan niet-stedelingen geïnformeerd worden.

Twee derde van de bevolking kent geen burgerinitiatieven voor natuur en landschap in de eigen woonplaats. Initiatieven die men wel kent, hebben vooral betrekking op beheer en onderhoud en realisatie van nieuw groen. Een vijfde van de Nederlanders is betrokken bij een burgerinitiatief. Die betrokkenheid uit zich vooral in het ontvangen van informatie en heel weinig in de uitvoering.

Op basis van de mate van natuurbetrokkenheid zijn vier groepen burgers onderscheiden. De grootste groep, iets meer dan de helft van de burgers, is matig actief betrokken, één op de vijf burgers is weinig of niet betrokken en één op de tien is zeer actief betrokken. De mensen die matig actief betrokken zijn, zijn dit vooral als gebruiker van natuur. Men is nauwelijks actief als beschermer of beslisser. De kleine groep mensen die zeer actief betrokken is, is dit zowel als gebruiker, beschermer en beslisser.

\subsection{Trends in het maatschappelijk draagvlak voor natuur}

In deze paragraaf staan we stil bij de conclusies over de trends in het draagvlak voor natuur in de afgelopen jaren. De draagvlakenquête van 2017 is de vijfde in een reeks die ruim twintig jaar geleden zijn start kende. Eerdere metingen vonden plaats in 1996, 2001, 2006 en 2013. In de loop van de jaren zijn enquêtevragen aangepast, verwijderd of toegevoegd en ook de antwoordcategorieën van diverse vragen zijn niet gelijk gebleven. Dit alles beperkt de mogelijkheid van het vinden van trends over een langere periode. Een groot deel van de bevindingen heeft dan ook betrekking op de beweging in het draagvlak sinds 2006, en voor het onderwerp groene burgerinitiatieven kunnen we niet verder teruggaan dan naar 2013, het jaar dat dit onderwerp is toegevoegd aan de draagvlakenquête.

\section{Belang van natuurbehoud}

De Nederlandse bevolking is doordrongen van het besef om de natuur te beschermen. Door de jaren heen vindt twee op de drie Nederlanders niet dat alle aandacht voor natuur overdreven is, maar nodig. Ook valt op dat door de jaren heen ongeveer de helft van de Nederlanders het terecht vindt dat we ons zorgen maken over de toekomst van de natuur in Nederland. Het hoge maatschappelijke probleembesef omtrent het belang van natuur kent sinds 2001 wel een dalende lijn. In 2017 is deze daling stopgezet en buigt het probleembesef weer om naar het hoge niveau van 2001: een groter aandeel van de Nederlanders vindt het belangrijk dat er veel aandacht is voor natuur en dat de overheid geld uitgeeft aan natuurbehoud.

De dilemma's tussen economie en natuur pakken in vrijwel alle jaren $(2001,2006,2013)$ in het voordeel van natuur uit, met uitzondering van 2013 voor het dilemma over de manier waarop files bestreden moeten worden. De opvattingen over alle dilemma's economie-natuur zijn in de loop der jaren licht veranderd en buigen in 2017 weer richting die van 2006, in het voordeel van natuur; dat geldt voor de dilemma's groen-winkels, rekeningrijden-wegen. Het dilemma woningen-natuur neigt daarentegen ten opzichte van 2013 in 2017 meer ten faveure van woningen.

Het publiek uit in 2017 ten opzichte van 2013 een sterkere wens naar natuur waar de menselijke invloed gering is. Dit zien we met name terug in de drie uitspraken die de meeste bijval van het publiek krijgen. In 2001 wilde 76\% van het publiek liever geen bebouwing in de natuur, dit aandeel zakte naar 68\% (2006) en 61\% (2013), waarna nu weer de grote meerderheid (78\%) blijk geeft van 
een voorkeur voor geen bebouwing. De uitspraak over het afsluiten van sommige gebieden voor publiek krijgt iets meer bijval in 2017 in vergelijking tot 2013. En ook vindt tussen 2006 en 2017 een groeiend aandeel Nederlanders (tot ruim 60\% in 2017) dat de waarde van een natuurgebied toeneemt, als het door mensen met rust wordt gelaten, waarbij het percentage Nederlanders van 2001 (78\%) overigens nog ver weg lijkt. Ook in relatie tot bomen kappen en bijvoederen van dieren is een lichte verschuiving zichtbaar richting de beheervisie van 'handen af van de natuur'.

De Nederlandse bevolking is in 2017 iets minder tevreden over de hoeveelheid natuur in Nederland dan in 2013, maar nog altijd positiever dan in 2006. In 2017 vond 63\% dit (ruim) voldoende, in 2006 was niet meer dan $47 \%$ tevreden over de hoeveelheid natuur in Nederland. Dit patroon zien we ook voor de hoeveelheid natuur in de woonomgeving: in 2017 is $77 \%$ tevreden, dit is een lichte daling ten opzichte van 2013 (80\%), maar nog ruim boven de 67\% van de burgers die in 2006 aangaf tevreden te zijn over de hoeveelheid natuur in de woonomgeving.

Opvallend is dat het belang dat mensen aan het behoud van natuur hechten in 2013 een dip liet zien, terwijl de tevredenheid over de hoeveelheid natuur in 2013 juist groter was dan in eerdere en latere jaren. Het lijkt er dus op dat mensen kritischer zijn over de omvang van natuur (in hun woonomgeving, in Nederland), op het moment dat zij meer belang hechten aan natuurbehoud.

\section{Steun voor natuurbeleid}

Hoe belangrijk vinden mensen de natuur als onderwerp voor overheidsbeleid? Duidelijk is dat door de jaren heen natuur geen prioritair thema is, in de ogen van het publiek. In 2017 is het onderwerp verder gezakt in belang: waar in 2006 en 2013 nog circa één op de vijf mensen dit een prioritair onderwerp vond, is dat in 2017 gezakt naar 14\%. In vergelijking tot 2001 (56\%) oogt de afname enorm. Daarbij moet worden opgemerkt dat het lijstje van onderwerpen in dat jaar grotendeels afweek van latere jaren, wat invloed kan hebben en daarmee de interpretatie van de bevindingen lastig maakt.

Het publiek ziet zowel in 2013 als 2017 de overheid als hoofdverantwoordelijk voor natuur én burgers, bedrijfsleven, natuurorganisaties en landbouwbedrijven als medeverantwoordelijk. Het toekennen van een verantwoordelijke rol van andere actoren dan de overheid lijkt ten opzichte van 2013 te zijn afgenomen.

Ook al vinden mensen onderwerpen als gezondheidszorg, onderwijs, werkgelegenheid en misdaad en terrorisme duidelijk meer belangrijke onderwerpen voor de overheid om op te pakken, toch steunt het publiek onverminderd in alle jaren massaal maatregelen om de natuur te beschermen en verbeteren. Het beschermen van bestaande natuurgebieden vinden burgers door de jaren heen de belangrijkste maatregel. Ook het draagvlak voor de maatregel om biodiversiteit te beschermen is fors: ten opzichte van 2013 is dit gestegen van 85\% naar 91\% in 2017. Opvallend is verder de stijging in het belang van de aanleg en het vergroten van natuurgebieden tussen 2013 en 2017: van 65\% naar 79\% in 2017; daarmee is het draagvlak weer op het niveau van de periode 1996-2006. Ook het gegroeide draagvlak om natuurgebieden met elkaar te verbinden is opvallend: van 56\% in 2006 naar $62 \%$ in 2013 en $68 \%$ in 2017.

\section{Betrokkenheid bij natuur}

\section{Burger als gebruiker}

Door de jaren heen is een patroon zichtbaar dat circa de helft van de bevolking regelmatig tot bijna dagelijks in de natuur komt; omgekeerd komt een bijna even groot deel (bijna) nooit tot hooguit een enkele keer in de natuur: in stadsnatuur ligt dat aandeel wat lager, in natuurgebieden en plattelandsnatuur komt ruim de helft van de Nederlandse burger zelden. Tussen 2013 en 2017 doet zich geen verschil voor in de bezoekfrequentie van het platteland. Tussen 2006, 2013 en 2017 is het parkbezoek wel toegenomen, het bezoek aan natuurgebieden is toegenomen tussen 2006 en 2013, en weer ietwat gedaald tussen 2013 en 2017. 
Circa driekwart van de bevolking gebruikt één of meer informatiebronnen over natuur. Tussen 2006 en 2017 is het internet vaker geraadpleegd, met een piek in 2013 . Tussen 2013 en 2017 zijn minder televisieprogramma's over natuur bekeken, en ook zijn minder tijdschriften gelezen en is het gebruik van webcams afgenomen. Daarentegen is het gebruik van sociale media over natuur toegenomen.

\section{Burger als beschermer}

Zowel in 2006, 2013 als 2017 heeft iets meer dan de helft van de Nederlanders activiteiten voor natuur verricht. Meest genoemd in alle jaren is het plaatsen van nestkastjes, deze activiteit kent overigens wel een daling in 2017 ten opzichte van de eerdere jaren. Dat patroon is ook zichtbaar voor de aanleg van streekeigen beplanting bij de woning. In 2017 hebben daarentegen meer mensen afval in de natuur opgeruimd.

Het percentage burgers dat op de een of andere manier financieel bijdraagt aan natuur is in 2017 afgenomen ten opzichte van eerdere jaren: in 2006, 2013 en 2017 ging het respectievelijk om 50\%, $49 \%$ en $45 \%$ van de bevolking. In de manier warop financieel wordt bijgedragen zijn ook verschuivingen zichtbaar. Tussen 2013 en 2017 hebben minder mensen een natuurvriendelijk product gekocht, terwijl het aandeel mensen dat een bedrag heeft gegeven voor natuurbescherming is toegenomen. Tot slot hebben in deze periode minder mensen meegedaan aan een adoptieactie.

\section{Burger als beslisser}

In grote lijnen doen zich tussen 2013 en 2017 geen verschuivingen voor in de activiteiten die het publiek onderneemt in de besluitvorming rond natuur.

Het aantal mensen dat geen groene burgerinitiatieven kent is tussen 2013 en 2017 afgenomen, van $67 \%$ naar $61 \%$. 


\section{Literatuur}

Bakker, H.C.M. de, en C.S.A. van Koppen (2009). Draagvlakonderzoek in de steigers. Een voorstudie naar indicatoren om maatschappelijk draagvlak voor natuur en landschap te meten. WOt-werkdocument 145. Wageningen: Wettelijke Onderzoekstaken Natuur \& Milieu, Wageningen UR.

Bakker, H.C.M. de, C.S.A. van Koppen en J. Vader (2007). Het groene hart van burgers. Het maatschappelijk draagvlak voor natuur en natuurbeleid. WOt-rapport 47. Wageningen: Wettelijke Onderzoekstaken Natuur \& Milieu, Wageningen UR.

Boedeltje, M. en L. de Graaf (2004). Draagvlak nader bekeken. Een verkenning van het begrip draagvlak binnen interactief beleid op lokaal niveau vanuit een normatief en instrumenteel perspectief. Paper voor het politicologenetmaal. Antwerpen.

Boer, de T.A. en R. Schulting (2002). Zorg(en) voor natuur. Draagvlak voor natuur en natuurbeleid in 2001. Alterra-rapport 453. Wageningen: Alterra, Research Instituut voor de Groene Ruimte.

Boer, de T.A., A.T. de Blaeij, B.H.M Elands, H.C.M. de Bakker, C.S.A. van Koppen en A.E. Buijs (2014). Maatschappelijk draagvlak voor natuur en natuurbeleid in 2013. WOt-rapport 126. Wageningen: Wettelijke Onderzoekstaken Natuur \& Milieu, Wageningen UR.

Bogaert, D.C.M. (2004). Natuurbeleid in Vlaanderen. Natuurontwikkeling en draagvlak als vernieuwingen? Nijmegen: Proefschrift Katholieke Universiteit Nijmegen.

Bosch, F.J.P. van den (2007). Draagvlak voor het Natura 2000-gebiedenbeleid. Onder relevante betrokkenen op regionaal niveau. WOt-werkdocument 55. Wageningen: Wettelijke Onderzoekstaken Natuur \& Milieu, Wageningen UR.

Buijs, A.E. en C.M. Volker (1997). Publiek draagvlak voor natuur en natuurbeleid. Wageningen: DLO-Staring Centrum.

Buijs, A.E., J.F. Coeterier, P. Filius en M.B. Schöne. (1998). Graadmeters sociaal draagvlak en beleving. Werkdocument DLO-Natuurplanbureau-onderzoek 1998/07. Wageningen: DLO-Staring Centrum.

Buijs, A.E., F. Langers, T. Mattijssen en I. Salverda (2012). Draagvlak in de energieke samenleving: van acceptatie naar betrokkenheid en legitimatie. Alterra rapport 2362. Alterra, Wageningen UR en Leerstoelgroep Bos en Natuurbeheer, Wageningen University.

Carabain, C., C. Hoeks, E. Boonstoppel \& L. Hogeling (2013). Nederlanders \& Draagvlak voor Ontwikkelingssamenwerking. Een verdiepende studie. NCDO Onderzoeksreeks 16. Nederlandse kennis- en adviescentrum voor burgerschap en internationale samenwerking, Amsterdam.

CBS, PBL, RIVM, WUR (2017). Ledenaantal particuliere natuur- en milieuorganisaties, 1989 - 2016 (indicator 1281, versie 14 , 3 augustus 2017 ). www.clo.nl. Centraal Bureau voor de Statistiek (CBS), Den Haag; PBL Planbureau voor de Leefomgeving, Den Haag; RIVM Rijksinstituut voor Volksgezondheid en Milieu, Bilthoven; en Wageningen University and Research, Wageningen.

Elands B.H.M. en C.S.A. van Koppen (2007). Indicators for the 'Convention on Biodiversity 2010'. Public awareness and participation. WOt-werkdocument 53.12. Wageningen: Wettelijke Onderzoekstaken Natuur \& Milieu, Wageningen UR.

Elands B.H.M. en E. Turnhout (red.) (2009). Burgers, beleid en natuur: tussen draagvlak en betrokkenheid. WOt-studies nr. 9. Wageningen: Wettelijke Onderzoekstaken Natuur \& Milieu, Wageningen UR.

European Union (2015). Special Eurobarometer 436 "Attitudes of Europeans towards biodiversity." European Union, Brussels.

Goldenbeld, Ch. (2002). Publiek draagvlak voor verkeersveiligheid en veiligheidsmaatregelen. Leidschendam: Stichting Wetenschappelijk Onderzoek Verkeersveiligheid SWOV. 



\section{Verantwoording}

Dit project werd begeleid door Hendrien Bredenoord (Planbureau voor de Leefomgeving) en Martin Goossen (Wageningen Environmental Research). De analyse van de ontwikkelingen in de tijd werd afgestemd met Arjen Buijs en Birgit Elands (beiden Wageningen University) van het project Historisch Draagvlak.

De auteurs bedanken allen voor hun bijdrage aan het tot stand komen van deze rapportage. 


\section{Bijlage 1 Veranderingen in de vragenlijst 2017 - 2013}

Vragen 2017

Aanpassingen t.o.v. 2013

Hoofdindicator 1. Belang van natuurbehoud

Probleembesef

De volgende uitspraken gaan over het belang van de

Nederlandse natuur voor $u$. Wilt u bij elke uitspraak aangeven

of $u$ het hiermee eens bent of niet?

1. Al die aandacht voor natuur is overdreven

2. We maken ons te veel zorgen over de toekomst van de natuur in Nederland

3. De overheid geeft te weinig geld uit aan natuurbehoud

4. De natuur mag geen belemmering zijn voor economische vooruitgang

1. Helemaal niet mee eens

2. Niet mee eens

3. Niet mee eens / niet mee oneens

4. Mee eens

5. Helemaal mee eens

0 . Weet ik niet

Belang natuur: prioritering natuur vs. economie
Natuur is vaak onderwerp van maatschappelijke discussie. Naast de behoefte aan natuur speelt ook de behoefte aan woningen en wegen. Welke kant zou u kiezen?

1. Meer groen in mijn gemeente $<>$ meer winkels in mijn gemeente

2. Meer parkeerplaatsen in mijn woonwijk $<>$ meer speelveldjes en bomen in mijn woonwijk

3. Files bestrijden door rekeningrijden $<>$ files bestrijden door extra wegen

4. Meer woningen in mijn gemeente $<>$ aanleg nieuwe natuur in mijn gemeente

5. Kleinschalige landbouw met duurdere producten $<>$ grootschalige landbouw met goedkopere producten
- Uitspraken over discoursen verwijderd, omdat ze niet passen binnen vraag probleembesef

- Antwoordcategorie aangepast: rijksoverheid is overheid geworden

schaal 1-4 --> economie-natuur

en

Cognitief
Natuur in Nederland is een breed begrip. Hieronder volgt een aantal voorbeelden van wat er in Nederland onder natuur kan worden verstaan. Kunt u per element aangeven in hoeverre $u$ dit als echte natuur beschouwt (11 items).

(ik vind... moerassen, maisvelden, ..etc.

Helemalgeen natuur..... helemalechte natuur)
Normatief
De volgende uitspraken gaan over hoe u met de natuur wilt omgaan. Wilt $u$ bij elke uitspraak aangeven of $u$ het hiermee eens bent of niet ( 11 items)

1. Dode bomen in het bos moeten worden opgeruimd

2. Hoe langer een natuurgebied door mensen met rust is gelaten, des te groter de waarde van het gebied

3. In de natuur kom ik liever geen bebouwing tegen*

4. Om de natuur te beschermen moeten sommige gebieden worden afgesloten voor bezoekers

5. Bermen langs de weg moeten netjes gemaaid worden

6. Hoogspanningsmasten en windmolens maken natuurgebieden minder waardevol*

7. Het in koude winters bijvoederen van wilde dieren vind ik niet nodig*
Vraag wordt niet herhaald in 2017, omdat het antwoord op deze vraag al een aantal metingen stabiel is (mensen hebben een breed natuurbeeld) en de verwachting is dat ook de volgende meting zo zal zijn.

Identiek

Vragen met * zijn ook gesteld in 2006 en 2013 
8. Bomen en struiken in natuurgebieden mogen worden gekapt om het aantal verschillende soorten planten en dieren te vergroten*

9. Om een gebied als natuur te bestempelen moet het een behoorlijke omvang hebben*

10. Als dieren, zoals herten, wilde zwijnen of ganzen, overlast veroorzaken is jacht geoorloofd

11. Ik vind het belangrijk dat we de natuur ook gebruiken voor houtproductie

1. Helemaal niet mee eens

2. Niet mee eens

3. Niet mee eens / niet mee oneens

4. Mee eens

5. Helemaal mee eens

0 . Weet ik niet

Waardering natuur en groen

\section{Wat vindt $u$ van de hoeveelheid natuur in geheel Nederland?}
1. Te weinig
2. Weinig
3. Voldoende
4. Ruim voldoende
5: Te veel
0 . Weet ik niet

\section{Wat vindt $u$ van de hoeveelheid natuur en groen in uw eigen woonomgeving?}
1. Te weinig
2. Weinig
3. Voldoende
4. Ruim voldoende
5: Te veel
0 . Weet ik niet

Belang natuur

\section{Mensen vinden natuur om verschillende redenen belangrijk. Kunt $u$ aangeven in hoeverre $u$ onderstaande redenen belangrijk vindt?}

1. De natuur is belangrijk voor recreatie (bijv. om in te wandelen en te fietsen)

2. De natuur is belangrijk om van te kunnen genieten

3. De natuur is belangrijk van zichzelf

4. De natuur is belangrijk voor de gezondheid (bijv. schone lucht)

5. Wij zijn het aan onze kinderen verplicht om de natuur te beschermen

6. De natuur is belangrijk omdat er geld mee verdiend kan worden (bijv. houtproductie)

7. De natuur is belangrijk omdat het ons herinnert aan de oorsprong van het leven

8. De natuur is belangrijk voor de wetenschap (bijv. als bron voor medicijnen)

9. De natuur is belangrijk voor de landbouw (bijv. bestuiven van gewassen door bijen)

1. Helemaal niet belangrijk

2. Niet belangrijk

3. Niet belangrijk / niet onbelangrijk

4. Belangrijk

5. Zeer belangrijk

0. Weet ik niet
Identiek 
Hoofdindicator 2. Steun voor natuurbeleid

\begin{tabular}{|c|c|c|}
\hline $\begin{array}{l}\text { Steun voor } \\
\text { natuurbeleid irt } \\
\text { andere } \\
\text { beleidsthema's }\end{array}$ & $\begin{array}{l}\text { De overheid houdt zich met veel onderwerpen bezig. Welke } 4 \\
\text { onderwerpen zouden volgens u de grootste prioriteit van de } \\
\text { overheid moeten zijn? } \\
\text { 1. Gezondheidszorg } \\
\text { 2. Misdaad en terrorisme } \\
\text { 3. Immigratie en integratie } \\
\text { 4. Milieu- en klimaat } \\
\text { 5. Sociale zekerheid } \\
\text { 6. Natuur } \\
\text { 7. Onderwijs } \\
\text { 8. Werkgelegenheid } \\
\text { 9. Normen en waarden } \\
\text { 10. Ouderen } \\
\text { 0. Geen van deze }\end{array}$ & $\begin{array}{l}\text { Vraag en onderwerpen } \\
\text { aangepast } \\
\text { - Rijksoverheid wordt } \\
\text { overheid } \\
\text { - Allochtonen wordt } \\
\text { immigratie en integratie } \\
\text { - Milieu- en luchtvervuiling } \\
\text { wordt Milieu- en klimaat }\end{array}$ \\
\hline $\begin{array}{l}\text { Verantwoordelijke } \\
\text { actoren }\end{array}$ & $\begin{array}{l}\text { In hoeverre zouden de volgende partijen verantwoordelijkheid } \\
\text { voor natuur moeten dragen? Wilt u dit voor elke partij } \\
\text { aangeven en per type natuur? } \\
\text { - Overheid } \\
\text { - Landbouwbedrijven } \\
\text { - Natuurorganisaties } \\
\text { - Overig bedrijfsleven } \\
\text { - Burgers } \\
\text { - Natuur in natuurgebieden } \\
\text { - Natuur op het platteland } \\
\text { - Natuur in de stad } \\
\text { 1. Hoofdverantwoordelijk } \\
\text { 2. Medeverantwoordelijk } \\
\text { 3. Niet verantwoordelijk } \\
\text { 0. Weet ik niet }\end{array}$ & $\begin{array}{l}\text { Vraag aangepast: wordt nu } \\
\text { gesteld voor } 3 \text { typen natuur } \\
\text { i.p.v. natuur in z'n } \\
\text { algemeenheid } \\
\text { Naamgeving partijen } \\
\text { aangepast: } \\
\text { - Landbouwbedrijven i.p.v. } \\
\text { landbouw } \\
\text { - Natuurorganisaties i.p.v. } \\
\text { Natuurbeschermingsorganis } \\
\text { aties } \\
\text { - Overig bedrijfsleven i.p.v. } \\
\text { toeristische ondernemers } \\
\text { projectontwikkelaars }\end{array}$ \\
\hline $\begin{array}{l}\text { Waardering } \\
\text { beleidsmaatregelen }\end{array}$ & $\begin{array}{l}\text { Er zijn verschillende maatregelen om de natuur in Nederland te } \\
\text { beschermen en te verbeteren. Kunt u per matregel in } \\
\text { hoeverre u dit belangrijk vindt? } \\
\text { 1. Beschermen van bestaande natuurgebieden } \\
\text { 2. Aanleg en/of vergroten van natuurgebieden } \\
\text { 3. Natuurgebieden met elkaar verbinden } \\
\text { 4. Beschermen van zeldzame planten, dieren en bijzondere gebieden } \\
\text { 5. Het beheren en onderhouden van natuurgebieden } \\
\text { 6. Beschermen van natuur op het platteland } \\
\text { 7. Meer paden, bankjes, informatiepanelen en dergelijke } \\
\text { 8. Meer natuur in de stad (bv. parken en plantsoenen) } \\
\text { 9. Meer natuur op het platteland (bv. agrarische natuur) } \\
\text { 10. Meer natuureducatie op scholen } \\
\text { 11. Burgers betrekken bij het beschermen en verbeteren van de } \\
\text { 12. Bedrijven betrekken bij het beschermen en verbeteren van de } \\
\text { Wat vindt u de } 3 \text { belangrijkste maatregelen? } \\
\text { 4. } \text { neer belangrijk } \\
\text { 1. Helemaal niet belangrijk } \\
\text { 3. Niet belangrijk }\end{array}$ & $\begin{array}{l}\text { Maatregel aangepast: } \\
\text { - Aanleg en/of vergroten van } \\
\text { natuurgebieden i.p.v. } \\
\text { Aanleg nieuwe } \\
\text { natuurgebieden } \\
\text { Nieuwe maatregelen: } \\
\text { - Het beheren en } \\
\text { onderhouden van } \\
\text { natuurgebieden } \\
\text { - Beschermen van natuur op } \\
\text { het platteland } \\
\text { - Burgers betrekken bij het } \\
\text { beschermen en verbeteren } \\
\text { van de natuur } \\
\text { - Bedrijven betrekken bij het } \\
\text { beschermen en verbeteren } \\
\text { van de natuur }\end{array}$ \\
\hline
\end{tabular}




\begin{tabular}{|l|l|l|}
\hline & $\begin{array}{l}\text { Voor de aanleg of het vergroten van natuurgebieden is vaak } \\
\text { grond nodig van particulieren. Als de grondeigenaar hier niet } \\
\text { aan mee wil werken, kan de overheid overgaan tot onteigening } \\
\text { om de natuur te realiseren. Wat is uw mening over het inzetten } \\
\text { van het onteigeningsinstrument voor de aanleg of het } \\
\text { vergroten van natuurgebieden? } \\
\text { 1. Helemaal niet mee eens } \\
\begin{array}{l}\text { 2. Niet mee eens } \\
\text { 3. Niet mee eens / niet mee oneens } \\
\text { 4. Mee eens } \\
\text { 5. Helemaal mee eens } \\
0 . \text { Weet ik niet }\end{array}\end{array}$ \\
\hline
\end{tabular}

Vragen 2017

Aanpassingen t.o.v. 2013

\begin{tabular}{|c|c|c|}
\hline $\begin{array}{l}\text { Intentie } \\
\text { betrokkenheid }\end{array}$ & $\begin{array}{l}\text { De overheid wil burgers graag betrekken bij het beschermen } \\
\text { en verbeteren van de natuur. Welke mogelijkheden spreken u } \\
\text { aan (1-4 naar vraag Xa) } \\
\text { 1. Geïnformeerd worden over wat ik kan doen voor de natuur } \\
\text { 2. Meedenken met de gemeente, provincie of natuurorganisatie(s) } \\
\text { over hun plannen voor natuur } \\
\text { 3. Vrijwilligerswerk doen voor een lokale, provinciale of landelijke } \\
\text { natuurorganisatie. } \\
\text { 4elf met bewoners buurtgroen of natuur verbeteren of } \\
\text { 5. Ik wil niet betrokken zijn (naar vraag } \mathrm{Xb} \text { ) }\end{array}$ & Nieuwe vraag \\
\hline \multirow[t]{2}{*}{$\begin{array}{l}\text { Motieven voor } \\
\text { betrokkenheid }\end{array}$} & $\begin{array}{l}\text { Wat zijn uw belangrijkste motieven om betrokken te willen zijn } \\
\text { bij de natuur? ( } m a x .3 \text { ) } \\
\text { 1. Betrokkenheid bij mijn woonomgeving } \\
\text { 2. Leuk, interessant werk } \\
\text { 3. Andere mensen ontmoeten, vrienden maken } \\
\text { 4. Actief en gezond blijven } \\
\text { 5. Nieuwe kennis en vaardigheden opdoen } \\
\text { 6. Nuttige contacten opdoen } \\
\text { 7. Zinvolle tijdsbesteding } \\
\text { 8. Verbreden van levenservaring } \\
\text { 9. Iets voor de maatschappij doen } \\
\text { 10. Morele, religieuze en/of politieke principes } \\
\text { 11. Het geeft sociale erkenning } \\
\text { 12. Anders, namelijk }\end{array}$ & Nieuwe vraag \\
\hline & $\begin{array}{l}\text { Wat weerhoudt u er van om betrokken te willen zijn bij de } \\
\text { natuur? } \\
\text { 1. Niet belangrijk genoeg, natuur heeft geen prioriteit } \\
\text { 2. Geen tijd } \\
\text { 3. Ander vrijwilligerswerk } \\
\text { 4. Onbekend met de mogelijkheden om iets te doen } \\
\text { 5. Anders, namelijk }\end{array}$ & Nieuwe vraag \\
\hline
\end{tabular}

Burger als

beschermer actief: activiteiten m.b.t. beheer van natuur
Welke van de volgende activiteiten voor de natuur heeft $u$ de afgelopen 12 maanden wel eens ondernomen? (10 items)

1. Onderhoud van natuur of landschap (bomen snoeien \& knotten, bermbeheer, poelen schonen, houtwallen afzetten etc.)

2. Aanleg van streekeigen beplanting bij mijn huis

3. Plaatsen van nestkastjes, voederplankjes bij mijn huis

4. Weidevogelbescherming

5. Inventarisatie van dier- of plantsoorten (bijv. tuinvogeltelling, waarneming.nl)

6. Geven van natuureducatie, lezingen en rondleidingen

7. Sociale activiteiten in de natuur organiseren (scouting, zorg, reizen etc)

8. Afval van anderen in de natuur opruimen

9. Anders, namelijk

0. Geen van deze
Vraag aangepast: 'voor de natuur' toegevoegd

Antwoordcategorieën aangepast:

Bij Inventarisatie van dier- of plantsoorten, is toegevoegd: '(bijv. tuinvogeltelling, waarneming.nl)' 'Natuurstudie' is uit de vraag verwijderd 


\begin{tabular}{|c|c|c|}
\hline $\begin{array}{l}\text { Burger als } \\
\text { beschermer passief: } \\
\text { financiële bijdrage } \\
\text { leveren }\end{array}$ & $\begin{array}{l}\text { Mensen kunnen financieel bijdragen aan natuur. Heeft u in de } \\
\text { afgelopen } \mathbf{1 2} \text { maanden wel eens het volgende gedaan? } \\
\text { 1. Een bedrag gegeven voor natuurbescherming } \\
\text { 2. Groen belegd } \\
\text { 3. Producten gekocht die rekening houden met natuur (eco- } \\
\text { keurmerk, FSC-hout, duurzaam katoen, weidevogelmelk etc.) } \\
\text { 4. Aan een adoptieactie meegedaan (kip, kalf, koe, akkerrand, } \\
\text { boom, etc.) } \\
\text { 5. Een certificaat voor bosaanplant aangekocht ter compensatie van } \\
\text { de uitstoot van broeikasgassen door vliegreizen (via Green Seat } \\
\text { etc.) } \\
\text { 6. Anders, namelijk }\end{array}$ & $\begin{array}{l}\text { Antwoordcategorie aangepast: } \\
\text { 'Extra' verwijderd (extra } \\
\text { bedrag) }\end{array}$ \\
\hline $\begin{array}{l}\text { Burger als } \\
\text { beschermer passief: } \\
\text { lidmaatschap } \\
\text { natuurorganisatie }\end{array}$ & $\begin{array}{l}\text { Bent u lid van een natuurorganisatie (bijv. Natuurmonumenten, } \\
\text { Provinciaal Landschap)? } \\
0 . \quad \text { Nee } \\
\text { 1. Ja, namelijk Natuurmonumenten, Provinciaal Landschap, } \\
\quad \text { Wereldnatuurfonds, Overig }\end{array}$ & $\begin{array}{l}\text { Antwoordcategorie uitgebreid: } \\
\text { aangeven van welke } \\
\text { natuurorganisatie men lid is. }\end{array}$ \\
\hline $\begin{array}{l}\text { Burger als gebruiker } \\
\text { actief: gebruik van } \\
\text { natuur }\end{array}$ & $\begin{array}{l}\text { Hoe vaak bracht u in de afgelopen } 12 \text { maanden uw vrije tijd } \\
\text { door op de volgende plekken? } \\
\text { 1. Parken en groen in de stad } \\
\text { 2. Platteland } \\
\text { 3. Natuurgebied (bos, heide, duinen, meren en plassen, etc.) } \\
\text { 1. (Bijna) nooit } \\
\text { 2. Een enkele keer } \\
\text { 3. Regelmatig (maandelijks) } \\
\text { 4. Vaak (wekelijks) } \\
\text { 5. Zeer vaak (bijna dagelijks) }\end{array}$ & $\begin{array}{l}\text { Antwoordcategorieën } \\
\text { aangepast: } \\
\text { Regelmatig: (maandelijks) } \\
\text { toegevoegd } \\
\text { Vaak: (wekelijks) toegevoegd } \\
\text { Zeer vaak (bijna dagelijks) }\end{array}$ \\
\hline $\begin{array}{l}\text { Burger als gebruiker } \\
\text { passief: informatie } \\
\text { over natuur } \\
\text { gebruiken }\end{array}$ & $\begin{array}{l}\text { Er zijn verschillende mogelijkheden om iets over natuur te } \\
\text { weten te komen. Van welke mogelijkheden maakte u de } \\
\text { afgelopen } 12 \text { maanden gebruik? U kunt meerdere antwoorden } \\
\text { geven } \\
\text { 1. Televisieprogramma of film over natuur bekeken } \\
\text { 2. Tijdschrift/boek/artikel over natuur gelezen } \\
\text { 3. Internet over natuur geraadpleegd } \\
\text { 4. Webcam(s) over natuur bekeken } \\
\text { 5. Social media (twitter, facebook) over natuur gevolgd } \\
\text { 6. Apps over natuur } \\
\text { 7. Anders, namelijk } \\
\text { 0. Geen van deze }\end{array}$ & $\begin{array}{l}\text { Antwoordcategorie } \\
\text { toegevoegd: 'Apps over } \\
\text { natuur' }\end{array}$ \\
\hline $\begin{array}{l}\text { Burger als beslisser } \\
\text { actief: } \\
\text { activiteiten m.b.t. } \\
\text { beslissingen over } \\
\text { natuur (m.u.z. van } \\
\text { handtekening zetten } \\
\text { en stemmen) } \\
\text { Burger als beslisser } \\
\text { passief: } \\
\text { activiteiten m.b.t. } \\
\text { beslissingen over } \\
\text { natuur: } \\
\text { van handtekening } \\
\text { zetten en groen } \\
\text { stemmen }\end{array}$ & $\begin{array}{l}\text { Welke van de volgende activiteiten heeft u de afgelopen } \mathbf{1 2} \\
\text { maanden wel eens ondernomen? } \\
\text { 1. Buurtoverleg over groenbeheer bijgewoond } \\
\text { 2. Actie gevoerd voor meer natuur of behoud van natuur } \\
\text { 3. Naar inspraak- of informatieavond over natuur geweest } \\
\text { 4. Brieven of opiniestukken geschreven over de natuur } \\
\text { 5. Handtekening gezet voor de natuur } \\
\text { 6. Protestmail gestuurd over de natuur } \\
\text { 7. In mijn stemkeuze het onderwerp natuur mee laten wegen } \\
\text { 8. Anders, namelijk } \\
\text { 0. Geen van deze }\end{array}$ & $\begin{array}{l}\text { Antwoordcategorie } \\
\text { toegevoegd: 'In mijn } \\
\text { stemkeuze het onderwerp } \\
\text { natuur mee laten wegen' }\end{array}$ \\
\hline & $\begin{array}{l}\text { Kent u projecten op het gebied van natuur en landschap in uw } \\
\text { woonplaats waarbij burgers het initiatief hebben genomen om } \\
\text { het groen/natuur te verbeteren of te beschermen? } \\
\text { 1. Ja (naar vraag } \mathrm{x} \text { ) } \\
\text { 2. Nee (einde vragenlijst) } \\
\text { 3. Weet ik niet (einde vragenlijst) }\end{array}$ & $\begin{array}{l}\text { Vraag aangepast: om het } \\
\text { groen/natuur te verbeteren of } \\
\text { te beschermen is toegevoegd }\end{array}$ \\
\hline
\end{tabular}




\begin{tabular}{|c|c|c|}
\hline & $\begin{array}{l}\text { Zo ja, om wat voor soort initiatief gaat het? } \\
\text { 1. Het initiatief heeft betrekking op beheer en onderhoud (opruimen } \\
\text { van afval, wilgen knotten, sloten schonen) } \\
\text { 2. Het initiatief heeft betrekking op realisatie van nieuw groen (bijv. } \\
\text { planten van bomen, inrichten van tuinen, bouwen vogelkijkhut) } \\
\text { 3. Het initiatief heeft betrekking op actievoeren (bijv. protestacties, } \\
\text { inzamelen handtekeningen) } \\
\text { 4. Het initiatief heeft betrekking op educatieve activiteiten (bijv. } \\
\text { 5. Ancursies, lezingen) }\end{array}$ & $\begin{array}{l}\text { Vraag aangepast: Zo ja, om } \\
\text { wat voor soort initiatief gaat } \\
\text { het? (i.p.v. wilt u het initiatief } \\
\text { omschrijven) }\end{array}$ \\
\hline $\begin{array}{l}\text { Burger als beslisser } \\
\text { actief: } \\
\text { ik ben (één van de) } \\
\text { initiatiefnemer(s) } \\
\text { Burgers als } \\
\text { beschermer actief: } \\
\text { ik werk mee aan de } \\
\text { uitvoering van het } \\
\text { initiatief }\end{array}$ & $\begin{array}{l}\text { Hoe bent u betrokken bij een dergelijk initiatief? } \\
\text { 1. Ik ben (één van de) initiatiefnemer(s) } \\
\text { 2. Ik ontvang informatie over het initiatief } \\
\text { 3. Ik werk mee aan de uitvoering van het initiatief } \\
0 . \quad \text { Geen van deze }\end{array}$ & $\begin{array}{l}\text { Vraag aangepast: Hoe bent u } \\
\text { betrokken bij een dergelijk } \\
\text { initiatief ? (i.p.v. bent u } \\
\text { betrokken bij een dergelijk } \\
\text { initiatief). Deze vraag is in } \\
2013 \text { aan alle respondenten } \\
\text { voorgelegd en in } 2017 \text { alleen } \\
\text { aan respondenten die } \\
\text { aangegeven hebben een } \\
\text { initiatief te kennen. } \\
\text { Antwoordcategorie 'Ik denk } \\
\text { mee over het initiatief' is } \\
\text { verwijderd, omdat het } \\
\text { vermoeden bestond dat dit } \\
\text { door respondenten te } \\
\text { makkelijk wordt ingevuld. } \\
\text { Hierdoor werd de groep } \\
\text { mensen die gerekend werden } \\
\text { tot actieve beslissers } \\
\text { oneigenlijk te groot. }\end{array}$ \\
\hline
\end{tabular}




\section{Bijlage 2 Vragenlijst Draagvlak voor natuur en natuurbeleid 2017}

Het Planbureau voor de Leefomgeving ( $P B L$ ) wil graag uw mening over de natuur en het natuurbeleid in Nederland weten. Daarom houdt het PBL elke vijf jaar een enquête onder de bevolking. Wij horen graag uw mening over een aantal zaken. Het is hierbij niet belangrijk of u veel van natuur weet of dat $u$ er vaak komt.

Natuur wordt in deze vragenlijst breed opgevat: het omvat natuurgebieden, natuur op het platteland, en natuur en groen in de stad.

Per vraag is 1 antwoord mogelijk tenzij anders vermeld

1. De overheid houdt zich met veel onderwerpen bezig. Welke 4 onderwerpen zouden volgens u de grootste prioriteit van de overheid moeten zijn?

1. Gezondheidszorg

2. Misdaad en terrorisme

3. Immigratie en integratie

4. Milieu- en klimaat

5. Sociale zekerheid

6. Natuur

7. Onderwijs

8. Werkgelegenheid

9. Normen en waarden

10. Ouderen

0 . Geen van deze

2. Wat vindt $u$ van de hoeveelheid natuur in geheel Nederland?

1. Te weinig

2. Weinig

3. Voldoende

4. Ruim voldoende

5. Te veel

0 . Weet ik niet

3. Wat vindt u van de hoeveelheid natuur en groen in uw eigen woonomgeving?

1. Te weinig

2. Weinig

3. Voldoende

4. Ruim voldoende

5. Te veel

0 . Weet ik niet

4. Mensen vinden natuur om verschillende redenen belangrijk. Kunt $u$ aangeven in hoeverre $u$ onderstaande redenen belangrijk vindt?

1. De natuur is belangrijk voor recreatie (bijv. om in te wandelen en te fietsen)

2. De natuur is belangrijk om van te kunnen genieten

3. De natuur is belangrijk van zichzelf

4. De natuur is belangrijk voor de gezondheid (bijv. schone lucht)

5. Wij zijn het aan onze kinderen verplicht om de natuur te beschermen

6. De natuur is belangrijk omdat er geld mee verdiend kan worden (bijv. houtproductie)

7. De natuur is belangrijk omdat het ons herinnert aan de oorsprong van het leven

8. De natuur is belangrijk voor de wetenschap (bijv. als bron voor medicijnen)

9. De natuur is belangrijk voor de landbouw (bijv. bestuiven van gewassen door bijen) 
1. Helemaal niet belangrijk

2. Niet belangrijk

3. Niet belangrijk / niet onbelangrijk

4. Belangrijk

5. Zeer belangrijk

2. Weet ik niet

4a. Kunt u aangeven welke drie van de bovenstaande redenen $u$ het belangrijkst vindt?

$U$ dient bij deze vraag exact drie antwoorden te kiezen.

5. Hoe vaak bracht $u$ in de afgelopen 12 maanden uw vrije tijd door op de volgende plekken?

1. Parken en groen in de stad

2. Platteland

3. Natuurgebied (bos, heide, duinen, meren en plassen, etc.)

1. (Bijna) nooit

2. Een enkele keer

3. Regelmatig (maandelijks)

4. Vaak (wekelijks)

5. Zeer vaak (bijna dagelijks)

6. Er zijn verschillende mogelijkheden om iets over natuur te weten te komen. Van welke mogelijkheden maakte u de afgelopen 12 maanden gebruik? Er zijn meerdere antwoorden mogelijk.

1. Televisieprogramma of film over natuur bekeken

2. Tijdschrift/boek/artikel over natuur gelezen

3. Internet over natuur geraadpleegd

4. Webcam(s) over natuur bekeken

5. Social media (twitter, facebook) over natuur gevolgd

6. Apps over natuur gebruikt

7. Anders, namelijk

0. Geen van deze

7. Bent u lid van een natuurorganisatie? Er zijn meerdere antwoorden mogelijk.

1. Nee

2. Ja, van Natuurmonumenten

3. Ja, van Provinciale Landschappen

4. Ja, van het Wereldnatuurfonds

5. Ja, van Greenpeace

6. Ja, van een andere organisatie, namelijk:

8. Mensen kunnen financieel bijdragen aan natuur. Heeft $u$ in de afgelopen 12 maanden wel eens het volgende gedaan? Er zijn meerdere antwoorden mogelijk.

1. Een bedrag gegeven voor natuurbescherming

2. Groen belegd

3. Producten gekocht die rekening houden met natuur (eco-keurmerk, FSC-hout, duurzaam katoen, weidevogelmelk etc.)

4. Aan een adoptieactie meegedaan (kip, kalf, koe, akkerrand, boom, etc.)

5. Een certificaat voor bosaanplant aangekocht ter compensatie van de uitstoot van broeikasgassen door vliegreizen (via Green Seat etc.)

6. Anders, namelijk

0. Geen van deze

9. Er zijn verschillende maatregelen om de natuur in Nederland te beschermen en te verbeteren. Kunt u per maatregel aangeven in hoeverre u dit belangrijk vindt?

1. Beschermen van bestaande natuurgebieden

2. Aanleg en/of vergroten van natuurgebieden

3. Natuurgebieden met elkaar verbinden 
4. Beschermen van zeldzame planten, dieren en bijzondere gebieden

5. Het beheren en onderhouden van natuurgebieden

6. Beschermen van natuur op het platteland

7. Meer paden, bankjes, informatiepanelen en dergelijke

8. Meer natuur in de stad (bijv. parken en plantsoenen)

9. Meer natuur op het platteland (bijv. agrarische natuur)

10. Meer natuureducatie op scholen

11. Burgers betrekken bij het beschermen en verbeteren van de natuur

12. Bedrijven betrekken bij het beschermen en verbeteren van de natuur

1. Helemaal niet belangrijk

2. Niet belangrijk

3. Niet belangrijk / niet onbelangrijk

4. Belangrijk

5. Zeer belangrijk

0 . Weet ik niet

9a. Kunt u aangeven welke drie van de bovenstaande maatregelen $\mathbf{u}$ het belangrijkst vindt? $U$ dient bij deze vraag exact drie antwoorden te kiezen.

10. Voor de aanleg of het vergroten van natuurgebieden is vaak grond nodig van particulieren. Als de grondeigenaar (bijv. agrariër) hier niet aan mee wil werken, kan de overheid overgaan tot onteigening ${ }^{7}$ om de natuur te realiseren. Wat is uw mening over het inzetten van het onteigeningsinstrument voor de aanleg of het vergroten van natuurgebieden?

1. Helemaal niet mee eens

2. Niet mee eens

3. Niet mee eens / niet mee oneens

4. Mee eens

5. Helemaal mee eens

0 . Weet ik niet

11. Natuur is vaak onderwerp van maatschappelijke discussie. Hieronder staat een aantal discussies. Welke kant zou u kiezen? (schaal 1-4 --> economie-natuur)

1. Meer groen in mijn gemeente $<>$ meer winkels in mijn gemeente

2. Meer parkeerplaatsen in mijn woonwijk $<>$ meer speelveldjes en bomen in mijn woonwijk

3. Files bestrijden door rekeningrijden $<>$ files bestrijden door extra wegen

4. Meer woningen in mijn gemeente $<>$ aanleg nieuwe natuur in mijn gemeente

5. Kleinschalige landbouw met duurdere producten $<>$ grootschalige landbouw met goedkopere producten

12. De volgende uitspraken gaan over het belang van de Nederlandse natuur voor $u$. Wilt $u$ bij elke uitspraak aangeven of $u$ het hiermee eens bent of niet?

1. Al die aandacht voor natuur is overdreven

2. We maken ons te veel zorgen over de toekomst van de natuur in Nederland

3. De overheid geeft te weinig geld uit aan natuurbehoud

4. De natuur mag geen belemmering zijn voor economische vooruitgang

1. Helemaal niet mee eens

2. Niet mee eens

3. Niet mee eens / niet mee oneens

4. Mee eens

5. Helemaal mee eens

0 . Weet ik niet

\footnotetext{
7 Bij deze vraag is een infobutton geplaatst met uitleg van de term onteigening: Onteigening houdt in dat eigendom verplicht wordt verkocht aan de overheid
} 
13. De volgende uitspraken gaan over hoe u met de natuur wilt omgaan. Wilt u bij elke uitspraak aangeven of $u$ het hiermee eens bent of niet?

1. Dode bomen in het bos moeten worden opgeruimd

2. Hoe langer een natuurgebied door mensen met rust is gelaten, des te groter de waarde van het gebied

3. In de natuur kom ik liever geen bebouwing tegen

4. Om de natuur te beschermen moeten sommige gebieden worden afgesloten voor bezoekers

5. Bermen langs de weg moeten netjes gemaaid worden

6. Hoogspanningsmasten en windmolens maken natuurgebieden minder waardevol

7. Het in koude winters bijvoederen van wilde dieren vind ik niet nodig

8. Bomen en struiken in natuurgebieden mogen worden gekapt om het aantal verschillende soorten planten en dieren te vergroten

9. Om een gebied als natuur te bestempelen moet het een behoorlijke omvang hebben

10. Als dieren, zoals herten, wilde zwijnen of ganzen, overlast veroorzaken is jacht geoorloofd

11. Ik vind het belangrijk dat we de natuur ook gebruiken voor houtproductie

1. Helemaal niet mee eens

2. Niet mee eens

3. Niet mee eens / niet mee oneens

4. Mee eens

5. Helemaal mee eens

0 . Weet ik niet

14. In hoeverre zouden de volgende partijen verantwoordelijkheid voor natuur moeten dragen? Wilt u dit voor elke partij aangeven en per type natuur?

1. Natuur in natuurgebieden

2. Natuur op het platteland

3. Natuur in de stad

1. Overheid

2. Landbouwbedrijven

3. Natuurorganisaties

4. Overig bedrijfsleven

5. Burgers

1. Hoofdverantwoordelijk

2. Medeverantwoordelijk

3. Niet verantwoordelijk

0 . Weet ik niet

15. De overheid wil burgers graag betrekken bij het beschermen en verbeteren van de natuur. Welke mogelijkheden spreken u aan? Er zijn meerdere antwoorden mogelijk.

1. Geïnformeerd worden over wat ik kan doen voor de natuur (naar vraag 15a)

2. Meedenken met de gemeente, provincie of natuurorganisatie(s) over hun plannen voor natuur (naar vraag 15a)

3. Vrijwilligerswerk doen voor een lokale, provinciale of landelijke natuurorganisatie (naar vraag 15a)

4. Zelf met bewoners buurtgroen of natuur verbeteren of onderhouden (naar vraag 15a)

5. Ik wil niet betrokken zijn (naar vraag 15b)

15a. Wat zijn uw belangrijkste motieven om betrokken te willen zijn bij de natuur? Er zijn meerdere antwoorden mogelijk.

1. Betrokkenheid bij mijn woonomgeving

2. Leuk, interessant werk

3. Andere mensen ontmoeten, vrienden maken

4. Actief en gezond blijven

5. Nieuwe kennis en vaardigheden opdoen

6. Nuttige contacten opdoen

7. Zinvolle tijdsbesteding

8. Verbreden van levenservaring 
9. Iets voor de maatschappij doen

10. Morele, religieuze en/of politieke principes

11. Het geeft sociale erkenning

12. Anders, namelijk

15b. Wat weerhoudt u er van om betrokken te willen zijn bij de natuur? Er zijn meerdere antwoorden mogelijk.

1. Niet belangrijk genoeg, natuur heeft geen prioriteit

2. Geen tijd

3. Ander vrijwilligerswerk

4. Onbekend met de mogelijkheden om iets te doen

5. Anders, namelijk

16. Welke van de volgende activiteiten voor de natuur heeft u de afgelopen 12 maanden wel eens ondernomen? Er zijn meerdere antwoorden mogelijk.

1. Onderhoud van natuur of landschap (bomen snoeien \& knotten, bermbeheer, poelen schonen, houtwallen afzetten etc.)

2. Aanleg van streekeigen beplanting bij mijn huis

3. Plaatsen van nestkastjes, voederplankjes bij mijn huis

4. Weidevogelbescherming

5. Inventarisatie van dier- of plantsoorten (bijv. tuinvogeltelling, waarneming.nl)

6. Geven van natuureducatie, lezingen en rondleidingen

7. Sociale activiteiten in de natuur organiseren (scouting, zorg, reizen etc)

8. Afval van anderen in de natuur opruimen

9. Anders, namelijk

10. Geen van deze

17. Welke van de volgende activiteiten heeft u de afgelopen 12 maanden wel eens ondernomen? Er zijn meerdere antwoorden mogelijk.

1. Buurtoverleg over groenbeheer bijgewoond

2. Actie gevoerd voor meer natuur of behoud van natuur

3. Naar inspraak- of informatieavond over natuur geweest

4. Brieven of opiniestukken geschreven over de natuur

5. Handtekening gezet voor de natuur

6. Protestmail gestuurd over de natuur

7. In mijn stemkeuze het onderwerp natuur mee laten wegen

8. Anders, namelijk

9. Geen van deze

18. Kent u projecten op het gebied van natuur en landschap in uw woonplaats waarbij burgers het initiatief hebben genomen om de natuur te verbeteren of te beschermen?

1. Ja

2. Nee (einde vragenlijst)

3. Weet ik niet (einde vragenlijst)

18a. $U$ heeft zojuist aangegeven dat u projecten kent op het gebied van natuur en landschap in uw woonplaats waarbij burgers het initiatief hebben genomen om de natuur te verbeteren of te beschermen. Om wat voor soort initiatief/initiatieven gaat het? Er zijn meerdere antwoorden mogelijk.

1. Het initiatief heeft betrekking op beheer en onderhoud (opruimen van afval, wilgen knotten, poelen schonen)

2. Het initiatief heeft betrekking op realisatie van nieuw groen (bijv. planten van bomen, inrichten van tuinen, bouwen vogelkijkhut)

3. Het initiatief heeft betrekking op actievoeren (bijv. protestacties, inzamelen handtekeningen)

4. Het initiatief heeft betrekking op educatieve activiteiten (bijv. excursies, lezingen)

5. Andersoortig initiatief, namelijk 
18b. U heeft zojuist aangegeven dat u projecten kent op het gebied van natuur en landschap in uw woonplaats waarbij burgers het initiatief hebben genomen om de natuur te verbeteren of te beschermen. Hoe bent $\mathbf{u}$ betrokken bij een dergelijk initiatief? Er zijn meerdere antwoorden mogelijk.

1. Ik ben (één van de) initiatiefnemer(s)

2. Ik ontvang informatie over het initiatief

3. Ik werk mee aan de uitvoering van het initiatief

0. Geen van deze

Hartelijk dank voor uw medewerking.

Dit was de laatste vraag, de vragenlijst is nu afgerond.

$\mathrm{U}$ kunt dit venster afsluiten. 


\title{
Bijlage 3 Tabellen met significante verschillen op basis van sociaal- demografische kenmerken
}

\begin{abstract}
Deze bijlage bevat het overzicht van significante verschillen op basis van sociaal-demografische kenmerken, geordend per enquêtevraag in de volgorde waarin de vragen in het rapport worden besproken. Van een enquêtevraag zijn enkel de bevraagde items weergegeven, waarbij zich significante verschillen voordoen tussen de vergeleken groepen. Bevat een tabel geen rijen (zoals het geval is voor Tabel B3.4), dan betekent dit dat zich geen (significante) verschillen voordoen in antwoorden tussen de vergeleken groepen.
\end{abstract}

\section{BEHOREND BIJ HOOFDSTUK 4}

\section{Enquêtevraag 12}

Tabel B3.1 Verschil in mening (schaal 1-5) over belang van natuur naar geslacht

$\begin{array}{lccc}\text { Stelling } & \text { Man } & \text { Vrouw } & \text { sign } \\ \text { Al die aandacht } & 2,22 & 2,11 & * * \\ \text { We maken ons } & 2,51 & 2,36 & * * *\end{array}$

Verschil is significant voor $* p<0.05, * * p<0,01$ of $* * * p<0,001$

Tabel B3.2 Verschil in mening (schaal 1-5) over belang van natuur naar leeftijd

$\begin{array}{lcccc}\text { Stelling } & 15 \text { tot } 35 \text { jaar } & 35 \text { tot } 55 \text { jaar } & 55 \text { tot } 75 \text { jaar } & \text { sign } \\ \text { Al die aandacht } & 2,21 & 2,18 & 2,09 & * \\ \text { We maken ons } & 2,35 & 2,43 & 2,53 & * *\end{array}$

Verschil is significant voor $* p<0.05, * * p<0,01$ of $* * * p<0,001$

Tabel B3.3 Verschil in mening (schaal 1-5) over belang van natuur naar opleidingsniveau

$\begin{array}{lcccc}\text { Stelling } & \text { Laag } & \text { Midden } & \text { Hoog } & \text { sign } \\ \text { Al die aandacht } & 2,28 & 2,19 & 2,06 & * * * \\ \text { We maken ons } & 2,59 & 2,52 & 2,25 & * * * \\ \text { De natuur mag } & 3,13 & 3,00 & 2,74 & * * * \\ \text { Verschil is significant voor } * \mathrm{p}<0.05, * * \mathrm{p}<0,01 \text { of } * * * p<0,001 & & \end{array}$

Verschil is significant voor $* p<0.05, * * p<0,01$ of $* * * p<0,001$

Tabel B3.4 Verschil in mening (schaal 1-5) over belang van natuur naar etniciteit

$\begin{array}{lc}\text { Autochtonen en } & \text { Niet-westerse } \\ \text { Westerse } & \text { allochtonen } \\ \text { allochtonen } & \text { sign } \\ \text { Verschil is significant voor } * \mathrm{p}<0.05, * * \mathrm{p}<0,01 \text { of } * * * \mathrm{p}<0,001 & \end{array}$

Tabel B3.5 Verschil in mening (schaal 1-5) over belang van natuur naar stedelijkheid

$\begin{array}{lccc}\text { Stelling } & 4 \text { grote steden } & \text { Overig Nederland } & \text { sign } \\ \text { De overheid geeft } & 3,57 & 3,44 & * \\ \text { De natuur mag } & 2,82 & 2,95 & *\end{array}$

Verschil is significant voor $* p<0.05, * * p<0,01$ of $* * * p<0,001$

\section{Enquêtevraag 11}

Tabel B3.6 Verschil in mening (schaal 1-4) over dilemma's economie-natuur naar geslacht

Dilemma Man Vrouw sign

Verschil is significant voor $* p<0.05, * * p<0,01$ of $* * * p<0,001$ 
Tabel B3.7 Verschil in mening (schaal 1-4) over dilemma's economie-natuur naar leeftijd

\begin{tabular}{|c|c|c|c|c|}
\hline Dilemma & 15 tot 35 jaar & 35 tot 55 jaar & 55 tot 75 jaar & sign \\
\hline Winkels of groen ${ }^{1}$ & 3,06 & 3,21 & 3,25 & $* * *$ \\
\hline Woningen of natuur & 2,85 & 2,93 & 2,80 & $* *$ \\
\hline Groot- of kleinsch. lb ${ }^{1}$ & 2,49 & 2,66 & 2,81 & $* * *$ \\
\hline
\end{tabular}

Tabel B3.8 Verschil in mening (schaal 1-4) over dilemma's economie-natuur naar opleidingsniveau

\begin{tabular}{lcccc}
\multicolumn{1}{c}{ Dilemma } & Laag & Midden & Hoog & sign \\
Parkeren of veldjes & 2,90 & 3,03 & 3,05 & $* *$ \\
Wegen of rekeningrijden $^{1}$ & 2,42 & 2,57 & 2,75 & $* * *$ \\
Groot- of kleinsch. Ib ${ }^{1}$ & 2,46 & 2,66 & 2,76 & $* * *$
\end{tabular}

Verschil is significant voor $* p<0.05, * * p<0,01$ of $* * * p<0,001$

Tabel B3.9 Verschil in mening (schaal 1-4) over dilemma's economie-natuur naar etniciteit

\begin{tabular}{|c|c|c|c|}
\hline Dilemma & $\begin{array}{c}\text { Autochtonen en } \\
\text { Westerse } \\
\text { allochtonen }\end{array}$ & $\begin{array}{c}\text { Niet-westerse } \\
\text { allochtonen }\end{array}$ & sign \\
\hline Parkeren of veldjes & 3,03 & 2,90 & $*$ \\
\hline Woningen of natuur & 2,88 & 2,75 & $* *$ \\
\hline Groot- of kleinsch. lb ${ }^{1}$ & 2,68 & 2,47 & $* * *$ \\
\hline
\end{tabular}

Tabel B3.10 Verschil in mening (schaal 1-4) over dilemma's economie-natuur naar stedelijkheid

$\begin{array}{lccc}\text { Dilemma } & 4 \text { grote steden } & \text { Overig Nederland } & \text { sign } \\ \text { Winkels of groen }{ }^{1} & 3.33 & 3,15 & * * * \\ \text { Rekeningrijden of wegen } & 2,14 & 2,43 & * * * \\ \text { Verschil is significant voor } * \mathrm{p}<0.05, * * \mathrm{p}<0,01 \text { of } * * * \mathrm{p}<0,001 & & \\ & \end{array}$

\section{Enquêtevraag 4}

Tabel B3.11 Verschil in mening (schaal 1-5) over waarom natuur belangrijk is naar geslacht

$\begin{array}{lccc}\text { Reden } & \text { Man } & \text { Vrouw } & \text { sign } \\ \text { Recreatie } & 4,25 & 4,35 & * * * \\ \text { Genieten } & 4,36 & 4,47 & * * * \\ \text { Gezondheid } & 4,56 & 4,62 & * * \\ \text { Kinderen } & 4,45 & 4,51 & * \\ \text { Geld verdienen } & 3,05 & 3,14 & * \\ \text { Oorsprong } & 3,72 & 3,87 & * *\end{array}$

Verschil is significant voor $* p<0.05, * * p<0,01$ of $* * * p<0,001$

Tabel B3.12 Verschil in mening (schaal 1-5) over waarom natuur belangrijk is naar leeftijd

$\begin{array}{lcccc}\text { Reden } & 15 \text { tot } 35 \text { jaar } & 35 \text { tot } 55 \text { jaar } & 55 \text { tot } 75 \text { jaar } & \text { sign } \\ \text { Genieten } & 4,38 & 4,40 & 4,46 & * \\ \text { Gezondheid } & 4,58 & 4,56 & 4,63 & * * \\ \text { Kinderen } & 4,40 & 4,48 & 4,56 & * * \\ \text { Oorsprong } & 3,60 & 3,86 & 4,91 & * * \\ \text { Wetenschap } & 4,03 & 4,07 & 4,18 & * * \\ \text { Landbouw } & 4,26 & 4,33 & 4 *\end{array}$

Verschil is significant voor $* p<0.05, * * p<0,01$ of $* * * p<0,001$ 
Tabel B3.13 Verschil in mening (schaal 1-5) over waarom natuur belangrijk is naar opleidingsniveau

$\begin{array}{lcccc} & \text { Laag } & \text { Midden } & \text { Hoog } & \text { sign } \\ \text { Genieten } & 4,43 & 4,45 & 4,37 & * \\ \text { Gezondheid } & 4,58 & 4,56 & 4,63 & * \\ \text { Geld verdienen } & 3,26 & 3,17 & 2,91 & * * * \\ \text { Oorsprong } & 3,91 & 3,92 & 3,58 & * * * \\ \text { Verschil is significant voor } * \mathrm{p}<0.05, * * \mathrm{p}<0,01 \text { of } * * * \mathrm{p}<0,001 & & & \end{array}$

Tabel B3.14 Verschil in mening (schaal 1-5) over waardering hoeveelheid natuur naar etniciteit

\begin{tabular}{|c|c|c|c|}
\hline Reden & $\begin{array}{c}\text { Autochtonen en } \\
\text { Westerse } \\
\text { allochtonen }\end{array}$ & $\begin{array}{c}\text { Niet-westerse } \\
\text { allochtonen }\end{array}$ & sign \\
\hline Recreatie & 4,31 & 4,20 & $* *$ \\
\hline Kinderen & 4,50 & 4,38 & $*$ \\
\hline
\end{tabular}

Verschil is significant voor $* p<0.05, * * p<0,01$ of $* * * p<0,001$

Tabel B3.15 Verschil in mening (schaal 1-5) over waarom natuur belangrijk is naar stedelijkheid

$\begin{array}{lccc}\text { Reden } & 4 \text { grote steden } & \text { Overig Nederland } & \text { sign } \\ \text { Recreatie } & 4,37 & 4,29 & * \\ \text { Genieten } & 4,48 & 4,40 & * \\ \text { Wetenschap } & 4,22 & 4,07 & * * \\ \text { Landbouw } & 4,41 & 4,32 & *\end{array}$

Verschil is significant voor $* p<0.05, * * p<0,01$ of $* * * p<0,001$

\section{Enquêtevraag 13}

Tabel B3.16 Verschil in mening (schaal 1-5) over de omgang met natuur naar geslacht

$\begin{array}{lccc}\text { Stelling } & \text { Man } & \text { Vrouw } & \text { sign } \\ \text { Dode bomen } & 2,73 & 2,91 & * * * \\ \text { Hoe langer } & 3,77 & 3,68 & * \\ \text { Het in koude } & 3,07 & 2,59 & * * * \\ \text { Bomen en struiken } & 3,59 & 2,90 & * * * \\ \text { Om een gebied } & 3,11 & 3,22 & * * * \\ \text { Als dieren } & 3,54 & & * * *\end{array}$

Tabel B3.17 Verschil in mening (schaal 1-5) over de omgang met natuur naar leeftijd

$\begin{array}{lcccc}\text { Stelling } & 15 \text { tot } 35 \text { jaar } & 35 \text { tot } 55 \text { jaar } & 55 \text { tot } 75 \text { jaar } & \text { sign } \\ \text { Dode bomen } & 3,02 & 2,77 & 2,69 & * * * \\ \text { In de natuur } & 3,92 & 3,93 & 4,01 & * \\ \text { Om de natuur } & 3,66 & 3,72 & 3,58 & * * \\ \text { Bermen } & 3,49 & 3,41 & 3,20 & * * \\ \text { Bomen en struiken } & 3,47 & 3,58 & 3,55 & * \\ \text { Als dieren } & 3,37 & 3,28 & 3,50 & * * *\end{array}$

Verschil is significant voor $* p<0.05, * * p<0,01$ of $* * * p<0,001$

Tabel B3.18 Verschil in mening (schaal 1-5) over de omgang met natuur naar opleidingsniveau

$\begin{array}{lcccc}\text { Stelling } & \text { Laag } & \text { Midden } & \text { Hoog } & \text { sign } \\ \text { Dode bomen } & 3,05 & 2,87 & 2,61 & * * * \\ \text { Hoe langer } & 3,78 & 3,74 & 3,67 & * \\ \text { In de natuur } & 4,02 & 3,98 & 3,89 & * * \\ \text { Om de natuur } & 3,62 & 3,62 & 3,71 & * \\ \text { Bermen } & 3,67 & 3,44 & 3,12 & * * * \\ \text { Hoogspanningsmasten } & 3,57 & 3,36 & 3,24 & * * * \\ \text { Het in koude } & 2,65 & 2,77 & 3,01 & * * *\end{array}$




\begin{tabular}{|c|c|c|c|c|}
\hline Stelling & Laag & Midden & Hoog & sign \\
\hline Bomen en struiken & 3,49 & 3,52 & 3,59 & $*$ \\
\hline Om een gebied & 3,14 & 2,96 & 2,98 & $* *$ \\
\hline Als dieren & 3,26 & 3,31 & 3,52 & $* * *$ \\
\hline
\end{tabular}

Tabel B3.19 Verschil in mening (schaal 1-5) over de omgang met natuur naar etniciteit

\begin{tabular}{|c|c|c|c|}
\hline Stelling & $\begin{array}{c}\text { Autochtonen en } \\
\text { Westerse } \\
\text { allochtonen }\end{array}$ & $\begin{array}{c}\text { Niet-westerse } \\
\text { allochtonen }\end{array}$ & sign \\
\hline Dode bomen & 2,78 & 3,09 & $* * *$ \\
\hline Bermen & 3,34 & 3,61 & $* * *$ \\
\hline Hoogspanningsmasten & 3,34 & 3,50 & $*$ \\
\hline
\end{tabular}

Verschil is significant voor $* p<0.05, * * p<0,01$ of $* * * p<0,001$

Tabel B3.20 Verschil in mening (schaal 1-5) over de omgang met natuur naar stedelijkheid

Stelling 4 grote steden Overig Nederland sign

Verschil is significant voor $* p<0.05, * * p<0,01$ of $* * * p<0,001$

\section{Enquêtevragen 2 en 3}

Tabel B3.21 Verschil in mening (schaal 1-5) over waardering hoeveelheid natuur naar geslacht

Hoeveelheid natur Man Vrouw

Tabel B3.22 Verschil in mening (schaal 1-5) over waardering hoeveelheid natuur naar leeftijd

\begin{tabular}{|c|c|c|c|c|}
\hline Hoeveelheid natuur & 15 tot 35 jaar & 35 tot 55 jaar & 55 tot 75 jaar & sign \\
\hline In woonomgeving & 2,94 & 2,91 & 3,02 & $2,96 *$ \\
\hline
\end{tabular}

Tabel B3.23 Verschil in mening (schaal 1-5) over waardering hoeveelheid natuur naar opleidingsniveau

Hoeveelheid natur Lag Hoog

Verschil is significant voor $* p<0.05, * * p<0,01$ of $* * * p<0,001$

Tabel B3.24 Verschil in mening (schaal 1-5) over waardering hoeveelheid natuur naar etniciteit

\begin{tabular}{|c|c|c|c|}
\hline Hoeveelheid natuur & $\begin{array}{c}\text { Autochtonen en } \\
\text { Westerse } \\
\text { allochtonen }\end{array}$ & $\begin{array}{l}\text { Niet-westerse } \\
\text { allochtonen }\end{array}$ & sign \\
\hline In Nederland & 2,61 & 2,79 & $* *$ \\
\hline
\end{tabular}

Verschil is significant voor $* \mathrm{p}<0.05, * * \mathrm{p}<0,01$ of $* * * \mathrm{p}<0,001$

Tabel B3.25 Verschil in mening (schaal 1-5) over waardering hoeveelheid natuur naar stedelijkheid

$\begin{array}{lccc}\begin{array}{l}\text { Hoeveelheid natur } \\ \text { steden }\end{array} & \text { Overig Nederland } & \text { sign } \\ \text { In Nederland } & 2,46 & 2,66 & * * * \\ \text { In woonomgeving } & 2,60 & 3,01\end{array}$




\section{BEHOREND BIJ HOOFDSTUK 5}

\section{Enquêtevraag 1}

Tabel B3.26 Verschil in mening over prioritaire overheidsonderwerpen naar geslacht

$\begin{array}{llcc}\text { Onderwerp } & \text { Man } & \text { Vrouw } & \text { sign } \\ \text { Gezondheidszorg } & 69 \% & 81 \% & * * * \\ \text { Immigratie en integratie } & 28 \% & 21 \% & * * * \\ \text { Sociale zekerheid } & 43 \% & 38 \% & * \\ \text { Ouderen } & 28 \% & 36 \% & * * *\end{array}$

Verschil is significant voor $* \mathrm{p}<0.05, * * \mathrm{p}<0,01$ of $* * * \mathrm{p}<0,001$

Tabel B3.27 Verschil in mening over prioritaire overheidsonderwerpen naar leeftijd

\begin{tabular}{|c|c|c|c|c|}
\hline Onderwerp & 15 tot 35 jaar & 35 tot 55 jaar & 55 tot 75 jaar & sign \\
\hline Gezondheidszorg & $70 \%$ & $80 \%$ & $75 \%$ & $* * *$ \\
\hline Milieu- en klimaat & $42 \%$ & $31 \%$ & $39 \%$ & $* * *$ \\
\hline Sociale zekerheid & $36 \%$ & $45 \%$ & $40 \%$ & $* *$ \\
\hline Onderwijs & $62 \%$ & $49 \%$ & $41 \%$ & $* * *$ \\
\hline Werkgelegenheid & $47 \%$ & $47 \%$ & $39 \%$ & $* *$ \\
\hline Normen en waarden & $24 \%$ & $23 \%$ & $29 \%$ & $* *$ \\
\hline Ouderen & $19 \%$ & $31 \%$ & $45 \%$ & $* * *$ \\
\hline Geen van deze & $2 \%$ & $1 \%$ & $0 \%$ & $* *$ \\
\hline
\end{tabular}

Verschil is significant voor $* p<0.05, * * p<0,01$ of $* * * p<0,001$

Tabel B3.28 Verschil in mening over prioritaire overheidsonderwerpen naar opleidingsniveau

$\begin{array}{lcccc}\text { Onderwerp } & \text { Laag } & \text { Midden } & \text { Hoog } & \text { Sign } \\ \text { Misdaad en terrorisme } & 49 \% & 45 \% & 39 \% & * * \\ \text { Milieu- en klimaat } & 25 \% & 31 \% & 51 \% & * * * \\ \text { Onderwijs } & 33 \% & 47 \% & 66 \% & * * * \\ \text { Normen en waarden } & 31 \% & 28 \% & 19 \% & * * * \\ \text { Ouderen } & 52 \% & 35 \% & 16 \% & * * *\end{array}$

Verschil is significant voor $* p<0.05, * * p<0,01$ of $* * * p<0,001$

Tabel B3.29 Verschil in mening over prioritaire overheidsonderwerpen naar etniciteit

$\begin{array}{lccc}\text { Onderwerp } & \begin{array}{c}\text { Autochtonen en } \\ \text { Westerse } \\ \text { allochtonen }\end{array} & \begin{array}{c}\text { Niet-westerse allochtonen } \\ \text { Niet- } \\ \text { westerse } \\ \text { allochtonen }\end{array} \\ \text { Gezondheidszorg } & 76 \% & 69 \% & * \\ \text { Onderwijs } & 50 \% & 59 \% & * * \\ \text { Ouderen } & 33 \% & 21 \% & * * * \\ \text { Geen van deze } & 1 \% & 3 \% & *\end{array}$

Verschil is significant voor $* p<0.05, * * p<0,01$ of $* * * p<0,001$

Tabel B3.30 Verschil in mening over prioritaire overheidsonderwerpen naar stedelijkheid

$\begin{array}{lccc}\text { Onderwerp } & \begin{array}{c}\text { grote } \\ \text { steden }\end{array} & \text { Overig Nederland } & \text { Sign } \\ \text { Gezondheidszorg } & 67 \% & 77 \% & * * \\ \text { Misdaad en terrorisme } & 38 \% & 44 \% & * \% \\ \text { Milieu- en klimaat } & 43 \% & 33 \% & * * \\ \text { Ouderen } & 24 \% & & * * \\ \text { Verschil is significant voor } * \mathrm{p}<0.05, * * p<0,01 \text { of } * * * \mathrm{p}<0,001 & \end{array}$

Verschil is significant voor $* p<0.05, * * p<0,01$ of $* * * p<0,001$ 


\section{Enquêtevraag 14}

Tabel B3.31 Verschil in mening over wie verantwoordelijkheid (schaal 1-3) heeft voor natuur in natuurgebieden naar geslacht

$\begin{array}{lccc}\text { geslacht } & \text { Man } & \text { Vrouw } & \text { sign } \\ \text { Actor } & 1,30 & 1,38 & * * * \\ \text { Overheid } & 1,87 & 1,80 & * * \\ \text { Natuurorganisaties } & 2,15 & 2,09 & * * \\ \text { Overig bedrijfsleven } & 2,05 & 2,02 & *\end{array}$

Verschil is significant voor $* p<0.05, * * p<0,01$ of $* * * p<0,001$

Tabel B3.32 Verschil in mening over wie verantwoordelijkheid (schaal 1-3) heeft voor natuur in natuurgebieden naar leeftijd

$\begin{array}{lcccc}\text { Type gebied } & 15 \text { tot } 35 \text { jaar } & 35 \text { tot } 55 \text { jaar } & 55 \text { tot } 75 \text { jaar } & \text { sign } \\ \text { Overheid } & 1,30 & 1,33 & 1,39 & * * \\ \text { Natuurorganisaties } & 1,88 & 1,87 & 1,75 & * * * \\ \text { Burgers } & 2,08 & 2,03 & 1,99 & * * *\end{array}$

Verschil is significant voor $* p<0.05, * * p<0,01$ of $* * * p<0,001$

Tabel B3.33 Verschil in mening over wie verantwoordelijkheid (schaal 1-3) heeft voor natuur in natuurgebieden naar opleidingsniveau

$\begin{array}{lcccc}\text { Type gebied } & \text { Laag } & \text { Midden } & \text { Hoog } & \text { sign } \\ \text { Overheid } & 1,38 & 1,36 & 1,29 & * * \\ \text { Landbouwbedrijven } & 1,97 & 1,99 & 2,07 & * * * \\ \text { Overig bedrijfsleven } & 2,11 & 2,10 & 2,15 & * \\ \text { Burgers } & 2,03 & 2,01 & 2,06 & *\end{array}$

Verschil is significant voor $* p<0.05, * * p<0,01$ of $* * * p<0,001$

Tabel B3.34 Verschil in mening over wie verantwoordelijkheid (schaal 1-3) heeft voor natuur in natuurgebieden naar etniciteit

$\begin{array}{ccc}\text { Type gebied } & \text { Autochtonen en } & \text { Niet-westerse } \\ \text { Westerse allochtonen } & \text { allochtonen }\end{array}$

Verschil is significant voor $* p<0.05, * * p<0,01$ of $* * * p<0,001$

Tabel B3.35 Verschil in mening over wie verantwoordelijkheid (schaal 1-3) heeft voor natuur in natuurgebieden naar stedelijkheid

$\begin{array}{lccc}\text { Type gebied } & 4 \text { grote steden } & \text { Overig Nederland } & \text { sign } \\ \text { Overheid } & 1,27 & 1,35 & * * \\ \text { Natuurorganisaties } & 1,90 & 1,83 & * \\ \text { Verschil is significant voor } * \mathrm{p}<0.05, * * \mathrm{p}<0,01 \text { of } * * * \mathrm{p}<0,001 & & \end{array}$

\section{Enquêtevraag 14-vervolg 1}

Tabel B3.36 Verschil in mening over wie verantwoordelijkheid (schaal 1-3) heeft voor natuur op het platteland naar geslacht

\begin{tabular}{|c|c|c|c|}
\hline Actor & Man & Vrouw & sign \\
\hline Overheid & 1,42 & 1,49 & $* * *$ \\
\hline Natuurorganisaties & 1,96 & 1,89 & $* *$ \\
\hline Overig bedrijfsleven & 2,20 & 2,11 & $* * *$ \\
\hline Burgers & 2,20 & 2,11 & $* * *$ \\
\hline
\end{tabular}

Tabel B3.37 Verschil in mening over wie verantwoordelijkheid (schaal 1-3) heeft voor natuur op het platteland naar leeftijd

$\begin{array}{lcccc}\text { Type gebied } & 15 \text { tot } 35 \text { jaar } & 35 \text { tot } 55 \text { jaar } & 55 \text { tot } 75 \text { jaar } & \text { sign } \\ \text { Overheid } & 1,44 & 1,42 & 1,51 & * * * \\ \text { Natuurorganisaties } & 2,00 & 1,94 & 1,84 & * * * \\ \text { Burgers } & 2,23 & 2,13 & 2,12 & * * *\end{array}$

Verschil is significant voor $* p<0.05, * * p<0,01$ of $* * * p<0,001$

102 | wOt-technical report 102 
Tabel B3.38 Verschil in mening over wie verantwoordelijkheid (schaal 1-3) heeft voor natuur op het platteland naar opleidingsniveau

$\begin{array}{lcccc}\text { Opleidingsniveau } & & & & \\ \text { Type gebied } & \text { Laag } & \text { Midden } & \text { Hoog } & * * \\ \text { Overheid } & 1,48 & 1,48 & 1,40 & * * * \\ \text { Natuurorganisaties } & 1,92 & 1,88 & 2,98 & * * \\ \text { Overig bedrijfsleven } & 2,11 & 2,14 & 2,20 & * * \\ \text { Burgers } & 2,12 & 2,14 & & \end{array}$

Verschil is significant voor $* p<0.05, * * p<0,01$ of $* * * p<0,001$

Tabel B3.39 Verschil in mening over wie verantwoordelijkheid (schaal 1-3) heeft voor natuur op het platteland naar etniciteit

\begin{tabular}{|c|c|c|c|}
\hline Type gebied & $\begin{array}{c}\text { Autochtonen en } \\
\text { Westerse } \\
\text { allochtonen }\end{array}$ & $\begin{array}{c}\text { Niet-westerse } \\
\text { allochtonen }\end{array}$ & sign \\
\hline Overheid & 1,44 & 1,55 & $* *$ \\
\hline Burgers & 2,15 & 2,22 & $*$ \\
\hline
\end{tabular}

Verschil is significant voor $* p<0.05, * * p<0,01$ of $* * * p<0,001$

Tabel B3.40 Verschil in mening over wie verantwoordelijkheid (schaal 1-3) heeft voor natuur op het platteland naar stedelijkheid

$\begin{array}{lccc}\text { Type gebied } & 4 \text { grote steden } & \text { Overig Nederland } & \text { sign } \\ \text { Overheid } & 1,37 & 1,47 & * * \\ \text { Natuurorganisaties } & 2,01 & 1,91 & * * \\ \text { Verschil is significant voor } * \mathrm{p}<0.05, * * \mathrm{p}<0,01 \text { of } * * * \mathrm{p}<0,001 & & \end{array}$

\section{Enquêtevraag 14-vervolg 2}

Tabel B3.41 Verschil in mening over wie verantwoordelijkheid (schaal 1-3) heeft voor natuur in de stad naar geslacht

$\begin{array}{lccc}\text { Actor } & \text { Man } & \text { Vrouw } & \text { sign } \\ \text { Overheid } & 1,26 & 1,32 & * * \\ \text { Landbouwbedrijven } & 2,56 & 2,43 & * * * \\ \text { Natuurorganisaties } & 2,05 & 1,93 & * * * \\ \text { Overig bedrijfsleven } & 2,06 & 1,97 & * * *\end{array}$

Verschil is significant voor $* p<0.05, * * p<0,01$ of $* * * p<0,001$

Tabel B3.42 Verschil in mening over wie verantwoordelijkheid (schaal 1-3) heeft voor natuur in de stad naar leeftijd

$\begin{array}{lcccc}\text { Type gebied } & 15 \text { tot } 35 \text { jaar } & 35 \text { tot } 55 \text { jaar } & 55 \text { tot } 75 \text { jaar } & \text { sign } \\ \text { Landbouwbedrijven } & 2,43 & 2,44 & 2,62 & * * * \\ \text { Overig bedrijfsleven } & 1,97 & 2,02 & 2,05 & * * \\ \text { Burgers } & 1,99 & 1,95 & 1,91 & * *\end{array}$

Verschil is significant voor $* p<0.05, * * p<0,01$ of $* * * p<0,001$

Tabel B3.43 Verschil in mening over wie verantwoordelijkheid (schaal 1-3) heeft voor natuur in de stad naar opleidingsniveau

$\begin{array}{lcccc}\text { Type gebied } & \text { Laag } & \text { Midden } & \text { Hoog } & \text { sign } \\ \text { Overheid } & 1,36 & 1,32 & 1,23 & * * * \\ \text { Landbouwbedrijven } & 2,48 & 2,45 & 2,56 & * * * \\ \text { Natuurorganisaties } & 1,95 & 1,97 & 2,05 & * * *\end{array}$

Verschil is significant voor $* p<0.05, * * p<0,01$ of $* * * p<0,001$

Tabel B3.44 Verschil in mening over wie verantwoordelijkheid (schaal 1-3) heeft voor natuur in de stad naar etniciteit

\begin{tabular}{|c|c|c|c|}
\hline Type gebied & $\begin{array}{l}\text { Autochtonen en } \\
\text { Westerse } \\
\text { allochtonen }\end{array}$ & $\begin{array}{c}\text { Niet-westerse } \\
\text { allochtonen }\end{array}$ & sign \\
\hline Landbouwbedrijven & 2,51 & 2,39 & $* *$ \\
\hline Overig bedrijfsleven & 2,02 & 1,94 & $* *$ \\
\hline
\end{tabular}

Verschil is significant voor $* p<0.05, * * p<0,01$ of $* * * p<0,001$ 
Tabel B3.45 Verschil in mening over wie verantwoordelijkheid (schaal 1-3) heeft voor natuur in de stad naar stedelijkheid

$\begin{array}{lccc}\text { Type gebied } & 4 \text { grote steden } & \text { Overig Nederland } & \text { sign } \\ \text { Overheid } & 1,21 & 1,30 & * *\end{array}$

Verschil is significant voor $* p<0.05, * * p<0,01$ of $* * * p<0,001$

\section{Enquêtevraag 9}

Tabel B3.46 Verschil in mening (schaal 1-5) over beschermingsmaatregelen naar geslacht

$\begin{array}{lccc}\text { Maatregel } & \text { Man } & \text { Vrouw } & \text { sign } \\ \text { Beschermen bestaande } & 4,38 & 4,47 & * * * \\ \text { Verbinden } & 3,90 & 3,81 & * * \\ \text { Beschermen zeldzame } & 4,29 & 4,43 & * * * \\ \text { Beheren } & 4,22 & 4,34 & * * * \\ \text { Beschermen platteland } & 4,15 & 4,27 & * * * \\ \text { Meer paden, bankjes } & 3,51 & 3,59 & * * * \\ \text { Meer natuur in de stad } & 3,89 & 4,05 & * \\ \text { Meer platteland } & 3,72 & 3,79 & * * \\ \text { Meer natuureducatie } & 4,07 & 4,16 & * * * \\ \text { Burgers betrekken } & 3,94 & 4,06 & * * *\end{array}$

Verschil is significant voor $* p<0.05, * * p<0,01$ of $* * * p<0,001$

Tabel B3.47 Verschil in mening (schaal 1-5) over beschermingsmaatregelen naar leeftijd

$\begin{array}{lcccc}\text { Maatregel } & 15 \text { tot } 35 \text { jaar } & 35 \text { tot } 55 \text { jaar } & 55 \text { tot } 75 \text { jaar } & \text { sign } \\ \text { Beschermen bestaande } & 4,39 & 4,40 & 4,48 & * \\ \text { Verbinden } & 3,79 & 3,85 & 3,94 & * * \\ \text { Beheren } & 4,23 & 4,28 & 4,33 & * * \\ \text { Beschermen platteland } & 4,09 & 4,22 & 3,30 & * * \\ \text { Meer paden, bankjes } & 3,48 & 3,55 & 3,63 & * * * \\ \text { Meer natuur platteland } & 3,63 & 3,78 & 4,20 & * *\end{array}$

Verschil is significant voor $* p<0.05, * * p<0,01$ of $* * * p<0,001$

Tabel B3.48 Verschil in mening (schaal 1-5) over beschermingsmaatregelen naar opleidingsniveau

$\begin{array}{lcccc}\text { Maatregel } & \text { Laag } & \text { Midden } & \text { Hoog } & \text { sign } \\ \text { Beschermen bestaande } & 4,36 & 4,43 & 4,44 & * \\ \text { Beschermen zeldzame } & 4,31 & 4,40 & 4,34 & * \\ \text { Beschermen platteland } & 4,23 & 4,24 & 4,16 & * * \\ \text { Meer paden, bankjes } & 3,73 & 3,60 & 3,39 & * * \\ \text { Meer natuur stad } & 4,02 & 4,00 & 3,63 & * * * \\ \text { Meer natuur platteland } & 3,83 & 3,83 & 3,98 & *\end{array}$

Verschil is significant voor $* p<0.05, * * p<0,01$ of $* * * p<0,001$

Tabel B3.49 Verschil in mening (schaal 1-5) over beschermingsmaatregelen naar etniciteit

\begin{tabular}{|c|c|c|c|}
\hline Maatregel & $\begin{array}{c}\text { Autochtonen en } \\
\text { Westerse } \\
\text { allochtonen }\end{array}$ & $\begin{array}{c}\text { Niet-westerse } \\
\text { allochtonen }\end{array}$ & sign \\
\hline Beheren & 4,27 & 4,38 & $* *$ \\
\hline Meer paden, bankjes & 3,54 & 3,68 & $* *$ \\
\hline Meer natuur in de stad & 3,95 & 4,09 & $* *$ \\
\hline Meer natuureducatie & 4,10 & 4,19 & $*$ \\
\hline Burgers betrekken & 3,99 & 4,13 & $* *$ \\
\hline Bedrijven betrekken & 4,12 & 4,33 & $* * *$ \\
\hline
\end{tabular}


Tabel B3.50 Verschil in mening (schaal 1-5) over beschermingsmaatregelen naar stedelijkheid

$\begin{array}{lccc}\text { Maatregel } & 4 \text { grote steden } & \text { Overig Nederland } & \text { sign } \\ \text { Beschermen bestaande } & 4,49 & 4,41 & * \\ \text { Aanleg } & 4,12 & 4,01 & * \\ \text { Verbinden } & 4,00 & 3,83 & * * * \\ \text { Beschermen zeldzame } & 4,47 & 4,27 & * * \\ \text { Beheren } & 4,37 & 3,94 & * * * \\ \text { Meer natuur in de stad } & 4,15 & 3,98 & * * * \\ \text { Burgers betrekken } & 4,14 & 4,12 & * * * \\ \text { Bedrijven betrekken } & 4,28 & & \end{array}$

\section{BEHOREND BIJ HOOFDSTUK 6}

\section{Enquêtevraag 15}

Tabel B3.51 Verschil in denken over betrokkenheid bij natuur naar geslacht

$\begin{array}{lccc}\text { Mogelijkheid } & \text { Man } & \text { Vrouw } & \text { sign } \\ \text { Geïnformeerd worden } & 44 \% & 49 \% & * * \\ \text { Meedenken } & 49 \% & 45 \% & * \\ \text { Zelf met } & 33 \% & 39 \% & * *\end{array}$

Verschil is significant voor $* p<0.05, * * p<0,01$ of $* * * p<0,001$

Tabel B3.52 Verschil in denken over betrokkenheid bij natuur naar leeftijd

$\begin{array}{lcccc}\text { Mogelijkheid } & 15 \text { tot } 35 \text { jaar } & 35 \text { tot } 55 \text { jaar } & 55 \text { tot } 75 \text { jaar } & \text { sign } \\ \text { Geïnformeerd worden } & 53 \% & 44 \% & 43 \% & * * * \\ \text { Meedenken } & 42 \% & 46 \% & 53 \% & * * *\end{array}$

Verschil is significant voor $* p<0.05, * * p<0,01$ of $* * * p<0,001$

Tabel B3.53 Verschil in denken over betrokkenheid bij natuur naar opleidingsniveau

$\begin{array}{llccc}\text { Mogelijkheid } & \text { Laag } & \text { Midden } & \text { Hoog } & \text { sign } \\ \text { Geïnformeerd worden } & 37 \% & 46 \% & 52 \% & * * \\ \text { Meedenken } & 45 \% & 44 \% & 52 \% & * * \\ \text { Vrijwilligerswerk } & 18 \% & 25 \% & 32 \% & * * \\ \text { Zelf met } & 36 \% & 34 \% & 40 \% & * \\ \text { Ik wil niet } & 21 \% & 19 \% & 15 \% & * *\end{array}$

Verschil is significant voor $* p<0.05, * * p<0,01$ of $* * * p<0,001$

Tabel B3.54 Verschil in denken over betrokkenheid bij natuur naar etniciteit

\begin{tabular}{|c|c|c|c|}
\hline Mogelijkheid & $\begin{array}{c}\text { Autochtonen en } \\
\text { Westerse } \\
\text { allochtonen }\end{array}$ & $\begin{array}{c}\text { Niet-westerse } \\
\text { allochtonen }\end{array}$ & sign \\
\hline Meedenken & $48 \%$ & $40 \%$ & $* *$ \\
\hline Ik wil niet & $17 \%$ & $22 \%$ & $*$ \\
\hline
\end{tabular}

Verschil is significant voor $* p<0.05, * * p<0,01$ of $* * * p<0,001$

Tabel B3.55 Verschil in denken over betrokkenheid bij natuur naar stedelijkheid

\begin{tabular}{|c|c|c|c|}
\hline Mogelijkheid & 4 grote steden & Overig Nederland & sign \\
\hline Geïnformeerd worden & $52 \%$ & $46 \%$ & $*$ \\
\hline
\end{tabular}




\section{Enquêtevraag 15A}

Tabel B3.56 Verschil in mening (schaal 1-5) over waarom natuur belangrijk is naar geslacht

\begin{tabular}{|c|c|c|c|}
\hline Reden & Man & Vrouw & sign \\
\hline Betrokkenheid & $44 \%$ & $52 \%$ & $* *$ \\
\hline Leuk & $19 \%$ & $15 \%$ & $* *$ \\
\hline Morele & $10 \%$ & $7 \%$ & $* *$ \\
\hline
\end{tabular}

Verschil is significant voor $* p<0.05, * * p<0,01$ of $* * * p<0,001$

Tabel B3.57 Verschil in mening (schaal 1-5) over waarom natuur belangrijk is naar leeftijd

\begin{tabular}{|c|c|c|c|c|}
\hline Reden & 15 tot 35 jaar & 35 tot 55 jaar & 55 tot 75 jaar & sign \\
\hline Betrokkenheid & $36 \%$ & $46 \%$ & $61 \%$ & $* * *$ \\
\hline Leuk & $21 \%$ & $16 \%$ & $14 \%$ & $* *$ \\
\hline Actief & $38 \%$ & $43 \%$ & $51 \%$ & $* * *$ \\
\hline Nuttige contacten & $3 \%$ & $4 \%$ & $6 \%$ & $*$ \\
\hline Zinvolle tijdsbesteding & $23 \%$ & $22 \%$ & $28 \%$ & $*$ \\
\hline Iets voor maatschappij & $43 \%$ & $38 \%$ & $30 \%$ & $* * *$ \\
\hline Sociale erkenning & $2 \%$ & $6 \%$ & $4 \%$ & $* *$ \\
\hline
\end{tabular}

Verschil is significant voor $* p<0.05, * * p<0,01$ of $* * * p<0,001$

Tabel B3.58 Verschil in mening (schaal 1-5) over waarom natuur belangrijk is naar opleidingsniveau

$\begin{array}{lcccc}\text { Reden } & \text { Laag } & \text { Midden } & \text { Hoog } & \text { sign } \\ \text { Nieuwe kennis } & 13 \% & 17 \% & 21 \% & * * \\ \text { Nuttige contacten } & 7 \% & 5 \% & 2 \% & * * * \\ \text { Iets voor maatschappij } & 27 \% & 35 \% & 44 \% & * * * \\ \text { Sociale erkenning } & 8 \% & 4 \% & 2 \% & * * *\end{array}$

Verschil is significant voor $* p<0.05, * * p<0,01$ of $* * * p<0,001$

Tabel B3.59 Verschil in mening (schaal 1-5) over waardering hoeveelheid natuur naar etniciteit

\begin{tabular}{|c|c|c|c|}
\hline Reden & $\begin{array}{c}\text { Autochtonen en } \\
\text { Westerse } \\
\text { allochtonen }\end{array}$ & $\begin{array}{c}\text { Niet-westerse } \\
\text { allochtonen }\end{array}$ & sign \\
\hline Betrokkenheid & $49 \%$ & $39 \%$ & $* *$ \\
\hline Verbreden & $8 \%$ & $16 \%$ & $* *$ \\
\hline Iets voor maatschappij & $36 \%$ & $43 \%$ & $*$ \\
\hline
\end{tabular}

Verschil is significant voor $* p<0.05, * * p<0,01$ of $* * * p<0,001$

Tabel B3.60 Verschil in mening (schaal 1-5) over waarom natuur belangrijk is naar stedelijkheid

$\begin{array}{lccc}\text { Reden } & 4 \text { grote steden } & \text { Overig Nederland } & \text { sign } \\ \text { Leuk } & 13 \% & 18 \% & * \\ \text { Nuttige contacten } & 2 \% & 5 \% & * \\ \text { Sociale erkenning } & 2 \% & 4 \% & * \\ \text { Anders } & 1 \% & 3 \% & *\end{array}$

Verschil is significant voor $* p<0.05, * * p<0,01$ of $* * * p<0,001$

\section{Enquêtevraag 15B}

Tabel B3.61 Verschil in mening (schaal 1-5) over niet betrokken willen zijn naar geslacht

$\begin{array}{lccc}\text { Reden } & \text { Man } & \text { Vrouw } & \text { sign } \\ \text { Niet belangrijk } & 14 \% & 6 \% & * * \\ \text { Geen tijd } & 66 \% & 53 \% & * * \\ \text { Ander vrijwilligerswerk } & 15 \% & 24 \% & * \\ \text { Anders } & 8 \% & 15 \% & *\end{array}$

Verschil is significant voor $* p<0.05, * * p<0,01$ of $* * * p<0,001$ 
Tabel B3.62 Verschil in mening (schaal 1-5) over niet betrokken willen zijn naar leeftijd

\begin{tabular}{|c|c|c|c|c|}
\hline Reden & 15 tot 35 jaar & 35 tot 55 jaar & 55 tot 75 jaar & sign \\
\hline Niet belangrijk & $17 \%$ & $6 \%$ & $8 \%$ & $* *$ \\
\hline Geen tijd & $77 \%$ & $62 \%$ & $38 \%$ & $* * *$ \\
\hline Ander vrijwilligerswerk & $10 \%$ & $20 \%$ & $29 \%$ & $* * *$ \\
\hline Anders & $1 \%$ & $15 \%$ & $19 \%$ & $* * *$ \\
\hline
\end{tabular}

Tabel B3.63 Verschil in mening (schaal 1-5) over niet betrokken willen zijn naar opleidingsniveau

$\begin{array}{lcccc}\text { Reden } & \text { Laag } & \text { Midden } & \text { Hoog } & \text { sign } \\ \text { Niet belangrijk } & 9 \% & 7 \% & 16 \% & * \\ \text { Geen tijd } & 50 \% & 61 \% & 67 \% & * \\ \text { Onbekend } & 22 \% & 12 \% & 6 \% & * *\end{array}$

Verschil is significant voor $* p<0.05, * * p<0,01$ of $* * * p<0,001$

Tabel B3.64 Verschil in mening (schaal 1-5) over niet betrokken willen zijn naar etniciteit

\begin{tabular}{|c|c|c|c|}
\hline Reden & $\begin{array}{c}\text { Autochtonen en } \\
\text { Westerse } \\
\text { allochtonen }\end{array}$ & $\begin{array}{c}\text { Niet-westerse } \\
\text { allochtonen }\end{array}$ & sign \\
\hline Geen tijd & $57 \%$ & $73 \%$ & $*$ \\
\hline Ander vrijwilligerswerk & $21 \%$ & $8 \%$ & $* *$ \\
\hline Anders & $13 \%$ & $4 \%$ & $* *$ \\
\hline
\end{tabular}

Verschil is significant voor $* p<0.05, * * p<0,01$ of $* * * p<0,001$

Tabel B3.65 Verschil in mening (schaal 1-5) over niet betrokken willen zijn naar stedelijkheid

$\begin{array}{lccc}\text { Reden } & 4 \text { grote steden } & \text { Overig Nederland } & \text { sign } \\ \text { Geen tijd } & 80 \% & 57 \% & * * * \\ \text { Onbekend } & 3 \% & 14 \% & * * * \\ \text { Verschil is significant voor } * \mathrm{p}<0.05, * * \mathrm{p}<0,01 \text { of } * * * \mathrm{p}<0,001 & & \end{array}$

Verschil is significant voor $* p<0.05, * * p<0,01$ of $* * * p<0,001$

\section{Enquêtevraag 5}

Tabel B3.66 Verschil in bezoek natuur (schaal 1-5) naar geslacht

Type natuur Man Vrouw sign

Verschil is significant voor $* p<0.05, * * p<0,01$ of $* * * p<0,001$

Tabel B3.67 Verschil in bezoek natuur (schaal 1-5) naar leeftijd

$\begin{array}{lcccc}\text { Type natuur } & \mathbf{1 5} \text { tot } 35 \text { jaar } & 35 \text { tot } 55 \text { jaar } & 55 \text { tot } 75 \text { jaar } & \text { sign } \\ \text { Parken } & 2,68 & 2,58 & 2,74 & * \\ \text { Platteland } & 2,57 & 2,83 & 3,03 & * * * \\ \text { Natuurgebied } & 2,71 & 2,76 & 2,86 & * *\end{array}$

Verschil is significant voor $* p<0.05, * * p<0,01$ of $* * *<0,001$

Tabel B3.68 Verschil in bezoek natuur (schaal 1-5) naar opleidingsniveau

$\begin{array}{lcccc}\text { Type natuur } & \text { Laag } & \text { Midden } & \text { Hoog } & \text { sign } \\ \text { Parken } & 2,56 & 2,63 & 2,76 & * *\end{array}$

Verschil is significant voor $* p<0.05, * * p<0,01$ of $* * * p<0,001$

Tabel B3.69 Verschil in bezoek natuur (schaal 1-5) naar etniciteit

\begin{tabular}{|c|c|c|c|}
\hline Type natuur & $\begin{array}{c}\text { Autochtonen en } \\
\text { Westerse } \\
\text { allochtonen }\end{array}$ & $\begin{array}{l}\text { Niet-westerse } \\
\text { allochtonen }\end{array}$ & sign \\
\hline Platteland & 2,91 & 2,10 & $* * *$ \\
\hline Natuurgebied & 2,83 & 2,40 & $* * *$ \\
\hline
\end{tabular}

Verschil is significant voor $* p<0.05, * * p<0,01$ of $* * * p<0,001$ 
Tabel B3.70 Verschil in bezoek natuur (schaal 1-5) naar stedelijkheid

\begin{tabular}{|c|c|c|c|}
\hline Type natuur & 4 grote steden & Overig Nederland & sign \\
\hline Parken & 3,05 & 2,60 & $* * *$ \\
\hline Platteland & 2,17 & 2,91 & $* * *$ \\
\hline Natuurgebied & 2,42 & 2,83 & $* * *$ \\
\hline
\end{tabular}

Verschil is significant voor $* p<0.05, * * p<0,01$ of $* * * p<0,001$

\section{Enquêtevraag 6}

Tabel B3.71 Verschil in gebruik informatiebronnen naar geslacht

$\begin{array}{lccc}\text { Informatiebron } & \text { Man } & \text { Vrouw } & \text { sign } \\ \text { Internet } & 36 \% & 29 \% & * * * \\ \text { Sociale media } & 12 \% & 15 \% & *\end{array}$

Verschil is significant voor $* p<0.05, * * p<0,01$ of $* * * p<0,001$

Tabel B3.72 Verschil in gebruik informatiebronnen naar leeftijd

$\begin{array}{lcccc}\text { Informatiebron } & \mathbf{1 5} \text { tot } 35 \text { jaar } & 35 \text { tot } 55 \text { jaar } & 55 \text { tot } 75 \text { jaar } & \text { sign } \\ \text { Televisieprogramma } & 49 \% & 63 \% & 80 \% & * * * \\ \text { Tijdschrift } & 16 \% & 25 \% & 36 \% & * * * \\ \text { Webcams } & 5 \% & 6 \% & 8 \% & * * \\ \text { Sociale media } & 15 \% & 15 \% & 10 \% & * \\ \text { Apps } & 4 \% & 2 \% & 5 \% & * * \\ \text { Anders } & 2 \% & 4 \% & 5 \% & * * * \\ \text { Geen van deze } & 36 \% & 24 \% & & \end{array}$

Verschil is significant voor $* p<0.05, * * p<0,01$ of $* * * p<0,001$

Tabel B3.73 Verschil in gebruik informatiebronnen naar opleidingsniveau

\begin{tabular}{|c|c|c|c|c|}
\hline Informatiebron & Laag & Midden & Hoog & sign \\
\hline Televisieprogramma & $72 \%$ & $63 \%$ & $61 \%$ & $* * *$ \\
\hline Tijdschrift & $24 \%$ & $24 \%$ & $29 \%$ & $*$ \\
\hline Internet & $26 \%$ & $31 \%$ & $38 \%$ & $* * *$ \\
\hline
\end{tabular}

Tabel B3.74 Verschil in gebruik informatiebronnen naar etniciteit

$\begin{array}{lccc}\text { Informatiebron } & \begin{array}{c}\text { Autochtonen en } \\ \text { Westerse } \\ \text { allochtonen }\end{array} & \begin{array}{c}\text { Niet-westerse } \\ \text { allochtonen }\end{array} & \text { sign } \\ \text { Tijdschrift } & 27 \% & 19 \% & * * \\ \text { Internet } & 33 \% & 27 \% & * \% \\ \text { Webcams } & 7 \% & 2 \% & * * \\ \text { Apps } & 4 \% & 1 \% & * * * \\ \text { Anders } & 4 \% & 32 \% & * * \\ \text { Geen } & 23 \% & & \end{array}$

Tabel B3.75 Verschil in gebruik informatiebronnen naar stedelijkheid

\begin{tabular}{|c|c|c|c|}
\hline Informatiebron & 4 grote steden & Overig Nederland & sign \\
\hline Tijdschrift & $21 \%$ & $26 \%$ & $*$ \\
\hline
\end{tabular}




\section{Enquêtevraag 16}

Tabel B3.76 Verschil in ondernomen activiteiten voor natuur naar geslacht

$\begin{array}{lccc}\text { Activiteit } & \text { Man } & \text { Vrouw } & \text { sign } \\ \text { Plaatsen nestkastjes } & 27 \% & 35 \% & * * * \\ \text { Weidevogelbescherming } & 2 \% & 1 \% & * \\ \text { Geven natuureducatie } & 2 \% & 1 \% & * \\ \text { Afval } & 26 \% & 30 \% & * \\ \text { Anders } & 1 \% & 3 \% & * * *\end{array}$

Verschil is significant voor $* p<0.05, * * p<0,01$ of $* * * p<0,001$

Tabel B3.77 Verschil in ondernomen activiteiten voor natuur naar leeftijd

$\begin{array}{lcccc}\text { Activiteit } & 15 \text { tot } 35 \text { jaar } & 35 \text { tot } 55 \text { jaar } & 55 \text { tot } 75 \text { jaar } & \text { sign } \\ \text { Aanleg streekeigen } & 9 \% & 10 \% & 13 \% & * * \\ \text { Plaatsen nestkastjes } & 18 \% & 34 \% & 41 \% & * * * \\ \text { Weidevogelbescherming } & 3 \% & 1 \% & 1 \% & * * \\ \text { Geven natuureducatie } & 3 \% & 1 \% & 1 \% & * * \\ \text { Sociale activiteiten } & 8 \% & 4 \% & 3 \% & * * \\ \text { Afval } & 24 \% & 30 \% & 3 \% & * * \\ \text { Anders } & 0 \% & 2 \% & 37 \% & * * \\ \text { Geen van deze } & 50 \% & 44 \% & & * *\end{array}$

Verschil is significant voor $* p<0.05, * * p<0,01$ of $* * * p<0,001$

Tabel B3.78 Verschil in ondernomen activiteiten voor natuur naar opleidingsniveau

\begin{tabular}{|c|c|c|c|c|}
\hline Activiteit & Laag & Midden & Hoog & sign \\
\hline Plaatsen nestkastjes & $36 \%$ & $34 \%$ & $25 \%$ & $* * *$ \\
\hline Geven natuureducatie & $1 \%$ & $1 \%$ & $3 \%$ & $*$ \\
\hline Sociale activiteiten & $3 \%$ & $4 \%$ & $7 \%$ & $* * *$ \\
\hline
\end{tabular}

Verschil is significant voor $* p<0.05, * * p<0,01$ of $* * * p<0,001$

Tabel B3.79 Verschil in ondernomen activiteiten voor natuur naar etniciteit

$\begin{array}{lccc}\text { Activiteit } & \begin{array}{c}\text { Autochtonen en } \\ \text { Westerse } \\ \text { allochtonen }\end{array} & \begin{array}{c}\text { Niet-westerse } \\ \text { allochtonen }\end{array} & \text { sign } \\ \text { Onderhoud } & 7 \% & 4 \% & * * \\ \text { Aanleg streekeigen } & 11 \% & 7 \% & * * \\ \text { Plaatsen nestkastjes } & 33 \% & 19 \% & * * \\ \text { Weidevogelbescherming } & 2 \% & 0 \% & * * * \\ \text { Inventarisatie } & 8 \% & 3 \% & * * \\ \text { Afval } & 29 \% & 21 \% & * * \\ \text { Anders } & 2 \% & 1 \% & * * *\end{array}$

Verschil is significant voor $* p<0.05, * * p<0,01$ of $* * * p<0,001$

Tabel B3.80 Verschil in ondernomen activiteiten voor natuur naar stedelijkheid

$\begin{array}{lccc}\text { Activiteit } & 4 \text { grote steden } & \text { Overig Nederland } & \text { sign } \\ \text { Aanleg streekeigen } & 7 \% & 11 \% & * * \\ \text { Plaatsen nestkastjes } & 17 \% & 33 \% & * * * \\ \text { Inventarisatie } & 2 \% & 8 \% & * * * \\ \text { Sociale activiteiten } & 8 \% & 5 \% & * \\ \text { Geen van deze } & 51 \% & 43 \% & * * \\ \text { Verschil is significant voor } * p<0.05 * * p<0,01 \text { of } * * * p<0,001 & & \end{array}$

Verschil is significant voor $* p<0.05, * * p<0,01$ of $* * * p<0,001$ 


\section{Enquêtevraag $7^{8}$}

Tabel B3.81 Verschil in lidmaatschap natuurorganisatie naar geslacht

Wel/geen lid Man Vrouw sign

Verschil is significant voor $* p<0.05, * * p<0,01$ of $* * * p<0,001$

Tabel B3.82 Verschil in lidmaatschap natuurorganisatie naar leeftijd

\begin{tabular}{|c|c|c|c|c|}
\hline Wel/geen lid & 15 tot 35 jaar & 35 tot 55 jaar & 55 tot 75 jaar & sign \\
\hline Lid & $12 \%$ & $25 \%$ & $34 \%$ & $* * *$ \\
\hline
\end{tabular}

Verschil is significant voor $* p<0.05, * * p<0,01$ of $* * * p<0,001$

Tabel B3.83 Verschil in lidmaatschap natuurorganisatie naar opleidingsniveau

$\begin{array}{lcccc}\text { Wel/geen lid } & \text { Laag } & \text { Midden } & \text { Hoog } & \text { sign } \\ \text { Lid } & 18 \% & 24 \% & 26 \% & * *\end{array}$

Verschil is significant voor $* p<0.05, * * p<0,01$ of $* * * p<0,001$

Tabel B3.84 Verschil in lidmaatschap natuurorganisatie naar etniciteit

\begin{tabular}{|c|c|c|c|}
\hline Wel/geen lid & $\begin{array}{c}\text { Autochtonen en } \\
\text { Westerse } \\
\text { allochtonen }\end{array}$ & $\begin{array}{c}\text { Niet-westerse } \\
\text { allochtonen }\end{array}$ & sign \\
\hline Lid & $25 \%$ & $16 \%$ & $* * *$ \\
\hline
\end{tabular}

Verschil is significant voor $* p<0.05, * * p<0,01$ of $* * * p<0,001$

Tabel B3.85 Verschil in lidmaatschap natuurorganisatie naar stedelijkheid

Wel/geen lid 4 grote steden Overig Nederland sign

Verschil is significant voor $* p<0.05, * * p<0,01$ of $* * * p<0,001$

\section{Enquêtevraag 8}

Tabel B3.86 Verschil in financieel bijgedragen aan natuur naar geslacht

$\begin{array}{lccc}\text { Type bijdrage } & \text { Man } & \text { Vrouw } & \text { sign } \\ \text { Certificaat } & 2 \% & 1 \% & * *\end{array}$

Verschil is significant voor $* p<0.05, * * p<0,01$ of $* * * p<0,001$

Tabel B3.87 Verschil in financieel bijgedragen aan natuur naar leeftijd

$\begin{array}{lcccc}\text { Type bijdrage } & 15 \text { tot } 35 \text { jaar } & 35 \text { tot } 55 \text { jaar } & 55 \text { tot } 75 \text { jaar } & \text { sign } \\ \text { Bedrag gegeven } & 10 \% & 22 \% & 28 \% & * * * \\ \text { Geen van deze } & 63 \% & 55 \% & 49 \% & * * *\end{array}$

Verschil is significant voor $* p<0.05, * * p<0,01$ of $* * * p<0,001$

Tabel B3.88 Verschil in financieel bijgedragen aan natuur naar opleidingsniveau

$\begin{array}{lcccc}\text { Type bijdrage } & \text { Laag } & \text { Midden } & \text { Hoog } & \text { sign } \\ \text { Bedrag gegeven } & 16 \% & 19 \% & 24 \% & * * \\ \text { Groen belegd } & 2 \% & 4 \% & 4 \% & * \\ \text { Producten gekocht } & 23 \% & 27 \% & 37 \% & * * * \\ \text { Geen van deze } & 61 \% & 58 \% & 50 \% & * * *\end{array}$

Verschil is significant voor $* p<0.05, * * p<0,01$ of $* * * p<0,001$

\footnotetext{
${ }^{8}$ alleen getoetst voor wel/niet lid zijn: v07_1
}

110 | wOt-technical report 102 
Tabel B3.89 Verschil in financieel bijgedragen aan natuur naar etniciteit

$\begin{array}{lccc}\text { Type bijdrage } & \begin{array}{c}\text { Autochtonen en } \\ \text { Westerse } \\ \text { allochtonen }\end{array} & \begin{array}{c}\text { Niet-westerse } \\ \text { allochtonen }\end{array} \\ \text { Bedrag gegeven } & 21 \% & 14 \% & * * \\ \text { Groen belegd } & 4 \% & 2 \% & * * \\ \text { Producten gekocht } & 30 \% & 24 \% & * \\ \text { Anders } & 3 \% & 1 \% & * * * \\ \text { Geen van deze } & 54 \% & 67 \% & * * *\end{array}$

Verschil is significant voor $* p<0.05, * * p<0,01$ of $* * * p<0,001$

Tabel B3.90 Verschil in financieel bijgedragen aan natuur naar stedelijkheid

$\begin{array}{lccc}\text { Type bijdrage } & 4 \text { grote steden } & \text { Overig Nederland } & \text { sign } \\ \text { Groen belegd } & 6 \% & 3 \% & * \\ \text { Certificaat } & 3 \% & 1 \% & * \\ \text { Anders } & 2 \% & 3 \% & *\end{array}$

Verschil is significant voor $* p<0.05, * * p<0,01$ of $* * * p<0,001$

\section{Enquêtevraag 17}

Tabel B3.91 Verschil in ondernomen activiteiten voor plannen voor natuur naar geslacht

$\begin{array}{lccc}\text { Activiteit } & \text { Man } & \text { Vrouw } & \text { sign } \\ \text { Actie gevoerd } & 3 \% & 2 \% & * * * \\ \text { Naar inspraak } & 8 \% & 3 \% & * * \\ \text { Brieven } & 2 \% & 1 \% & * *\end{array}$

Verschil is significant voor $* p<0.05, * * p<0,01$ of $* * * p<0,001$

Tabel B3.92 Verschil in ondernomen activiteiten voor plannen voor natuur naar leeftijd

\begin{tabular}{|c|c|c|c|c|}
\hline Activiteit & 15 tot 35 jaar & 35 tot 55 jaar & 55 tot 75 jaar & sign \\
\hline Buurtoverleg & $2 \%$ & $4 \%$ & $9 \%$ & $* * *$ \\
\hline Naar inspraak & $4 \%$ & $5 \%$ & $8 \%$ & $* *$ \\
\hline Brieven & $3 \%$ & $0 \%$ & $1 \%$ & $* * *$ \\
\hline Handtekening & $10 \%$ & $14 \%$ & $16 \%$ & $* *$ \\
\hline Protestmail & $2 \%$ & $4 \%$ & $4 \%$ & $*$ \\
\hline In mijn stemkeuze & $16 \%$ & $17 \%$ & $22 \%$ & $* *$ \\
\hline Anders & $0 \%$ & $2 \%$ & $2 \%$ & $* *$ \\
\hline Geen van deze & $71 \%$ & $70 \%$ & $61 \%$ & $* * *$ \\
\hline
\end{tabular}

Verschil is significant voor $* p<0.05, * * p<0,01$ of $* * * p<0,001$

Tabel B3.93 Verschil in ondernomen activiteiten voor plannen voor natuur naar opleidingsniveau

$\begin{array}{lcccc}\text { Activiteit } & \text { Laag } & \text { Midden } & \text { Hoog } & \text { sign } \\ \text { Brieven } & 1 \% & 1 \% & 2 \% & * \\ \text { In mijn stemkeuze } & 11 \% & 16 \% & 24 \% & * * * \\ \text { Geen van deze } & 71 \% & 69 \% & 63 \% & * * \\ \text { Ver } & & & \end{array}$

Verschil is significant voor $* p<0.05, * * p<0,01$ of $* * * p<0,001$

Tabel B3.94 Verschil in ondernomen activiteiten voor plannen voor natuur naar etniciteit

\begin{tabular}{|c|c|c|c|}
\hline Activiteit & $\begin{array}{c}\text { Autochtonen en } \\
\text { Westerse } \\
\text { allochtonen }\end{array}$ & $\begin{array}{c}\text { Niet-westerse } \\
\text { allochtonen }\end{array}$ & sign \\
\hline Brieven & $1 \%$ & $4 \%$ & $*$ \\
\hline Protestmail & $4 \%$ & $1 \%$ & $* *$ \\
\hline In mijn stemkeuze & $19 \%$ & $13 \%$ & $* *$ \\
\hline Anders & $1 \%$ & $0 \%$ & * \\
\hline
\end{tabular}

Verschil is significant voor $* p<0.05, * * p<0,01$ of $* * * p<0,001$ 
Tabel B3.95 Verschil in ondernomen activiteiten voor plannen voor natuur naar stedelijkheid

$\begin{array}{lccc}\text { Activiteit } & 4 \text { grote steden } & \text { Overig Nederland } & \text { sign } \\ \text { Brieven } & 4 \% & 1 \% & * * \\ \text { Protestmail } & 6 \% & 3 \% & * \\ \text { In mijn stemkeuze } & 22 \% & 17 \% & * \\ \text { Geen van deze } & 61 \% & 68 \% & *\end{array}$

Verschil is significant voor $* p<0.05, * * p<0,01$ of $* * * p<0,001$

\section{Enquêtevraag 18}

Tabel B3.96 Verschil in kennen van groene burgerinitiatieven naar geslacht

$\begin{array}{lccc}\text { Reden } & \text { Man } & \text { Vrouw } & \text { sign } \\ \text { Ja } & 23 \% & 18 \% & * * * \\ \text { Nee } & 62 \% & 60 \% & 22 \%\end{array}$

Verschil is significant voor $* p<0.05, * * p<0,01$ of $* * * p<0,001$

Tabel B3.97 Verschil in kennen van groene burgerinitiatieven naar leeftijd

\begin{tabular}{|c|c|c|c|c|}
\hline Antwoord & 15 tot 35 jaar & 35 tot 55 jaar & 55 tot 75 jaar & sign \\
\hline $\mathrm{Ja}$ & $16 \%$ & $19 \%$ & $26 \%$ & $* * *$ \\
\hline Nee & $68 \%$ & $62 \%$ & $52 \%$ & \\
\hline Weet ik niet & $16 \%$ & $19 \%$ & $22 \%$ & \\
\hline
\end{tabular}

Verschil is significant voor $* p<0.05, * * p<0,01$ of $* * * p<0,001$

Tabel B3.98 Verschil in kennen van groene burgerinitiatieven naar opleidingsniveau

$\begin{array}{lcccc}\text { Antwoord } & \text { Laag } & \text { Midden } & \text { Hoog } & \text { sign } \\ \text { Ja } & 19 \% & 18 \% & 24 \% & * * * \\ \text { Nee } & 53 \% & 61 \% & 66 \% & \\ \text { Weet ik niet } & 28 \% & 21 \% & 11 \% & \end{array}$

Verschil is significant voor $* p<0.05, * * p<0,01$ of $* * * p<0,001$

Tabel B3.99 Verschil in kennen van groene burgerinitiatieven naar etniciteit

$\begin{array}{cc}\text { Reden } & \text { Niet-westerse } \\ \text { Westerse } & \text { allochtonen } \\ \text { allochtonen } & \end{array}$

Verschil is significant voor $* p<0.05, * * p<0,01$ of $* * * p<0,001$

Tabel B3.100 Verschil in kennen van groene burgerinitiatieven naar stedelijkheid

Reden 4 grote steden Overig Nederland sign

Verschil is significant voor $* p<0.05, * * p<0,01$ of $* * * p<0,001$

\section{Enquêtevraag 18A}

Tabel B3.101 Verschil in soort groen burgerinitiatief naar geslacht

$\begin{array}{llcc}\text { Soort } & \text { Man } & \text { Vrouw } & \text { sign } \\ \text { Realisatie } & 48 \% & 37 \% & *\end{array}$

Verschil is significant voor $* p<0.05, * * p<0,01$ of $* * * p<0,001$

Tabel B3.102 Verschil in soort groen burgerinitiatief naar leeftijd

$\begin{array}{lcccc}\text { Soort } & 15 \text { tot } 35 \text { jaar } & 35 \text { tot } 55 \text { jaar } & 55 \text { tot } 75 \text { jaar } & \text { sign } \\ \text { Actievoeren } & 29 \% & 24 \% & 13 \% & * * \\ \text { Educatieve activiteiten } & 21 \% & 18 \% & 29 \% & *\end{array}$

Verschil is significant voor $* p<0.05, * * p<0,01$ of $* * * p<0,001$ 
Tabel B3.103 Verschil in soort groen burgerinitiatief naar opleidingsniveau

$\begin{array}{lcccc}\text { Soort } & \text { Laag } & \text { Midden } & \text { Hoog } & \text { sign } \\ \text { Realisatie } & 37 \% & 39 \% & 50 \% & * \\ \text { Verschil is significant voor } * \mathrm{p}<0.05, * * p<0,01 \text { of } * * * p<0,001 & & \end{array}$

Tabel B3.104 Verschil in soort groen burgerinitiatief naar etniciteit

$\begin{array}{cc}\text { Autochtonen en } & \text { Niet-westerse } \\ \text { Westerse } & \text { allochtonen } \\ \text { allochtonen } & \end{array}$

Verschil is significant voor $* p<0.05, * * p<0,01$ of $* * * p<0,001$

Tabel B3.105 Verschil in soort groen burgerinitiatief naar stedelijkheid

$\begin{array}{lccc} & & & \text { sign } \\ \text { Soort } & 4 \text { grote steden } & \text { Overig Nederland } & * * \\ \text { Beheer } & 34 \% & 56 \% & * * \\ \text { Actievoeren } & 38 \% & 18 \% & * * \\ \text { Verschil is significant voor } * \mathrm{p}<0.05, * * \mathrm{p}<0,01 \text { of } * * * \mathrm{p}<0,001 & & \end{array}$

\section{Enquêtevraag 18B}

Tabel B3.106 Verschil in type betrokkenheid bij groen burgerinitiatief naar geslacht

Type betrokkenheid Man Vrouw sign

Verschil is significant voor $* p<0.05, * * p<0,01$ of $* * * p<0,001$

Tabel B3.107 Verschil in type betrokkenheid bij groen burgerinitiatief naar leeftijd

\begin{tabular}{|c|c|c|c|c|}
\hline Type betrokkenheid & 15 tot 35 jaar & 35 tot 55 jaar & 55 tot 75 jaar & sign \\
\hline Ik ontvang informatie & $34 \%$ & $43 \%$ & $50 \%$ & $*$ \\
\hline
\end{tabular}

Tabel B3.108 Verschil in type betrokkenheid bij groen burgerinitiatief naar opleidingsniveau

Type betrokkenheid Laag Midden Hoog sign

Verschil is significant voor $* p<0.05, * * p<0,01$ of $* * * p<0,001$

Tabel B3.109 Verschil in type betrokkenheid bij groen burgerinitiatief naar etniciteit

\begin{tabular}{|c|c|c|c|}
\hline Type betrokkenheid & $\begin{array}{c}\text { Autochtonen en } \\
\text { Westerse } \\
\text { allochtonen }\end{array}$ & $\begin{array}{c}\text { Niet-westerse } \\
\text { allochtonen }\end{array}$ & sign \\
\hline Ik ben (één van de) & 5 & 23 & $* *$ \\
\hline Ik ontvang informatie & 45 & 29 & $*$ \\
\hline Ik werk mee & 18 & 9 & $*$ \\
\hline
\end{tabular}

Verschil is significant voor $* p<0.05, * * p<0,01$ of $* * * p<0,001$

Tabel B3.110 Verschil in type betrokkenheid bij groen burgerinitiatief naar stedelijkheid

Type betrokkenheid 4 grote steden Overig Nederland sign

Verschil is significant voor $* p<0.05, * * p<0,01$ of $* * * p<0,001$ 



\section{Bijlage 4 Tabellen met significante verschillen op basis van verschuivingen in de tijd}

\section{BEHOREND BIJ HOOFDSTUK 4}

\section{Enquêtevraag 12}

Tabel B4.1 Verschil in beoordeling van probleembesef omtrent belang natuur, percentage (helemaal) niet eens met uitspraken naar jaargang enquête

\begin{tabular}{|c|c|c|c|c|c|c|c|}
\hline Stelling & 2006 & 2013 & 2017 & sign & $\begin{array}{c}2006- \\
2013\end{array}$ & $\begin{array}{r}2006- \\
2017\end{array}$ & $\begin{array}{r}2013- \\
2017\end{array}$ \\
\hline Al die aandacht $\ldots$ is niet ${ }^{1}$ & $68 \%$ & $66 \%$ & $71 \%$ & $*$ & n.s. & $*$ & $*$ \\
\hline We maken ons niet ${ }^{1}$ & $48 \%$ & $48 \%$ & $60 \%$ & $* * *$ & n.s. & $* * *$ & $* * *$ \\
\hline De overheid & $39 \%$ & $39 \%$ & $47 \%$ & $* * *$ & n.s. & $* * *$ & $* * *$ \\
\hline
\end{tabular}

Verschil is significant voor $* p<0.05, * * p<0,01$ of $* * * p<0,001$

${ }^{1}=$ Gecorrigeerd voor gespiegelde oorspronkelijke vraag

\section{Enquêtevraag 11}

Tabel B4.2 Verschil in mening (schaal 1-4; 4=pro-natuur) over dilemma's economie-natuur naar jaargang enquête

\begin{tabular}{|c|c|c|c|c|c|c|c|}
\hline Dilemma & 2006 & 2013 & 2017 & sign & $\begin{array}{r}2006- \\
2013\end{array}$ & $\begin{array}{c}2006- \\
2017\end{array}$ & $\begin{array}{r}2013- \\
2017\end{array}$ \\
\hline Winkels of groen ${ }^{1}$ & 3,22 & 3,09 & 3,18 & $* * *$ & $* * *$ & n.s. & * \\
\hline Parkeren of veldjes & 2,91 & 2,98 & 3,01 & $*$ & n.s. & * & n.s. \\
\hline Wegen of rekeningrijden ${ }^{1}$ & 2,66 & 2,44 & 2,61 & $* * *$ & $* * *$ & n.s. & $* * *$ \\
\hline Woningen of natuur & 2,89 & 2,99 & 2,87 & $* * *$ & $* * *$ & n.s. & $* * *$ \\
\hline Groot- of kleinsch. Lb ${ }^{1}$ & 2,46 & 2,63 & 2,65 & $* *$ & $*$ & $* * *$ & n.s. \\
\hline
\end{tabular}

Verschil is significant voor $* p<0.05, * * p<0,01$ of $* * * p<0,001$

$1=$ gemiddelde is gecorrigeerd vanwege gespiegelde oorspronkelijke vraag

\section{Enquêtevraag 13}

Tabel B4.3 Verschil in beoordeling van de omgang met natuur, percentage (helemaal) mee eens, naar jaargang enquête

\begin{tabular}{lllll:|c|c|c|c|c|c|c} 
Stelling & 2006 & 2013 & 2017 & sign & $2006-$ & $2006-$ & $2013-$ \\
Dode bomen & & & & 2013 & 2017 & 2017 \\
Hoe langer & $26 \%$ & $21 \%$ & $29 \%$ & $* * *$ & $*$ & n.s. & $* * *$ \\
In de natuur & $57 \%$ & $58 \%$ & $62 \%$ & $*$ & n.s. & $*$ & $*$ \\
Het in koude & $68 \%$ & $61 \%$ & $78 \%$ & $* * *$ & $* * *$ & $* * *$ & $* * *$ \\
Bomen en struiken & $19 \%$ & $23 \%$ & $26 \%$ & $* * *$ & $*$ & $* * *$ & n.s. \\
Om een gebied & $46 \%$ & $58 \%$ & $54 \%$ & $* * *$ & $* * *$ & $* * *$ & n.s. \\
Ik vind het & $23 \%$ & $28 \%$ & $33 \%$ & $* * *$ & $*$ & $* * *$ & $*$
\end{tabular}

Verschil is significant voor $* p<0.05, * * p<0,01$ of $* * * p<0,001$

Enquêtevragen 2 en 3

Tabel B4.4 Verschil in beoordeling van hoeveelheid natuur als (ruim) voldoende naar jaargang enquête

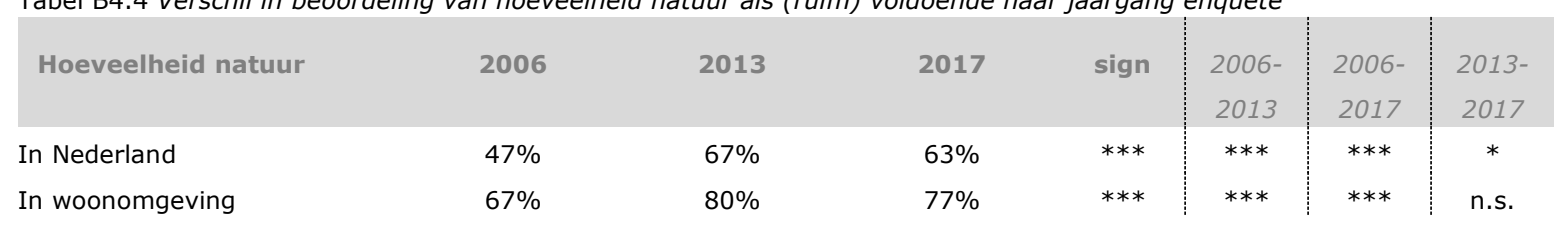

Verschil is significant voor $* p<0.05, * * p<0,01$ of $* * * p<0,001$ 


\section{BEHOREND BIJ HOOFDSTUK 5}

\section{Enquêtevraag 1}

Tabel B4.5 Verschil in mening over prioritaire overheidsonderwerpen naar jaargang enquête

\begin{tabular}{|c|c|c|c|c|c|c|c|}
\hline Onderwerp & 2006 & 2013 & 2017 & sign & $\begin{array}{l}2006- \\
2013\end{array}$ & $\begin{array}{c}2006- \\
2017\end{array}$ & $\begin{array}{r}2013- \\
2017\end{array}$ \\
\hline Misdaad en terrorisme & $48 \%$ & $40 \%$ & $44 \%$ & $* * *$ & $* * *$ & $*$ & $*$ \\
\hline Immigratie en & $9 \%$ & $5 \%$ & $24 \%$ & $* * *$ & $* *$ & $* * *$ & $* * *$ \\
\hline Sociale zekerheid & $50 \%$ & $52 \%$ & $41 \%$ & $* * *$ & n.s. & $* * *$ & $* * *$ \\
\hline Natuur & $21 \%$ & $19 \%$ & $14 \%$ & $* * *$ & n.s. & $* * *$ & $* *$ \\
\hline Onderwijs & $57 \%$ & $60 \%$ & $51 \%$ & $* * *$ & n.s. & $* * *$ & $* * *$ \\
\hline Werkgelegenheid & $47 \%$ & $72 \%$ & $44 \%$ & $* * *$ & $* * *$ & n.s. & $* * *$ \\
\hline
\end{tabular}

Verschil is significant voor $* p<0.05, * * p<0,01$ of $* * * p<0,001$

\section{Enquêtevraag 9}

Tabel B4.6 Verschil in beoordeling van beschermingsmaatregelen als (zeer) belangrijk naar jaargang enquête

\begin{tabular}{|c|c|c|c|c|c|c|c|}
\hline Maatregel & 2006 & 2013 & 2017 & sign & $\begin{array}{c}2006- \\
2013\end{array}$ & $\begin{array}{c}2006- \\
2017\end{array}$ & $\begin{array}{r}2013- \\
2017\end{array}$ \\
\hline Verbinden & $58 \%$ & $64 \%$ & $70 \%$ & $* * *$ & $* *$ & $* * *$ & $* *$ \\
\hline Beschermen zeldzame & $88 \%$ & $86 \%$ & $92 \%$ & $* * *$ & n.s. & $* * *$ & $* * *$ \\
\hline Meer natuur in stad & $75 \%$ & $75 \%$ & $80 \%$ & $* * *$ & n.s. & $* *$ & $*$ \\
\hline Meer natuur platteland & $60 \%$ & $57 \%$ & $65 \%$ & $* * *$ & n.s. & $*$ & $* * *$ \\
\hline Meer natuureducatie & $89 \%$ & $79 \%$ & $84 \%$ & $* * *$ & $* * *$ & $* * *$ & $* * *$ \\
\hline
\end{tabular}

Verschil is significant voor $* p<0.05, * * p<0,01$ of $* * * p<0,001$

BEHOREND BIJ HOOFDSTUK 6

\section{Enquêtevraag 5}

Tabel B4.7 Verschil in bezoek natuur (schaal 1-5) naar jaargang enquête

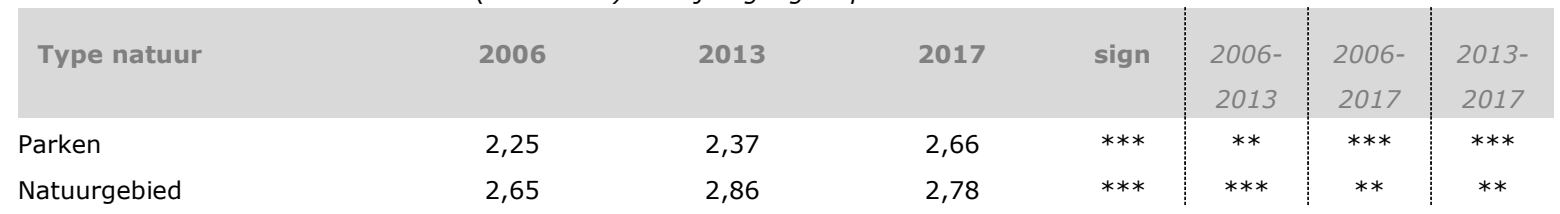

Verschil is significant voor $* p<0.05, * * p<0,01$ of $* * *<0,001$

\section{Enquêtevraag 6}

Tabel B4.8 Verschil in gebruik informatiebronnen naar jaargang enquête

\begin{tabular}{|c|c|c|c|c|c|c|c|}
\hline Tijdschrift & $33 \%$ & $31 \%$ & $26 \%$ & $* * *$ & n.s. & $* * *$ & $* * *$ \\
\hline Internet & $28 \%$ & $37 \%$ & $33 \%$ & $* * *$ & $* * *$ & $*$ & $*$ \\
\hline Sociale media & n.v.t. & $7 \%$ & $13 \%$ & $* * *$ & & & \\
\hline Geen van deze & $10 \%$ & $20 \%$ & $24 \%$ & $* * *$ & $* * *$ & $* * *$ & $*$ \\
\hline
\end{tabular}

Verschil is significant voor $* p<0.05, * * p<0,01$ of $* * * p<0,001$ 


\section{Enquêtevraag 16}

Tabel B4.9 Verschil in ondernomen activiteiten voor natuur naar jaargang enquête

\begin{tabular}{|c|c|c|c|c|c|c|c|}
\hline Informatiebron & 2006 & 2013 & 2017 & sign & $\begin{array}{l}2006- \\
2013\end{array}$ & $\begin{array}{r}2006- \\
2017\end{array}$ & $\begin{array}{r}2013- \\
2017\end{array}$ \\
\hline Aanleg streekeigen & $17 \%$ & $19 \%$ & $11 \%$ & $* * *$ & n.s. & $* * *$ & $* * *$ \\
\hline Plaatsen nestkastjes & $32 \%$ & $37 \%$ & $31 \%$ & $* *$ & $*$ & n.s. & $* *$ \\
\hline Afval van anderen & $18 \%$ & $20 \%$ & $28 \%$ & $* * *$ & n.s. & $* * *$ & $* * *$ \\
\hline Anders & $1 \%$ & $3 \%$ & $2 \%$ & $*$ & $*$ & n.s. & n.s. \\
\hline Geen van deze & $50 \%$ & $43 \%$ & $44 \%$ & $* * *$ & $* *$ & $* *$ & n.s. \\
\hline
\end{tabular}

Verschil is significant voor $* p<0.05, * * p<0,01$ of $* * * p<0,001$

\section{Enquêtevraag 8}

Tabel B4.10 Verschil in financieel bijgedragen aan natuur naar jaargang enquête

\begin{tabular}{|c|c|c|c|c|c|c|c|}
\hline Producten gekocht & $38 \%$ & $41 \%$ & $30 \%$ & $* * *$ & n.s. & $* * *$ & $* * *$ \\
\hline Aan een adoptieactie & $3 \%$ & $4 \%$ & $2 \%$ & $*$ & n.s. & n.s. & $*$ \\
\hline
\end{tabular}

Verschil is significant voor $* p<0.05, * * p<0,01$ of $* * * p<0,001$

\section{Enquêtevraag 17}

Tabel B4.11 Verschil in ondernomen activiteiten voor plannen voor natuur naar jaargang enquête

\begin{tabular}{lcccc|} 
Activiteit & 2006 & 2013 & 2017 & sign \\
Actie gevoerd & n.v.t. & $1 \%$ & $3 \%$ & $*$ \\
Geen van deze & n.v.t. & $79 \%$ & $67 \%$ & $* * *$
\end{tabular}

Verschil is significant voor $* p<0.05, * * p<0,01$ of $* * * p<0,001$

\section{Enquêtevraag 18}

Tabel B4.12 Verschil in kennen van groene burgerinitiatieven naar jaargang enquête

$\begin{array}{lllll}\text { Antwoord } & 2006 & 2013 & 2017 & \text { sign } \\ \text { Ja } & \text { n.v.t. } & 18 \% & 20 \% & * * \\ \text { Nee } & & 67 \% & 61 \% & \\ \text { Weet ik niet } & & 15 \% & 19 \%\end{array}$

Verschil is significant voor $* p<0.05, * * p<0,01$ of $* * * p<0,001$

\section{Enquêtevraag $18 b$}

Tabel B4.13 Verschil in betrokkenheid bij groene burgerinitiatieven naar jaargang enquête

$\begin{array}{lcccc}\text { Antwoord } & 2006 & 2013 & 2017 & \text { sign } \\ \text { Initiatiefnemer } & \text { n.v.t. } & 2 \% & 7 \% & * \\ \text { Ontvang informatie } & \text { n.v.t. } & 31 \% & 44 \% & * * * \\ \text { Geen van deze } & \text { n.v.t. } & 51 \% & 39 \% & * * *\end{array}$

Verschil is significant voor $* p<0.05, * * p<0,01$ of $* * * p<0,001$ 



\section{Bijlage 5 Segmentatie burgerbetrokken- heid bij natuur}

In deze bijlage wordt uitgelegd hoe de segmentatie van de Nederlandse bevolking voor betrokkenheid bij natuur tot stand is gekomen.

\section{Stap 1.}

In tabel B5.1 staan de zes vormen van burgerbetrokkenheid: er is onderscheid gemaakt tussen gebruiker, beschermer en beslisser en in de mate van betrokkenheid (actief en passief). Per domein zijn er verschillende indicatoren. Deze indicatoren zijn gebaseerd op 7 enquêtevragen. Elke vraag is uitgewerkt als één aparte indicator, met uitzondering van 2 vragen:

- De vraag naar activiteiten voor natuur en landschap is uitgewerkt naar 2 indicatoren. De antwoordcategorieën stemgedrag en handtekening zetten vormen 1 indicator en de $2^{\mathrm{e}}$ indicator is gebaseerd op de andere antwoordcategorieën van deze vraag.

- Ook de vraag naar betrokkenheid bij burgerinitiatieven is uitgewerkt naar 2 indicatoren. De eerste indicator is gebaseerd op de antwoordcategorie ik ben een van de initiatiefnemers; de tweede indicator is gebaseerd op de antwoordcategorie ik werk mee aan de uitvoering van het initiatief. Besloten is om deze laatste niet onder beslisser te plaatsen, maar onder beschermer omdat meewerken in de uitvoering een activiteit is gericht op bescherming. De antwoordcategorie ik ontvang informatie over het initiatief is buiten beschouwing gelaten voor de segmentatie, omdat dit geen goede indicator is in relatie tot beslissen.

Tabel B5.1 Indicatoren voor vormen van burgerbetrokkenheid bij natuur.

\begin{tabular}{|c|c|c|c|}
\hline $\begin{array}{l}\text { Mate van } \\
\text { betrokkenheid }\end{array}$ & Gebruiker & Beschermer & Beslisser \\
\hline Actief & $\begin{array}{l}\text { Bezoek aan groen in de } \\
\text { stad, platteland, natuur- } \\
\text { gebied }\end{array}$ & $\begin{array}{l}\text { Activiteiten voor natuur- } \\
\text { en landschap } \\
\text { Actief in burgerinitiatief: } \\
\text { ik werk mee aan } \\
\text { uitvoering burgerinitiatief }\end{array}$ & $\begin{array}{l}\text { Activiteiten voor natuur- } \\
\text { en landschap gericht op } \\
\text { beïnvloeding van besluit- } \\
\text { vorming (minus } \\
\text { stemgedrag en } \\
\text { handtekening) } \\
\text { Actief in burgerinitiatief: } \\
\text { ik ben een van de } \\
\text { initiatiefnemers }\end{array}$ \\
\hline Passief & $\begin{array}{l}\text { Gebruik informatie- } \\
\text { bronnen over natuur }\end{array}$ & $\begin{array}{l}\text { Lidmaatschap } \\
\text { natuurorganisaties } \\
\text { Financiële bijdrage voor } \\
\text { natuur }\end{array}$ & $\begin{array}{l}\text { Activiteiten voor natuur- } \\
\text { en landschap gericht op } \\
\text { beïnvloeding van besluit- } \\
\text { vorming: groen stemmen } \\
\text { en handtekening zetten }\end{array}$ \\
\hline
\end{tabular}

\section{Stap 2}

Om de verschillende vormen van burgerbetrokkenheid te vergelijken hebben we voor de zes vormen van burgerbetrokkenheid alle indicatoren tot één indicator teruggebracht en komen dus zo tot 6 indicatoren:

1. De indicator 'informatiebronnen' hoeft niet te worden gegroepeerd omdat het al om één indicator gaat.

2. De drie indicatoren 'bezoek aan groen in de stad, aan platteland en aan natuurgebieden' zijn teruggebracht tot één indicator 'natuurbezoek'.

3. De indicator 'lidmaatschap van natuurorganisaties' is toegevoegd aan de indicator 'financiële bijdrage aan natuurbescherming'.

4. De indicator 'actief in burgerinitiatief als uitvoerder' is toegevoegd aan de indicator 'activiteiten voor natuur- en landschapsbeheer.

5. De indicator 'actief in burgerinitiatief als initiatiefnemer' is toegevoegd aan de indicator 'activiteiten voor gericht op beïnvloeding besluitvorming'.

6. De indicatoren 'handtekening zetten' en 'bij stemkeuze het onderwerp natuur mee laten wegen' (van de indicator 'activiteiten voor besluitvorming') zijn samengevoegd en vormen een aparte categorie. 
Elk van deze zes indicatoren (met uitzondering van handtekening zetten/stemkeuze) heeft vier categorieën van mate van betrokkenheid:

1. 'niet betrokken' ( 0 activiteiten)

2. 'weinig betrokken' ( 1 activiteit)

3. 'redelijk betrokken' ( 2 tot 3 activiteiten)

4. 'zeer betrokken' (4 activiteiten of meer)

Een uitzondering is de indicator 'handtekening zetten/stemgedrag'. Deze indicator heeft 3 categorieën. De indicator natuurbezoek kent andere categorieën 'niet betrokken' (nooit/zelden), 'weinig betrokken' (zo nu en dan), 'actief' (regelmatig), 'zeer betrokken' (vaak of zeer vaak).

Tabel B5.2 Uitwerking indicatoren

\begin{tabular}{|c|c|c|c|}
\hline & $\begin{array}{l}\text { Betrokkenheid } \\
\text { bij natuur }\end{array}$ & Variabele naam en values & Bewerking \\
\hline $\begin{array}{l}\text { Gebruiker } \\
\text { actief }\end{array}$ & $\begin{array}{l}\text { Bezoek aan } \\
\text { parken en groen } \\
\text { in de stad, } \\
\text { platteland, } \\
\text { natuurgebied } \\
\text { (bos, heide, } \\
\text { duinen, meren } \\
\text { en plassen, etc. }\end{array}$ & $\begin{array}{l}\text { v80_1 parken en groen stad } \\
\text { v80_2 platteland } \\
\text { v80_3 natuurgebieden } \\
\text { Values: } 1=\text { (bijna) nooit, } 2=\text { een enkele } \\
\text { keer, } 3=\text { regelmatig, } 4=\text { vaak, } 5=\text { zeer } \\
\text { vaak/(bijna) dagelijks }\end{array}$ & $\begin{array}{l}\text { Zelden/nooit: } 3 x \text { values } 1 \text { of } 2 \\
\text { bij elkaar opgeteld } \\
\text { (zeer) Vaak: tenminste } 2 x \\
\text { values } 4 \text { of } 5 \\
\text { Zo nu en dan: } 2 \text { x values } 1 \text { of } 2 \\
\text { and } 1 x \text { regelmatig } \\
\text { Variabele: groenbezoek } \\
\text { Values: } 1=\text { zelden/nooit, } 2=\text { zo } \\
\text { nu en dan, } 3=\text { regelmatig, } \\
4=(z e e r) v a a k\end{array}$ \\
\hline $\begin{array}{l}\text { Gebruiker } \\
\text { passief }\end{array}$ & $\begin{array}{l}\text { Informatiebronn } \\
\text { en gericht op } \\
\text { media }\end{array}$ & $\begin{array}{l}\text { V100_1 televisieprogramma of film over } \\
\text { natuur bekeken } \\
\text { V100_2 tijdschrift/boek/artikel over natuur } \\
\text { gelezen } \\
\text { V100_7 internet over natuur geraadpleegd } \\
\text { V100_10 webcam(s) over natuur bekeken } \\
\text { V100_11 social media (twitter, facebook) } \\
\text { over natuur gevolgd } \\
\text { V100_12 anders, nl. } \\
\text { V100_13 apps over natuur gebruikt } \\
\text { V100_9 (geen van deze) } \\
\text { Values } 0 \text { = not mentioned, } 1=\text { mentioned }\end{array}$ & $\begin{array}{l}\text { Aantal keren dat een activiteit } \\
\text { is genoemd opgeteld. } \\
\text { Variabele: infogebruik } \\
\text { Values: } 1=\text { niets ( } 0 \\
\text { activiteiten), } 2=\text { weinig ( } 1 \\
\text { activiteit), } 3=\text { redelijk wat ( } 2 \\
\text { tot } 3 \text { activiteiten), } 4=\text { (zeer) } \\
\text { veel ( } 4 \text { activiteiten of meer) }\end{array}$ \\
\hline \multirow[t]{2}{*}{$\begin{array}{l}\text { Beschermer } \\
\text { actief }\end{array}$} & $\begin{array}{l}\text { Activiteiten voor } \\
\text { natuur- en } \\
\text { landschap }\end{array}$ & $\begin{array}{l}\text { V16_1 onderhoud van natuur of landschap } \\
\text { (bomen snoeien \& knotten, bermbeheer, } \\
\text { poelen schonen, houtwallen afzetten, etc.) } \\
\text { V16_2 aanleg van streekeigen beplanting bij } \\
\text { mijn huis } \\
\text { V16_3 plaatsen van nestkastjes, } \\
\text { voederplankjes bij mijn huis } \\
\text { V16_4 weidevogelbescherming } \\
\text { V16_5 inventarisatie van dier- of } \\
\text { plantensoorten, natuurstudie } \\
\text { V16_6 geven van natuureducatie, lezingen } \\
\text { en rondleidingen } \\
\text { V16_7 sociale activiteiten in de natuur } \\
\text { organiseren (scouting, zorg, reizen, etc.) } \\
\text { V16_8 afval van anderen in de natuur } \\
\text { opruimen } \\
\text { V16_9 anders, nl. } \\
\text { V16_10 geen van deze }\end{array}$ & $\begin{array}{l}\text { Aantal keren dat een activiteit } \\
\text { is genoemd opgeteld. } \\
\text { Variabele: beschermact } \\
\text { Values: } 1=\text { niets ( } 0 \\
\text { activiteiten), } 2=\text { weinig ( } 1 \\
\text { activiteit), } 3=\text { redelijk wat ( } 2 \\
\text { tot } 3 \text { activiteiten), } 4=\text { (zeer) } \\
\text { veel ( } 4 \text { activiteiten of meer) }\end{array}$ \\
\hline & $\begin{array}{l}\text { Soort betrokken- } \\
\text { heid bij burger- } \\
\text { initiatief }\end{array}$ & $\begin{array}{l}\text { V19_3 ik werk mee aan de uitvoering van } \\
\text { het initiatief } \\
\text { Values } 0=\text { not mentioned, } 1=\text { mentioned }\end{array}$ & $\begin{array}{l}\text { Aantal keren dat activiteit is } \\
\text { genoemd opgeteld en } \\
\text { toegevoegd aan activiteiten } \\
\text { voor natuur- en landschap. }\end{array}$ \\
\hline
\end{tabular}




\begin{tabular}{|c|c|c|c|}
\hline & $\begin{array}{l}\text { Betrokkenheid } \\
\text { bij natuur }\end{array}$ & Variabele naam en values & Bewerking \\
\hline \multirow[t]{2}{*}{$\begin{array}{l}\text { Beschermer } \\
\text { passief }\end{array}$} & Lidmaatschap & $\begin{array}{l}\text { V07_1 geen lid } \\
\text { V07_2 lid van Natuurmonumenten } \\
\text { V07_3 lid van Provinciale Landschappen } \\
\text { V07_4 lid van Wereldnatuurfonds } \\
\text { V07_5 lid van Greenpeace } \\
\text { V07_6 lid van andere organisatie }\end{array}$ & $\begin{array}{l}\text { Gehercodeerd tot lid of geen } \\
\text { lid en toegevoegd aan } \\
\text { financiële bijdrage aan } \\
\text { natuurbescherming }\end{array}$ \\
\hline & $\begin{array}{l}\text { Financiële } \\
\text { bijdrage aan } \\
\text { natuur- } \\
\text { bescherming }\end{array}$ & $\begin{array}{l}\text { V180_1 een extra bedrag geven voor } \\
\text { natuurbescherming } \\
\text { V180_2 groen belegd } \\
\text { V180_3 producten gekocht die rekening } \\
\text { houden met natuur (ecokeurmerk, FSC-hout, } \\
\text { duurzaam katoen, weidevogelmelk, etc.) } \\
\text { V180_4 aan een adoptieactie meegedaan } \\
\text { (kip, kalf, koe, akkerrand, bom, etc.) } \\
\text { V180_5 een certificaat voor bosaanplant } \\
\text { aangekocht ter compensatie van de uitstoot } \\
\text { van broeikasgassen door vliegreizen (via } \\
\text { Green Seat, etc.) } \\
\text { V180_6 anders, nl. } \\
\text { V180_7 geen van deze } \\
\text { Values } 0 \text { = not mentioned, } 1=\text { mentioned }\end{array}$ & $\begin{array}{l}\text { Aantal keren dat een activiteit } \\
\text { is genoemd opgeteld. } \\
\text { Variabele: finbijdrage } \\
\text { Values: } 1=\text { niets ( } 0 \\
\text { activiteiten), } 2=\text { weinig ( } 1 \\
\text { activiteit), } 3=\text { redelijk wat ( } 2 \\
\text { tot } 3 \text { activiteiten), } 4=\text { (zeer) } \\
\text { veel ( } 4 \text { activiteiten of meer) }\end{array}$ \\
\hline \multirow[t]{2}{*}{$\begin{array}{l}\text { Beslisser } \\
\text { actief }\end{array}$} & $\begin{array}{l}\text { Activiteiten } \\
\text { gericht op } \\
\text { beïnvloeding } \\
\text { besluitvorming }\end{array}$ & $\begin{array}{l}\text { V230_1 buurtoverleg over groenbeheer } \\
\text { bijgewoond } \\
\text { V230_2 actie gevoerd voor meer natuur of } \\
\text { behoud van natuur } \\
\text { V230_3 naar inspraak- of informatieavond } \\
\text { over natuur geweest } \\
\text { V230_4 brieven of opiniestukken geschreven } \\
\text { over de natuur } \\
\text { V230_6 protestmail gestuurd over de natuur } \\
\text { V230_7 anders, nl. } \\
\text { V230_8 geen van deze } \\
\text { Values: } 0 \text { = not mentioned, } 1=\text { mentioned }\end{array}$ & $\begin{array}{l}\text { Aantal keren dat een activiteit } \\
\text { is genoemd opgeteld. } \\
\text { Variabele: beslisact } \\
\text { Values: } 1=\text { niets ( } 0 \\
\text { activiteiten), } 2=\text { weinig ( } 1 \\
\text { activiteit), } 3=\text { redelijk wat ( } 2 \\
\text { tot } 3 \text { activiteiten), } 4=\text { (zeer) } \\
\text { veel ( } 4 \text { activiteiten of meer) }\end{array}$ \\
\hline & $\begin{array}{l}\text { Soort betrokken- } \\
\text { heid bij burger- } \\
\text { initiatief }\end{array}$ & $\begin{array}{l}\text { V19_1 Ik ben (één van de) initiatiefnemer(s) } \\
\text { Values } 0=\text { not mentioned, } \\
\text { 1=mentioned }\end{array}$ & $\begin{array}{l}\text { Aantal keren dat activiteit is } \\
\text { genoemd opgeteld en } \\
\text { toegevoegd aan activiteiten } \\
\text { gericht op beïnvloeding } \\
\text { besluitvorming }\end{array}$ \\
\hline $\begin{array}{l}\text { Beslisser } \\
\text { passief }\end{array}$ & $\begin{array}{l}\text { Activiteiten } \\
\text { gericht op } \\
\text { beïnvloeding } \\
\text { besluitvorming }\end{array}$ & $\begin{array}{l}\text { V230_5 handtekening gezet voor de natuur } \\
\text { V230_9 in mijn stemkeuze het onderwerp } \\
\text { natuur mee laten wegen } \\
\text { Values } 0 \text { = not mentioned, } \\
1=\text { mentioned }\end{array}$ & $\begin{array}{l}\text { Aantal keren dat een activiteit } \\
\text { is genoemd opgeteld. } \\
\text { Variabele: beslispas } \\
\text { Values: } 1=\text { niets ( } 0 \\
\text { activiteiten), } 2=\text { weinig ( } 1 \\
\text { activiteit), } 3=\text { redelijk wat ( } 2 \\
\text { activiteiten) }\end{array}$ \\
\hline
\end{tabular}

\section{Stap 3}

In stap 3 is een segmentering van burgers gemaakt op grond van de scores op de 6 indicatoren van betrokkenheid:

1. Weinig/niet betrokken: $6 x$ score 1 of 2 op de 6 indicatoren van betrokkenheid

2. Matig betrokken: hetzij $4 x$ score 1 of 2 en $2 x$ score 3 of 4 , hetzij $5 x$ score 1 of 2 en 1 x score 3 of 4 op de 6 indicatoren van betrokkenheid

3. Redelijk betrokken: $3 x$ score 1 of 2 en $3 x$ score 3 of 4 op de 6 indicatoren van betrokkenheid

4. Zeer betrokken: tenminste $4 x$ score 3 of 4 op de 6 indicatoren van betrokkenheid 


\section{Verschenen documenten in de reeks Technical reports van de Wettelijke Onderzoekstaken Natuur}

\& Milieu vanaf 2016

WOt-technical reports zijn verkrijgbaar bij het secretariaat van Unit Wettelijke Onderzoekstaken Natuur \& Milieu te Wageningen. T 0317 - 4854 71; E info.wnm@wur.nl

WOt-technical reports zijn ook te downloaden via de website www.wur.nl/wotnaturenmilieu

61 Berg, F. van den, A. Tiktak, J.J.T.I. Boesten \& A.M.A. van der Linden (2016). PEARL model for pesticide behaviour and emissions in soil-plant systems; Description of processes

62 Kuiters, A.T., G.A. de Groot, D.R. Lammertsma, H.A.H. Jansman \& J. Bovenschen (2016). Genetische monitoring van de Nederlandse otterpopulatie; Ontwikkeling van populatieomvang en genetische status $2014 / 2015$

63 Smits, M.J.W., C.M. van der Heide, H. Dagevos, T. Selnes \& C.M. Goossen (2016). Natuurinclusief ondernemen: van koplopers naar mainstreaming?

64 Pouwels, P. , M. van Eupen, M.H.C. van Adrichem, B. de Knegt \& J.G.M. van der Greft (2016). MetaNatuurplanner v2.0. Status $A$

65 Broekmeyer, M.E.A. \& M.E. Sanders (2016). Natuurwetgeving en het omgevingsrecht. Achtergrond-document bij Balans van de Leefomgeving, 2014

66 Os, J. van, J. H.S.D. Naeff \& L.J.J. Jeurissen (2016).Geografisch informatiesysteem voor de emissieregistratie van landbouwbedrijven; GIABplus-bestand 2013 - Status A

67 Ingram, V.J., L.O. Judge, M. Luskova, S. van Berkum \& J. van den Berg (2016). Upscaling sustainability initiatives in international commodity chains; Examples from cocoa, coffee and soy value chains in the Netherlands.

68 Duin van W.E., H. Jongerius, A. Nicolai, J.J. Jongsma, A. Hendriks \& C. Sonneveld (2016). Friese en Groninger kwelderwerken: Monitoring en beheer 1960-2014.

69 Ehlert, P.A.I., T.A. van Dijk \& O. Oenema (2016). Opname van struviet als categorie in het Uitvoeringsbes/uit Meststoffenwet. Advies.

70 Ehlert, P.A.I., H.J. van Wijnen, J. Struijs, T.A. van Dijk, L. van Schöll, L.R.M. de Poorter (2016). Risicobeoordeling van contaminanten in afval- en reststoffen bestemd voor gebruik als covergistingsmateriaal

71 Commissie Deskundigen Meststoffenwet (2016). Protocol beoordeling stoffen Meststoffenwet. Versie 3.2

72 Kramer, H., J. Clement (2016). Basiskaart Natuur 2009. Een landsdekkend basisbestand voor de terrestrische natuur in Nederland

73 Dam, R.I. van, T.J.M. Mattijssen, J. Vader, A.E. Buijs \& J.L.M. Donders (2016). De betekenis van groene zelf-governance. Analyse van

\begin{tabular}{|c|c|}
\hline & $\begin{array}{l}\text { verschillende vormen van dynamiek in de } \\
\text { praktijk. }\end{array}$ \\
\hline 74 & $\begin{array}{l}\text { Hennekens, S.M., M. Boss \& A.M. Schmidt (2016). } \\
\text { Landelijke Vegetatie Databank; Technische } \\
\text { documentatie, Status A }\end{array}$ \\
\hline 75 & $\begin{array}{c}\text { Knegt, B. de, et al. (2016). Kansenkaarten voor } \\
\text { duurzaam benutten van Natuurlijk Kapitaal }\end{array}$ \\
\hline 76 & $\begin{array}{c}\text { Commissie Deskundigen Meststoffenwet (2016). } \\
\text { Advies 'Mestverwerkingspercentages 2017' }\end{array}$ \\
\hline 77 & $\begin{array}{l}\text { W.H.J. Beltman, C. Vink \& A. Poot (2016). } \\
\text { Calculation of exposure concentrations for NL } \\
\text { standard scenarios by the TOXSWA model; Use } \\
\text { of FOCUS_TOXSWA } 4.4 .3 \text { software for plant } \\
\text { protection products and their metabolites in } \\
\text { Dutch risk assessment for aquatic ecosystems }\end{array}$ \\
\hline 78 & $\begin{array}{l}\text { Koffijberg K., J.S.M. Cremer, P. de Boer, J. Postma } \\
\text { \& K. Oosterbeek \& J.S.M. Cremer (2016). } \\
\text { Broedsucces van kustbroedvogels in de } \\
\text { Waddenzee in } 2014 .\end{array}$ \\
\hline 79 & $\begin{array}{l}\text { Sanders, M.E. G.W.W Wamelink, R.M.A. Wegman \& } \\
\text { J. Clement (2016). Voortgang realisatie } \\
\text { nationaal natuurbeleid; Technische } \\
\text { achtergronden van een aantal indicatoren uit de } \\
\text { digitale Balans van de Leefomgeving } 2016 .\end{array}$ \\
\hline 80 & $\begin{array}{l}\text { Vries, S. de \& I.G. Staritsky (2016). AVANAR } 2.0 \\
\text { nader beschreven en toegelicht; } \\
\text { Achtergronddocumentatie voor Status } A .\end{array}$ \\
\hline 81 & $\begin{array}{l}\text { Kuiters, A.T., G.A. de Groot, D.R. Lammertsma, } \\
\text { H.A.H. Jansman \& J. Bovenschen (2016). } \\
\text { Genetische monitoring van de Nederlandse } \\
\text { otterpopulatie; Ontwikkeling van } \\
\text { populatieomvang en genetische status 2015/ } \\
2016 .\end{array}$ \\
\hline 82 & $\begin{array}{l}\text { Pleijte, M., R. Beunen \& R. During (2016). } \\
\text { Rijksprojecten: hét natuurinclusieve werken? } \\
\text { Een analyse van relaties tussen rijksprojecten en } \\
\text { de Rijksnatuurvisie }\end{array}$ \\
\hline 83 & $\begin{array}{l}\text { Smits, M.J.W. en E.J. Bos (2016). Het stimuleren } \\
\text { van ondernemen met natuur: handelingsopties } \\
\text { voor de overheid }\end{array}$ \\
\hline 84 & $\begin{array}{l}\text { Horst, M.M.S. ter, W.H.J. Beltman \& F. van den } \\
\text { Berg (2016). The TOXSWA model version } 3.3 \text { for } \\
\text { pesticide behaviour in small surface waters; } \\
\text { Description of processes }\end{array}$ \\
\hline 85 & $\begin{array}{l}\text { Mattijssen, T.J.M. (2016). Ideaaltypen en } \\
\text { analysekader van groene burgerinitiatieven; } \\
\text { Bijlage bij het rapport 'De betekenis van groene } \\
\text { burgerinitiatieven: analyse van kenmerken en } \\
\text { effecten van } 264 \text { initiatieven in Nederland' }\end{array}$ \\
\hline 86 & $\begin{array}{c}\text { Wösten, J.H.M., F. de Vries \& J.G. Wesseling } \\
\text { (2016). BOFEK2012 versie 2; Status } A\end{array}$ \\
\hline
\end{tabular}


87 Pleijte, M., R. During \& R. Michels (2016). Nationale parken in transitie; governance-implicaties van een veranderend beleidskader

88 Mol-Dijkstra, J.P.\& G.J Reinds (2017). Technical documentation of the soil model VSD+; Status A

89 Arets, E.J.M.M., J.W.H van der Kolk, G.M. Hengeveld, J.P. Lesschen, H. Kramer, P.J. Kuikman \& M.J. Schelhaas (2017). Greenhouse gas reporting for the LULUCF sector in the Netherlands. Methodological background, update 2016

90 Bruggen, C. van, A. Bannink, C.M. Groenestein, J.F.M. Huijsmans, H.H. Luesink, S.V. Oude Voshaar, S.M. van der Sluis, G.L. Velthof \& J. Vonk (2017). Emissies naar lucht uit de landbouw in 2014. Berekeningen met het model NEMA

91 Os van, J., M.G.T.M. Bartholomeus, L.J.J. Jeurissen \& C.G. van Reenen (2017). Rekenregels rundvee voor de landbouwtelling. Verantwoording van het gebruik van I\&R gegevens voor de landbouwtelling

92 Haas, W. de, R.J. Fontein \& M. Pleijte (2017). Is eenvoudig beter? Twee essays natuur en landschap in het nieuwe omgevingsbeleid

93 Schuiling, C., A.M. Schmidt, I.J. La Rivière \& R.A. Smidt (2017). Beschermde gebiedenregister; Technische documentatie, Status A.

94 Henkens, R.J.H.G., M.M.P. van Oorschot en J. Ganzevles (2017). Bijdrage van Green Deals aan de beleidsdoelen voor natuur en biodiversiteit

95 Arets, E.J.M.M., J.W.H van der Kolk, G.M. Hengeveld, J.P. Lesschen, H. Kramer, P.J. Kuikman \& M.J. Schelhaas (2017). Greenhouse gas reporting for the LULUCF sector in the Netherlands. Methodological background, update 2017

96 IJsseldijk, L.L., M.J.L. Kik, L. Solé \& A. Gröne (2017). Postmortaal onderzoek van bruinvissen (Phocoena phocoena) uit Nederlandse wateren, 2016.

97 Verburg, R.W., W.H.G.J. Hennen, L.F. Puister, R. Michels \& K. van Duijvendijk (2017). Estimating costs of nature management in the European Union; Exploration modelling for PBL's Nature Outlook

98 Bruggen, C. van, A. Bannink, C.M. Groenestein, J.F.M. Huijsmans, H.H. Luesink, S.V. Oude Voshaar, S.M. van der Sluis, G.L. Velthof \& J. Vonk (2017). Emissies naar lucht uit de landbouw in 2015. Berekeningen met het model NEMA

99 Kuiters, A.T., G.A. de Groot, D.R. Lammertsma H.A.H. Jansman \& J. Bovenschen (2017). Genetische monitoring van de Nederlandse otterpopulatie; Ontwikkeling van populatieomvang en genetische status $2016 / 2017$
100 Adriaanse, P.I. \& W.H.J Beltman (2017) Comparison of pesticide concentrations at drinking water abstraction points in The Netherlands simulated by DROPLET version 1.2 and 2.0

101 Daamen, W.P., A.P.P.M. Clerkx \& M.J. Schelhaas (2017). Veldinstructie Zevende Nederlandse Bosinventarisatie (2017-2021)

102 Boer, T.A. de \& F.L. Langers (2017). Maatschappelijk draagvlak voor natuurbeleid en betrokkenheid bij natuur in 2017

103 Buijs, A.E., B.H.M. Elands \& C.S.A. van Koppen (2017) 25 jaar burgerbetrokkenheid in het natuurbeleid. Analyse van beleidsdiscoursen en publiek draagvlak

104 Cremer, J.S.M., S.M.J.M. Brasseur., A. Meijboom, J. Schop \& J.P. Verdaat (2017). Monitoring van gewone en grijze zeehonden in de Nederlandse Waddenzee, 2002-2017

105 Glorius, S.T., A. Meijboom, J.T. van der Wal \& J.S.M. Cremer (2017). Ontwikkeling van enkele mosselbanken in de Nederlandse Waddenzee, situatie 2016

106 Hennekens, S.M., W.A. Ozinga \& J.H.J. Schaminée (2017). BioScore 3 - Plants. Background and pre-processing of distribution data

107 Melman, Th.C.P., M.H.C. van Adrichem, M. Broekmeyer, J. Clement, R. Jochem, H.A.M. Meeuwsen, F.G.W.A. Ottburg, A.G.M. Schotman \& T. Visser (2017). Bijdrage natuurcombinaties aan landelijke natuurdoelstelling buiten NNN; Verkenning van een methodiek, gebaseerd op ecologische modellen

109 Overbeek, M.M.M., E. Smeets \& D. Verhoog (2017). Biobased materialen, circulaire economie en natuurlijk kapitaal. 



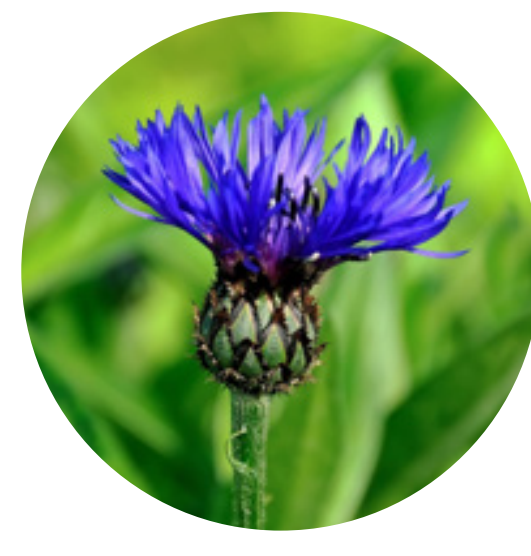

Thema Periodieke Evaluatie

Natuurbeleid

Wettelijke Onderzoekstaken Natuur \& Milieu

P.O. Box 47

6700 AA Wageningen

T (0317) 485471

E info.wnm@wur.nl

ISSN 2352-2739

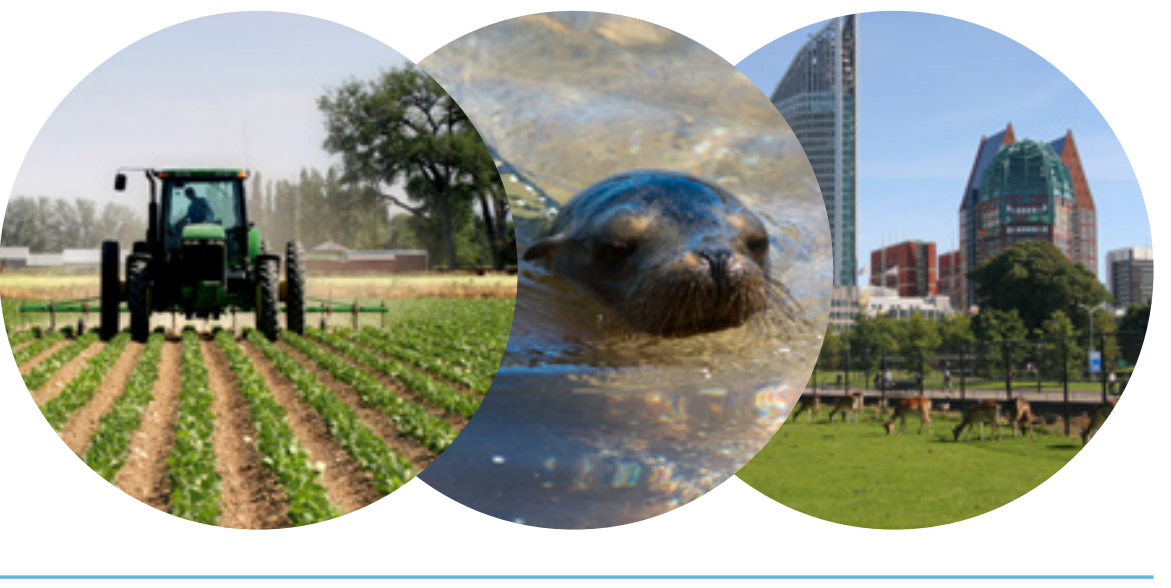

De missie van Wageningen University \& Research is 'To explore the potential of nature to improve the quality of life'. Binnen Wageningen University \& Research bundelen 9 gespecialiseerde onderzoeksinstituten van Stichting Wageningen Research en Wageningen University hun krachten om bij te dragen aan de oplossing van belangrijke vragen in het domein van gezonde voeding en leefomgeving. Met ongeveer 30 vestigingen, 5.000 medewerkers en 10.000 studenten behoort Wageningen University \& Research wereldwijd tot de aansprekende kennisinstellingen binnen haar domein. De integrale benadering van de vraagstukken en de samenwerking tussen verschillende disciplines vormen het hart van de unieke Wageningen aanpak. 